Historic, Archive Document

Do not assume content reflects current scientific knowledge, policies, or practices. 

(6) United States

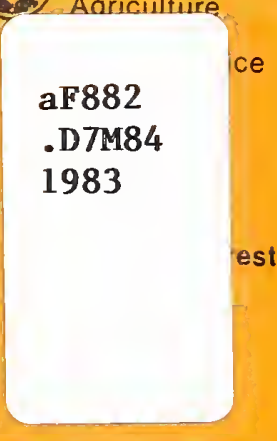

Norman A. Myers

Letters to Home:

Life in C.C.C. Camps

Douglas County, Oregon

Norman A. Myers

Edited by Gerald W. Williams

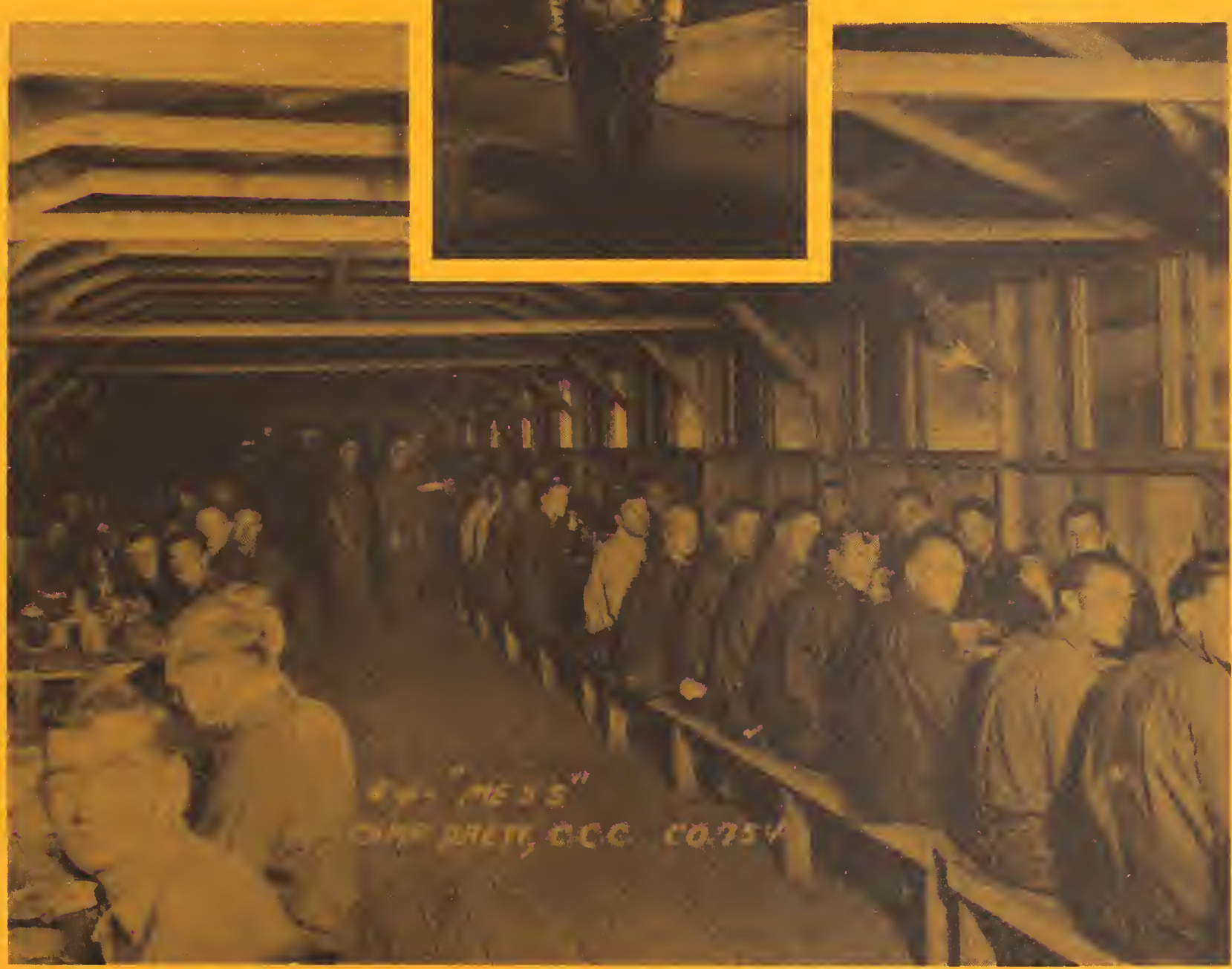


United States

Department of

Agriculture

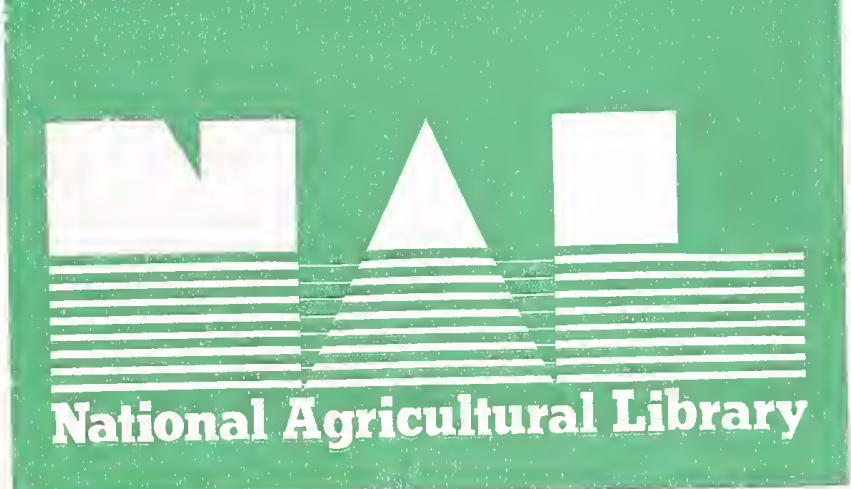




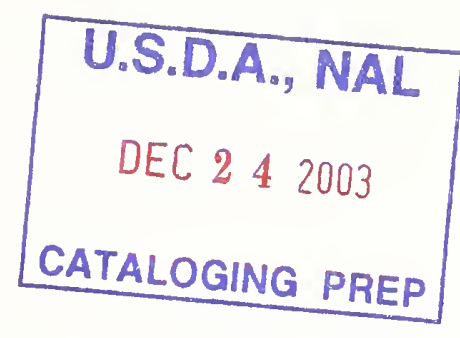

LETTERS TO HOME: LIFE IN C.C.C. CAMPS OF DOUGLAS COUNTY, OREGON 1933-1934

\author{
By \\ Norman A. Myers \\ Post Office Inspector (Retired) \\ Former Civilian Conservation Corps Enrollee
}

Edited By

Gerald W. Williams. Ph.D.

Sociologist and Social Historian

\author{
USDA-Forest Service \\ Umpqua National Forest \\ Roseburg, Oregon
}


TABLE OF CONTENTS

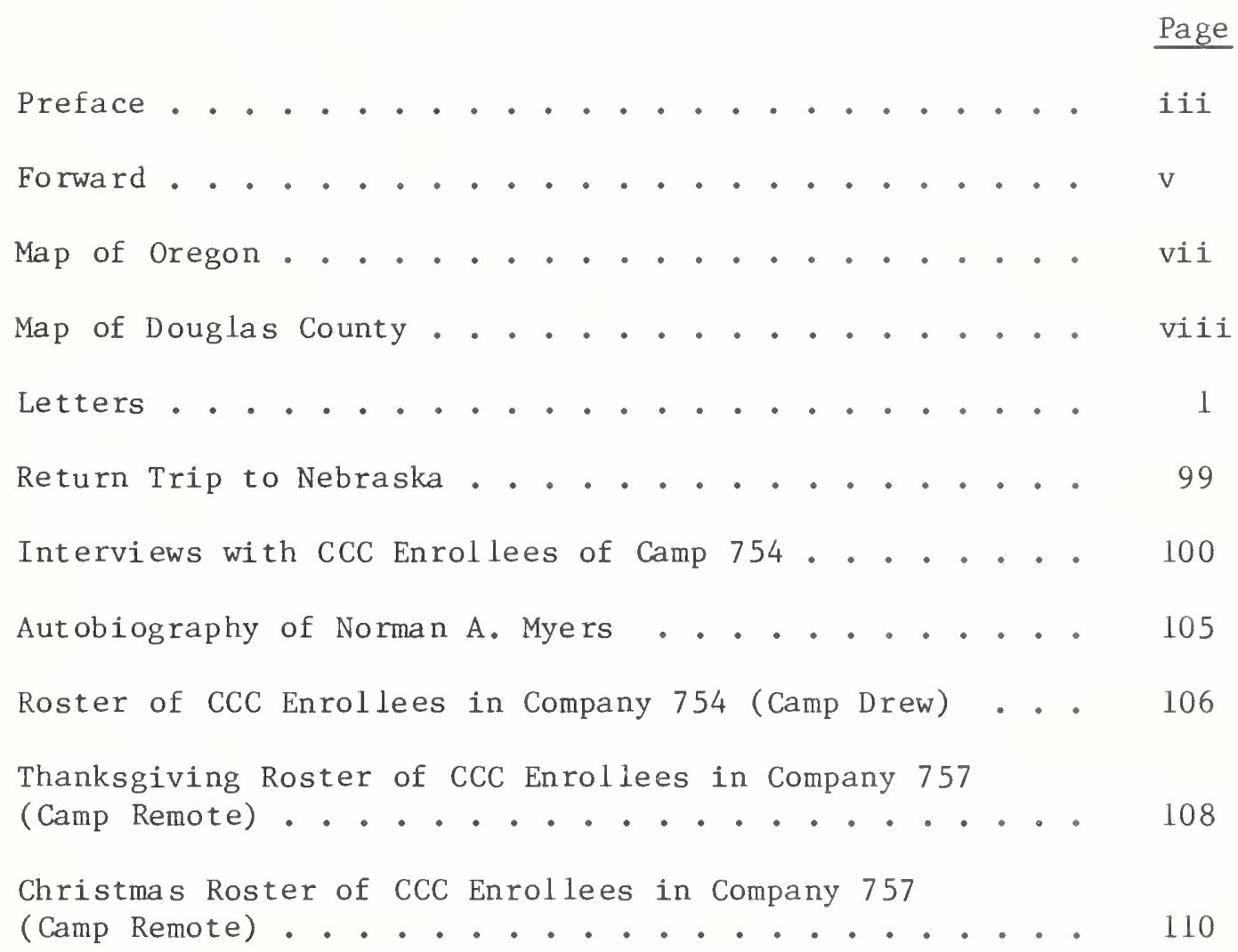



PREFACE

In the early $1930^{\prime} \mathrm{s}$, the United States was at the bottom of its greatest economic depression. Our nation began the Great Depression with the "crash" of the stock market in 1929. Almost four years later, the economic conditions were even worse. Tens of millions of Americans were out of work, banks were collapsing, and businesses were closing everywhere. People had nothing to do, nowhere to go, and were of ten feeling hungry, bewildered, apathetic, and sometimes angry. Young people were especially hard hit as they were untrained, unskilled, unable to gain work experience, and of ten without an adequate education. But worst of all, they had little hope for the future.

President Franklin Delano Roosevelt's inaugural speech on March 20, 1933, helped to change that defeatist attitude to one of careful optimism. He created a host of new Federal agencies, including the Civilian Conservation Corps (CCC), to start the country on the road to recovery. The CCC program became one of the most successful of the back to work programs of the New Deal.

President Roosevelt signed Executive Order No. 6101 on April 5, 1933, officially establishing the CCC. Selection of men for the CCC camps began on April 7, 1933, with the first organized camp established 10 days later near Luray, Virginia. Appropriately, it was named Camp Roosevelt. By June, an average of 8,500 men a day were selected and assigned to CCC camps around the nation.

The CCC program had two main objectives. The most important was to find useful conservation work for millions of unemployed young men. The other objective was to provide vocational skills, and later educational training, for the men through conservation work.

The CCC enrolleees were paid $\$ 30$ a month, of which $\$ 25$ was sent directly to their families back home. In the Forest Service CCC camps, they were under the direction of professional foresters during the day and the Army at night. The enrollment, which was entirely voluntary, lasted six months, with the option of reenrolling for another six months.

In Oregon, the first CCC camps, including several in Douglas County, were established in June 1933. Generally, the permanent camps were organized with around 200 men, with temporary work or "side" camps used during the summer months on specific work projects. As the CCC men were assigned forest-related conservation work, most of the CCC camps in Douglas County were established in the National Forests and adjacent Public Domain land, later to be combined into the Bureau of Land Management. As the CCC program grew, other federal, state, county, and even a few private forests had camps or projects.

Norman Myers was a member of one of the first CCC camps in Douglas County. His original CCC Company 754 from Nebraska was assigned to a camp location at Drew, near Tiller, Oregon, in the summer of 1933. His second CCC Company 757 was assigned to Camp Remote in Camas Valley, west of Roseburg, Oregon. Both companies were under the direction of forest officers from the Umpqua National Forest, headquartered in Roseburg.

The Myers letters were mailed to his family at home in Fremont, Nebraska. He wrote about two times per week for the ten months of his CCC enrollment during 
1933-34. These letters, unbeknowst to Mr. Myers, were stored by his parents for half a century. Recently, he discovered the letters in his parents' home. Mr. Myers has graciously allowed the Umpqua National Forest to copy and edit his letters for the golden anniversary of the founding of the Civilian Conservation Corps.

The Myers letters eloquently speak of the Depression Era and the CCC program. The candid letters, with very little edfting, allow a unique glimpse into the life of a CCC enrollee. The letters also record an almost daily diary of a young man from Nebraska. The personal growth, the learning of several new trades making new friends, and being so far away fron home are recorded in the letters.

The letters also show his great concern for his parents and family. As Mx. Myers states in his autobiography, which follows the letters in this publication, the money from his CCC wages was sent home to his family and it enabled them to survive the worst of the Great Depression. By the end of his two enrollments, the letters show Norman Myers emerging as a skilled and confident man, capable of finding and holding a job, even in the midst of the Depression. These letters and his life are a tribute to the 50 th Anniversary of the founding of the CCC.

June 30,1983

Gerald W. Williams, Ph.D. Sociologist and Social Historian Umpqua National Forest 
FORWARD

The initial organization for the Civilian Conservation Corps in Nebraska began during mid-April, 1933, with the division of the State into 16 sectors. Sector Seven consisted of Dodge, Saunders, Colfax, Cuming and Burt Counties. Nebraska State Tax Commissioner $W$. H. Smith was in charge of the selection of Nebraska's quota of CCC enrollees. Dodge County had a quota of 49 men, Saunders 39, Colfax 22, Cuming 27, and Burt 25, making a total of 162 members from our sector.

The first definite information about this program was received in Dodge County, where I lived, about April 28, 1933. A Selection Committee was quickly organized in Dodge County with N. H. Mapes, an Attorney, as Chairman. Other members of this Committee were Frank Perkins, who later became Postmaster; County Supervisor Swan Anderson; County Assessor A. 0. Swartwood; and Attorney Eugene L. Mahlin. Since time was limited, they worked all day and through the evening on Saturday, April 29th, and returned on Sunday, April 30th, to complete the selection. A total of 110 men in Dodge County applied for enrollment in the CCC and this Selection Committee found exactly 100 met all requirements for the Corps. The principal consideration used in this selection was need. Only single men between the ages of 18 and 25 who had dependents were eligible. Names of those selected were published in the May 1, 1933, issue of the Fremont Tribune. On the same date a list of those selected was forwarded to W. H. Smith in Lincoln.

For about two weeks no further information about the Service was received in Fremont. At 5:30 p.m. on May 15th, Chairman N. H. Mapts was advised that a physical examination for the CCC applicants would start at 11:00 the following day. The physicals were to be held at the Dodge County Courthouse for all 162 youths from the Seventh Nebraska Sector.

This short notice forced Mapes to make a hurried roundup of the members of the Dodge County quota. By working until late that night, either by telephone or automobile, he communicated with every man selected or his family. As usual, I had spent the night fishing from a small boat in the lakes west of town and did not know about the scheduled leaving until returning home about daylight.

The physical examinations were given under the direction of Major Philpot of the U.S. Army. Due to the early arrival of most men the physicals were started during the mid-morning hours. Only three of the 162 men could not be enrolled. At the same time of the examinations, a rather large number of men who had not been selected for the CCC Service gathered at the Courthouse in order that they might be considered for any vacancies caused by men who could not go. The physical exam processing was completed by early afternoon.

The men left Fremont on the 2:30 p.m. Union Pacific train for Fort Crook. The site of this fort was 10 miles south from Omaha, Nebraska, and currently is occupied by Offutt Air Force Base. A transfer was made at the Omaha Union Station to a Missouri Pacific passenger train with an arrival at the fort about 5:30 p.m. Military personnel marched us from the depot to the CCC tent area. Our group was officially in the Civilian Conservation Corps. 
In reading the historic files of the Fremont Tribune, an impressive display of public spirit was recorded. Local officials helped put this important program into effect, even though they worked many long hours without pay. Obviously. they understood the seriousness of the Depression and the opportunity that the CCC program held for these young men. Of course, a great amount of credit is also due to the large number of able-bodied men who were willing to take a job paying but $\$ 5.00$ a month with room and board, while $\$ 25.00$ was sent home to their dependents. The men who traveled to far away places to do needed work, receive some pay, and assist their dependents survive during the economic disaster will be remembered for many years.

Fremont, Nebraska

Norman A. Myers

March 21, 1983 


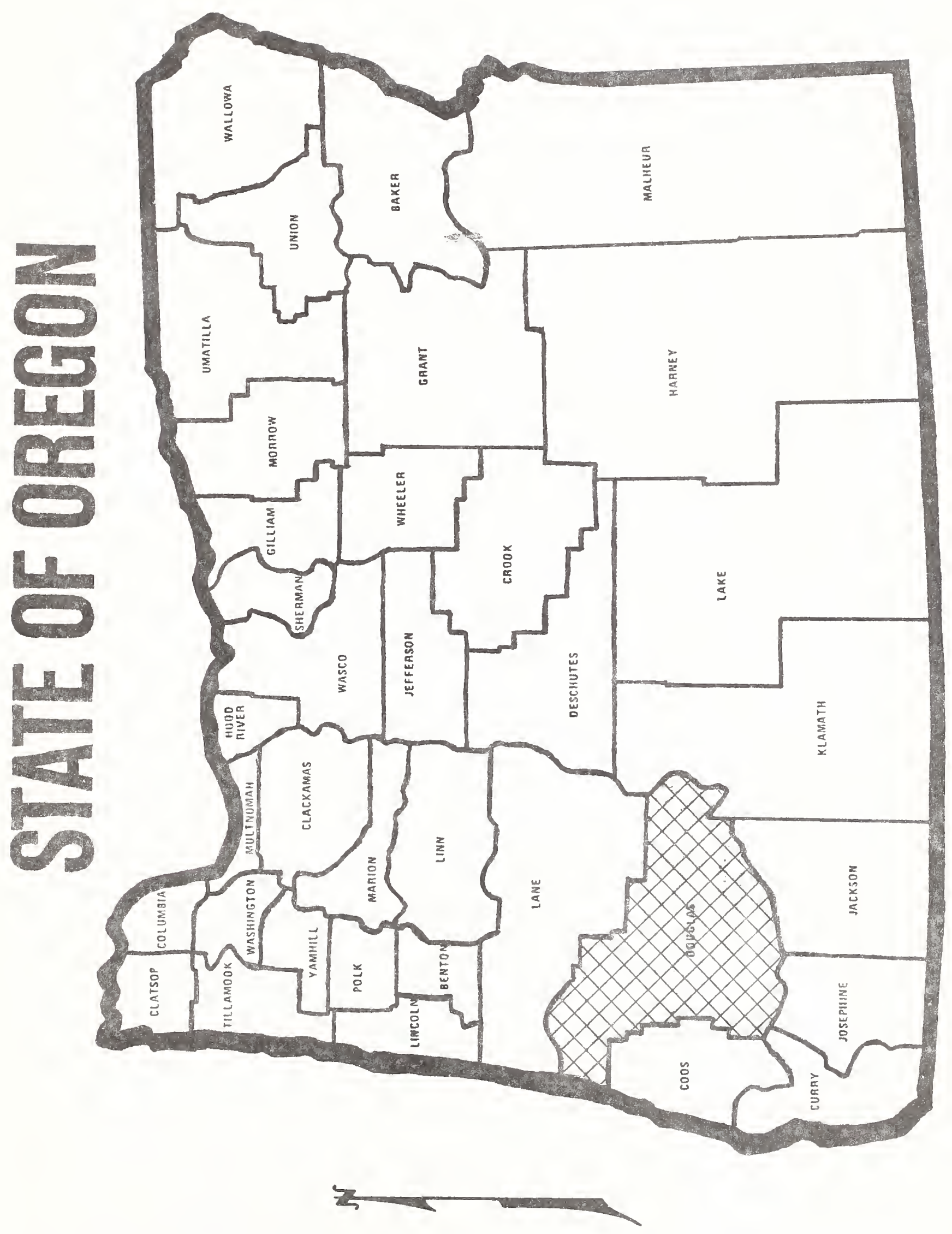




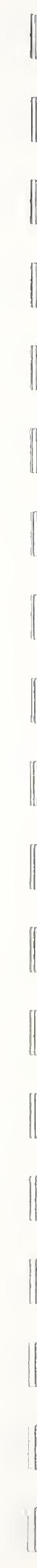




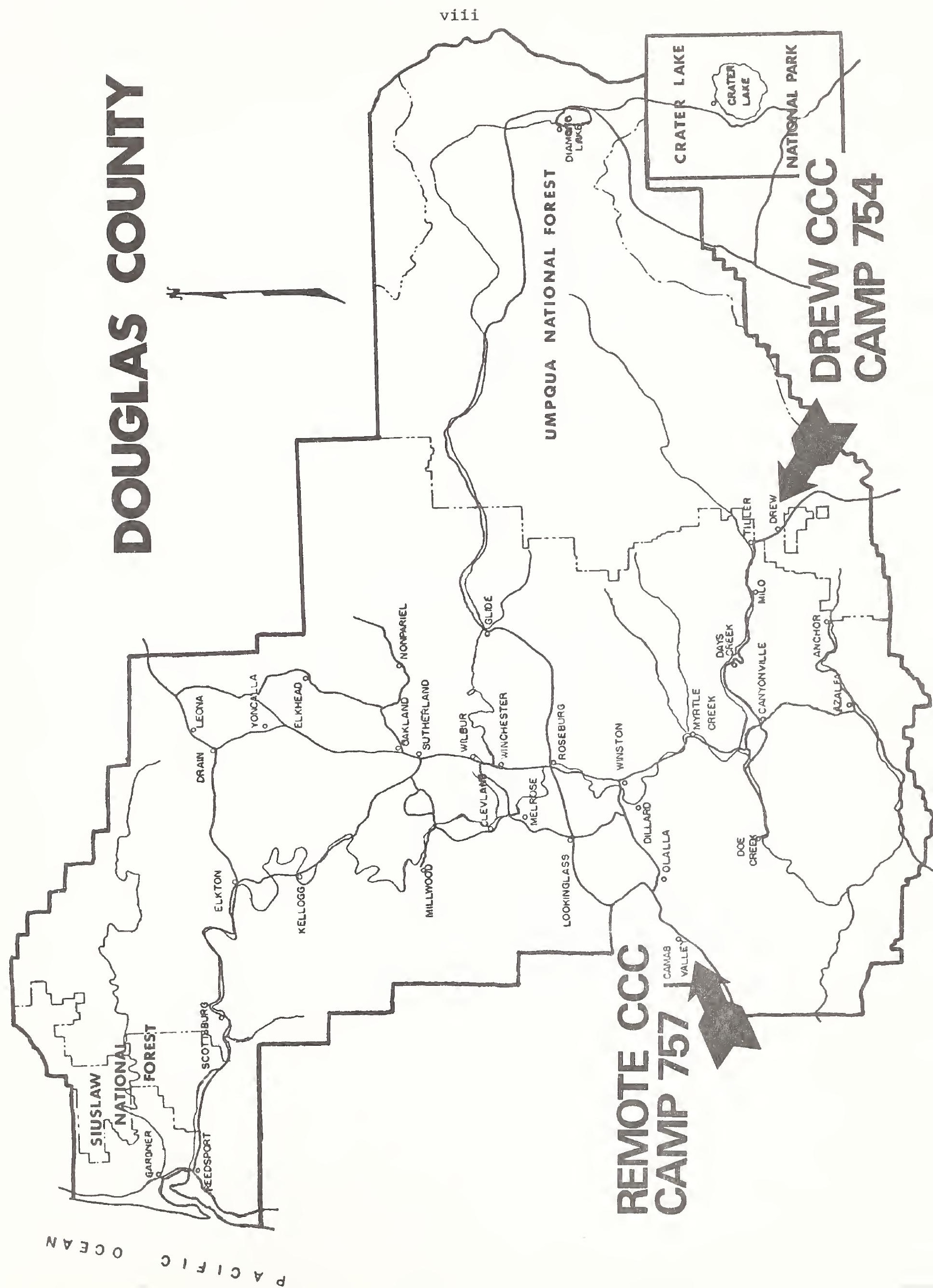


LETTERS TO HOME 
\|\|
$\|$

$\|$

$\|$

$\|$

II 
Fort Crook, Nebr.

Wednesday, May 17, 1933

Dear Folks:

I sure feel like hell now. Got a physical exam this morning and passed. Got two vaccinations and it is a tough one for typhoid. Got my clothes this morning. Gave us 6 pr. of socks, 1 pair shoes, 3 of underwear, 1 dress suit, 3 work suits, necktie and cap. They also furnish 1 gillette razor [and blades], shaving cream, toothpaste, toothbrush, soap and all essentials.

We have not had to work yet but will have to soon. The first [Civilian Conservation Corps - CCC] outfit is still working here but will leave soon. They are sure pouring in now. There will be 1,800 in soon. They don't know where they are going either.

It is surely windy today. I think it will storm. There is a ball game going today. Well this is all I know now. I don't know when it is best to come down but I don't need anything but maybe [basebal1] spikes.

C.C.C. Company 754

Norman

Fort Crook, Nebr.

oh I'll write again soon.

Thursday

May 18,1933

Dear Folks. I feel a lot better today. They are surely putting up tents now. Every train brings in a couple hundred [new CCC enrollees]. If you want to come it is all right but women are not allowed. Too many naked men. They furnish anything about that you need. Bring my poor spikes when you come. They will hook anything good. Will get a furlough one of the weekends.

Norman

Fort Crook, Nebr.

Friday, May 19, 1933

Dear Folks:- We are all getting better now. The grub was good today. No mail for me though. We are still eating at the dining hall. All others are eating in a soup kitchen outside. I will not get off this weekend. I am going home next weekend. None of the men have left yet but they promise to take them every day. They are coming in every day. No work yet. Don't think they give much [work] here as there are more men than jobs. 
Fort Crook, Nebr.

May 22, 1933

Dear Folks:-

It surely rained hard last night. We were just checking in for the night when it came up. The tent never leaked a bit. Eric Sinnett and Fritz- skinned out [left the Fort wi thout proper authorization - AWOL] last night and came back this morning. They were [not] caught though. You have to be in the tent from 11-5 every night. I don't think I will get home at all but will go to Omaha next Sunday.

None of the men have left camp yet but will leave soon. California wants 1,000 men. It is likely the Negro regiment will go to Spirit Lake, Iowa. Then there will be two to the Black hills, one to western Wyoming and our Lieutenant says one regiment will go to Crawford [Nebraska] and Lusk, Wyoming. This is supposed to be ours. They will work north out of Lusk or 17 miles southwest of Crawford.

The [Army CCC] officers are all good men to be with. They are helpful not tough. The food is good yet but may be poor for a while when the kids begin to cook. Several of the Omaha men have gone over the hill and five of the Sioux City men were gone one morning. Four of our men in the tent are visiting Fremont today via box car route [riding the empty railroad box cars]. The kids can tell you when all the freights run. Hitch hiking is forbidden.

The boys in the camp chipped in and subscribed to the Bee [Omaha, NE newspaper] this morning. It is the only paper delivered out to the C.C.C. Camp. We all have to make the beds every morning, sweep out the tent, and pick up the papers on the lawn. Our tent is making a collection of beer labels. There is a whoopee joint here but last night guards patroled the road in front of it with guns. They keep a few [Army Air Corps] planes here and every day they are up [flying].

Saw a bum bal1 game yesterday. The Fort [Crook] team 1ost 13-1. It looks like they would not play today even if the sun keeps shining. The officers claim the Omaha and Sioux City outfits are the hardest to handle.

I was sure glad to get your letter. Don't you think it is an honor for Uncle Frank 2 to be sued for $\$ 50,000[?]$. Not much doing now so will not write so often. Have plenty of money. Maybe you could come to Omaha next Sunday. I wi 11 be at Uncle Frank's.

Norman

1/ Walter Fritz from Fremont, Nebraska.

2/ My Uncle Frank was Frank Myers, the Police Commissioner of Omaha, Nebraska. He and his son Eldon were killed in an automobile accident in August of 1935. 
Ft. Crook, NE

Wednesday, May 23

Dear Folks -

We had our inoculation postponed [from] today until tomorrow. Didn't work today. Ball game in a few minutes. Got our mess kits today. Will come home next Sat. or Sunday. Will hike or ride a freight. A bunch are going. No military drills for us yet. Didn't get on K.P. duty yet. Its awful hot this p.m. Buy some peanut bars P.B. for me as they don't handle them in the canteen. My tentmates are Victor Soh1, Walter Otto, Leonard Le Grand, and Russel1 Redding all of Fremont [Nebraska]. Al Sloatman of Decatur, and Tom Tighe of Bancroft [Nebraska].

Got your letter and paper today. Washed out my clothes but didn't do much of a iob. I can write all I know on a postcard so it is economical. Reazd of the tornado at Tyron [Nebraska], How many fish did they catch at Hula's. - How is business at the station?

Norman

3/ Ed Hula, a friend, owned a farm along the Elkhorn River northeast from Fremont.

4/ My brother Emerson worked at the Firestone Tire and Rubber Company service station in Fremont.

Fort Crook, Nebr. May 30,1933

\section{Dear Folks:-}

We had to move our [CCC] camp today for some reason or other. We moved about one quarter of a mile northeast of the bus depot. The toilet facilities are poorer as we have no sewer. About a quarter of a mile northeast is the pretty village of Bellevue. Our personnel is changed somewhat as we have a larger tent with 12 beds instead of the eight we had in the other tent. The trucks moved all of the stuff except our grips. The high clay bluff of the Missouri rises above the level bottoms east of [the] camp. There is little timber on it. Just a little scrub timber in spots. We have no board floor now [in the tent]. The electricians are just putting in the light just now. The tents are on the north end of the airfield. The plane is up above the clouds now. A kid is playing (trying to) the accordian constantly now. It is certainly terrible music.

I sure feel fine now. We will get our next shot [innoculation] next Thursday. I won't have to work then or Wednesday afternoon. We are not working today. Monday we unloaded four more cars of asphalt. They sure are putting in the paving. I think they will finish all of it this week. They are going to run out of work for us soon. 
We got to Omaha at 6 o'clock Sunday afternoon. Uncle Frank drove through Arlington, Washington, and Bennington Sunday. You ought to drive down here that way sometime. We ran out of gas south of Washington. Had to get it at a farm house. The car just makes 14 miles on a gallon which is not much for a car with 6,000 miles. About 9 we started for the Fort but the 1ights wouldn't go on for the fuse had burned out [in the car]. We made two [fuses] to get out here. Uncle Frank wants Emerson to clean and oil the springfield and krag now as he thinks they should be fixed we 11 be $\overline{\text { fore }}$ they are let lay idle al1 summer. I am going into Omaha tomorrow if I can get off.

Has Emerson caught any more fish? I sure had the luck Sunday. It sure has been cold the last couple nights but it is hot today. We have to march to the mess hall a mile away now, but will have to eat out of our mess kits tomorrow noon and ever after. No one has left for the forest yet but they backed up a [Union Pacific] baggage car to the quartermaster yesterday. This looks like business to me. Had 21 shot salute with cannon this noon. I will be up to Frank's Sunday if possible. Come down if possible. Well this is all I have so will close now.

Norman

Fort Crook, Nebr. June 1, 1933

Dear Folks:-

Well we finally got started to eat out of our mess kits. Our first meal outside was Wed. noon. I didn't have to work yesterday but we marched about 25 miles today. The marching is 10 times harder than the work. Also we were al1 lined up today and got our pay at the mess ha11. Mine amounted to $\$ 2.33$ cents which is all I need till July first. "Red" Clark, a regular in the Army, is our chief cook. He is also owner of our mascot, a pet crow.

At 10 o'clock Wed. morning we were all lined up and got our last shot. It was nothing. Never made me either sick or gave me a sore arm. We have certainly been having fine weather. Had radishes for dinner the other day out of the Army gardens. The airplanes are flying all of the time. Big Army bombers, too. Tuesday night a kid smoked a cigarette in bed and in a short time the bed was on fire. It burned clear up before they could put it out. It will cost the kid $\$ 10$ out of his wages which is more than he can afford.

Last night 42 men out of companies 751-752 left for Sacramento, Calif. They will make camps for the rest of the companies. We don't know when we will leave or where we will go but the rumor is that we will still go to Calif. We cannot leave the camp this week and I think this looks like we might leave soon.

How are Joe, Red, and Swartz- 5 how. I hope you come down Sunday.

Norman

5/ Joe and Red were my brother's coon hounds and Swartz was the pet cat. All had been brought from the farm. 
Fort Crook, Nebr. June 7,1933

Dear Folks:-

I received ygur letter and the Tribune today. It was certainly pitiful about otis Button.- How did Mother, Ruth, and Emerson get home Sunday? I was certainly glad to see them. I would not have had to of gone into the camp till eleven that night but Sgt. told us to be back in the afternoon. I had to work all day Mon. It was rather hot and I drank too much water. Then I got off feed and didn't eat supper. I feel good now though. Worked on the rifle range Tuesday morning cutting weeds. They say that this was the last work at the Fort. In the afternoon we got canteens and dress coats in the quartermaster's building.

Last night after chow they called on twenty of our company to load our [railroad] cars and I was one. We loaded an entire baggage car in 1 hour. It contains provisions for 16 days. It was a Burlington [railroad] car and all of the goods is billed for Eugene, Oregon. We sure had to work hard and the boxes were heavy. I never realized that an express car was as big before. All the goods had been previously billed to Sacramento, Calif.

This noon 21 men from the camp left for Eugene to make the preliminary camp for us. We will leave sometime between Sat. \& Tues. They take the Burlington to Denver according to our officers. Then I don't know what. If we take the Burlington I will not send a telegram but if we take the U.P. [Union Pacific Railroad] I will send one. I see by the paper that we travel in Pullmans [railroad passenger cars]. Our camp sure gave the men who left this noon a roaring sendoff. The trip takes 3 days. Eugene is 60 miles from the Pacific. It is funny we didn't go to Sacramento but someone threw a wrench into it. I think I'll like Oregon better anyway.

They certainly gave the Omaha gang a real sendoff Mon. night. The band played "California, Here I Come," and a lot of other pieces. I suppose you read about it in the paper. I suppose you also read that you [the CCC men] can get $\$ 45$ or $\$ 36$ a month if you are promoted. I have not been so I think my $\$ 5$ a month [the remainder sent home] will be all I get. On the whole the thick headed dummies are the foremen. I am going to study a lot so I might get a raise later on if they see fit. We have a new Lieut. in charge as all of ours left for Oregon.

Everybody in camp has been looking at maps lately. There has been a lot of kidding about going to Fremont Lakes [Nebraska] too. I don't think a single soul in the camp cared to stick it out if they had to go there. I just figured out that it will cost $\$ 50,000$ to keep a company out there this year which is more than it is worth.

It has sure been hot here lately. We sweat something awful but I hope it is cooler when we travel. It gets cool every night here on the Missouri bottom. There has been no trouble with mosquitos yet.

Yesterday a fleet of [Army Air Corps] pursuit planes came here and sure gave some thrilling exhibits of fancy flying. They are small and streamlined to the $n^{\prime}$ th degree. I believe they land at a speed of 125 miles an hour. 
Big nuts "Col. Anderson," visited us this noon and said that our company was the lousiest bunch in the fort. He gave the cook hell too and they are putting out better meals than the army chefs did. I think he is big headed or likes to hear his mouth rattle. We have ice cream for supper tonight. We have a lot of ice tea now.

If I can get off Sat. noon I will come home. If not I will stay. I am going to Uncle Frank's if all I get off is Sun. I was playing ball a few minutes ago and the catcher got the pill [baseba11] on the finger and broke it. Eric sinnett is sure a real player. Well how is Grampa?- I hope he is better. No news so will close. Send no more letters here.

Norman

We11 send cards on trip.

6/ Otis Button was the twin brother of 0pal Button, a good friend of my sister Ruth's.

7/ Andrew Lundstrom, my mother's father, was the ancestor referred to as "Grandpa."

Ft. Crook, Nebraska Thursday

June 9,1933

Dear Folks:- We are going to have an orchestra here and I want you to send me the horn by insured parcel post. We won't leave till Sun. or Monday. If it arrives too late it will be forwarded. Had to hike this morning about 5 miles. Quite a bit cooler today. The new officer is quite a bit tougher than our old ones. We cannot get off Sat. or Sun. Have to load [railroad] cars. We11 I think I'11 take a bath now and mail this on the way. So Long.

Norman

Don't forget the horn and all the slides.

Railroad Post Office

Lincoln, Nebraska

June 12, 1933

5 p.m.

Dear Folks:- Left the Fort at 4 o'clock. We are in Ashland [Nebraska] now. Just passed over the river. Train not very fast but long as a freight. We are traveling in $12 \mathrm{sec}$. drawing room Pullmans. Cool riding. Denver by breakfast. Spent a bad night. 6 of tentmates drunk and raising the devil. slept about two hours. All but 3 companies left the fort today. Do not know where we will locate. Uncle Frank down last night. 33 [CCC men] in one [Puliman railroad] car. 
Denver, Colorado

Tue. a.m.

June 13,1933

Dear Folks:- Just arrived at the Union Depot. Slept fine. It is about six. Made pretty good time. Crops poor from Omaha to Lincoln, good from there to Atlanta [Nebraska], (dark then) nothing in eastern Colo. Good in irrigated district east of Denver. Helped make berths last night. Everybody has good time. No word [yet] as to future address and don't know for sure when we go. Saw the worst land I ever have seen at daylight near Ft. Morgan [Colorado].

Norman

Tennessee Pass, C0 June 13, 1933

Dear Folks:- It is about 3 p.m. now and just pulling out of Leadville [Colorado]. The smelters are working $24 \mathrm{hrs}$ a day now. Business is picking up considerably according to the [railroad] crew we have now. It has been a very poor day to take pictures as it rained and snowed all of the time. I took 7 pictures and will take another soon. The engineer on this train is pretty rough. They feed us awfully light, I suppose to keep us wel1. The mountains are covered with snow.

The timber is getting bigger all the time. I saw a fisherman with a $51 b$. trout, also a beaver dam. My hegh is heavy. It is raining hard now. Soon will cross [continental] divide.-

Sincerely,

Norman

8/ This divide is better known as Tennesse Pass on the old main line of the Denver, Rio Grande and Western Railroad.

Railroad Post Office Ogden, Utah

June 14,1933

Dear Folks:- It is about six o'clock. Just rolled into S.L. [Salt Lake] City. It was swell scenery yesterday and is starting out better now. The city is sure pretty. I am in the lounging room now. It was sure cold over the mts. The country west of the divide is prettier than that east. Cloudy again this a.m. but no rain.

Noman

Get to Sacramento in 24 hours. Writing fast so can mail at stop. Saw a cinnamon bear along the Eagle River yesterday. Just passed and saw [Mormon] temiple [in Salt Lake City]. 
Carl in, Nevada

June 14,1933

Wed. Noon

Dear Folks:- We are going through Nevada now. The first 125 miles of Odgen [Utah] was pure white sarid and a few distant snow capped mountains. The trip over the [Great Salt] Lake took about an hour. Haven't seen ten people in 200 miles. There are few roads here and the mts. are high but not rugged. I think they would be easy to climb. Many gold mines here. We are getting into a better country now, scrub evergreens, sage brush, and partly yellow and orange flowers which scent the air. Abandoned railroad parallels ours.

Norman

Fernley, Nevada

Wed. a.m.

June $1.5,1933$

Dear Folks:-

We are just pulling out of Fernley [Nevada, about 35 miles east of Reno] which is one of the regular desert towns, awfulty run down. It was sure hot today but cool in the Pullman. A storm is laying in the mountains NW of us. An awfully big engine is hooked on us now. I took only 2 pictures today. I'm afraid they are all no good. We are going to go north at Fernley now.

Nothing but sage brush and mountains to see now.

Norman

Arrive at camp tomorrow at 9 o'clock a.m.

Railroad Post office Klamath Falls, Oregon June 15, 1933

Dear Folks:- We just passed the [Oregon] state line when I woke up. We have a Mallet engine pulling us and one pushing. This valley is mostly farm land. We passed through a forest about an hour ago. We will arrive in Roseburg shortly after dinner if we have no trouble. The mountains are lightly timbered. May write a letter tonight.

Norman 
Railroad Post Office Roseburg, OR June 16,1933

Friday, a.m.

Dear Folks:- I saw more forests yesterday than I ever expected to see. We are going to go to [the Drew CCC] camp this morning by truck. It is 60 miles from the nearest R.R. town. It will be 1,300 feet high. My address will be C.C.C. Co 754

Tiller, Oregon.

I have been feeling down for a day now. Have a sore throat, headache, caused by lack of exercise. Feel better this a.m. arrived at 4 o'clock yesterday afternoon.

Norman

Camp Drew, Oregon

June 15, 1933

Dear Folks:-

We arrived in camp this morning at ten. The camp is located in the Umpqua National Forest. The Umpqua River, about the size of the Elkhorn (River in NE], runs six miles from camp at Tiller. We are located on Elk Creek, which is about twice the size of Pebble Creek west of Scribner. There are trout in this stream. Would you take part of my pay and buy a new fly rod, some good flies, a small trix oreno, and gut leader, and send it out so I can fish? We are 59 miles from Roseburg and I won't get there for weeks. They say the trout aren't big here but are above the legal limit.

We will not have to work till next Mon. morning Srgt. Teebken said this afternoon. The forest rangers will have control of us from 8 in the morning till 4 in the afternoon. Also they told us hereafter military regulations would control us. The advance company say the work is very easy. It is certainly cool here, not over 50 today in the shade and all shade. Quite a difference from the sandy desert of Nevada and Utah.

Mountains rise all around the camp. Not tall ones but heavily timbered. The biggest pines are about three feet through and awfully tal1. They say there are many bear, deer, and all kinds of game here. I should think there would be pine martin and fisher. The prettiest Mt. I saw on the whole trip was Mt. Shasta in California. It was also the tallest mountain I believe. I didn't think Royal Gorge is near as pretty as Eagle River canyon. I just have so much to write about I don't know where to begin at. Everyone seems to be writing home now. I believe it will take a long time for a letter to get here [from] Fremont. The most deserted places were first the Utah desert west of Great Salt Lake, second the Nevada desert, and third the country west of Fort Morgan, Colo. We will not get sheets to sleep between now, just horse blankets. We drink out of the creek that we swim in and it is awfully cold. They use burros for packing over the hills. They certainly are stubborn. They added some local men to our company. There are a lot of snakes here, they say mostly rattlers, blue racers, and garters. I suppose that I will get to kill a few rattlers before I leave next fall. 
After we turned north [on the train] from Fernley [Nevada] we went past a lake 30 miles long called Pyramid Lake. The water in all the lakes and rivers is perfectly clear and looks like good fishing. Then we next saw the lumber mills at Klamath Falls and a lot more places north of there. Pelicans nest there by the thousand. The divide north of there is the most dense timber I saw and there were the most tunnels. The snow was all around the car here and the streams were high. The peonies [flowers] grow wild here by the thousand. Also columbines, and flowering almond. The trees have moss hanging all over them. I saw quaking aspens here too. They are a white barked cottonwood. The government is sure not wasting their money out here like they are in the park in Fremont. - I have taken 2 rolls of film. The first I am afraid is no good at all. The second came partly unrolled when I took it out of the camera as it had stuck. I will send both home soon and I hope I have several good pictures. Both stuck at the last rolling up. The first tore a lot. The weather is just right to take pictures now and I took three of the camp today and I hope they are good.

I sure like riding in a Puliman. It is a lot smoother than a chair car. The first night and second I didn't wake up a time. The food was terribly light though. I think cooking for us in a baggage car is hard. There is no place to play baseball here except a little catch in the road. I think fishing will be my only sport and I won't get to town. The hamlet of Tiller is giving a dance in honor of us next Saturday night. They say they will import the girls from Roseburg. The wind is sure cold here now as the sun is behind the hill. The altitude is 1,400 feet here. We are a long way from the Pacific ocean. Our tents are just temporary till they can make ones with a board bottom and wal1s. Lumber is cheap here. Oranges, large ones, are \$.15 a dozen. The Govt. paid 1.5 cents a mile for our transportation.

I hope I get a letter from you soon. Has Emerson caught any fish? How are Red and Joe and Swartz? How is Grampa? We11, I gonna quit writing now because I'm tired. The address should be.

Norman Myers,

C.C.C. \#754,

Camp Drew,

Til ler, Ore.

9/ A CCC camp was located at the Nebraska Game and Parks Commission State Lakes at Fremont, Nebraska in 1933.

Tiller, Oregon

June 17,1933

Dont't send any fishing tackle. They just posted a notice on the bulletin board that no member of the CCC can be allowed to fish or hunt and they wouldn't tolerate it. So I might as well forget it now. 
Tiller, Oregon

June 19,1933

\section{Dear Folks:-}

We11 right after I wrote the last letter I went up the creek about two hundred yards. I got up above the pool on a big rock and looked into the water and there I saw a little fish about six inches long. Then after a short time I saw a bigger one right beside it. It runs a good foot 1ong. Then in a short time I saw one a good 16 inches long and I'11 bet it weighed 2 pounds. It had a red tinge on its side. Is this a rainbow trout? They put a notice on the bulletin board that nobody could fish or hunt but you can if you have a license. They say it costs $\$ 10$ but a book I have says $\$ 3$ for fishing alone.

I sure notice the different flowers there are here than at home. Beautiful yellow poppies, wild peonies, and wild flowering almond are the thickest. The only flowers (wild) found in Neb. that is out here is the Columbine. Lots of blue flowers of different kinds too.

I didn't think the mountains [out] here were high, tijll I started to climb them. They are steeper than the bluff at Cecil's 1 - and are heavily timbered. They call the forest here a fir forest. The strawberries are 1 arge and very sweet up high in the mountains. A number of the fellows have had to have the Doctor remove wood ticks. They always have the Doctor dig em out.

They ordered all of us to swim the other day. I think the water was below zero. It is perfectly clear as you can see a man down 8 feet. They have almost all quit going in now. The weather is always the same here. Clear and warm in the afternoon and [CoOl] in the evening, then foggy in the morning and cloudy till noon. The sky is a pretty blue out here.

There is a baseball diamond up the canyon about two miles. It is awfully poor though. I played up there Sat. but I was too tired to play Sun. Climbed too many Mts.

I had my first taste of the real work today. It is not going to be hard when I get used to it. We start to get our tools at 8 in the morning and check them in at 11:45. We get out tools at $1 \mathrm{p} . \mathrm{m}$. and have our tools in by 4 . This seems to be short hours. The men are under the forest ranger bosses while out of camp.

The town of Tiller gave a dance for the boys from Neb. Sat. night. Nearly all of the kids went and while some were looking out of the window the wall burst out and Russell Redding, a tent mate, got a fractured wrist from it. The pavilion was an old building I guess. Many half-breed Indians were there. The next time you send some paper, put a couple of pieces of music in the package.

There are a lot of snakes here. The kids killed a rattler with 8 rattles yesterday. Then there are blue racers, adders, garter snakes, scorpions, lizards, and mosquitos as large as airplanes. 
We just had chow now. It is better than when we first came out. I guess the cooks were all stirred up then. The people up here are sure hillbillies. One I talked to yesterday said it would be better if all of the trees were burned down and they could pasture cattle on the mountain sides. He said there was no money in timber now. They have hired about 20 of the local men to work with us.

An airplane came down in the mountain close to here last Fri. night. They have not found it yet. The kids are making a garden out in Tiller now and we will have our vegetables. How is your garden now? Has it rained?

I expect to get a letter next Friday or Saturday. Hoping you are all well, I remain,

Norman

10/ Cecil Coates, my cousin, had a farm southeast of Fremont along the Platte River bluff.

Ti1ler, Ore.

June 23, 1933

Dear Folks:-

Got your letter you addressed to Ft. Crook today. Are not the crops in Dodge County about burned up by now? I sure hope they have a rain soon. It is getting dry out here now but felt a lot like rain this afternoon. I should get another letter about tomorrow noon or perhaps Mon.11 t was certainly strange about the mixup of trains they had at Fremont. 11 When we arrived at Odgen a week ago last Wed. another trainload of C.C.C.'s were there. These were from Youngstown, Ohio, trained at a Fort in Kentucky and hauled to California via Kansas City, Denver, \& Odgen on the U.P. [Union Pacific railroad]. I believe thie major movement of them was when we traveled. Three trainloads left Ft. Crook that day.

We had to work all this week and it wasn't very hard work either. Most of the kids are good workers. The only loafer on the job is a kid from Hooper. The major told him today that if he didn't get down to work he would send him home. I worked in the woods Tuesday morning. There is an evergreen tree that grows here with a leaf like a deciduous tree. It is called the Mountain Laurel or the Madrone. It has two sets of leaves one which lets go this fall and the other next fal1. A new set of leaves comes out as soon as the one set falls off. There is alder growing along the creek which has a leaf like the Nebraska Maple. I also identified the first Hazel brush I have ever seen. It is thick here. Many of the kids have been troubled with poison oak. It is as bad as poison ivy.

Wed. and Thur. I had to split wood for the kitchen and I thought I had the job for good but today they called me out to work brush in the mountains. I have not seen a dozen birds since I came out here. I thought the mountains would be full of them but it seerns not. Nothing to eat causes it I suppose. 
I think the Oregon weather is swell to work in. It is so cool, about $60^{\circ}$. The nights are clear now and getting a bit warmer or else I am getting used to this. The airplane which is lost I don't think is found yet.

Last Sat. morning the horseman saw a big buck deer in the barn, only a gully, when he went out to feed the horse. They say that the deer are just lousy out here. One man told me he killed 42 out of season last year to keep his family in meat. There are no coon [racoon] here even though there are lots of hollow trees. I guess the environment is not suitable. The trees are so tall even if you treed one, you couldn't get it. There are some pine martin in the timber. There is a $\$ 20$ bounty on Mountain Lions and there are quite a number killed here every year. They hunt them with hounds. The natives say lions are found wherever deer are found. There are no muskrats in the streams here. I don't believe the trapping is better in Neb.

Tuesday and wed. the food was just awful. A lot of kids complained and Capt. Sutton got mad. He started feeding us 3 times as much then. Some say he was trying to make a profit on feeding us. I never said anything though as I didn't want to get in bad. Last night the kids got their first taste of fighting fire. It was just a small one though. There were 15 out all night. It was set by a fire bug and the natives say a lot will be set this year.

I am going to buy a fishing license as soon as I get my next pay. It costs \$3. It will be my only chance to fish trout and I will always remember it. Send me the casting rod (or buy a fly rod if you believe it would be better), some flies, several gut leaders and a small trix oreno. Some good line too.

Norman Myers

P.S. Are you working for the Tribune yet? $\underline{12 /}$

11/ An article in the Fremont, Nebraska Tribune stated the Dodge County group of CCC men passed through the city as a section of a regular Union Pacific train. This was incorrect.

12/ My father was working for the Fremont, Nebraska Tribune, a daily newspaper, at that time.

Tiller, Ore. June 26, 1933

Dear Folks:- I received the first letter you sent me Sat. noon. Tonight they handed me a Tribune. It looks like you are having it sent. Well, this pay check mostly goes for a fishing license and I will send 5 dollars home Aug. first. There is no place to spend money here so I will send enough $\$ 5$ home to pay for the expenses for postage, picture developing, and fishing tackle, and newspaper if it comes steady. I am getting a lot of stuff out here but I might as well have a good time. Have Emerson write to me. He will write of the things I like to hear of most. The train ride was much above my expectations except Nevada. If I ever go through that state again it is yoing to be at night. The irrigated land I saw coming out was sure fine looking compared with the other dried out crops. How are the cherries on the tree at home? 
Sat. afternoon I walked up to Drew. It is just a small country store up the road a mile. Bought a dimes worth of candy and ate it all as I was hungry for sweets. On the road up to Drew I noticed that the flat leaved pine, I think they call it the Arbor Vita, grows very well here while it dies so much in the nursery. It must need a moist, cool climate. I forgot to tell you I also got the papers Sat. and read them all.

Sat. morning I did my first real washing out here. They have the hot water handy so it wasn't much of a job and the creek is a good place to rinse them. The company also got three new Chevrolet trucks. We now have 1 International fire truck, 2 Ford 4 's, 1 Ford V-8 ambulance, the 3 Chevies, and a Dodge. In the afternoon I helped unload a big semi-trailer of lumber. One also came out Sunday and I was at the ballgame and didn't get to unload it. Didn't get to play there were so many teams. The playing pield is poor as it is about the size of a good kitten ball pasture.

Today they started building a number of tent floors and sidings. We will have good tents within a week. They are going to build a fine mess hall and cook shack. Then every tent is to have running water and one big bathroom with hot and cold water. Ail of this is just planned though. I saw by the paper that [CCC] Co. 753 is in Fremont now. I get to see a Portland paper occasionally but they are poorer than the World-Herald. - They certainly carry different news and no agricultural news; only Salmon and Lumber. I saw where Orphan Annie was kidnapped by Pinchpenny.

It rained a little Sat. night and put off the danger of fire for a while. There is a big fire on the Fourth of July out here just as sure as it rains in Nebraska. The Major said that if the conduct in the camp is good then we may get a trip to the Pacific ocean during July. They will take 20 at a time if there is no fire danger. Then later we wi 71 be taken to Crater Lake Natl. Park for a short trip. These are not at all sure though.

I worked up in the forest burning brush today and didn't get back to dinner tiil 1:30. The fire got away from us and had to call help to build fire lines. The underbrush burns like a box of matches. Went swimming tonight to clean off. They have notified us that we can't take a bath without trunks on because it is too close to the hiway. A tent mate of mine killed a rattlesnake today and brought the rattlesnake's rattles back as evidence.

The kid I told about being so lazy, from Hooper, went over the hill Saturday. Well I hope this finds all of you well.

Sincerely,

Norman

13/ The Omaha, Nebraska World-Herald is a daily newspaper, the only one still published in that city. 
June 30,1933

Dear Emerson: 14/

Well I am going to use yellow paper to write home now because the linen paper is about gone. It hardly seems that June could be gone but it is. We get our pay tomorrow. For a while they said we wouldn't get our pay till the 5 th. The town of Tiller is going to celebrate the Fourth of July the 3rd and 4th. Half of the camp will get off the $3 r d$ and the other half the 4th. There will be a lot doing and they expect 4,000 to attend. I am going if I can.

I received your letter Tuesday noon and was sure glad to get it. I am feeling better now. The last night on the train I caught a cold. It turned into a sore throat and gradually worked up to my ear. I went to the doctor several times and he said it was the mastoids maybe. However it cured up a couple days ago and I sure feel swel1. The mountain air is, 19 fresh. I sure wish I could celebrate the anniversary with the Lundstrums. 159 I probably will next year if it happens. I saw in the paper the Harold Schnoor and [Viola] Flamrne were married. Nordie [Pruyn] must have had good luck fishing lately. I think that it would be too hot to fish much now. It sure was too bad that the camp of the Swedes had to go. I sure like the climate and scenery out here in the summer. They say it rains all winter so that wouldn't be so good.

They say that there are some coon in the mountain but I have looked in every spring and stream and haven't seen a single track. Perhaps I will see them in the fall. The condition of the ground is that you cannot see many tracks. Today we worked up into the mountains about nine miles. This country is virgin forest. Never saw the sun clearly today. The country is awfully dark beneath the timber. For about 6 miles we went by truck and the rest of the way walked in a deer path.

We cleared it out so a pack horse could travel. This is real fun ground but I am afraid I would get lost. There are several abandoned cabins and no trails. A lake is near there and we will get there the next time we work. There had ought to be good fishing there. We don't have a radio in camp.

We are not going to have an orchestra but I will get a lot of enjoyment out of the horn. The other kid quit bugling and I got the job. The taps are blown at 9:30 and the morning call at 6:00. I am running out of news now so there won't be any long letters. I am beginning to explore the country now. I forgot to say I saw the tracks of a big mink or otter the other day.

The first part of the week we worked in an awful steep canyon burning brush. My legs sure got tired. Then we moved up the canyon about a half a mile to a level valley to clear timber for a road to Summit, a lookout station. Passed it going to work today and can see at least 50 miles from there. It is 2,000 feet higher than the camp and only 4 miles away. There are no fires now. A little too damp. Soon will move into new tents with floors in. Helped unload three loads of lumber at off times this week. Thursday they started to dynamite stumps. Tried to get on but didn't. I guess I look too sloppy. You have to do whatever they give you anyway. Thur. afternoon we 271 got a lesson in chopping by a forest ranger. An Indian joined our company Wed. Many Indians live in the hills here, mostly Umpqua and Flathead. 
Glad you went to air races and enjoyed them. I see grain jह/rising and the depression is shot. Got the music, [pictures,] Criterion, - letter from Russel Heese, and Mother. Will answer mothers Tetter Monday. Received map and Geographic at Ft. Crook. Enjoyed them.

Norman

14/ Emerson, my brother, was 20 months older than I.

15/ Andrew and Inga Lisa Lundstrom, my grandparents, celebrated their 59th wedding anniversary on June 23, 1933.

16/ The Criterion is a weekly newspaper that still is published in Dodge, Nebraska.

Ju7y 3, 1933

Dear Folks:-

I have two letters to answer now and will answer both in this letter. Received yours Mother just before I wrote the letter to Emerson. It takes about a week for a letter to get here. I received the first one postmarked June 27, on June 31 at night and the one postmarked June 28 today July 3 . The papers come faster than the letters. Received music, card, and papers and card Friday too. The music was what I wanted. Just anything to pass away the time. I write every Mon. and Fri. night, so if you don't get a letter every 3 or 4 days it is the mail service.

Wi11 answer yours first Mother. The poppies do not grow at this place. They were thick till I got to Tiller and above there there are none in this canyon. However, there are lots of pretty flowers here and I will save some of the seed if I can. I hope the C.C.C." s in Fremont can improve the fishing there. I am sure glad we weren't sent there as our trip is easily worth $\$ 100$. I saw by the paper that Helen is home from Chicago and that she took a boat ride. It is sure strange how Grandpa improves after he is so low. I bet Grandma is glad her garden is watered. Is the corn ready to eat yet in your garden? The heat was always hard on the hounds even out on the farm. I think I will be well trained to hunt coon when I get back. I think that eventually Swartz will have to be sent to the farm. I wrote Lambert- a letter about a week ago. Did they get it?

I sure wish you had some of these cherries they have out here. They have Bing, Royal Ann, and one other kind. The Bings are high priced but good. We had Bing cherrie pie the other day and it sure is good. The Royal Ann's are redder than I thought they would be. Several of the locals bring them into camp and eat them as if they cost nothing.

I might be able to find out from a forest ranger about Hilma's land. 19/ My work is ever changing. Mostly chopping brush, clearing trails, and burning brush. I am sure glad that we don't have to worry about the crops and prices. The pictures of the camp were taken at noon on a clear day and in good light. I was surely pleased with the picture of the Mallet engine. It took that one and another pushing to pull us over the Cascades. We saw a 90 car freight which had one pulling it, two in the middle and one pushing. 
Now answering Ruth's $20 /$ letter. I have written many letters and received few. I think it is that the letters are a week enroute. I am going to press a number of flowers. They are so different than Nebraska's. I will sure be glad when I get the fishing tackle as fishing is pretty good now. It will cost a lot of money but is cheaper and better than smoking or drinking up your money. Any kind of a fly rod is all right. I like our camp here better than Ft. crook. Such gorgeous scenery. We moved into floored tents today. The mess hall will be built in several days. Going out on the train the kids said I was throwing away the films taking pictures from the train. They were pretty good though. You have your two years of college now when you finish this term, don't you? I hope Emerson don't lose his job now. Funny what a drink does to a man. You sure can see the folly of it in camp. 7 have deserted camp so far. The first 6 left last Saturday after they received their pay. Emerson ought to start looking for coon tracks along the creek soon as I am raring to go. We11 I think this covers your letter so I will write the news from here now.

Our new tent has a wooden frame and no stakes. The creek is 2 feet from the back door and will not have to go far to take a bath. The front is about 20 feet from the highway, facing it.

We got our pay Sat. morning and my share was \$5. None of the members of our company received a raise this month but will get one next. I don"t have any chance for that though. I just froze in bed Friday night it was so cold. I like the climate better than in Nebraska if I had enough covers. The air in the daytime is so cool and crisp. I think the timber has a lot to do with the climate. Sat. p.m. I went down the creek panning gold. Didn't get any but saw the first coon track. Also saw mink tracks. The flowers down the creek are much thicker than in the canyon above. During the middie of the week 6 kids went to Vancouver, Wash. and got new trucks. They went up by rail and drove back. They sure liked the trip.

The big shot of this Army Corp area inspected camp Sat. He talked a lot to the kids and gave the Officers hell for the way they kept camp. Regular army style. They have to build the mess hall immediately. The head Ranger Meserve kicked about the grub and that will probably improve it some. The Army Officers and Rangers are all good men though. The kids just hate the Major but I [sure] like him. When I was sick after the trip he was good to me.

Sat. night $3 / 4$ of camp got drunk. They just waste their money and health. They have started a post exchange and I have bought 3 bars of candy from it. Also hob nails and had them put on my shoes. They charge $10 \&$ for the nails and $10 \varnothing$ to put them on. I have spent a lot of money lately when I intended to save it. I have not broke my 5 yet and have $\$ 1.39$ in change. The fishing 1 icense will take $\$ 3$ of it.

Sunday morning I went fishing up Elk creek with Red. $21 /$ Red caught 8 trout but they were small speckled ones. I sure had a lot of fun watching him. He used a red hackle dry fly. I sure found a slug of coon tracks in the mud up the canyon a mile. Red told me it was nothing but porcupine tracks but I'm sure it is coon. They are as thick as on Elm Creek. Also found salt lick and saw millions of deer tracks. Red cleaned and fried fish and I sure stuffed myself. They are real good. Red has to hide every time he sees anyone as he has no 1icense. Sun. p.m. went to bal1 game. Camp lost to Canyonvil1e 28-10. 
I sure feel good now. I sure like to get the letters and paper. With lots of love,

Norman Myers.

17) Helen is my cousin, Helen Luther, the daughter of Hannah Luther, my mother's sister.

18/ Lambert was Lambert Dloughy, a neighbor living just west of us when we farmed.

19/ Hilma Bjorquist was mother's cousin. She apparently owned some land in Oregon.

20/ Ruth is my sister. She married Harold W. Caldwell.

21/ Red was a Cook at Camp Drew. He was a member of the Regular U.S. Army.

July 7,1933

Dear Ruth:-

Received the fishing tackle on the 4 of July. It was just what I wanted. I didn't go to Tiller on the 4th as I figured I would save the money and buy the fishing license. I sure had a lot of fun anyway all alone. I left right after dinner on a hike up the mountain south of us to pick flowers. Within a quarter of a mile of camp I found a patch of poppies. They were in a flat meadow in the Drew [Creek] Canyon. During the climb I collected 27 different varieties of flowers and have them pressing now. I hope I can bring some home as they are as pretty as I have ever seen. I will get all the seed I can and bring home. After walking about 5 miles I came up to the very peak of a mountain. The forest was so dense it was twilight on the ground so could't see any of the country. I saw a gray timber [silver gray] squirrel, the first one I have ever seen. It's ears are very prominent, and al so a mountain Jay for the first time. There were several quartz formations on the upper region which were sure sparklers. It is very cool, I should say about $45^{\circ}$, on top of a mountain in mid-day. I arrived back at camp at 5 bell[s] awful tired but also happy. There were deer paths all over the mt. but didn't see a one. About a half a mile from camp I flushed a mother grouse and about a dozen $1 / 3$ grown ones. They were sure cute as they could hardly fly. Just as I am writing this a quail flew into the tent and lite on a cross piece. Then it flew up the mountain a ways.

Almost everybody in camp was at Tiller. They charged too much for the stuff though. They charged $.50 \$$ to see the boxing, $\$ .50$ for the dance, $\$ .50$ for the rodeo, and $\$ .10$ for pop and ice cream. I figured I would spend this money for fishing tackle and license. The camp's baseball team won its ball game both days. There is not much in the way of ball teams up here.

There sure has been a lot of trouble brewing here since the Fourth of July. Capt. Sutton and the Doctor got drunk down at Tiller and were disorderly. They were ordered out of the dance floor and one store. Then they came back to camp early in the morning and couldn't walk, just rolled around on the ground. It happened that the District Supt. of the Forest Rangers, Mr. Rodgers, 
saw them. He called the head of the Army in this district and an inspector came several days ago. He transferred Sutton and the Doctor somewhere. That is the same as firing a man. There has been a lot of kicking on the food again. Many of the kids said, "more grub or no work." Some of the kids in my gang tried to make me quit work but I kept right on. I am satisfied with the grub as I have had lots worse but it is not as good as we had at the Fort. They have 6 of the men up on the carpet for it now and I may be able to tell you how it turns out by the end of the letter. The Army inspector asked the kids a lot about the grub and how they liked the camp. This morning all but one of the forest rangers turned the lunch the kitchen put out for those to eat at noon on the job, back to the cooks as unfit to eat. Then they hopped on the Army officers for putting out such a lunch. The Army and Forest Depts. are like cats and dogs when together. Tonight the new Doctor asked the men how the grub was and some said they didn't get enough for breakfast. He called them son of a bitches and in 10 minutes the Major was out and took down the names of the kids that heard him [the Doctor] say it. Maybe we'll have another new Doctor. I never kick and always work so I keep out of trouble.

The creek murmers just back of the tent all of the time and it sure is fine to sleep by. I went fishing Wed. evening as the fever came to great to overcome even though I didn't have a license. I used the little gray fly with a red tail. Maybe it was luck but I caught 10 speckled beauties. I threw them all back as I didn't have time to fry them. I found out you can't get them to strike in a pool, it has to be a rapids. Four were big ones and 6 were small. The rod is sure a dandy and I can use it when I get back to Fremont again. Would you send about 6 more flies out sometime soon, so I have some if these should break? A kid is getting a license for me at Canyonville tomorrow. I still have a little over $\$ 3.00$ left while most of the men are broke already. They spent it on wine and women. One kid is busted that got $\$ 8.00$ for boxing twice at Tiller. He got K.0. [knocked out] both times.

I am dynamiting on the new road north of camp now. All but two of the powder gang quit and I started working Wed. morning. All I do is load which is easy work and the boss is always along. I am going to learn a lot about road constructing which will be valuable in later years. The rock work is to be very interesting I believe. They load the big firs very heavy; about 350 sticks or $3 \frac{1}{2}$ boxes under one stump. It makes quite a roar. I like the loading as it is not as heavy work as the drilling 22 They drive stakes or rods to make the holes. I have not had a headache yet.

The camp is to subscribe to $\$ 34$ worth of newspapers. They chose the Omaha WorldHerald, the Omaha Bee, The [Fremont Tribune, and the Columbus Telegram. I probabiy won't need it [the Tribune] another month if this is true. I will tell you later though. If I happen to not write on time some day it will be because of the fire trouble. One will break out soon if it don't rain.

They are sending many of the men to outlying camps to work. Twenty four are up on the [South] Umpqua R. falls north of Tiller. They say hundreds of 30 or 40 lb. salmon jump and swim over the falls. The water is so clear you can see them. Wed. morning they moved 24 to Devil's Knob. This is the highest mountain around and is snow covered yet. Then another 24 will go to Beaver Lake. I will not move for awhile yet. The [six] kids [who complained about the food] just got back from the orderly tent and only got K.P. [kitchen police work] for Sat. and Sun. 
I received Ruth's last letter written Mon. on Thurs. morn. Only three days coming out. The weather is still cool here and always will be. Yoy certainly had a house full of relatives Sunday. How is Uncle Will making it? $\frac{23}{\text { Russell }}$ [Heese] told me in his letter that Julius was sick. I hope you all had as good a time on the fourth as I did. They are nots sending out paper any more so I would like to see the funnies. Does Morgan have a good job now?

Swartz must be getting to be a flirt. Are they doing much work in the nursery now? I sure am having a good time out here. The time sure flies. I'll bet that the six months will be up before I know it. Well this is all the news now so I will close.

With lots of Love

[Norman]

22) Many times the handling of dynamite made with nitroglycerin results in a person having severe headaches.

23/ My Uncie William H. Myers was a traveling singer with an evangelistic group.

24/ Russell and Julius Heese were our neighbors when we lived on the farm.

25/ Morgan Myers was my cousin living in Omaha, Nebraska. Although he was getting about $\$ 10.00$ a week for working at that time, the firm instituted a $10 \%$ across the board salary reduction and he resigned as a result.

JuTy 10, 1933

Dear Folks:-

I am going to start my letter this morning before I go to work so I will have a. little more time off tonight. We are sure getting good grub now and I should think the kickers would feel cheap. We had fresh milk for breakfast Sat. morning, the first time since we arrived in Oregon. Worked a little extra around camp in the morning and did my washing. I had a chance to get the soft job of bugling and other odd jobs around camp but I refused it. I am going to work out on detail and bugle too. I have to work a lot harder but I will learn a lot about the construction of roads. We also got our new captain Saturday. He looks tougher than the one that was canned. In the afternoon I went up the creek and picked 5 more kinds of flowers. Many of the tame flowers in Nebr. are wild out here. I didn't go fishing cause I didn't get the license yet. A local man is supposed to bring one out to me this morning. One of the bosses brought us out a bushel of Royal Anne cherries for us Sat. morning. They are sure good. I went out in the woods and ate all the wild raspberries I

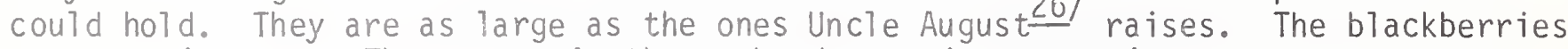
are not ripe yet. The prunes in the orchards are just starting to turn now. 
Sunday morning I read a few stories in Colliers and Sat. Fve Post. They give us the unsold copies from the newstands. They also collect the old magazines from the ones turned into the fire stations by citizens of Eugene, Portland, and Roseburg and bring them out here. They are certainly appreciated. I am

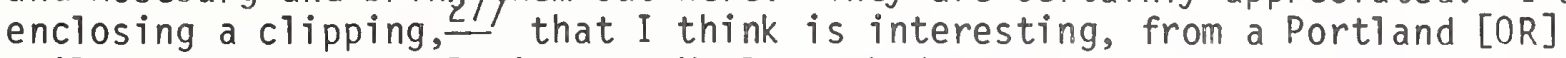
daily. We had a swell dinner. Veal, mashed potatoes, gravy, bread, string beans, and ice cream. They have to drive about 50 miles each way to get ice cream. The kitchen has a truck and gets a new bunch of bread and meat often now. Red says that if he could do the buying the company would never go in the hole. He says local merchants will sell cheaper to the camp than they get it on big contracts.

Sunday afternoon I went to Glendale by truck to the ballgame. Glendale is a 1 umbering town about 45 miles south of Roseburg and about 50 miles from here. The ball game was rotten, Drew lost 15-3, but the scenery was swe11. Saw 2 deer and many buzzards. I thought the birds I saw here were hawks but they are buzzards. When we arrived at Giendale it seemed cold and we froze to death coming home. They gave us all the ice cream we could eat for supper.

The camp detail have the foundation for the bathhouse and mess hall fixed up now. A 3 h.p. Metz Weise engine is to pump the water up the hill to the storage tank. It will sure be swell here then.

If I were you and could get away I would sure go to the fair at chicago. I bet the trip would be worth the $\$ 10.85$ it costs from Fremont. I would like to get several good tornado pictures if I could. We have awful arguments about them. They expect fires to break out soon as it is pretty dry. It is strange that all the fire bugs here are Bohemians according to the Rangers.

I received your letter today, two [Fremont] Tribunes, your clipping and music, and a letter from Leroy Black. It was worth $\$ 10$ to me. He is sure a clown. I am awfully rushed now as I am going fishing tonight. I got my license this morning. I am sure glad to get the letters. The time is sure flying now. 4 weeks ago today I left Ft. Crook. We are sure having a good time.

I worked blasting rock for the new road to Summit today. They sure get rid of the dynamite here. We just blow out the ledges, no solid rock work now. Well this is all of the news so I will close.

Hope I catch a lot of trout tonight.

Lovingly,

Norman Myers

26/ My Uncle August Lundstrom was mother's brother. He was an engineer on the Chicago and Northwestern Railroad at Fremont, Nebraska.

27/ The clipping was about the Flagship Augusta which visited Portland, Oregon over July 4, 1933.

28/ Leroy Black was a neighbor who lived just east from our old farm. 
Dear Folks:-

I see by the paper I got Tuesday that all of Nebraska got a big rain. I hope they have a lot more. How is the garden now? I am just going to address the letters to all of you now but take turns writing because I like to hear from al1 of you.

A local boy who works on the same gang I do was telling me all about trapping, last Tuesday. He traps on the high plains and mountains. His name is wilbur and got me the license last weekend. Last winter he trapped in the Rogue River district and caught 7 marten, many mink, 2 fisher, 1 bear, 1 beaver, 2 otter, 17 coon, many skunk, 3 wildcats, and no muskrats. He said he hardly broke even. He also caught several badger one which was a silver. There are no fox around here. He helped me blast rock. The rock ledges are easy to bust but the bedrock is awful. They use a coyote bar and coyote spoon to dig the holes in the ledges. For the holes under stump they drive a blow prick in. It is a crow bar with eight sides and a sharp point. About a foot from the top it is flattened so the wrench, a small bar with a $U$ in the end, can turn it when it is driven in. In bedrock we use a drill which is a round bar flattened at the end and sharp. Every lick with a sledge the man on the bar turns it a little and it chips off a little rock. It take an hour to drill a small hole. I haven't had much of a headache yet.

I see by the paper that Mrs. Norton Pruyn died at Schyyler. Is she any relation to Norton at the station? I see that corn is still going up, boy we sure made money keeping ours. If you want to use some of the money, use it. I will owe some board bill before the winter is over.

Wednesday we started to dynamite stumps and blew up 92. This is a good days work. They were all small though. Wednesday morning the captain bawled Red out for not having enough eggs for breakfast. I believe Capt. Sutton was a skunk and the new Capt. is much better. The forest ranger told the high officials that 10 hrs. of work was lost one week by the lack of food. Red also fired one cook that was worthless. The company has a good range, ice box, and many other essentials now.

I went fishing up Elk Creek last Monday evening. Got nearly up to the Drew store by dark and caught nine speckled trout. I gave them to the gang from Dodge and Snyder and they had a fish fry. These trout are sure good to eat. Three of these were about 6 inches 1 ong and the rest 4 or 3 . A 3 inch trout will sure give a good scrap though. I am going to hike to Beaver Lake a week from this Sat. and try to catch some big ones. Sat. or Sunday I am going a long ways up Drew Creek and catch some fair sized ones. The red fly is no good now as I haven't had a single strike on it. The gray ones are good and I will use the trix-oreno when I get to the bigger lakes and ponds. I also went fishing Wed. evening with several of the kids and caught 5 more. Red cooked them for us and they were sure good.

I have been eating all the raspberries I could hold lately and the big crop of blackberries will come soon. I sure wish they were close to home so we could can them. They got a radio for the camp last Mon. but it won't work so I suppose we won't have any music for a while. It was an expensive set too. Wed. eve they passed out paper and envelopes. 12 sheets of paper and 4 envelopes to a man. I think you had better have the [Tribune] paper sent to me for the next month as I have not heard whether they ordered it or not. 
We are eating lunches out on the gang now. They sent out corned beef, bread, oranges, cheese and coffee. The blasting is not hard now as the ground is nearly level and the stumps smal1. We have 2 more miles of small stumps and then about a mile of big ones. Wednesday we blew 92 stumps, Thursday 58, and Friday we just blasted in the morning. Shot out about 48. I am sure going to get a lot of experience out of it. We are to get most of our rock work later.

It has just been 4 weeks ago today that we arrived in camp. I have done my weeks washing already tonight. Then ate supper, played baseball, and got a sack of tobbaco and a pack of cigarettes free. I sold them for $10 \phi$ and bought candy with it. I can't get on the baseball team out here and they don't practice 9 so there is not much interest. I hope the C.C.C. team at the lakes is good. - They have a place to practice while all we have is a canyon. The kids are boxing a lot now and quite a few K.0.'s too.

The music I have is enough. I like to play out of the book best as it has some swell songs. Today there were 4 men cut by axes and one with a saw. This is the first run of accidents we have had out here. Tomorrow I am going to take the last roll of pictures. Will you send out several more rolls of $120 \mathrm{film}$ ? I forgot to say that I also received "I Like Mountain Music," and "In the Valley of the Moon."

In reply to Ruth's letter I received last Wed. the same day I got the package. The mountain streams are clear and in pools the water looks green. The rgcks are al1 around the water and a few gravel bars. I think I saw the ["U"] 30 . butI saw so many letters on the mountains ${ }^{2}$ have forgotten. I am sure glad the drought is broken. I am glad Blue Boy has a friend now. Well Swartz has a lot of fights now. I have seen many, stars out here as the canyon walls go nearly straight up. How işkenneth we now? He sure runs through with money. When did Lyle Johnson get sick? The bing cherries are natural growth.

Got Emerson's Tetter today. Wasn't it awful he got canned? What was the boss mad at him for? Does he know? I'll say I am sure glad I have a steady job. It took two days for the letter to get out here. I am sure feeling goog now. I think it was a good move to sell the corn. $\$ 1,200$ is a lot of money.

I sure hope Emerson has a good time on the trip.

With Lots of Love,

Norman Myers

29/ Norton Pruyn was a friend of mine in Fremont.

30/ My sister Ruth had asked me if I saw the "U" on the mountain when we passed through Salt Lake City. Our Aunt Louie M. Nichols Iived directly below this letter "U" in that city.

31) Blue Boy was a bird we kept in a cage in the dining room at our home.

32/ Kenneth wiekhorst was a friend of the family.

33/ Lyle Johnson was a friend of the family.

34/ Father did not sell the corn in the crib and driveway when we left the farm. At our sale the corn averaged less than 12 cents a bushel. The price was much higher during July of 1933. 
Dear Folks -

I am going to write part of this letter this afternoon (Sun.) and finish it tomorrow night. The days are pretty hot in the afternoon now and warmer at night but, I still sleep with four blankets on. I suppose that Emerson, Grant, and Ward 5 are up in Minnesota now, fishing. I hope they have good luck. It was sure awful about Emerson losing his job. Maybe this will be a good break and he wi 71 get a better one later. If I were him I would try in Omaha. Did you get the corn shelled yet? How did Gerthes' oats go? I bet the farm will look different by the time I get back next fall. It hardly seems possible that 2 months of my stay will be gone tomorrow. Also it is only 4 months till I get the splendid trip back. There is not much going on around camp now and everybody is resting. The ball team went to Glendale aga in today with several truck loads of the followers. They are to play another CCC camp.

Saturday morning I went up Drew Creek before breakfast a couple of miles and fished down. On the way up I picked three kinds of flower seeds but they aren't ripe so I will go in a couple of weeks and get some more. I caught 16 speckled trout. This little creek seems to be very full of fish. I caught 2 fish with the red fiy the first time I ever had a strike on it. I took two pictures of the fish, two of Drew Canyon, and four around camp. I sent the pictures home yesterday and you can keep them till I get home. Tell me how they turn out. Will you send me out two more rolls of film (120) and a spool of thread. No rush, just put them in another package. This morning I went up Drew Creek about a quarter of a mile and caught 6 trout. Tonight several of us are going to have a fish fry about 9 o'clock.

Saturday morning they told us to make our beds a different way. They sure can change their minds. I have a few spots of poison oak on my arm now. I hope it doesn't spread much but I don't think it is as bad as poison ivy. They are going to have a horseshoe pitching tournament soon. The winners in this camp will get in the regional tournament at Roseburg. I received the clippings and music Sat. I have played about an hour today. I sure like to play alone even if we have no orchestra. Saturday night I had to unload one of the last loads of Tumber. In another month the camp will be entirely fixed up. We sure had a spread for dinner today. Ice cream, chicken, mashed potatoes, gravy, bread and peas. I'17 bet your garden is swell now after the rain. One kid from the [South] Umpqua Falls [CCC] camp developed a case of leakage of the heart and is in the hospital at Roseburg.

Well it is Monday night and have taken a bath, eaten supper, and read the paper. I received the letter, book on blasting, and trout flies. I needed the flies as I have worn the best one out already. I have caught 46 trout aTready. That is pretty good. I am going to read the handbook every morning I can. I always have from 7 till 8 to lay around. The letter was good as they a 71 seem. The company BB [basebal1] team beat the Melrose camp 9-10 yesterday. They said it was a good game. 
I got some new work this morning in logging. They use a Caterpillar 40 with two winches on the backend. The upper one has small cable ( $\frac{1}{2}$ inch) and is called the pullback; while the lower is called the main drag and has 1 inch cable. The pullback is taken back about two hundred feet from the tractor, put through a block, and returned to be tied to the main drag. The pullback pulls the heavy cable back and with pieces we hook it onto big logs. It pulls monstrous logs and clears the ground fast. This noon we ate in the camp again. This afternoon we shot out 1 stymp and pulled some with the tractor. We are going to use an electric machine now. Well I am about out of news now so will close.

With Lots of Love Norman Myers

35/ Grant and Ward Lundstrom were Emerson and my cousins.

36/ Previous to getting the electric device to detonate dynamite caps, we used matches or punk to light powder filled fuses. With the electric plunger we were able to use electric blasting caps. The latter is a much safer procedure.

Tiller, Oregon JuTy 21,1933

\section{Dear Folks -}

I am going to write some to you tonight, Wednesday and then put the last part of the letter in Friday night. I had to sign the payroll last night. We have to sign it about the 20th of each month. Then they took the size of our shoes. At the 3 month period they are going to give us new shoes. We are building a new fence now. The road cuts across a homestead and we have to build a fence along it. We have had to log, pull stumps with a cat, and blast a little.

I got a card from Emerson today. It sure was a dandy one. It was mailed from Sauk Centre [Minnesota]. I looked it up on the map and also found Turtle Lake where they are going to fish. What relatives live in Brainerd [MN] that he is going to visit? They are sure going far north to fish. I went fishing downstream (Elk Creek) last night and caught seven trout. One was sure a big one. It put up a big fight and was surely exciting. I wish I had a camera along as it was daylight when I got back to camp and I could of had a picture of it. I like the new flies and caught the big one on a coachman. The green one broke soon after I got it and I decided is was because I didn't wet it before I used it. The gut broke right behind the hook. I am going to fish again tomorrow night.

The head ranger of this district just spoke and told us about fighting fires. He had hardly finished till they had a fire call and there were several fires on Bird Creek. He said about six out of seven fires are set. He seemed Tike a fine man. One thing he said was that a good forest fire will travel at 1215 miles an hour. The underbrush fires are not bad but crown fires are awful. Well, I will finish this letter later as it is bed time. 
Thursday evening. I suppose that this is about like a diary but I forget so much if I don't write itygften it is hard to write. I received your letter this noon. Bill Pateidly is crazy to find out how the ball games come out. We always find out on Friday's mail. So you think that the second teams in Fremont are as good as the Elkhorn [Valley leagues]. I am on the same crew as Pork and I sure like him. He is very easy to get along with.

We finished our fence today and started drilling rock to blast it. We use a hammer and drill. I will get experience in the tough blasting tomorrow. The kids are not back from the fire yet and they left about 6:30 last night. The valley above 38 rew is sure filled with smoke. We clipped the piece of Harvey Klintworth's 38 and posted it on the bulletin hoard. We are using an electric plunger to fire the [dynamite] blasts now and using No. 6 electric caps. We use $60 \%$ [dynamite] for the rock work and $40 \%$ and $20 \%$ for stumps. The [dynamite] makes they use are Giant (Atlas), Hercules and West Coast. It is all good dynamite the same as DuPont. Weil I think this is all for tonight. I am going fishing after supper.

Friday evening. I am eating some of the candy you sent me now. Got a letter from Emerson and you today. The candy is sure good. Some of our outfit are going to Crater Lake tomorrow. I hope I am one of the lucky ones. Emerson's letter was mailed from ottertail, Minnesota, and it sounds like he was having a good time. Well the week's work is almost over and there is only one more week in Ju7y. Time sure flies. We blasted rock all day today. They use $60 \%$ to blow it up. The drilling is exceedingly slow. They load the holes which are 5 feet deep very heavy.

The mess hall is completed now and all the plumbing. The water is just outside the tent. The water systegro, is real good. My poison oak has about vanished now. So Kenneth married. I wish I could have taken something dizzy to the [wedding] shower. It was too bad about the corn disappearing but I suppose nothing can be done about it. I know Scanlon real well but he is in the Fawn [CCC side] Camp now. I bugle with my own horn and have to learn several more calls now for church, fire, and first call. Thanks a lot for the candy. I will soon have it all down.

Lovingly,

Norman

Have Emerson write a big letter when he gets back.

37/ William Pateidl was from Snyder, Nebraska and had the nickname of "Pork."

38/ Harvey K1intworth was from Scribner, Nebraska. 
Tiller, Oregon

July 23, 1933

Dear Folks -

It is Sunday afternoon now and I have nothing to do so I will write when I am not rushed. I suppose that Emerson will be home by the time this gets to Fremont. I have been fishing three times lately. I caught 10 fish Thursday evening after supper in Elk Creek that were pretty good sized. I went Saturday afternoon up Drew Creek and caught six small ones. The creek is getting fished out some now but there are a lot of big ones left anyway. This morning when Red went after ice cream I went down on the [South] Umpqua [River] below Tiller to fish. He picked me up when he came back. I caught five small fish and one good sized trout. One of the small fish was yellow one, not a trout. I had a lot of big ones strike but not hook. The Umpqua ia a lot bigger than it looks. It is pretty deep too. Dave Taylor, a local, Red and I were supposed to go to Beaver Lake this afternoon but we couldn't because of the fire danger. I don't remember whether I told you to send three flies for my broken one, one green one, 1 coachman, and one any other one except red.

Yesterday morning Ralph Young, our boss, had a truck take our crew No. 4 up to Devil's Knob lookout station. It is 10 miles from camp and 4,918 feet high. It is 6 miles east of Summit Ranger Station and this is through big timber ready to log. Much of the territory that is around the lookout is burned. There are 10 lookouts in this district and 7 which cover part of this forest. I saw one deer going up and several chipmunks and quail. The man in charge showed us the way they locate fires. They have a map which is exactly correct with an axle in the center. Devil's knob is the center. The map is round and there are two sights on opposite sides of the circle with a piece of tape between. The scale of the map is $1 \mathrm{mile}=\frac{1}{4}$ of an inch. When he sees a fire he signals it and then picks the range it is $i n$. Then he takes the reading of the minutes and seconds around the circle. There are $360^{\circ}$ to the circle. He calls another L.0. [lookout] and gets his degree reading and where they cross is the fire. The lookout then picks out the road or trail there and the no. of men needed to fight [the fire]. I could see Mt. Shasta, Mt. Pitt [now Mt. McLaughlin], and the rim of Crater Lake. I could see hundreds of snow capped peaks. The prettiest peak is Shasta. Some L.O. stations 40 miles away flashed signals with mirrors. Each L.0. is connected with a telephone line.

There was a landslide on the road below Tiller Friday night and it isn't 9 gen yet. The mail was late yesterday because of it. I got a card from Cecil 190 at Spokane, and a letter from Lambert. Who is L.M.R. [Luther M. Roessler] $\underline{40 /}$ and address dad wrote of?

Yesterday morning 60 men out of camp went to Crater Lake. They said it sure was a good trip. They left at 7 in the morning and came back at 6 in the evening. All but 20 miles is paving and is good scenery. They said the trip is worth two weeks pay. They use the FS trucks and is free. I may go next weekend. 
I just finished the candy this afternoon. I had to eat it for it drew nats pretty bad. I hope the films are here by the time I go to the lake so I can take the pictures. If you can pick up a good $\$ 1$ or $\$ 1.50$ watch would you send me one. I see you sold the corn at the right time.

We11, this is all the news so I will close.

Sincerely,

Norman Myers

39/ Cecil Coates was my cousin.

40/ Luther M. Roessler was the Dodge County Engineer.

JuTy 27,1933

Tiller, Oregon

Dear Folks -

We11, I have been moved from the main camp to the Fawn Camp 19 miles east of Camp Drew. Our whole powder crew had moved up here to the higher altitude. Bill Patiedl sleeps next to me in this tent and the whole powder gang in the same tent. We are about 4,000 feet high. This camp is small having 38 men and two of them cook. They moved us up here to blast 4 or 5 miles of stump and rock to Butler Butte. Butler Butte is a L.n. and there is no road to it so we have to construct it. There is giant timber up here and most of it is burned over. The forest fires have sure wrecked this part of the woods. It is decidedly cooler up here and much windier. I believe the mail will be much slower and you will probably receive this letter late. We have running water here and that is the only convenience. Coming up this morning I saw a blue grouse and two big bucks. They were four times as big as any other one I have seen. We saw a forest fire in the hills coming up. It was only small but a crew was fighting it.

Last night when we were coming home from work on the road to the Summit a man wearing only trunks of a B.V.D suit stepped out from behind a tree and ordered the driver to stop. He was awful mad and asked the men who stole his beer Saturday night to come with him to his house. No one moved a muscle and our boss Ralph Young told us to stay in the truck. Then the hillbilly pulled out a 38 Colt, leveled it on us and repeated his demand. I happen to know who hooked his beer and none of the guilty ones were on the truck. Ray Solon, a ranger, happened to be coming from the Summit [RS] in the truck and stood to my left. His right hand silently slid to his side and he asked Mr. Young if he couldn't take the responsibility of the crew. He got it and quickly pulled his pistol on the lunatic. "Drop that gun," he commanded and the man turned six shades whiter, threw down the gun, belt of shells and cooled off. Bill P. [Pateid 1] was laying in the bottom of the truck. They took the gun away from him [the 10cal man] and he got a severe lecture from the boss and $\mathrm{Mr}$. Solon. We were scared to death and I hoped that the good Lord doesn't make me face it any more. We sure had a good story to tell the kids anyway. This man said that he wouldn't sign any affidavits accusing any of the men in the truck. 
I suppose my fishing is over for a while but I have surely had 3 dollars worth of it already. Last Monday evening I caught 14 trout in Elk Creek below camp. They were sure beauties. Tuesday evening I got three up Drew Creek and I scared up a flock of blue grouse. I would sure like to hunt them sometime. Next month or in September I am going to take a longer fishing trip.

Last Monday a.m., I finished blasting the rocks and got to the stumps again. Have blasted stumps Tuesday and Wednesday all day. I am sure getting a lot of experience. A kid that blasted with me got a $\$ 45$ a month job in David City [Nebraska] and left. He had his fare paid home and also meals.

I suppose this letter will take a while to get to you but I can at least send it on time. Would you send me four tubes of Listerene toothpaste and three rolls of film sometime in the next 2 weeks? I will need them eventually. I will send you home some money next Tuesday. I can't get a thing out here except by mail.

You were sure lucky to sell the corn when you did. How much was in the driveway? Did you sell all of it? Who helped shell it? Haul it? They nearly completely quit baseball here now.

Cecil wrote and was going to visit me tomorrow but I had to move. I sure am sorry but I have to go where they send me. He wrote from Spokane. Got your letter yesterday.

Lovingly,

Norman

Getting awful cold tonight.

Tiliter, Oregon

JuTy 28, 1933

Dear Aunt Hannah:

I will write you tonight while I have time. I received yours several days ago and it was enjoyed. I see by the paper that Emerson is home from Minnesota. I hope they caught a lot of fish. It was a great trip I'll bet. The Swedes certainly lost the island in short order but I suppose that they can find another. I hope John makes good in the filling station but it will be hard in his location. Did he lose or quit his job in the laundry.

I have been moved since I wrote the other letter. We are now located in Fawn Camp, 19 miles east of Camp Drew. We are on the divide between the Umpqua and Crater National Forests. There is a lookout just $4 \frac{3}{2}$ miles northeast of us at Butler Butte. It's altitude is over 5,000 feed while we are about 4,000 feet 
high. If we can get into the open we can see several snow caps. From the lookout one can take a fine picture of Mt. Shasta in California. Also one can see [the] Crater Lake Rim. We have only three large tents in our camp and two small flies. The bosses stay in the small tents. Only 36 men live here and I like it much better than the main camp, however the mail is awfully slow. I haven't gotten it for 3 days. I can't get to town so will have to have everything sent out from home.

We have to build a road about 5 miles around the mountains to connect with another the other side of Butler Butte. Six timber fallers lead the way and fall all the trees and several more men chop out the small timber. Then our crew comes and dynamites out all of the stumps and rock. The working on rock is very slow and we are glad very little of it is done. Then a Caterpillar with a bulldozer ( $a$ blade bolted to the front of $i t$ ) comes along and does the first leveling. After this it is smoothed down with a grader. The timber in this part of the forest is mostly burned or overripe. The whole project is to save the second growth so that it is not burned. I counted a tree that had 196 growth rings and it was comparatively smal1. One with 250 is fairly common the fallers say. The second growth is only 5 to 25 years old so our crop will not be ready for this generation. If there were roads throughout the forests and people would quit setting fires the fire danger would practically vanish.

There are very few natural fires out here. Mostly light headed natives set them. The big idea of our camp is to keep the [Forest] Service from hiring any local men so that they won't get work if they do set fires.

This is sure a fine place to sleep. I could do it both day and night. The kids have been picking up a lot of petrified wood. It is here by the carload. Wel1 next Tuesday is payday and most of the men are broke.

I just got a package, letter, and card from the folks. Will have to read it so will close. Hope you are all well.

Your Nephew,

Norman Myers

[Editor's Note: The above letter is one of the few which was not addressed to the parents of Mr. Myers. This letter, addressed to his Aunt Hannah, was included as it is the only letter of the series to give a good description of the CCC sidecamp at Fawn Camp.] 
Tiller, Oregon

July 30,1933

Dear Folks -

Well it is Sunday evening again and we will have to work 5 more days. It is sure fine weather up here now. We were above the clouds this morning and it sure was a sight with the sun shining down on them. The clouds then blew over us and it was awful foggy.

I received the letter from Emerson yesterday, his card from Chicago, and your package. I will use the films when I go to Crater Lake and have used some of the thread already. Also read and enjoyed the funnies. I am glad that I am having the Tribune sent as I don't get the papers now like I did at the main camp. The mail comes in rather spotted now every two or three days. Send out the other films and watch though as I will need them. I will probably get to the [Crater] Lake this Saturday or next. I know that dad and Emerson will have a fine time in Chicago and get to see a long remembered ball game. Has Emerson tried to get another job? Has he anything in sight now?

I sure like to get a letter from Emerson. I'11 bet that he doesn't have any better fishing than I do. What was the biggest bass he caught? I will take some more pictures of fish soon as I catch them. I doubt if the scenery exceeds this around here. Mt. Pitt (McLoughlin is the official name) is very pretty as it is a perfect snow cap. Also can see the snow capped guardians of Crater Lake. Did they fish at night or in the morning or evening? I knew Carrol Sohl while I was in high school. Nick Laudenklas is in the picture with me. He just happened to walk along. How did you like the ride in the Pullman?

This afternoon I helped the boss pack some dynamite down the trail about 2 miles to where we work. We used two pack horses and each took three boxes. Then we rode on to a place we have to work on the rock. There is about 100 feet that is 14 feet deep in places to be blown out. It is so steep that scaffolding has to be built to hold the drillers. The work is going fast now and we will get to the rock about the first of next week. All of the road has been surveyed and the stakes are easy to follow. They only clear out a 7 foot roadway here. I believe we will finish the work in 6 more weeks. They have a dynamite which is headacheless now and it seems good for stumps. It resembles black powder somewhat, is dry and made by the Tragon Powder Co. It don't affect me a bit.

Yesterday morning I hiked to Beaver Creek about 4 miles down the mountain to fish. We are located right on the divide between the Umpqua and the Rogue Rivers. The Rogue River watershed is in the Crater Lake Forest [Crater NF, now Rogue River National Forest] while the Umpqua is in the Umpqua [National] Forest. We are located 10 feet south of the divide so I suppose I am in the other forest if that means anything. 
We1l Saturday I followed a blazed trail about a mile to the Tison place, trapper's lodge. A bear trap weighing 25 pounds and with two winches is in it. There I cut down Fawn Creek till I met Beaver Creek. There were just millions of mink tracks there and I even saw one fishing in the creek. It seems darker than the ones in Nebr. There are a few coon tracks, lots of deer though but didn't see one till I was within 200 yards of camp. Then I scared up a big buck. I saw where 3 deer had been killed along the creek. I also saw cougar tracks. Scared up some grouse. I caught 11 trout but they didn't fight like those around the camp. They struck slow and didn't fight any but were 4 times as big. Ralph Young says that was because of the high altitude. There wasn't a man's track along the creek. Coming home I struck out across the ridges and traveled by the sun. In the whole number of miles I only missed camp about 300 yards.

They have fixed up a tent and it contains the firefighting equipment. It is al 1 ready to go even the food. Thursday the main camp was called out on a fire which burned 5 acres. It was the largest so far. Bill Patiedl and Charlie Mead caught a chipmunk this morning and intended to tame it. Just keep the FFG [Fur, Fish and Game] at home and I wi]l read it when I come home. Cecil didn't come yet so I think it was too far to travel.

Well this is all the news so I will close.

Will send 5 dollars Tuesday for expenses.

Lovingly,

Norman Myers

August 1

Dear Folks -

Received raise and am sending $\$ 10$. This is only for this month so won't have one September 1 . At camp now getting pay $\$ 36$.

Norman Myers. 
Tiller, Oregon

August 3, 1933

\section{Dear Folks -}

Well another Thursday has come and it is time for me to write again. The time passes quickly. I received the trout flies (dry), dad's card from Chicago, Mother's letter, and Ruth's the day before yesterday. They sure saw a good ball game in Chicago. Has Mel Harder much stuff? I saw the piece in the [athletic] hash column 41 of the Tribune too. I want the paper sent till I come home as it gives a lot of news. Isn't the fish pond you saw in Chicago about the most complete in the world. I'll bet is was worth the money to go anyway.

Well I will answer Ruth's letter first. I saw Swartz's work on the paper and it looks like his claws. I think that is is a crime that you mention fried chicken. ha. ha. Tuesday we had (Pete UTm, the head boss of camp brought them from home) sweet corn, butter, Lambert cherries and plums. Our regular menu also contained watermelon, mushmelon, and chocolate ice cream. How is the old home place? You hit a poor day to visit anyway. I don't see what would have caused the storm to kill Mrs. Brown's 127 goldfish. I get all the writing paper issued that I can use. Well about the candy, don't send any for a while but maybe you could remember August 27.437

Well Mother's letter was written first but held up so I received it that same day. I just receive the mail every second or third day. It is funny the candy wasn't hard when it got out here. Talking about ferns, the forest is full of them. They are sure beauties too. I don't know how business is and as long as I have this job, don't care.

The chipmunks the kids were training all gnawed out of the box and they gave up training any. There is a new local in camp now packing. He got lost on his first trip as some slum gultion ["meathead"] had moved the signs and turned them around. It is sure a low down trick to play out in the woods. Pete U1m brother and nephew just about burned to death yesterday and he is away from camp now. Another one of his brothers, a federal hunter, was here and showed me a wildcat. He has seven redbone hounds. One is a dead ringer for Joe. How are the dogs now? It will sure be fine when I can hunt next winter. When does the new season on coon open?

We got Tuesday p.m. off to get paid at Camp Drew. They told us to pack up so we tore up camp here and Toaded it on the truck. We were to work at Summit for a few days. Then when we got down here they ordered us back aş Camp Drew was quarantined with measles. There are four cases and Klintworth 38 is one of them. Got 11 dollars instead of $\$ 5$. This is only for this month though but I am glad to get it. When my insurance comes around pay it. The boss is going to give the raise around to all of the crew. 


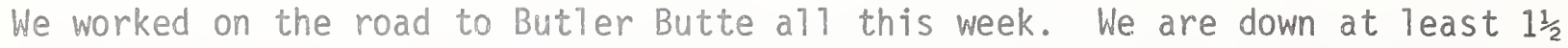
miles already but reached a rock ledge this p.m. and it will slow us up a bit. A bulldozer started in making the road now. Cecil wrote me from Stockton, Cal. and said he was afraid of the road. Don't blame him.

Lovingly,

Norman

41/ A column entitled "Athletic Hash" was a feature of the Sporting Section of the Fremont Tribune. It was written by Sports Editor Herbert $S$. Putman.

42/ William and Virgie Brown were neighbors of ours on the farm.

43/ August 27 th is the anniversary of my birth.

Tiller, Oregon

August 6, 1933

Dear Folks -

It is Sunday p.m. now and I don't have anything to do. I have been loafing al1 day now getting ready to work tomorrow. It is warmer now as it has been very cold out here lately. One day we had what they call the coastal fog and it is what we call rain in Nebraska. There is hardly any news to write now as nothing has happened.

The rock we blasted went well Friday p.m. We always shoot about 30 charges electrically and it makes quite a racket. The front holes on the ledge were about 4 feet deep and loaded with $40 \%$ and the back holes were about 8 feet deep and loaded with $20 \%$. The $20 \%$ is supposed to lift more. In boring and springing holes we cool the hole with water and let it set before we spring again. We use $60 \%$ to spring and $7 / 8^{\prime \prime}$ sticks. Tomorrow we have to take another layer of rock off and so on till be get to the road level.

Yesterday I went fishing again. Caught 14 trout and took several pictures of them. They are a lot bigger here than in the main camp streams. They struck [so] hard yesterday they ruined both of my royal coachman flies. Used grasshoppers some with fine luck. I scared up three grouse and four deer on the trip. Also went swimming in a deep hole with James Scanion of Ceresco [NE] who went with me. While fishing downstream I scared up a fawn about 16 inches in height and an old doe with fawn following her coming back. Scared up another small fawn in a bunch of ferns in the woods and it sure ran away. I just added it up and found out I have caught 116 trout since I started fishing. The steelhead run will be on in September and is supposed to be good. Dry flies are worthless in the creeks here it seemed to me. 
The measles seem to be under control as no more cases have broken out. The ma in camp is quarantined but ours isn't so a truckload went to the dance last night. Three out of our tent got drunk on the mountian dew and have awful headaches now. Had spring chicken, gravy, mashed potatoes, string beans, and apricots for dinner today. Also roast mutton given by Pete UIm, the boss, and it is sure good.

I received dad's letter and the funnies Friday so had lots of reading. How are Joe and Red now? The watch is fine and keeps perfect time. I forgot to tell you to pay Emerson the $\$ 1$ I borrowed at Ft. Crook. Use the other $\$ 9$ to pay for some of my expenses, rod, watch, etc. One of these days I am going to write LMR [Luther M. Roessler]. As soon as I see it in the paper and find out how to spell it. Swartz must be an expensive cat the way he breaks fruit jars. The small grain must have been better than they expected. Uncle Frank must be celebrating by going to Calif. Well this is all the news so will close.

Lovingly,

Norman Myers

Tiller, Oregon

August 10, 1933

Dear Folks -

Well it is Thursday evening again so I will write. I feel fine and sure like our weather. I sliced a piece of my thumb and finger last Monday, but they are healed now. One kid cut his thumb badly with an axe but is getting better now. The measles are out now and the quarantine was lifted yesterday. You do not have to send me [writing] paper as I have more issued me than I can use. The reason I sent home money is that I can't use it out here. Most of the kids are broke already but they lost it on booze and poker. If I kept all the money someone would steal it. We are getting the $W-H$ [World-Herald] now so don't send any more funnies as I see them here. I didn't get a Trib. [Tribune] today. Something is funny. We are supposed to get a trip to crater Lake or the Ocean next Saturday. I hope I get to go.

The man that held us up is in jail at Roseburg now. They took him there last Sunday night. Are they hiring any people in Fremont now? I hope Enerson has as good a luck as Grant getting a job. Pete U7ms brother that was burned died last night. The men at Fawn Camp chipped in $\$ .05$ apiece and are going to send a bouquet for his funeral Saturday. I am sending that watch home as it is no good. It only runs about 4 hours without stopping. I thought it was my fault at first but I found out it wasn't. Don't send anymore out as a watch won't run on me anyway. We probably will have another 6 months of this if we want it I see by the paper. I might sign up again if I think I can keep the coon hunting fever down. Well beer is Tegal in Nebr. now and I see where Snyder celebrated.

I got a letter from Emerson and dad yesterday and also one from Uncle Frank and Russell Heese. Uncle Frank saw Cecil and Verne at Marion's home. Emerson and Dad must have seen a lot at the fair. The thing I notice in the backwoods is that big fish bite like the bullheads in the old creek at home. Why didn't 
you send that map of the fair and the $10 \phi$ store fly. I haven't fished in a lake yet so didn't use the Trix-Oreno. It will be good in a lake I'm sure. We haven't had any tomatoes yet but have sweet corn often. The potatoes taste sour out here. Funny you mentioned it, just send the toothpaste as I need it. Not so often as I won't get the funnies anymore. The only thing I miss out here is basebal1. I sure liked it but must forget it now. I think Launer has the best drop in the Elkhorn [baseball league].

We worked on the road to Butler Butte all week. We are half done now and will stay here till winter. It snows here in October. When we finish this road,

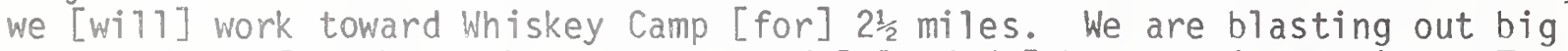
stumps now. It takes a box a stump and I loaded 5 boxes this morning. They are very careful about dynamite out here. The manpower is the only careless thing. There is 1.4 miles of new road passible now and about 0.6 miles are bu17dozed ready for the grader.

Well it is about dark so I will close.

Lovingly,

Norman

44/ Walt Launer was a well known pitcher in the Elkhorn Valley Baseball League for the Fremont, Nebraska team.

Tiller, Oregon August 13,1933

Dear Folks -

It is Sunday night again. I am sending you a roll of film to be developed. The first exposure is of the camp here, the next two of my fish last Saturday, the next of a trappers cabin along Fawn Creek with a bear trap ahead of it, then one of a fall in Beaver Creek, and the last two of my fish I caught today. Also one of a burn. When I was going to take the picture of the falls in Beaver Creek there was a herd of deer drinking in the rapids above the falls. I scared them or it would have been a fine picture.

Last Friday I blasted behind the bulldozer with Pork. Pete U1m, the boss of the road crew, said we did a good job. Friday night I washed and we were supposed to go to the Pacific Ocean Saturday a.m. for a 2 day trip. Then a big fire broke out on Cow Creek and all the trucks had to go there. Our crew was the next to go but they got control of it. Our boss had to go. All of the men were called out of Drew Camp to fight it. It sure put a crimp in our trip. A number of our men [went] to Dick UTm's funeral Saturday afternoon at Canyonville and stayed for the dance at Tiller. Bought all the whiskey in Tiller too. Signed the payroll Saturday morning.

They have had trouble with pack rats here lately taking anything bright. There are also trade rats which trade something for bright things. I went fishing today down Beaver Creek and caught 23 trout. I hope the picture of them is good as some were big. They bit good on the dry hackles today. Used grasshoppers on red hackles with fine luck. Saw where coyotes or couger had killed an old doe. Last week they saw a cougar on the road to Tiller. They saw a coon last night within a mile of camp. I also saw a lot of blue grouse and hooting grouse today. 
Got the letter of yours Friday with the pictures. Emerson must have had a lot of fun in Minnesota. I think I have fine fishing too, at least as good as Minn. Your letter told me the scores 1 day earlier than the paper. I got the films, paper, paste, envelopes, etc. I believe I told you that the last letter. Well the news is all told so I will close.

\author{
Lovingly, \\ Norman Myers \\ Tiller, Oregon \\ August 17,1933
}

Dear Folks -

Well it was 3 months ago today that I was sworn in and half of my time is up a7ready. I had a pretty strange pang of homesickness yesterday when Pete U $1 \mathrm{~m}^{\prime} \mathrm{s}$ brother was in with his hounds and one of them happened to open up. Then they all tore loose and what music. They chased a bear clear up to Devil's Knob. They are all red bone hounds and broken from trailing coon. All they make them chase is cats. Has Emerson found many places where there are young coon already? I will be home in time to hunt if I don't get another job out here. A power company is building new lines out here and may hire me. Ralph Young, our boss, is a boss on their construction crews so maybe stand a chance. Also may get to stay additional time with the Forest Service. It is sure a swe11 outfit to work for. Of course, there are petty jealousies but not as much as I am use to. The major says we have $7 \frac{1}{2}$ days coming in the form of a vacation so may be home earlier than November 17.

I received the trout flies today. Red was up here several days ago and we talked a long time. He says I have caught a lot of rainbow trout but didn't know it. He said that the trout I caught with a line of red spots down the side were rainbow trout. I have caught lots of them. I also received the fly Emerson made and I think I can catch a lot of fish with it, maybe.

I have blasted with the bulldozer all week except Tuesday when I was called back to blast a rock cliff. It was an immense blast when we let it go; 18 shots, and 211 heavy some 5 feet in the rock. Since we came here we used up 4,900 pounds of dynamite, in 3 weeks time. Tuesday evening they ran the bulldozer over the side of the mountain and we had to go out to dig a path up the side of the mountain to get it up.

Red, Fenton, Major [C.D.Y.] 0strom, and Capt. Bryer are leaving soon and [Army] Reserve officers will take their places. Many of the kids are being taken back to their home September 1 to go to school. They are building a new lookout somewhere in these hills.

I will answer Emerson's letter first. I will have to buy a $\$ 151$ icense to hunt and that is too much. Helen must have a fine camp now. Any duck hunting there? Got the [World's] fair map and enjoy seeing it. I am sure glad you got a job. Mother only mailed news except that you were glad the watch was good. 
Got a package today from Aunt Hannah. Candy, Candy and more gum. Also letter from Helen. Sure enjoy it. No more news so will close.

\author{
Lovingly, \\ Norman Myers \\ August 21, 1933 \\ Ti1ler, Oregon
}

Dear Folks -

There is hardly any news this letter but I will write anyway. I haven't received a letter for over 4 days but hope to get one today. I went fishing Saturday down to Beaver Creek with Pork and I caught 26 trout while he caught 10. We sure had a lot of fun. Saw a cougar track in the creek bed but no live deer. I could get them to strike on Emersons fly but the hook was too big to hook them. The other flies worked good though.

I was looking over the Criterion and saw the awful letter. I also learned to spell forest. My hands are cold this morning so it is hard to write. I think several of the dizzy spots are where they couldn't read it. They have posted a notice on the bulletin board that we can have another 6 months if we honestly look for a job and can't get it when we get out. I suppose we can come home for a while then.

I worked blasting Friday as usual. I think that we have to work ahead of the bulldozer today. The weather is fine for working now as it is cool.

Yesterday I went with the truck to Tiller to get a load of powder. When we came close to Summit [RS] a big smoke could be seen near Tiller. At Drew Camp we found out they had 3 fires going on Coffee Creek and 40 men were fighting it. They held our boss and many local men down there to fight it. They haven't called for us so I suppose it is under control now. Well, this is all I know so I will close.

Lovingly,

Norman Myers

Tiller, Oregon

August 24, 1933

Dear Folks -

I have received three letters from you this week so far, so will have plenty to answer. I worked behind the grader blasting up the rocks that they found. I don't like the job as well as loading a lot of holes. I went to Camp Drew this afternoon. After some grader repairs and on the way back stopped at the Ranger Station at Summit. I got a lookout report from the L.O. and am sending it home. It is not filled in but is interesting to read. They have sent another group from Camp Drew to Devil's Flat on Cow Creek to build road. Some say we will all move there as soon as it gets rainy. This is just gossip though. After we passed Devil's Knob coming home 12 men from Fawn Camp passed us going to a fire near Tiller. It was a small one though. 
They took down the names tonight of all the men who hadn't gone to Crater Lake so I suppose I might go next Saturday. I have plenty of film to take the pictures so will snap a number. A fire may call the trip off though.

Has the bank at Scribner opened yet? Do you think it will pay out? The Major left last Sunday and several more are going to leave soon so the Reserve officers can have a crack at managing us. Tuesday evening most of us went to Camp Drew and saw "Oregon Showboat" an educational movie sent around by the Forest Service. I sure felt cheap about the piece in the "Tribune" last week. I didn't tell enough of the story. Pete's brother was burned in a gasoline explosion when he was filling a truck with gasoline at night. He was night watchman of the county road machinery. Pete U7m is a Forest Service boss, not a ranger. Well it was a good story anyway.

I saw in today's paper where Dodge County had a big rain. Hope it helped the corn. The reason fire burns so fast is that fire burns up a mountain fast and then will burn off a snag so it falls clear down the other side of the mountain and starts it $y_{\text {g }}$ both sides of the canyon. Ruth must have had a good time in Omaha. Bill's $\$ 120$ a month sure looks big now. I have you beat at golf as my 85 is pretty good. The No. 8 is a sucker at Fontanelle. Leroy B. [Bíack] told me about all the moving being done now. I received the watch and it sure good yet. Hasn't stopped yet. They furnish us with Dupont [fuse] pliers.

This is all the news so will close.

45/ I do not recal1 Bill's last name. However, this $\$ 120.00$ a month salary in 1933 would have been considered to be exceptionally high.

Tiller, Oregon August 27, 1933

Dear Folks -

Well it hardly seems possible that I am 22 years old today but it just has to be. There has sure been a lot of stuff happen since the last letter. The weather is fine now al though hot and dry. It always cools off a lot at night so sleeping is good. It is so dry that the Forest Service doesn't allow any fuse shot now so all shots have to be made by electricity about 5 in the morning. The humidity is very low now, it runs about 15 to 17 [percent] every afternoon. I found out how to take the humidity test several days ago. I have been a little under the weather lately but it is a stomach ache that has made a round of the camp. One of the tent mates is going to get a Montgomery Ward and Co. catalog so I will order most of the things I need from there. This will cost considerably less than getting the stuff from home. I will send home for some of my stuff I need though as I don't want to have much money on hand as they steal everything here. I won't get more than $\$ 30$ anymore as I think the boss is going to give it to another man.

Our new captain came up today and talked a long time with us. He is a fine man and seems to be trying to help us along a lot. The winter camp is to be on Devil's Flat near Cow Creek. This is 56 miles around the road from Camp Drew but only 10 across the hill, south up to the head of Drew Creek. I am going to buy a map of this Forest if I can from the Forest Service and send you so you can see where I go- They are going to move the mess hall and 
water supply systems over there and eventually all the camp. Before you can reenlist, proof has to be shown that you can't get another job. The job seeking has to be done by mail as they don't send a man home unless discharged. If you want to they will give a man an honorable discharge for asking. What do you think of it? We also get new shoes now and overcoat, pants, heavy underwear, and replacements on all clothes worn out. Then the best is an oversea's hat so we won't have to wear the fatigue hat. Do you think I could get another job in Fremont? Ask Uncle Frank if he thinks I could get one in Omaha? I don't think the method of hunting jobs is satisfactory. The expense of sending all the men home is too much they say. If I stay, I will miss out on coon hunting but am sure to get $\$ 30$ a month.

Last Thursday when we were coming in from work, I told you in the last letter we passed a truck taking some of our camp to a fire. Well in about 10 minutes after I finished the letter they called for more men and I went. It was 9 before we were all packed and ready to leave. We made a fast trip to Summit and then took a truck trail, that I helped repair this spring, about $2 \frac{1}{2}$ miles into the Winters Creek District. This is about $2 \frac{1}{2}$ miles from Beaver Creek. Soon after we left Summit the red outline on the smoke was visible. The fire had been set about a half a mile from the road near a good trail. It was an old burn with lots of flaming stubs 150 feet high sending out sparks setting many spot fires over the line. The second growth fir was about 15 feet tall and very thick so it burned up instantly on being reached. The fire line had mostly been made when I reached the scene at 12 but we had to patrol it and put out snags or fall them. They sure had the snags falling. I had a bucking saw to work with for a while. Then a hazel hoe, and at last a water pump can. They didn't work the men as hard as we use to on the farm though. Our shift was called off at 7 in the morning and we arrived at camp at 11. They called reinforcements from camps at Steamboat Springs 50 miles north of Roseburg up the N. Umpqua, and Wolf River [Creek] to help us hold it during the heat of the next day. 50 men came from every camp, the SSCCC's [Steamboat Springs CCC] are [WWI] veterans. The fire covered 5 acres the ranger said bordered on a serious one if it had spread. It is going out now. It happened a couple high officials of the [Forest] Service were here visiting us then and were on the scene of the fire. I like fighting them and will go every time I have a chance. They set up a kitchen at each fire to cook for the workers and a telephone line is quickly laid out so the camp can be notified of the fire's progress. I wore the watch all through the fire and it kept good time. It is alright I am sure.

I went to Crater Lake today. We left early this morning, ate breakfast at Camp Drew, and left there at 8. The road to Trail is poor but from Trail to the Crater [Lake] is oiled gravel and is fine. We arrived at the lake at 11:45 and ate lunch. Then I climbed down to the water and back up. I took 10 snapshots of the lake and 2 of the natural bridge 11 miles from the crater at the Rogue River. The atmosphere was too smokey to take good pictures. It is sure a wonderful sight. They say that we are going to the ocean for sure now. We could see Klamath Lake plainly from the rim [of Crater Lake]. I hope all of the pictures are good. There is a lot of snow up there now.

I received the card, paper, and candy tonight. The candy sure tastes good. Never passed through a town today. We11, this is all of the news. Cold and cloudy now. It is awful late anyway. Got new pencil and film.

Lovingly,

Norman Myers 
Tiller, Oregon

August 31, 1933

Dear Folks -

Well August has finally been squeezed out and tomorrow the eagle (shits) as the men all say. It surely has passed quickly. I am sucking some lemon drops that you sent out for my birthday. I kind of have an idea I will stay some more out here [enroll in the CCC's]. I certainly like it. I also like coon hunting but business comes ahead of pleasure. How are the dogs? Did Emerson find many coon tracks last Sunday? How is Emerson's job now? What does he do? I will have $7 \frac{1}{2}$ days in vacation coming if I don't go back this November and can go to Portland and spend it. Look for a job, what you can but don't worry about it. If I spend some more time out here the experience will be valuable.

I have been working blasting with Pete's crew this week. Yesterday and today I shot a ditch out of solid rock for a culvert. I mudcaped the rock to spring a seam today with 50 sticks of $40 \%$ and it opened one up about this wide. / / Then worked powder in and it sure broke it up. The rock along Beaver Creek is awfully hard. Saw Major 01strom's letter in the paper and it kind of put a boost for me. I think that the letter was the best written for the paper yet.

I probably won't send any money home tomorrow as I am going to loan Patiedl $\$ 5$ to help him buy a jacket (leather) and he is sure to pay. I need a little money as I ran short last month. They are going to take some of the men on a trip to the coast this weekend. I will probably celebrate by fishing in Beaver Creek. They fired our cooks yesterday and sent up two new ones. Never told them even what was wrong but just canned 'em. The weather is cool now and we have put up the stove in the tent. Everyone seems to be getting cold sores now and I am one of them. I sent the pictures home yesterday so you should have them already.

Our bulldozer is broken down so the work is going slower than it should. The light is awful here so the letter should be worse. Received a letter from Cecil today and it was sure good. I am enclosing several clippings about fires. The sky is so smokegy you can't see the big mountain now. We are a long way from the big fire but it sure has made the atmosphere smokey. Has Emerson been fishing lately? I received his letter just the other day. It is about dark so I will close.

Lovingly,

Norman

47/ This fire was named the Tillamook. It was one of the largest ever to burn the Forests of Oregon State. The newspaper article stated several thousand CCC members were fighting fires in Oregon at that time. 
Well it is Sunday night again and I have rested all day. This is certainly a stil1 place to stay except the constant ring of horseshoes. We are all getting to be experts here now. It is the only sport they have here now. The basebali spirit has entirely died out. There is surely a good race in the national league this year and I hope the Braves win. It also looks as if Snyder has some chances in the Elkhorn league too. Last Sunday's games sure tightened the race.

Last Friday morning I blasted a few stumps and rocks that the bulldozer was having trouble with. We had to quit work at ten to have early dinner and get our pay. I got eleven dollars again and am going to save it out here. I will soon have enough to go somewhere on my vacation. It only costs $\$ 12.50$ for a round trip ticket to San Francisco and $\$ 4.50$ for a ticket to Portland. These fares are very cheap. I think I will have a safe place to put it in the Co. [CCC Company] Treasury. I think I will sign up again. I sure like it here and am going to find out how to enter the Forest Service. It would sure be a good job. The going to the forestry school they say helps a lot. I will have enough money in a year to go for a while and during the long winter evening study. Friday evening Lad Fayman of Clarkson received a telegram that his brother Albert died in Clarkson. He is not going home to attend the funeral al though the government would pay the expense.

Saturday Patiedl and I went fishing on Beaver Creek again. We went down a trail from Devil's Knob. We found a pretty waterfal 7 about 70 feet high. Three deer were standing near the bottom of it. Two bucks and a doe. There is no timber left there as the Big Beaver Creek burn in 1929 killed it all. I caught 19 trout and Pork got 11 . Caught 1 big rainbow and saw one whopper but he saw me first. Got home after supper but the cooks fed us anyway. We fried the fish then and ate them. Then Pete [U1 $\mathrm{m}]$ brought in a bucket of ripe prunes and we ate them. They are sure good. Then we ate 3 watermelons he brought up. He also gave us a lot of comatoes.

They took many of the men on a trip this weekend. A fire broke out while we were being paid and they got control of it quickly so it did not interfere with the plans. We just heard something very sad this p.m. and that is the Chief Steward, Dale Buckley of David City was killed when he fell over a cliff at the shore. There is nothing definite about this. I hope I get to go.

Did you pay my insurance premium? It is due about now. The watch still runs we11. No fires to speak of now but one may break out anytime. They do not
use dynamite to fight fire. No more news so will close. We don't have to work tomorrow.

Lovingly, Norman Myers. 
Tiller, Oregon

September 6, 1933

Dear Folks -

Just last night I signed up [with the CCC's] for 6 more months. I figure I am sure to have 6 more months of work and you can keep your eyes and ears open so if I can get a better job I can come back. It has rained the last day or two and is very miserable weather. This put a crimp in the fires for now and cleaned up the air fine. I could see Mt. McLoughlin and Mt. Shasta plainly from Butler Butte today. If the weather should get unbearable I will be able to come home anytime, anyway. We had to decide on 24 hours notice whether we were going to stay or not. I thought it wouldn't be before the middle of 0ctober. Charles Mead and Bill Pateidl are going back as are about 60\% [of the men]. Those that signed to stay wish they were going and vice versa. They are going to leave September 14 or soon after for Fort Crook and finish their term there. I am going to enclose some money for you to deposit as Pork is not going to borrow any and it is safer there. $\$ 8.00$.

I have heard a little more of Dale Buckley of David City. He died of four fractures of his head, both legs broken, arm broken, ribs broken, and neck broken. Also I believe the back. The coroner declared it was caused by intoxication. They found his hat and a half pint near a tree just above the cliff and $\$ 30$ in his pocket. He had scratched the ground up a lot trying to hold himself where he started to fall the 60 feet. They are not going to give his parents the insurance as he was drunk. The ocean trips are going to be taken anyway so I will get to go.

On Labor Day, I went up to Butler Butte in the morning and sure had a good time. A fire was reported to the office at Tiller by the Windy Camp LO and it was burning on Coffee Creek. Al Barrow, the lookout, showed me a lot about the lookout's job and I took a picture of the fire finder. Also several others. The sky was smokey so the pictures are probably poor. I saw real wolf tracks in the path when I came back. I got a map (highway) of Oregon, map of the Umpqua National Forest, and several other interesting pamphlets I am sending in a big envelope. I am sending a roll of film to be developed.

At three in the afternoon we had a call to go to the fire so I went. Ate supper at Drew Camp and on from there in the fire truck. We started up the canyon at 7 and [walked] stumblingly up it for 2 hours getting there. Then slept ti11 11:30, had lunch and went on duty. There was 1ittle that we could do as the trench was all made and only a couple of snags to fall. Loafed till 11:00 a.m. and ate dinner on our way back at Drew. I saw a large number of miners panning gold along the creek. A7l they get is gold dust. In ' 65 over $\$ 4,000,000$ worth of gold was taken from there. Had today off but worked this p.m. and will get it off some other day.

Charley Eckert is the cook at the S. Umpqua Camp now. It is rather cold here now but I feel fine. We will move from this camp by the 20 th of this month they say. Well the truck has gone so I will mail the stuff tomorrow and can add some to my letter. Received your last letter September 1, yesterday.

Lovingly, 
Thursday evening. I forgot to tell you that all of the powder crew was transferred to Camp Drew except four and I was one of them to stay. I have Pete U1m for a boss now. Heavy frost this morning. Could see Mt. Shasta plainly today. Doctor was up today and said that those that signed to leave may get a chance to sign up for 6 months in Tennessee this winter. Wel1, I will have to close.

Tiller, Oregon

September 10,1933

Dear Folks -

Well we worked overtime Saturday morning and finished the blasting on the Butler Butte - Bald Ridges road. The bulldozer is through to the other end too. They will finish grading it in another day or two. I don't believe that it can be more than 40 or 50 miles to Crater Lake from Fawn Camp by this road. It is not a real road as they call it a truck trail, however, it is just like a 11 mountain roads. They say that the side camps are all going to be pulled into Camp Drew Tuesday and that the men leave for Fort Crook next Thursday. Pateidl and Mead say that they may see you sometime when they are in Fremont. They will be there by the Sunday after next if the plans hold out.

I haven't done any fishing this weekend. I will be camped on Cow Creek this winter so will have good steelhead fishing they say. To fish the big steelheads in the Umpqua they say it takes a casting rod, a 250 foot [capacity] reel, and a lot of strong line. They use salmon eggs which I will buy out here for bait. They say they are the scrappiest fish out here. I have a day coming so if I can get it and move to Drew Tuesday I am going to fish in the [South] Umpqua the last of next week. Grasshoppers seem to be the best bait now.

Ames sure didn't play good ball at Fremont on Labor Day. Donald Sic sure made the errors too. I never thought he would do it. It looks like Snyder may get into first place yet. 48 [0rval] Diederichs must be pitching good ball for Fremont. I hope Vern - beats Fremont too. I saw the accounts of the deaths in the Fremont paper last night and also in your letter I received Friday.

I see where they are having a lot of trouble in Cuba now so may get to go there. It had a piece in a local paper saying that themen going back can go to Tennessee. Maybe I shouldn't have signed. One kid -9 put on spurs for fun today and topped a big fir tree. I took several pictures of it. Well this is all the news so I will close.

As Ever,

Norman

48/ Vern Voegeler from Snyder, Nebraska was a well known pitcher in the Elkhorn Valley League. He later pitched a number of years in the Minor Professional Basebal1 Leagues.

49/ 0iie Lynch topped this tree. 
Tiller, Oregon

September 14, 1933

Dear Folks -

The weather has changed a lot here lately. It rained all day today. They call it the coast fog blowing in but it is like our old cold rains in Nebraska. We went out to work this morning and it was sleeting around Butler Butte. I'11 bet the snow capped peaks will appear all around soon. I got soaked this morning packing tools up to the road from the Whiskey Camp trail. We got orders to quit the road to Whiskey Camp trail this morning as they think the rainy season has set in. When we came home in the truck this noon we brought in Al Barrow's stuff from the [Windy Camp] lookout as he is ordered in so the fire season must be over. The bulldozer, the caterpiller, the ripper and the grader left here for Drew to work on the road to Diamond Rock. The roads are very muddy now and we may have trouble getting moved. I believe the whole camp will move in a few days.

We finished the road so a car could travel on it to Abbott Butte and beyond. Monday I had to go to work at 5 and work till 4:30 blasting rock so the bulldozer could get around the last mountain (Bald Ridges). I tried to get pictures of Mt. Shasta and Mt. Pitt from the peak at Bald ridges but I don't suppose they will turn out good. I sent the roll of film home Monday night. I will get more pictures this weekend if I go to the coast as they have planned to take us this Saturday. The weather may prevent the trip this week. Tuesday we started to move on the Whiskey Camp road and completed about 2 miles and had a mile to go when the rain came making us quit. Pateidl and Mead quit work Tuesday noon and went to Camp Drew. Tomorrow they will leave for Ft. Crook on the train. I believe they will see you sometime in Fremont. Tuesday night they had a farewell banquet for them.

Are there very good crowds at the fairs now? Is there much train travel to the fair in Chicago? I have been reading a lot about the fairs and ballgames and I suppose there is plenty of entertainment. Ames sure lost a couple of games. You can just keep looking for a job and tell me if you find one. I can come home at any time if I have proof of a job. I believe the weather will not seem so wet when we get our high top leather shoes, rubber pants, coat, and hat.

I feel fine now as the weather seems heal thy even though wet. I received your letter Mother last Tuesday. Funerals seem to be the thing in Fremont now. The Marck boy did not like it out here. There are no flowers up here now. Maybe there are some earlier in the spring. I haven't been fishing lately but will go the first time I have a chance. 
Tiller, Oregon

September 17, 1933

Dear Folks -

I received Dad's letter Friday when I came down from Fawn Camp. I have moved in from there to Camp Drew as no more powder work will be done there this year. It has rained all day Friday, Saturday a.m., and today. It is raining now. It will be wet working tomorrow I think. It sleeted quite a bit today. You said that there is a lot of fallen timber in Washington forests. In the good timber around Fawn Camp there is no underbrush or fallen trees. Only a carpet of ferns about a foot deep and the ground [which] doesn't have a single small tree, also is dark. We often hear partridges in the woods, anyway, if you scare up an old hen [she is] with her family. We didn't have to work fires as it rained the roads out. I am sending a roll of film to be developed. I want the negatives of the caterpiller and grader to give to a kid out here if it is good. The rest of the pictures taken at the coast are poor, I suppose as it was cloudy.

I got to go to the coast this weekend. We left Camp Drew at $8 \mathrm{a} . \mathrm{m}$. in two trucks for the ocean. Went to Canyonville, north to Dillard, went through Coquille, Marshfield, North Bend, to Cape Arago. The mountains are much lower over beyond Roseburg than here. Also poorer timber mostly burned off. I ate all of the prunes I could hold in one orchard, peaches in another, peach plums that Verne Poole got us (a foreman) and pears. Dillard is a great fruit country and also melon and berry (Alaskan blackberries). They are as big as one's thumb.

We arrived at Sunset Bay at 1 p.m. and ate dinner at the camping ground. It was about 200 yards north of here that Buckley was killed. The Pacific shores are very noisy as the waves roar as they come in against the rocks. Cape Arago was about a quarter of a mile away so I got to go through the lighthouse. The light has 270,000 candlepower and has wonderful lenses made in Paris. I saw the tramp freighter "Phyliss" come into port while we were there. Marshfield is a rather big port. Toward evening while at the bay I saw the tramp freighter "Barbara" arrive. The lighthouse also has two large fog horns. We had supper there. Saw many seagullis and ducks.

At night we made our bunks at the legion hall at North Bend. First we went a 11 around North Bend and saw nothing there. Went to Marshfield. Watched them using immense booms loading and unloading the boats. They held 1,500 tons and were open except for the cabins. They ply between Seattle and L.A. and have Swedish crews. I went to the movie and it was good. The town seems awfully hard hit. Slept well and got up early to go to Bandon. Good beach there.

Got home tonight very tired. Will close.

Norman Myers 
Tiller, Oregon

September 19, 1933

Dear Folks -

Did you receive the letter and eight dollars I sent you about the 5 of September?

I mailed the letter, brown envelope, and roll of film the same day. Emerson in his letter said you received the maps and film but didn't mention the money. Neither did you in the letter I got from dad today. I kept the money about a week and was afraid somebody would steal it so mailed it in the Fawn Camp box. If you haven't received it, sent a tracer after it from the Fremont P.0. and tell me.

The deer season opens tomorrow as the country was full of hunters today. I'11 bet we hear a lot of shooting tomorrow. There is a big farewell banquet Thursday night for the men that are leaving. The menu is venison, venison gravy, mashed potatoes, creamed peas, pumpkin pie, sliced pickles, and cigarettes. They don't feed the men as well down here as at the side camps. As they get the Tribune at the library here, and I can read it every day, you can stop my subscription.

I worked on the road to Summit [RS] today and the Diamond Rock road yesterday. We are blasting stumps altogether now. I loaded 46 this morning the best I have done so far. I believe we will work on the road to Summit a good month yet till we move to Cow Creek. The men leave for Ft. Crook Friday morning so the manpower will soon be short.

I suppose that you thought my letter written Sunday night was dizzy but I was awful tired. There are many strange fish and plants along the ocean here. Most of them are brightly colored. I saw many starfish. I would love to just go along and pick up the rocks and shells if I had time. I bowled in Marshfield that night and lost every game. Sure a fast way to go broke. $25 \&$ a game is what they charge there. The towns seem very hard hit out here. In Empire, 9 out of every 10 buildings are empty. Lots worse than in Nebraska. Fine buildings too.

I saw some big steelhead in a window in North Bend. They are the same fish I have been catching. Some would weigh 5 pounds. Received Emerson's pictures and letter yesterday. I sure like his letters. Send some good film soon. A roll is enough. Dad's letter mailed Saturday came Tuesday, pretty fast.

A ticket, round trip, from Portland to Chicago good in Pul1man is $\$ 50.50$. Pretty cheap. They charge $2 \phi$ a mile for all local travel out here.

We11, this is all the news. Won't write till next Sunday so it will be quite a while after this letter.

Lovingly,

Norman 
Dear Folks -

I received your letter yesterday noon and enjoyed it. I feel fine except for being wet all of the time. It has rained every day since it started. It usually quits about noon and starts in again at 4 or 5 . I have just layed around today in the dry hoping it clears up by tomorrow. They say it won't clear up till spring though. We are getting fine cooking now, had strawberry shortcake for dinner.

The 93 left for Nebraska early Friday morning. Pateidl, Mead and Klintworth are all returning. They sure were a wild outfit when they left here and probably will be wilder when they get back. I suppose they will be turned loose about the first of this week. There are about 48 in camp to eat today. Many are home as most of the locals leave every weekend. Do you think the new enlistments in Nebraska will be sent out here to restore this company? They have not started to work on the barracks at Devil's Flat yet. I think they will have to start soon if we are to move there.

I have been blasting behind the bulldozer most of the time now. Friday I was teamed up with an old powder monkey from early times. He keeps a roll of fuse around his neck all of the time. Smokes cigarettes while he works. Carries a gun, knife, and flashlight all the time. I sure liked his line, but told him and the boss if he smoked on the job I wouldn't work with him. He said if I didn't stay with him he would shoot me. (Jokingly). I told both of them that I preferred to go home on the cushions and not in a wooden kimono.

I went fishing yesterday on the [South] Umpqua between Tiller and Mi10. Caught eight trout and one chub. I caught the chub (yellow) on the trixoreno but it rained all the time so it wasn't much fun. I had a couple of big fish (2 foot long) strike on the Trix-0reno but couldn't snag them. I believe the fishing, except for steelhead, is about over if it continues to rain. I caught 194 trout this year. It certainly was worth the 1 icense.

So far no one has been killed hunting here but one man [was] thought to be 1ost. The airlines which flies overhead has a $\$ 500$ reward out for the finding of the plane which was lost in the early part of June. Hoping some hunter finds it I suppose. We had our farewell banquet Thursday evening and had venison, gravy, mashed potatoes, creamed peas, pickles, hot rolls, butter, and pumpkin pie. Freddie Brown, an Indian, killed the bucks. A doctor from Medford came in with 2 bucks and also said he killed an old black bear with her cub. I wouldn't brag about it if I were in his boots. They killed a number of other bucks at Fawn Camp. Perry Fields, a cat skinner, killed a coyote and bobcat the first day but no buck. One local was lost al1 Thursday night but camped out and came in Friday a.m. I helped look for him that night and all the old heads got lost.

I believe the fire season is over now. They have stored all the equipment. I spent a lot of time today reading a book on forestry. It is interesting. You can send me the Fur-Fish-Game sometime when it is convenient. Well, this is all the news so I will close. 
We11 I signed up for another six months terminating March 31, 1934, tonight. The contract is the same as the first one. I hope I can get work back in Nebraska though as one gets a stomach full of roughing it. I don't want to come back if there isn't a job though. I sure wi 11 miss the hunting and it is too expensive a sport here. They killed another deer this week and fed us. It is certainly fine meat. There was a lot of agitation about going home this week, but I don't think they will let anyone go. About 40 of the 70 some remaining signed to go back to Nebraska but the only thing that was done was to send the chief agitator home with a dishonorable discharge last night. I figure when I get out next March 31, I will have $\$ 267$ (Don't tell any of this going home business)

The weather the last two days has been fine, but it started raining again tonight. It just don't seem to be able to clear up and I don't think it ever will be able to till next summer. I am still plugging away on the powder crew. I have been bull-pricking lately and I don't mind it a bit. The boss is passing the $\$ 6$ raise to another man this month so it will be the last I see of it I believe. Well, it is only $\$ 6$ anyway 1 . I am going to get some experience blasting bedrock where a jackhammer drills the holes soon. We have about 150 feet of solid stuff. Some of the holes will be about 10 feet deep. We have about $3 / 4$ of a mile of blasting and the road to Summit will be complete.

The doctor here seems to he the main physician in this community. Every once in the while some hillbilly comes in and has his ailment treated. Last Monday a man came in with a broken arm obtained in a fight and had it set.

They issued us our overseas hats and leggings this week. The leggings are like we used husking corn last year. I feel fine now but have a cold coming on. Would you sent the negatives of all the cat or grader pictures I sent home? The cat skinner wants them. I received the two Criterions the other day.

I received your letter Tuesday which contained the pictures and card. The card sure had a strange address. I would hate to see Reddie $52 /$ go although it couldn't make any difference now to me. The pictures were sure fine, especially of the dogs. No more news so will close.

Norman Myers.

50/ When I finally arrived home in 1934, the money sent home had been used by my folks to live. Actually, that was the intention of the CCC program.

51/ Although I had been advised by the foreman that the raise was going to be passed around to other men, it was not done. However, it was dropped for a period of time when I was being trasferred from this company.

52/ Reddie was the old coon hound of my brother's. Red was so old he was getting feeble. 
Well it hardly seems possible that we get paid tomorrow but it is true September has surely passed quickly and I suppose the rest of the months will too. Six months is a short time anyway and that is when the next hitch is up. In lots of ways this is a fairly good job and one can save $\$ 25$ a month. I am going to keep my $\$ 5$ I get this month as I need several things. I am going to sent to M.W. \& Co. [Montgomery Wards] in Portland for them. However, keep the weather eye out for a job and telt me if one turns up.

It is Indian summer weather now and as near a perfect climate as is possible. Crystal clear, warm in the middle of the day and cold at night. I have been laying around all day and feel awful 1azy. One certainly gets plenty of rest here. It would surely be fine squirrel hunting weather. Some of the locals are out today hunting deer in order to supply the camp with some venison.

I suppose the men should be back in Fremont now that left here. I am glad that I stayed as a job is worth a lot now. I hope that you got to talk to Pateidl and Mead. I see by the paper that most of the men in the camps on the west coast have left for the east.

I went fishing in Elk Creek below the camp yesterday and caught 16 trout. They were a lot smaller than the ones caught on Beaver Creek. I received all the negatives of the cat and grader I want and traded for a negative of lighthouse at Cape Arago. Well the World Series is about to begin. One almost forgets baseball up here in the canyons. No one even plays catch. No place to play football either. Fishing and hunting [are the] only possible sports. If this weather keeps up I will fish quite a bit now.

I received your letter Friday. I was sure glad to hear that the money arrived all right. Well this is all the news so will close. Ask Uncle Frank sometime if there is much of a chance to find work in Omaha for a lunatic who is in Oregon now.

With Love,

Norman

October 5, 1933

Dear Folks -

I received Emerson's letter last Tuesday and it had been missent to Trail so it was a day or two late. The weather is hot and dry now. It cools off in the evening some but it has made the fije danger greater. I feel fine now but have my first powder headache tonight? I weighed myself up at Drew the other night and weigh 173 pounds with little clothing. This C.C.C. must have agreed with my health. I weighed in at 149 pounds at Ft. Crook. The geese are flyingsouth by the thousands so winter must be coming. I have written to Floyd -3 and received an answer He is trying to get a job plumbing in K.C. [Kansas City]. He was still working with the telephone co. then. Also, I think, considering getting married. I also received the Dodge Criterion and the film yesterday. Have you talked to any of the men that returned yet. 
Got paid the other day and received $\$ 5$. I won't need all of it so I will keep it for a rainy day out here. If you can find the film of the natural bridge send the negatives out. It is a white river running through a rock cavern I took coming back from crater Lake. It is the Rogue River but is so swift it is narrow. One man was sent home this week for being drunk and disorderly. They certainly try to discourage drunkedness. They are to hold a big dance for us boys in the mess hall next Monday night. They are getting an orchestra from Canyonville. They say we may all move to Devil's Flat next Tuesday.

They have hired 15 outside carpenters to help build the barracks, bath house, recreation room, drying room, and mess hall. The kids that have been over there say that it is a fine place to live. It is a lot more level than this camp. There is not a half an acre of level ground at Camp Drew. I suppose that we will move there soon. They are rapidly completing their work here now.

Monday we blasted stumps on the road from Summit. Tuesday we worked at the same job. I loaded 113 stumps all day Thursday. I got started at 9 a.m. and had 80 loaded by $12 \mathrm{~m}$. I used up 11 boxes of powder and lighted my half of them too. I don't believe I robbed Uncle Sam out of $\$ 1$ that day. Wednesday they brought out an air compressor to drill rock. The compressor is a LeRoy mounted on a McCormick Deering tractor. It has about 50 feet of pipe and about that much hose. The jackhammer is like the riveting hammer. The drills are hollow and have four prongs on each end. The air goes through the pipe and forces the residue out. The drill turns constantly while being hammered.

Then we spring it with rock dynamite. $40 \% 7 / 8$ inches diam. First with 1,2 , 4,6 sticks. The cavity holds about 25 pounds of dynamite which we load them with. We shot them tonight and it certainly broke up the rock.

I went to a fire last night with Verne Poole and have $1 / 2$ day overtime coming. It was on the Joe Hall Creek. Not much work just told stories. Another one [fire] going tonight on Deadman [Creek].

Wel1 I just got a goose (wild Canada) for a mascot. Ralph Young caught him up the road when his car lights blinded it.

Fire! got to go.

Lovingly,

Norman Myers.

53/ Floyd Black was a neighbor when we lived on the old farm and he had moved to Tonganoxie, Kansas. 


\section{Dear Folks -}

I have layed around all day resting up from the fire. We left here Thursday evening at 8 o'clock. At Tiller they gave us some more provisions and the fire tools. The fire was over near Deadman Mt. We went up the road along the South Umpqua for about a half mile and then up a road to the end about 4 miles. We had to hike to Windy Camp. There we located the fire from the lookout as the lookouts (men) have all been pulled in. We left the camp at 12:30 a.m. and walked past Red Top Mt., Deadman Mt., and Quartz Hill to the fire. We first saw it at $5 \mathrm{a} . \mathrm{m}$. and arrived there at 6 . Built a camp spot and Ralph went to look the fire over. It was about 30 acres he said. The rest of the crew (22 men), the pack mules, and equipment came about $11 \mathrm{a} . \mathrm{m}$. Had dinner and went out to fight it. We started trenching at the head and back firing. We came in a 6:30 p.m. with it all trenched. It only jumped three places that night. The short wave radio they sent out so we could call them didn't work so Ralph walked to Windy Camp and back that night to call the Ranger. He came back and said the Veterans camp was sending in men to relieve us. The men arrived at noon Saturday. So we went back. These W.W. [I] veterans are certainly getting old. We hiked back by 4 to the truck and got to camp by 6 . Took a bath and ate supper and went to bed. I went to a fire Wednesday night and got to bed 1ate. Was up at 6 Thursday and never slept till 7 p.m. Friday 37 hours. The fire covered 115 acres before controlled. If it don't rain soon the fire season will be called again.

Received Dad's letter Saturday when we arrived at camp. Feel fine and have been having fine weather. The goose Ralph gave me got 1oose. It $t_{5}$ yqu dn't eat so the Sergeant turned it loose. What does Emerson do at Cranes? What are his gpyrs? I see by the paper that NY has won 2 and Whitehill shut NY out once . They don't play anything here now in the line of sport. They say we may be moved to Cow Creek this week.

Well this is about all the news so will close.

Sincerely

Norman Myers

54. My brother Emerson's new job was at Cranes Auto Supply Store, Fremont, Nebraska.

55/ On Dctober 6, 1933, Whitehi11, pitching for the Washington Senators in the World Series, shut out the New York Giants. 
Anchor, Oregon

October 12, 1933

Dear Folks -

We11 is is Thursday again. I received your letter last Monday. You needn't worry about me bumming my way home on RR as I won't be back unless I have a job awaiting my return. Sometimes the nights seem long but it is because there is nothing to do.

I was moved to Cow Creek to help build the camp the day before yesterday. 15 were taken to Ft. Riley, Kansas yesterday morning to start up a new camp. There is no Co. 754 now and I am a member of Co. 757 of Myrtle Point, Oregon. This is just a side camp of [the main Company $757 \mathrm{Camp}$ ] and I have never seen the main camp. Camp Drew is deserted now. When you mail me the letters address them Norman Myers, Cow Creek Camp, Anchor, Oregon. Would you renew the subscription to the Tribune and have it sent to the new address immediately as I haven't gotten to see a paper for three days? I don't believe they will have any papers from back home in the winter camp. I will write you when I change the address again.

I see in the paper that 41 men want to get in the CCC's and the quota is only 3. This shows that the depression is not entirely over yet. The business is picking up considerably out here now. I can't help but think that Oregon is going to become one of the best states to live in when the boom comes. I hardly believe I will hunt this year as I can fish whenever I want to. I hardly expect to get any of the money from the bank 36 . It will go like the war debts. I am working handing the lumber up to the carpenters now. I don't have to work hard. I am working till 5 o'clock now so the two shifts can work together.

They are putting up the barracks fast now. We have one of the barracks nearly completed now and the mess hall and wash houses about half done. There are to be 4 barracks, 1 mess hal1, 1 bath house washroom and drying room, 1 garage, 1 administration building, 1 wood house, 1 medical house, and 1 latrine. We have a Koeler electric light plant for the camp and there is to be a water system.

The Cow Creek is about 4 times the size of Maple Creek and is about the finest fishing in Oregon. I saw the first cutthroats yesterday. Also many coon tracks along the banks. I am going fishing next Saturday. The timber here is about all white fir and pine. Also quite a few knob [cone] pines. It is about 2,200 feet high here. There is a mountain that runs up beyond the camp about 800 feet.

They are going to have a dance in the mess hall next Monday night. The one last week was a great success. I didn't go though as I can't dance. There have been no fires lately.

Well this is all so I will close.

Norman Myers

56/ Prior to the financial crisis in 1933, I had about $\$ 100.00$ in the First National Bank, Scribner, Nebraska. Several years later, 50 percent of my deposited funds were returned wi thout interest. 
Anchor, Oregon

October 15, 1933

\section{Dear Folks -}

I received Mother's letter the day before yesterday. It is still fine weather here now. They have issued us two more blankets so we are sure to keep warm. I had a piece of tar paper over me for a while so I wouldn't freeze. It is freezing very heavy here every night. I received a letter from Aunt Hannah and Helen yesterday. The people out here do not go so mugh for any kind of hunting except deer. It is certainly too bad that Elmer $=$ had to lose his boat. I sure would hate to spend 2 weeks hunting ducks. They sure taste awful. One thing about me staying is I am saving a little monej 3911 of the time. I know Paul Anderson we 11. Also Hosey (Harold Corcoran) 28 who works in Beemer and Beemer's. One thing I know is that if I came home in two weeks I would have been fretting about a job again.

This morning I climbed a Mt. [Castle Rock] just north of camp. It is about 3,000 feet high. I took a picture of camp from it. I have never seen as many knob [cone] pine as there are here. Maybe I forgot to tell you that there is sections of Cow Creek that are wholly manzanita, an underbrush. The soil here is 211 rotted granite and never gets wet. I caught a bunch of grasshoppers for the fishing this afternoon up on the mountain. I also did my washing this morning. It sure dries out in the heat of the day quickly here.

This afternoon I went fishing up Cow Creek but only caught 4 small trout. They don't bite here like they did on Elk and Beaver Creeks. I believe salmon eggs must be best now. I am going to get some the next time I go to town. coon hunting would sure be good along here. There are tracks everywhere. There was a fire call this afternoon for 25 men but most of the camp had left so we didn't have to go.

We are coming aiong well with the camp. The mess hall and one barracks is nearly done. Another barracks and the bath house have the frames up. I am still carrying lumber for the carpenters. I am working till 5 every night now as the carpenters don't quit till then and they need the help. Yesterday I helped build the latrine and may get a day off for it. I am taking care of the horses this weekend while the boss is gone and getting a little extra change for it. It sure seems fike old times to be currying the old bay mare. They are all about like Daisy.

We are going to move to Camp Remote as soon as this Camp is completed. The address is Myrtle Point and is near Coquille and Marshfield. The mail goes through Marshfield on the way to Myrtle Point. I believe the Co. number is 757. Our eats all come from Melrose near Roseburg.

Well this is all the news so I will close.

With Love,

Norman Myers.

57/ Elmer Lundstrom was my mother's brother.

58/ Harold Corcoran was a member of the original CCC group leaving from Dodge County, Nebraska.

59/ We had a mare named Daisy on the farm. 
Anchor, Oregon

October 19, 1933

Dear Folks -

I am still at Remote [Anchor] working on the [Devil's Flat CCC] camp. For the last two days I have been excavating with a shovel for the water supply tank. The rock is decomposed granite and is hard till biasted. Then it crumbles so much it is easy to shovel. The supply tank is 18 feet in diameter so it is easy to see there is a lot of dirt to be moved. I have worked a little with the plumbing too.

Tuesday I helped put up the 3 horse F.M. [Fairbanks Morse] engine and the centrifugal pump. We certainly had a lot of trouble with the pump. It would cut out every time the pressure was too great. We finally found that the side of the pump (malleable iron) was springing out and letting the water past. I guess the pump wasn't made to force the water that high. I don't think much of a centrifugal pump. They want lots of water here so in case of a fire they are safe.

The camp work seems to be coming along slowly. I believe it will be a month before the buildings are finished. They have the framework up for 2 barracks, foundation for another, mess hall and 1 barracks nearly finished. They have a new Koeler light plant ready to put in. The job of running the light plant and water system would be good for the winter if I could get it.

They have had a number of fairly bad fires lately but none got away from the men. I never had to go to any fires though as we had to get men in from other CCC camps. Camp Number 1305 is to be 1ocated here they say. A11 of the Nebraska men are to go to [the] Remote [CCC Camp], though, next Tuesday for sure. The men that are moving into here are from a camp at Baker, Oregon. They eat off of plates and have butter three times a day. They also say they have fresh milk for breakfast every morning.

I am going to go deer hunting this weekend if the Lord is willing. I know a couple kids that are going to hunt Saturday and I am going along. I am going to fish some more too. We had a dance again Monday night and had a good time. They served sandwiches, cake, coffee, and ice cream for lunch. We certainly seem to have a fine bunch of officers now. They change them continually, though. The camp at Remote is under Navy and Marine Officers.

I see by the paper the U.P. [Union Pacific Railroad] is to reduce the coach fairs to 2\&. This will be a lot cheaper traveling. I saw an advertisement in the paper of the S.P. [Southern Pacific Railroad] $\$ 50.50$ rate to Chicago from Seattle via Portland, San Francisco, Los Angeles, El Paso, and K.C. [Kansas City]. This isssurely cheap. I believe this can't help but bring them trade. The Catherwood case is sure good to read. I'T1 bet a lot of Fremonters attended the trial.

I just received a letter from you now. I suppose that before I receive one here my address will be changed again. I feel fine now. What pictures did Heeses want to see? Maybe they were the phoney ones. You sure don't have much luck hunting. It's funny how some people like to hunt coon early. 
If possible I am going to get a listopf the things accomplished at Drew this year for a news item in the Tribune.

With Love,

Norman

60/ The "Catherwood Case" drew headlines in the Fremont Tribune for a number of days. Theodore Peterson, a railroad engineer, brought a $\$ 20,000.00$ suit against William Catherwood al leging that Catherwood had alienated the affections of Peterson's wife. Spectators filled the courtroom each day of the trial. Peterson won the verdict in the amount of \$7,500.00.

61/ I do not recall ever obtaining a list of the accomplishments of CCC Company 754 in 1933.

Anchor, Oregon

October 22, 1933

Dear Folks -

Well, I am still at the Cow Creek [Devil's Flat CCC] Camp. They say that we will move the day after tomorrow to Remote and if we do I will have a card mailed immediately with the new address. I believe that the papers from Fremont will stop soon as I am one of the few still left here.

I received Emerson's letter yesterday and it was fine. The duck hunting seems to be poor this year. Didn't Geo. the F.F.G. [Fur, Fish, Game] to the new address which I will send soon. They are having the basebal1 magazine sent to the library so I can get to read it regularly. This camp is in a good place as the sun gets to shine into it every day. I'll bet there is a lot of banging going on in Nebraska now since the pheasant season opened. I see that they are going to have pheasant feeds in Fremont now.

Last Friday I helped mix concrete for the drying room floor. The sand they use out here is sure coarse. 63 I washed my clothes in the evening so I could go hunting Saturday. Art Joens 63 of Scribner completely wrecked one of the dump trucks Friday noon when he collided with a Dodge sedan. Only a child in the sedan was hurt al though the truck rolled over 3 times.

I got up early yesterday morning and went to the hunter's camp up the road a quarter of a mile. We drove up to the Devil's Flat G.S. and hiked up the trail 64 miles to Red Mountain. I had a 32-20 borrowed from a local and

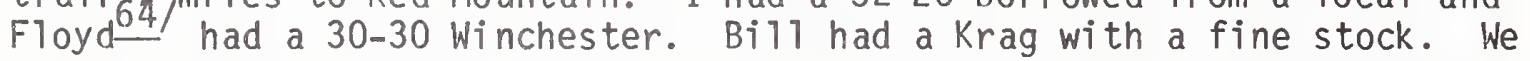
strung out and started a drive down a divide. In about 200 yards Floyd shot once and yelled he got a buck. It was jumped about 100 yards above me. We ran up there stuck it, gutted it, and hung it up. It was rather small but still a darn good one. We hunted till we had to hit the trail for home and just jumped one more big buck. We just got to the car by dark and had to eat supper with them. We fried some of the venison and it was sure good. The hunters came from Salem, Oregon. 
I went fishing this morning but it was no good. I believe it is too cold now. There should be big fish in Cow Creek. There are a lot of the kids in the camp at Roseburg to a movie. They take them to a movie every Sunday now and a dance every Saturday evening. The camp is coming up slowly. There are bunks in the bunkhouse so we can move in if we wish.

With Love,

Norman

62/ The identity of this George is not recalled.

63/ Arthur E. Joens was a member of the original CCC group leaving from Dodge County, Nebraska.

64/ The last names of Floyd and Bill are not known.

Oregon

October 26, 1933

Dear Folks -

Wel1 I moved over to Camp Remote last Monday. The camp over here is surely fine compared with Camp Drew. We eat out of plates here and have good silverware to eat with. The food served here seems to be quite a bit better than at Drew. I believe that you can find Camas Valiey on the map I sent you. It is 24 miles from Roseburg on the highway between Dillard and Coquille.. The camp is in charge of Marine officers who seem to be good. The camp is within a mile of the paved highway.

The mountains seem rather low here and are very gradual compared with those at Fawn Camp. This is the coastal range here. The timber here is entirely different from that at our old camp. It is fine timber although mostly smal1. This is state forest property here. There seems to be very few deer here. A man was killed at Drew yesterday and they just jailed the other man. It sounds like the hillbililes that live there. We moved into the barracks last Tuesday. They are sure fine compared with the tent with dirt floors. The floor has tar paper on it and the outside of the building is also covered with it. I have a lower berth and like it fine. The partner above me is Nicholas Laudenklas. He snores something awful but he don't get drunk much so I won't be vomited on. The bunks are rather hard (1" by $6^{\prime \prime}$ for springs) but sieep we11. They have two stoves in each barracks. There can be 52 men sleep in each one. I have put in a lot of nails to hang the stuff I have.

The mess hall here seems very quaint. It is covered with shakes all over and the timbers are all of log. The tables have oil cloth over them which makes them seem more like home. They are going to build us a new one and put some good flooring in so they can hold dances. There is a piano in there and a worthless radio. The canteen is also in here. They are going to make this their recreation room later on. They give us fresh milk every morning here while we hadn't had it for over a month at Drew. Also butter every meal. They serve cake every supper. 
The building is not coming along as fast here as at Cow Creek Camp. There is not a single building completely up here. The carpenters work a lot slower than the CCC's although they get $\$ .72 \frac{1}{2}$ an hour. There is little or no freezing weather here so the pipes for the water system hardly have to be buried. They say it rains very hard here though.

I am working with an idiot stick $\underline{65 /}$ now sloping banks along the roadside. The road project here is from Camas Valley to Peck which is south of here. They are going to make a side camp at Peck and work this way. I wonder if we have to work if it rains too hard.

We must not be over 30 miles airline from the sea here. It is foggy every morning but I feel fine anyway. I suppose that you got my card but I don't expect to get another letter for a week. I received the magazines yesterday and they sure were appreciated. When you get a few more you can send them.

Well this is all the news so I will quit.

With Love,

Norman

65/ The common name we used for a mattock was "Idiot Stick." The mattocks were used to either chop or grub. 
Dear Folks -

I don't have much to write about except that it's raining al1 the time. There is an awful lot of mud too. I worked slashing timber on the new roadway Friday. We got nearly 8 miles up the mountains and it is a very pretty country. It has been foggy every day I have been here so I haven't seen very much of the country. I suppose that we will have to work in the rain as we had to last Friday. I will get tomorrow off in the morning for helping unload a load of 1 umber. They get the lumber from Coquille.

Wel1, I sure have a lot of time to rest up now. No fishing. They have a checker board here and I play quite a lot. They also take the Coos Bay Times (Marshfield) and it is sure good reading. A typical sea paper. I haven't received a Tribune or a letter from you for over a week but will get them the last of this week I believe. A couple of the men are still at Cow Creek, but I think they will come over soon. The CCC trucks had another collision last week. They drive too fast.

One of the old crew left for home last week. I will stick it out if I can stand the soakings. It rains hard here not a drizzle. The natives stick their heads out of the barracks and say, "I see the coast fog is blowing in." The work on the camp is very slow when it rains. I don't see how they can build roads when it rains and the gumbo is awful here. I kind of hope we can't work and they move us.

They issued us our winter clothes yesterday. They were a pair of overalls, four pair medium socks, one lumber jacket, one 0.D. shirt, one pair four buckle overshoes and a good work cap. We got a good comforter several days ago. It sure is a lot warmer sleeping than the old Army blankets.

It looks like Ford [Motor Company] and General Johnson are going to have a big argument. I believe Ford might call the NRA's [National Recover Act] bluff and win. It looks like his bid on the Government trucks is better than GMC's. The farmers are sure raising the devil.

Well there is no news so I will close.

Your soldier,

Norman

I see Uncle Frank won his case. 
Camas Valley, OR

November 2, 1933

Dear Folks -

We11 I received two letters yesterday and also a lot of Tribunes. They were brought over from Devil's Flat except the one letter and last Tribune. I feel fine now. It is raining all of the time now or rather the coast fog is blowing in as a true Oregonian says. I put on my raincoat, fatigue hat, leggings, and double jackets and keep fairly dry. They may give us a real rainsuit they say.

They paid us our wages last Tuesday night and soon some high class crap games had busted many. I got $\$ 11$ again but am going to save it for a long trip. They will give us all a 7 day leave so I can go somewhere. They are going to take about 60 to Portland next Saturday (Noyember 11) to see the footbal1 game and the city. I think I may go to Friscou if I can later.

I am sending you several pictures. One of the Umpqua River. The other is of a big deer which is about 10 times as big as the one I helped pack in of the best stories comes from the elk country in northeastern Oregon. A city man rented a burro to pack in his equipment a long ways on the trail. He unpacked the burro and turned it loose to pasture while be stalked the bull elk. He hunted and hunted but did not have any luck till he finally sighted one. He shot it and found it was his burro and he had killed it. He had to pack it all out on his back.

I am helping put in culverts now and it isn't such bad work. I would like to get a crack at falling timber though. I don't believe that the bosses know this business as they did at Drew. They don't get near as much out of their men and ride them more.

I sure think you had good luck hunting pheasants. I would like to hunt grouse out here but I think I will get a chance sometime. I have sure read a lot in the F.F.G. [Fur-Fish-Game] and have three issues to read yet. I see that they are to enlist many more men soon in Nebraska. I will tell you when I want more F.F.G.'s. Does Emerson have much chance of getting ahead in Cranes? I sure think the new Win[chester] Model 12, 410 [gauge shotgun] is a good small gun.

What do you think of the farm situation now? I am sure glad we are off of the old place. Well this is all so I will close.

Lovingly,

Norman Myers.

66/ My apologies to the Mayor and residents of San Francisco, California.

67) The picture was of an exceptionally large deer killed near Burns, Oregon by Louis Lange weighing about 350 pounds. It was carried in the local newspapers in Oregon. 
Camas Valley, OR

November 5, 1933

Dear Folks -

I received your last letter Friday with the criterions too. I have read the criterions and enjoyed them. I have read everything in several of the

Fur-Fish-Game and will be through them in a couple of weeks. When you get the next three issues of the magazine you can send them out.

Today was sure fine weather. This afternoon I took the Kodak [camera] and shot out the remainder of the roll of film. I took a picture of some logs sawed out of the big sugar pine they cut down. It was 219 yegrs old and I figured it had between 6,000 and 9,000 board feet of timber in it $\frac{68}{\text { s }}$.

The next picture was of an old mess hal1. Two of the valley scenes and one of myself. I walked to the Coquille River this p.m. The timber in the bottoms is nearly all old oaks. The leaves are falling and they are very pretty. The/ river at this point is a 1ittle larger than Pebble Creek west of ScribnerI don't think the fishing would be very good now as the water is black from the oak leaves in it.

I met a couple kids down there and went hunting pigeons with them. I shot at one flying and missed but they got two apiece. I had a fine day with them. They said that they would show me a cougar hide so I went to a cabin with them. They had a fine half mounted cougar, four bear rugs, three coyotes, three bobcats, a couple steel [silver] gray squirrels, and many other things. This man has a young hound and hunts cougar and coon with it. The pigeons we shot I have never seen before. They are like the gray barn pigeons in Nebraska but these live in trees wholly.

I didn't spend much of my money yet and hope I get to go to Portland. All of the men went to Roseburg lately but I didn't have anything to get so didn't go. A11 I needed was a mirror and I got it here. I forgot to tell you I didn't see a coon, mink, or muskrat track in all of my travels today. I like to wander around in the timber better than to go to town. Last Friday I saw a buck within 100 yards of camp when I was going to work in the morning. I am still helping put in culverts and cleaning ditches.

I have surely seen a lot of news in the Tribune lately. The men that were transferred to Kansas sure hate it they say in their letters.

I hope this find you all well. If you happen to locate a job, have the employer write to me as they don't let one out on the parents' request now. The boost in the ad sounds good for Emerson. Well I am about out of news. I capnot understand why the banker did what he apparently did with dad's money

With love,

Norman Myers

68/ Upon arriving at the Camp Remote site, all trees had been cleared from the area except for one huge sugar pine. It seemed to me these sugar pines were the most beautiful trees in the area. This pine was soon cut.

69/ Scribner is a small town located about 20 miles northwest of Fremont, Nebraska. 
70/ During 1932 Dad borrowed about $\$ 1,500.00$ through a local bank by using a Federally funded program. Upon having the farm sale during February 1933, this banker took all funds that evening for depositing in his institution with, according to Father, instructions this loan was to be paid. However, about November 1, 1933, dad received a letter from the U.S. Attorney advising he was charged with selling mortgaged property and keeping the proceeds. Since the bank through which this loan was obtained while keeping all proceeds from the sale, went bankrupt, it was difficult to justify the Government's position. I never heard anything more about this problem after dad received the letter.

Camas Valley, Oregon November 9, 1933

Dear Folks -

I received the letter of November 3 today and also the Criterion and Tribunes October 28-30 and November 4. This is sure funny as I got the November 1 and missed the 2nd and 3rd. Emerson has sure had good luck hunting coon. Is the season open officially now? Has it been changed to November 1 ? I see that Lester Thomsen has been arrested 11 . It looks like they will really sock him. I hope I get the pictures of the coon soon.

Well I moved into a side camp at Buck Mountain last Tuesday. The road was not completed clear into the camp so the cat had to pull the stuff in on a sled. This camp is about 8 miles southeast of the main camp at Camas Valley. We have to live in tents here but it is so warm it doesn't seem at all bad. We are building the new road into the mountains toward Peck. As soon as it rains hard we will have to leave they say. We have a small shack made out of shakes to eat in and they say we will have plenty of venison too. I am going to shoot a buck as soon as I can if I am able to. They expect the side camps to eat deer as it is nearly impossible to pack in fresh meat. There are only 16 men in this camp including the cook. This is surely a pretty country up here such fine timber.

The weather is as fine as I have ever seen here now. Every day would be perfect to play basebal1. It is warm at night and just the right heat in the afternoon.

I sure feel fine now too. I have had a little cold but it has about all left.

They say that they will probably take three trucks to Portland Saturday to see the town and the football game. I am going if I can and I have plenty of money. It would sure be a fine trip. Oregon University [University of Oregon] and Oregon State sure have fine teams.

Yesterday we got the [bu11]dozer stuck in a mudhole. It took all of us all day to dig it out. It sunk in a spring hole and went in a good 4 feet. We put in four culverts today. I think I may get a job bucking or slashing timber when we settle down to steady work. Wel1, I don't have much more to write so will close.

Lovingly, 
71/ A Lester Thomsen was arrested for having three coon and two oppossum hides in his possession on 0ctober 31,1933 . He was immediately released from custody for 30 days in order to conplete his work as a cornhusker. Final outcome of this case is not known.

Camas Valley, Oregon November 12,1933

Dear Folks -

We11 it is Sunday again and I am going to write this morning as I may have to go up to Buck Mountain this p.m. It is foggy every day down here but it is clear up at Buck Mountain and much warmer. I have a slight cold and sore throat now I suppose from eating too much candy. I think I will go out walking if I don't go to the side camp this p.m.

I am sending several glippings taken from the Coos Bay Times that I thought would be interesting . They had an airplane wreck up near Portland again and I suppose you may read about it. This is the second plane crash this line has had on this division since I came out here, Portland - Medford. They haven't found the plane lost in June yet. I see in the papers that Uncle Frank made a foolish mistake again. The World Herald sure razzed him in their article.

I worked digging the toilet hole up at our camp Friday. I came down and thought I might go to Portland but they called the trip off. I sure would have liked to have gone. It looks like Nebraska may be the Rose Bowl choice this year.

They had a big feed yesterday as Armistice Day [now Veteran's Day] is a big day for the Army. We had baked chicken and ice cream. They had a big celebration in Roseburg. A big parade, a football game and stands. Most of the camp went and I guess the celebration was a success. A lot of the men are in [Roseburg] again today.

We11, I am out of news so will close.

Lovingly, Norman

Emerson sure had luck hunting coon.

72/ These three clippings related to the Coos Bay Daily Tide Table, the Nelson and McCormick Lines Coastwise Services, and the Shipping News Tisting ship arrivals and departures from that port. 
Camas Valley, Ore. November 16,1933

Dear Folks -

We11 it is the sixteenth of November now and it was just six months ago today that I left Fremont. It surely has gone quickly and I suppose that the rest of the time will go fast too. Last Sunday p.m. I went down to the Coquille [River] and monkeyed around quite a while. I saw a good size trout strike and then in a short time strike again. Going into a field I picked up a number of grasshoppers and threw them into the stream one by one. The trout layed under a big $10 \mathrm{~g}$ and every time he saw a grasshopper would sure splash when he struck. It is a lot of fun just to watch the fish and birds and not trying to get them.

Sunday night they had my name on the K.P. list and I had to talk pretty fast to get out of it. That is one blessing of being at a side camp.

They have announced that the men may go home if they are gone less than 5 days for Christmas and New Years. This is an awful short time and it is only intended that those in camps close to home go. I have nearly decided to take a correspondence course in Forestry or Engineering from Oregon University [University of Oregon]. I can get 3 hours credits for $\$ 7-\$ 10$ depending on what I take. It would certainly help pass the time on the long winter evenings.

They say that a barracks building is to be erected at this side camp so that it will be comfortable all winter. That would sure make it nice up here. The barracks down at the main camp are nearly completed. The forestry [Forest Service] and Army have both moved into their respective buildings. They have also put in sidewalks connecting all of the buildings keeping us out of the gumbo.

There has been a new group of rookies, pyt into this camp. They came from western Nebraska and from 0'Neill too- This company has men in it from all over the state now but most are from north of the Platte [River]. There were 49 of the new rookies. They sent some of the men up here to brush yesterday and they were a seedy looking outfit. They are a lot thinner than the outfit that is here so I suppose that the food must be good. Quite a number of the men intend to go home soon they say. One goes tomorrow.

For a couple of days, the first of this week, I did only odd jobs such as putting in culverts and sloping roads. The last couple days I have been working on the powder crew and time surely goes fast. They use DuPont dynamite and it seems better than the other brands. They use Western [blasting] cans made by the [Western] Ammunition Co. They use drills instead of bull pricks too.

I think that I will stay up here this weekend. I will have plenty to read in the magazines. I still have part of the September issue of Fur-Fish-Game to read so you might as well wait and send the October, November and December issues together. 
I received Emerson's letter yesterday and it was sure good. The pictures were fine. He has had good luck hunting lately. The weather must be cold in Nebraska now. It is rather cool here now and I suppose it will rain. Tell Grant I am going to send his letter to Doris and she will find out what a man she has married. I feel fine now.

Yours with affection,

Norman

73/ O'Nei11, Nebraska is a smail city about 150 miles northwest from Fremont. It is located in Holt County, Nebraska.

74/ As I recall a "bull prick" was a rod we drove into the loose rock and soil through use of a sledge hammer. A tool was then used to turn it for easier removal. While at Camp Drew we used the bull prick exclusively except where a rock drill was required.

75/ Doris was the wife of my cousin Grant Lundstrom.

Camas Valley, Oregon November 19,1933

Dear Folks -

I stayed up at this side camp this weekend and saw that no one stole anything. It is raining now and I suppose it will keep it up for a long time. We have certainly had fine weather up till now though. We have 77 inches of rain to get so I suppose that it will start coming steadily soon. There is a lot of snow up this high as I notice that the firs are bent over by the snows of recent winters.

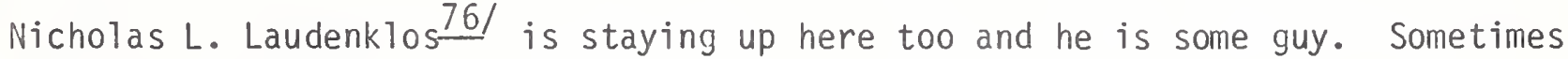
I believe that he is dumb. I hunted deer this morning but didn't have any luck. I just like to go tramping in the woods anyway as it is a lot of fun. I seem to be able to find my way around fairly easily. I didn't even jump a deer and this is rather unusual but I don't know much about hunting yet. I had a Winchester Model 184530 [caliber] U.S. rifle and it is a nice gun. There is an unwritten law in the sticks that a man cannot be deprived of fresh meat so we have our venison rather regular.

I'll have to tell a joke on Nick. His mother wrote Doc. Ludden $\underline{77}$ and wanted to know how he was coming along. They are afraid his morals are degenerating as he wrote home for $\$ 3$. His mother is afraid he is smoking and playing poker which he never did at home. The truth is that he smokes cigars, plays poker and got layed out [very drunk] once from mountain dew . Doc wrote back that he is the model young man around camp.

I helpeg burn brush last Friday with some of the new men. One by the name of Wilson- comes from Harrison [, Nebraska]. He knows Con Parsons, Coffees, Maroviks, and a lot of the men you taught. Virg Hester has served 2 terms in the penitentiary. Con Parsons son is teaching in an eastern university. The kid was surely a good worker. 
A cougar hunter came in here yesterday with three dogs and went up toward Dutchman Butte to hunt. The two hounds struck something and trailed it out of hearing. It sure made him sick as he had just bought them. He figures that they hit a deer trail but he can't figure out where they went.

Saturday I went to Live Oak, a high rock. I saw many snow capped peaks from there and took two snapshots. I noticed that the north slopes of this mountain have much better timber than the south slopes. The sun must cause this. I had the gun along all of the way but didn't see anything.

We11 I am about out of news so will close. I am feeling good now. We move up the road to Live Oak in a couple of weeks.

I haven't received any mail since last Wednosday so haven't had a letter.

Lovingly,

Norman

76/ Nicholas was an enlistee from Dodge, Nebraska. He went under the nickname of "Nick".

77/ Raymond Ludden also was an enlistee from Dodge, Nebraska.

78/ We called the locally made Oregon home brew "Mountain Dew".

79/ John L. Wilson came from Harrison, a small town in the very northwest corner of Nebraska State. My father, George W. Myers, taught school in Harrison for 2 years from the fall of 1900 through the spring of 1902 . It currentiy is believed all of the named families have left that area except for the Coffees.

Camas Valley, Ore. November 23, 1933

Dear Folks -

I have received two letters from Dad and one from Emerson today when they brought the mail up. Also six Tribunes and the Criterion and joke book. A lot of the men read the paper as it is the only one delivered in the camp. There was a lot of news in the last ones. I hope the bank in Scribner opens up but it seems too good to be possible. I believe I will send some money home one of these days to take care of the expenses I am getting there.

We are having some more fine weather now. The rain stopped Monday morning and it has been clear ever since. It is so warm that one is comfortable with[put] any [extra] clothes on. We are working on the road to Live Oak yet and have nearly 2 miles slashed, felled, and blasted. The bulldozer is not here now so we have to walk to and from work and eat lunches out there. We have worked 2 miles in less than 3 weeks which is good time for 14 men. They are awful strict about the amount of powder they use here as they are saving of it. 
I heard the cougar hounds that were lost last Tuesday morning about a mile west of here. I couldn't catch them as I had to work. Someone killed a quill hog (porcupine) and we had some meat for a few days. I took a picture of it. The meat is very red, tough and coarse

Nick L. had a nightmare the other night and he was sure wild. He grabbed a messkit knife and was going to butcher the men in this tent. We couldn't wake him. Does he have epileptic fits?

I received a letter from Russell Heese that was mailed in October and got in on November 22. I suppose he thinks I will never write.

I had to leave Camp Drew right after I wrote about the list of accomplishments that we made possible this summer. I am going to try and get some account of them soon if possible.

Emerson is sure having a lot of luck hunting. Joe and Red sure know their stuff even though they couldn't get many last year. Which dog is working best this year? Is Joe treeing wel1? Is Red slowing up much or getting stiff? Your duck hunting is not so successful though. We are transferred too much to have a footbal1 team. Melrose and Tyee both have good teams. I sure like to hear of the hunts you have so write a lot about them.

$$
\text { Lovingly, }
$$

Norman

80/ If the porcupine meat we ate was a fair sampling, I could never recommend it.

Camas valley, ore. November 26, 1933

Dear Folks:

I haven't received a letter from you since last Thursday, but received three then so didn't expect any. I like the letters Emerson sends especialiy well. The weather here is fine and I suppose it won't break for several more days. This does not seem at all like winter. It seems like spring. It is slowly getting cooler and I suppose it will snow and rain soon.

I didn't go to the main camp again today but I am going in next Thursday if I can to get in on the feed. Friday is pay day again and it is the last day our Drew ratings hold out so I will get only $\$ 5$ after this.

I didn't have much to do this weekend. They made the men check in all of the guns in the camp so I couldn't go hunting. I was thinking of buying a cheap single shot 22 [caliber] to hunt with but I can't do it now. I think these grouse would be fine eating. I went prospecting all day today but I didn't find any gold. They say there is none in this country but I tried anyway. I like to just get out and wander over the hills. There are lots of monstrous sugar pines east of camp that are the size of the one I took the picture of. I may have told you before that they measured the tree and it had over 15,000 [board] feet of lumber in it. 
Well there is no news so I don't know what to write about. We are getting our road clearing done fast. We are supposed to move to Live Oak in several more weeks.

I am feeling fine now and hope you are too. Why doesn't Ruth write? I suppose she is busy. I'll bet Emerson has some more coon. You shouldn't send me anything for Christmas as I have everything I need and some that I don't to take care of.

Lovingly,

Norman

Camas Val ley, Ore. November 30, 1933

Dear Folks:

Well it is Thanksgiving evening and I have loafed all day. We have had a big feed today and the bosses and their families were even here. I am sending you the menu and I want you to keep it. I have been busted from assistant leader to member now so my pay will be $\$ 5.00$ instead of $\$ 11.00$. I figure that I was lucky to get what extra money I did anyway. There were only two men from Camp Drew that kept the raise as the [Camp] Remote men are better known.

We got paid last night and I got the $\$ 11.00$ again. Someone went through one of the barracks and stole $\$ 38.00$. They took $\$ 20.00$ from one man. I am going to send you home some money to pay my bills. They steal everything that is loose here. It is certainly not safe to keep money.

We don't have to work tomorrow and have to make it up next Saturday. They wanted to give the locals a short vacation. A large number of men are going home soon from our barracks. There are seven that I know for sure. The weather is the main factor in the men going home I am sure.

Maybe you remember that I stayed up at Buck Mt. last weekend. We ate up 7 dozen eggs in the 2 days and the Army raised hell about it. Also 4 pounds of butter. I guess we lived too high but they couldn't do anything about it. I told them I had to eat. It snowed about 6 inches last Monday night and we nearly froze to death in the tents. The barracks are much nicer to sleep in. The forest is pretty with the fir bough laden with snow. I was disappointed in the tracks in the snow. The first morning there were none of any kind except a buck I jumped and the second morning only deer tracks. I though there would be cougar, fox, coon, wildcat and marten tracks but I never saw a single one. I believe the Cascades [Range] would be better for fur than here. It snowed very little at camp and is melting fast. It made the working miserable though.

The road clearing is slowing up a bit now but we are still going ahead some yet. The bulldozer is up at the camp now so we will soon get the ride in the trucks to work. Last Sunday the men in camp got in a free-for-all fight and at least one got the worst of it.

The kid's piece on Oregon in the paper was good. ghe said the elevation at their camp 62 miles east of Eugene was 25 feet(?). 11 . I receive the Criterion and the things to send papers home in. I am going to send the Coos Bay Times 
soon as it is a small daily published at Marshfield. It is a good small paper for a town of 4,000 population. I was disappointed in the Portland's paper.

The natives say steelhead fishing is good in the Coquille [River] here so I am going to try it with salmon eggs. I hope I have some luck. I will fish later as the run has hardly started yet.

I looked up the University's course more today and I didn't have near enough money for it. A course complete with books not counting paper costs $\$ 19.00$ with al1 the fees and I couldn't afford that. I can read the forestry books here and learn as much anyway but I will get no credits. I don't need them anyway.

I am sending $\$ 12.00$ in this letter and tell me if you get it. This should cover my expenses, taxes, and paper subscription. It would be useless to take a trip now as it is so foggy one cannot see a block ahead any of the time.

We11 I have no more news so will close.

$$
\text { Lovingly, }
$$

Norman

81/ I questioned the accuracy of the altitude of 25 feet above sea level given in the article for a CCC camp located 62 miles east from Eugene, Oregon.

Camas valley, Ore. December 3, 1933

Dear Folks:

We11, it has rained a11 day yesterday and today. I believe the rainy season has begun in earnest and we will be wet all of the time we work. I was wet a couple days last week and I got used to it. I feel fine now and must be heal thy. Look at my weight card, 174-3/4 pounds. This is with no overcoat just oxfords, shirt, pants, summer underwear, and lumberjacket.

Yesterday I sent several papers the Coos Bay Times, Seattle Times, Roseburg News, Portland Journal and Oregonian. The opinion of farm relief is differently here than back in the middTewest. The Seattle Times I robbed of some sheets and the only important ones are still there. I like the coos Bay Times best as it gives much sea news.

I went to Roseburg Friday and spent a11 of my loose change. I still have $\$ 5.00$ left for Christmas so don't think I am broke. They have been stealing clothes and trading them for 1 iquor some say. I sent you the $\$ 12.00$ so it wouldn't be stolen and I could pay my debts at home. I saw a fine movie and good vaudeville also pipe organ music. The show was "King for a Day." I looked rather longingly at the apple display at the Chamber of Commerce room and the secretary gave me a golden delicious. The people treat the CCC boys fine but some of the $3 C^{\prime} \mathrm{s}$ are unappreciative. Some steal and beg everything and are mouthy. I saw a lot of Christmas presents and the town has beautiful windows. 
Two nice kids left for Nebraska yesterday. OnE, Art Joens [Arthur E. Joens] says he will see Emerson at Cranes Auto Supply . I think 1 will be able to send the article for the paper as I have already requested the information and it will be sent to me soon. The political pot seems as if it will boil over soon. I still know Roosevelt is a good president. They are spending too much money now though. If a man is to receive charity why not make him work for it? I bought a pair of cork loggers [boots] and I will use them hiking back in Nebraska.

The camp is fine now and the barracks are warm. It is much better than a side camp but it seems as if I will have to live in the hills again this week. Maybe you notice I bought some writing paper. I hope it reads easier. Time sure goes fast as my diary is nearly full now. In 4 months I'1l be back.

Emerson has fine luck hunting. Where did he strike the old boe along maple[?]. What did you mean by the question; is "Camas" a berry? We11, I am out of news.

Lovingly,

Norman

82) Arthur E. Joens was from Scribner, Nebraska.

Camas valley, Ore. December 7, 1933

Dear Foiks:

I received both of your good letters Tuesday. I am still up at Buck Mountain and we have been dynamiting every good day this week. They brought an air compressor up the road to about a quarter of a mile below camp to drill rock which lays over a gravel bed. They intend to gravel this road this winter. The air compressor is made by Ingersal1-Rand and is quite a bit different than the one we had this summer. We worked with this Monday. On Tuesday we blasted stumps up near Live Oak. Orie man got hit on the head with a big rock and got knocked out. He got a big cut and they had to shave his head and sew it up. It will make us all be more careful, I am sure.

Yesterday it rained and we cleaned up around gamp. We raked up the widowmakers that fell in the wind the night before ${ }^{8}$. Today was a swell day. We worked up the mountain again and accomplished quite a bit. We have the camp fixed up real nice now and it is fairly dry when it rains.

Is John Swanberg working now $84 /$ ? I received the Fur-Fish-Game November issue today and it was good. I didn't get October's issue. Did you send it? Also read the Criterion, Cornhusker, Clippings and the Post. I read three stories in the Post already. No papers or magazines come to the side camps so I like to read the Tribunes and magazines. Send the December issue of Fur-Fish-Game, if you can, so I can have plenty to do over the holidays.

The pictures were sure good. I keep all of them and you will get them when I return next spring. I doubt if your weather is any better than that we had today. Can work naked if we wanted to. I like to hear how the hunts turn out. 
Well, I am about out of news so will close. I am well and getting fatter every day.

Lovingly,

Norman Myers

83/ Widow-makers are 1 imbs that fall from tall trees. High winds seem to make the tops of tall trees brush against each other resulting in sizeable limbs breaking off from the main stem and falling. These falling limbs are dangerous.

84/ John Swanberg was a distant cous in who Tived in Fremont.

Camas Val ley, Ore. December 10, 1933

Dear Folks:

We11 it is December 10 and as I recollect about the time the foggy spell comes in Nebraska and also the good hunting. Emerson had ought to get 15 coon this year which is good. Even 12 is darn good. How many had Fritz Arps caught $\frac{85}{\text { ? }}$ ? Two weeks from tomorrow is Christmas Day and we will have a big feed.

I stayed up at this camp over the weekend. I like it when it is quiet and I believe I will stay here most Saturday and Sunday, going in for the Christmas weekend. I hope we don't have to come out that week to work. I bought some Christmas cards and I am going to send them the last of next week. The weather is so nice now it hardly seems possible that the holidays are here. I will send you some more papers the next time I get a chance. I suppose you got the ones I sent before but I may have not had enough postage on them.

I worked last Friday on the road down Chipmunk divide. We reached the end of the road as far as surveying is completed and now start up the road to Live Oak lookout. We have 4,100 feet of it to build and then we continue the main road toward Peck. We are going to move to Horse Prairie within several more weeks.

I received your letter yesterday but didn't see anything of the corn lists in the paper. I missed Friday's issue so I suppose it was ing it. The papers here propose that the new train runs from Portland to Seattle ${ }^{86}$. The Roosevelt administration is a least helping the farmer actually more than the Rep[ublicans] did. It is the consensus of opinion of the common people here that the in California was the best thing that could have happened to the state $8 \%$. I think some of it is fine (the editor would think so if his children were kidnapped). If people are to receive charity, why not have them work for the money? There is no drinking done by about 9/10 of the CCC's and the 1/10 give them the name.

I don't have much to write about but I suppose you like to hear from me. I am feeling fine.

With Love, Norman

85/ Fritz Arps was another coon hunter in the Fremont Area. 
86/ The Union Pacific Railroad was bringing out a new streamlined, light weight train said to be capable of operating at 110 miles an hour.

87/ Two men described as "kidnap-slayers" were lynched at San Jose, California. Due to the stand taken by Governor James Rolph of California about the matter, a number of organizations demanded the resignation of the governor.

Camas Valley, Ore. December 14, 1933

\section{Dear Folks:}

Well I have as little news this time as I have ever had. It has rained the last 4 days and I suppose it will rain till the last of March. It started to snow tonight and the snow is several inches deep now. The snow has been coming down lower on the mountains every day lately and now it is below us.

Last Monday I had to go down to the main camp in the evening and sign the payrol1. They are going to pay us on December 22 so all of the men will have money for Christmas. I will have plenty of money if I want to go to town even if all I get is $\$ 5.00$. I think I will not go into the camp this weekend and wait till Christmas.

The working this week has been miserable as we are wet from head to foot. They didn't issue us our rain clothes as they told us they would. We have worked on rock all of this week. The rock here is sandstone and shale which is rather soft. They say that we may move to Peck in January which is on the SP [Southern Pacific Railroad] so won't be so lonesome. If we go there we have to go by train as no road is in there yet. There is gold there so we can make a rittle [money] panning.

I am mailing my Christmas cards tomorrow as it will be toos late next Monday, I am sending you a clipping of the big fire here last summer 28 . I received the package today and am enjoying the contents. I saw a lot of news in the paper in the last few days. Well Art Joens got home and I'11 bet he was happy. I read "Tom Sawyer" this week.

I received mother's Ietter Monday. Also one from Donald Sic lately. What will dad do about the hay ? Emerson had hard luck with his coons but he has done swell so far. Is Grant goofy or what ails him? I wouldn't quit a job now.

Wel1 I will close now.

Lovingly, Norman

88/ This clipping related to the Tillamook fire which burned during the summer of 1933 .

89/ This hay reference was about several tons sold at our farm sale that the successful bidder neither paid for nor removed. The renter who succeeded us on the farm then fed it to his livestock. Therefore, dad apparently received nothing for it. 
Camas Valley, Ore.

December 17, 1933

Dear Folks:

It is Sunday evening now and I am sitting in the tent listening to it rain. It has been storming for the last week. It snowed hard Thursday night and Friday and it was a foot deep here. Then it turned off raining about midnight last night and cleared the trees and ground of snow. I took several pictures of the snow yesterday and hope that they turn out good.

One of the tents got logged with slushy snow and forced the pole into the ground about a foot. The water leaked through the wall at the rug and wet a few beds. This afternoon a widow-maker crashed into our tent and only missed a kid's head by a couple of feet. It was a pitchy limb so we chopped it up and burned it. It made a bad hole in the roof though.

We had to clean up the cook's tent tonight and I noticed the rats had gnawed a roll of toilet paper up and then saw a nest back of the stove. They picked a warm spot for their nest. The rice bags have been gnawed into and were covered with small turds. I won't eat rice for a while I am afraid. I just heard another crash which is a tree falling. I have heard three fall today so the wet season must be here for good.

I have had a cold lately and suppose it will stay for a while as I get wet every day. It sure rains steadily here but there is almost no wind. I am going to get some medicine when I go to the main camp. The bulldozer got stuck Friday and we worked all day to get it up the mountain again. It weighs 11 tons so it slips down rather easily. It has to have a solid bed for its traction.

I am going to go the the main camp for Christmas and New Years. We will get both days off. I suppose this will arrive about on Christmas. I enjoyed the crackers and candy you sent. I haven't received any mail since last Wednesday so will have a lot tomorrow. Hoping you have a Merry Christmas, wi th Love,

Norman

Camas Valley, Ore December 20, 1933

Dear Folks:

Maybe you think I am dizzy, but I want a little money. I am going to take a trip on the New Years furlough. The S.P. [Southern Pacific Railroad] has made special rates to the CCC's. The RT [round trip] rates are $\$ 4.00$ to Portland, $\$ 7.65$ Seattle, and $\$ 11.00$ to San Francisco. I have $\$ 7.50$ of my own money but need some to live on while gone. We can be gone 5 days. Send Travelers Cheques or it some way so it isn't lost.

I am in the hospital now as my cold kept getting worse and got me down. I will be out in a few days. I can't write much as my position is bad. I got candy, mag's, and two letters lately but can't eat candy now. 
If you send money, send by air mail.

Camas Valley, OR

December 22, 1933

Dear Folks:

I am going to start a letter tonight and finish to tomorrow morning. I have a number of letters of yours to answer soon. I really haven't written you a decent letter since last Sunday. Last Monday I worked up on the mountain blasting rock and then I had a fairly bad cold. Tuesday I was sick so I came down to the main camp in the evening. We were issued another four pair of socks and a vest to wear. This makes 14 pair of issued socks that I have now. They also issued us our rain clothes which are fine. They are Towers "Fish" brand and are a pair of rubber coated overalls, jacket, and hat. I believe my cold came as a result of my getting wet every day last week.

When I came down here they put me into the hospital and I just got out this morning. The beds are nice and soft here and I sure slept we11. The first night I vomited on the floor so it was a mess to clean up. I get well fast though. They know how to cure a cold up in quick order. They use nose drops and iodine in the nose, castor oil, CC pills and quinine.

As soon as the men left for the mess hall the other two patients and I would get up and chase each other over the beds. They have an indoor toilet and running water in the building so we never have to leave the place. The ghristmas leave started today and as one of the attendants left I am here working 90 . It is sure easy compared with road work.

I feel fine now and am enjoying the candy right along. I aiso received the diary and it is fine. I didn't have much time left so I sent the request for money by air mail. I have to have it by next Thursday night if it is to do me any good. We will not be paid till after the holiday so I won't have much except what you send me as I have a little loaned out. I received a letter from Art Joens the other day.

We have had nearty constant rain and snow for the last 2 weeks. There has been heavy damage done in Marshfield, Port Orford, and Gold Beach by the storm. I wish I could see the ocean during a storm. I'll bet it would be a sight. I am enclosing a comical clipping I clipped in the Oregonian. I also will send Leroy [BTack] his card soon.

I forgot to mention that I received the cappers and the sporting magazine. I read all of the Cappers while I lay in bed. I have received at least five letters from home that I have to answer now. Two from Ruth, one from Emerson, and two from Dad. Grant was foolish to gyit that kind of a job anyway right in the middle of the winter. Your program 1 is tonight and you picked a warm one (in Ore.). Grandpa may yet live to see his 60 th anniversary. Those thin crackers are sure good.

Emerson was lucky to get the car back as cheaply as he did. It was best to keep the presents there as I don't neeg,them here. The only thing I miss this winter is coon hunting. The athletics 2 are going to the cellar the way they sell the players. You are as right as to who Art Joens is. Coyote hunting 
must not be as hot this year. Talking about steelhead, I don't know what they are. I never could tell one fish from another. I received the air mail letter Friday noon so it took 2 days to come out.

I hope you have a happy and prosperous New Year.

Lovingly, Norman

90/ The first night after becoming a hospital attendant one of the members of our company came in about 2:00 a.m., drunk, and demanded a prophylaxis. I know nothing about this phase of the work and had to call the doctor for help. To my surprise the Company Doctor was not disturbed about being called from his bed. He cheerfully performed his duties.

91/ This program was given by my sister, Ruth, a school teacher. A midwest custom is for the country schools to have programs given by students just prior to Christmas Eve.

92/ This reference is to the Philadelphia Athletics, then a baseball team in the American League. The Athletics won the league championships in 1929, 1930 and 1931; were secong in 1932; and third in 1933 under Manager Connie Mack. After selling their star players, this team did not win another pennant until they moved to Kansas City, Missouri in 1955.

Camas Valley, Ore. December 25, 1933

Dear Folks:

It was so warm and nice today that it hardly seemed possible that it was Christmas. It has been nice the last few days with no snow or rain. The newspapers are full of the big storm and floods that are menacing Washington now. The railroad lines are out north of Portland but they may have them in by the time I get there. They only run one train a day to Seattle because of the washouts.

I expect to leave for someplace Thursday night if I ge the money by then. I will not get my pay by the time I leave it looks. I will be a little short but I probably will have enough. They said that they would pay the 22 nd of December but now they say it will be the 3rd of January.

We had another fine feed today. I am sending you one of the menus they had at each plate. I received a card from Morgan, a card and letter from Aunt Hannah, and a letter from Cecil today. Cecil is going to move to the coast country as soon as he can get an opening here. He says he will see me for sure when he comes through this time. He ${ }_{3}$ must be tired of Nebraska. What happended to the 0.P. Skagg's store at Omaha 23 ? It seems as if they went broke.

I am still sleeping in the hospital yet and am going to stay here till tomorrow night. I hope I won't have to go up on the hill tomorrow or any this week. I see that they are going to have CCC's run another year but I think I will quit at the end of this stretch and fish in the pits next summer. 
The other morning I was woke up by something biting my ear and half of my face was wet. The dog "Babe," a doberman pinscher is owned by the doctor and is intelligent. He had been licking my face and biting my ear. It is sure fun to have a dog around.

I remember the time we chased the coyote over the Cuming creek and the big black dog was with it. I believe that that was a wolf by the way wolf tracks look here. I have seen a number of their tracks here and they are about the same size as that one's. Did you ever hunt on Dead Timber 94 this year?

They delivered the mail here today and there was sure a lot of it. The packages are mostly wrecked before they get here. They must pile them too deep.

Well I will close wishing you a happy and pinosperous new year.

Lovingly,

Noman

93/ 0.P. Skaggs was the name of a chain of grocery stores in the middlewest during the $1930^{\prime} \mathrm{s}$.

94/ Dead Timber Lake was one of our favority coon hunting areas. Currently it is a Nebraska State Recreation Area. It is located north from Scribner on the east side of the Elkhorn River.

Camas valley, Ore. December 29, 1933

Dear Folks:

It is Friday morning and I am getting ready to go to San Francisco at 2:20 this p.m. I received the money you telegraphed Wednesday morning and I will have a good time with it I am sure. It is dizzy that the air mail letter came to you on Tuesday. I mailed it about 8 o'clock Wednesday morning. The mail service must be unable to handle the rush. I have received letters from Morgan, Cecil, Russe 11 Heese, and Aunt Hannah that I will have to answer.

I am feeling fine now and have had to work up on the mountain the last few days. I had to stay in the hospital till Wednesday a.m. and then moved up to the side camp. Yesterday p.m. I worked on the telephone gang climbing the trees putting a new line along the road. I like this work fairly well but it would be tough if one fell. I came down to the main camp and went into Roseburg last night. Saw a good show and a Mickey Mouse and Laurel and Hardy comedy. I couldn't leave till this p.m. so I came back to camp.

I was going to Seattle but the agent says the transportation is at a standstill north of Portland. Some kids came back last night and it took them 36 hours to make the journey and they had to walk a lot. I can spend 3 days in Frisco and it will be wamer. 
We11 I am out of news so will close.

Lovingly,

Norman

San Francisco, CA

December 30, 1933

Dear Folks:

We11 I thought I would let you know that I am in Frisco. I arrived in 0akland at 10 o'clock this morning and crossed the bay on the ferry. The Sacramento valley was badly flooded and highway closed.

I have seen two movies "Dr. Bull" "Ed Wynn." I took a sight seeing trip this p.m. and saw the Golden Gate, lots of parks and the city in general. They have three street car systems here. One has a third rail. I saw the new federal island prison [Alcatraz]. In one place up the shore, I saw a number of seals. I saw the largest aquarium I have ever seen. It would take a day to see it well.

I am not going to see Howard $95 /$ the way it looks as I don't have his address I have seen several large passenger ships already. I am having a swell time $26 /$. About midnight so will close.

Lovingly,

Noman

95/ Howard Myers was my cous in who lived south from San Francisco.

96/ The stay in San Francisco, California was at the Hotel Argonaut, with 400 rooms. Cost for the European Plan was $\$ 1.00$ a day and up.

San Francisco, CA January I, 1934

Dear Folks:

I am in the Chamber of Commerce Building now. I am going to the game this p.m. Had a good time last night and city was wild. I did not look any of the relatives up as I didn't know addresses. I had just enough money to have a good time on and be respectable. Saw water front yesterday. Also fishermen. Have seen about 12 good shows and one poor one. I leave for Roseburg at 7:20 p.m. and will start [illegible].

Lovingly,

Norman 
Camas Val ley, Ore. January 4, 1934

Dear Folks:

I have received a number of letters since I have written you last. I left last Friday afternoon for San Francisco and arrived there at 10 in the morning. I crossed on the ferry to the city and soon got to seeing the sights. I didn't know Howard's address so I didn't look him up. They are building two new bridges here. One is across the Golden Gate and one is from San Francisco to Oakland. There is a good model of the Golden Gate bridge at the terminal which has been carried away in pieces by souvenir hunters. I had dinner and looked at the window exhibits on the sides of Market Street.

For 3 hours in the afternoon, I was on a Gray Line tour of the city. First I saw the Delores Mission which is very old and interesting. It costed a dime to go through it. I am sending a folder on it back with the letter. I saw the public block of buildings and they are certainly fine. They took us over Twin Peaks which is 1,000 feet high and has a street car line beneath it. The car fare is only $5 \phi$ there and I used it several times. They have three street car systems the municipal, the market street, and the cable line. The cable lines are sure unique. The main drag Market Street has four car tracks on it.

Getting back to the tour they took us to the Golden Gate park next. It is a monstrous park with the Kezar Stadium in it. They have a zoo and an immense [Steinhart] aquarium. It would take a day to look at all of it. They have seals, walrus, and sharks in it. I saw a large exhibit of Japanese fish. They have nearly all of fresh and salt water fish. I knew less about trout since I saw them and their names. They have a big beach with a midway adjoining it. Two immense Dutch windmills pump water for the park. Many seals were on the rocks off the coast. The sea was very heavy and just sprays around the rocks.

Then we went through the Presidio military reserve. This is the largest fort in the U.S. I believe. The large disappearing guns protecting the Golden Gate are located here. There is also the ruins of the old Spanish Fort which guarded it centuries ago. One can see the new federal island prison [Alcatraz] from here. Out quite a ways is the light house and on the opposite side the piling for the new [Golden Gate] bridge. The soldiers continually scan the ocean with field glasses. Here the Lincoln Highway's official end with a flag pole is. one thing I noticed is that the trees and vegetation is mostly tropical and different than that around here. The rest of Saturday I spent in the movies. I stayed in a fair hotel. Sure slept wel1. I saw a number of good shows and one rotten one.

Sunday I went to the waterfront and saw a number of large ships. There were a number of men fishing smelt along the piers and making good catches. The largest [passenger ocean] liner I saw was the "Malolo," a Japanese ship. I saw two large freighters, the "Texas" and "Nebraskan." I saw the old fishermen unloading their catch of halibut, yellow carp, and other fish. The crabs are dipped into boiling water to kill them. The city has many crab stands and no hamburger joints. I went to Chinatown that day too. The buildings are quaint and the windows are sure filled with worthless trinkets. I didn't buy anything although I saw a couple of dice I would have liked to have had. I never went into the cellars, so didn't get into the tough element. 
I went to the movies all the rest of the day. I saw "Dr. Bull," "Roman Scandals," "The Fire Chief," "Riding Down to Rio," and many others. All of the main theaters are fine and there is good vaudeville. The town all comes down on Market Street and goes crazy on New Year's Eve. They celebrate more here than in any town I have ever seen. It rained nearly all the time I was there and I had to buy a trench coat. The Sacramento valley was badly flooded when I went down.

On New Year's Day I went to the East-West football game. The pageant lasted an hour and was fine. The drum majors knew their stuff. During the halves, tumblers entertained the crowd. Sauer played a great game and took the East off of their feet in the first few minutes of play . The East show signs of great speed at times but they couldn't budge the line when they were about to score. At the close of the game the announcer said that a local paper chose the All-American player from the game and he asked who they wanted. They yelled Sauer so they must have liked him. I am sending you the booklet on the game and some clippings.

That night I started back for Roseburg and in the morning woke up up the base of Mt. Shasta. It was clear and I got a wonderful view of it. A range of snow caps extends north from it. I saw [Mt.] Lassen with its misty peak too. On the Siskiyou divide they had two big engines on the train. The tunnel at the highest point must be several miles long. We traveled through many tunnels and much snow. The mountains here are real pretty. The road below Glendale down Cow Creek canyon is the crookedest I believe there can be. I arrived at Camp by chow time that evening.

I still have $\$ 4.00$ so I had plenty of money. I 1 ived decently even though it costed more. I moved up to Buck Springs [side camp] Wednesday. We worked up on Live Oak today and blasted a lot of stumps. They moved a gas shovel up to the gravel pit below camp and are to load all the trucks with it. I heard the air mail didn't operate during the storm so it didn't help to send letters on them. The common mail is fast enough anyway.

It was too bad Russel1 $198 /$ had to have such bad 1uck. I am going to write him tomorrow. I believe I had as good a time over the holidays as anyone could have had.

I received the letters Dad and Emerson wrote on Christmas day. Dad's letter the day after Christmas and Thursday's letter. Camas Valley is a country store on the highway and has no population, RR or telegraph office. Well this is all the news so will close.

Lovingly,

Norman

97/ George Sauer, of the University of Nebraska, was the star player for the West in its 12 to 0 win over the East's team. This game was the annual Shriner's Intersectional Football Classic.

98/ This referred to Russell Heese. 
Camas Valley, Ore. January 7, 1934

Dear Folks:

The weather the last 3 days has been swell and I suppose that the stoms have passed for the time being. We must have experienced one of the worst storms that this country has had for a long time but the absence of wind makes it not seem so bad. It has been perfectly clear the last 3 days and very warm. So warm one felt like sleeping and not working.

I am up here in the side camp again this weekend. We get better food up here than at the main camp. I lost 7 pounds when I was on my trip but will probably put more on now. They held a dance in the main camp Friday night but I didn't go in to it. They are issuing the knee breeches and leather boots now and they look good on the kids. I have not receive mine yet but will soon I suppose.

Last Friday I worked around camp and blasted a big pine stump just below camp. It was 205 years $01 d$. I worked yesterday and wi 71 get a day off this week for it. They were rushing the work on the gravel pit and needed a powder monkey [a person who is experienced with dynamite]. They are breaking up conglomerate rock and loading it [on trucks] with a gas shovel [front crane] to gravel the road. All I did today was to lay around. Some men came up [from the ma in camp] to work on the gravel pit and I got my mail. I received your letter, the colliers, the criterion, and the Tribune.

The railroad had quite a serious accident,ip/0maha9/ I see by the paper. I also read the Lillian Reznicek is married. 100 . The country back there wi1l be changed quite a bit when I return. I'll bet I notice the wind a lot since the average velocity is only 3 miles an hour here.

You must have had a lot of fun on the coyote hunt. They don't get very many coyotes though. I am feeling fine now and hope this weather continues.

Lovingly,

Norman

99/ Particulars of this railroad accident are not known.

100/ Lillian Reznicek was the daughter in the family that lived immediately north of our old farm.

Camas Valley, Ore. January 11,1934

Dear Folks:

I came down to the main camp tonight as I had a day coming for working last Saturday. I have not received a letter since the one written on New Year's Day but received the papers and the World-Herald and criterion. I enjoyed reading of the [train] wreck. I guess that is going to be an awful expense to fix things up. I fee] fine now and we have had fine weather except for yesterday. It was blustery then and snowed a little last night. It cleared up then and was beautiful today. They say this is exceptionally fine weather. 
I have worked on the gravel pit most of this week and I suppose I will next. They have had quite a bit of trouble with the air compressor. One day we broke every [rock] drill as the points had been welded poorly. I have ran the [jack] hammer some the last few days. This will probably help me some in time to come.

They have seen cougar tracks around camp lately and I suppose I may happen to see a dead one sometime if the hunters come in. A man at Camp Reedsport about 20 miles north of Marshfield was killed and one injured in a [dynamite] blast last Friday. They went back to a misfire too soon. We have to dress up for chow every night now and stand inspection on Saturday.

Well this is all of the news so will close.

Lovingly,

Norman

January 14, 1934

Dear Folks:

It is Sunday afternoon and I am laying in the barracks sleeping and resting. There isn't much to do here on weekends except rest up. I didn't go to Roseburg as there is little to see in that town.

It rained constantly here from Friday morning till this morning. The sun is out now so I suppose we may have some good weather now. I am feeling good except for a slight cold.

I suppose we will have to sign up to stay or go home soon. I have made up my mind to go back to Nebraska if there is any hope of getting a job. One gets tired of this life if there is no fishing or hunting to do.

One hardly knows what to do as the money is the only certain thing here. If a person could get in the Forest Service, the job would be good but we aren't even located on a National Forest here.

I am going back up on the mountain again this week. I kind of wish I was in the main camp steady now so I could fish in the Coquille [River]. The warm days should be good fishing.

I don't know any news at al1 so can't write much. Lieut. Tierney101/ says we wi11 leave here on March 16 for the east if we go back. I received Emerson's letter last week. You must have had a lot of fun hunting this winter. I suppose I will notice the cold when I go back as it has only frosted twice since I came to this camp.

Lovingly,

Norman

101/ Second Lieutant Don. C. Tierney was a Field Artillery Reserve Officer. 
Camas valley, Ore.

Jan. 18,1934

Dear Folks:

I am sitting in the tent listening to it rain now as it has all day. It rained quite hard but let up at noon enough that I took my rain clothes off and got soaked this afternoon. Monday, Tuesday, and Wednesday were fine days and warm. I feel fine now except for a cold I caught this afternoon from getting wet.

I received both Dad's and Mother's letters this noon up here on the mountain. Also the criterion. The camp does not take the World-Herald any more so I don't get to read an Omaha paper. I saw the piece in the Tribune about grandma $102 /$ and also about me. I may go to Marshfield in a week or two as a truck goes about every weekend. When did Emerson get is 14th coon? They continue to say that we will leave here on the 16 th of March.

The army took a notion this week to go through everyone's clothing and check it. If one is short, they charge you with it and take the money from your check of course issuing you replacements. The old wornout clothing from Fort crook which I have discarded, one is supposed to have. They won't look up here so I am safe I believe. I suppose this is caused by some men pawning quite a lot of their clothing.

I have worked on the gravel pit all of this week and I think the CCC money could be spent well elsewhere. If right of way for the roads to be built next summer was cleared and blasted and the snags in the burn felled, we would accomplish far more. Sometimes I think the bosses power here overlap so much little is accomplished. We are just blasting the side of a mountain away and putting it on the road. The rock is not crushed.

When we returned last Monday morning, a big hole had been burned in the mess tent's roof and they put up a cute shake building this week. I am going to take a picture of it if I can.

We11, I will close and hope that I will be seeing you in a couple of months.

$$
\text { Lovingly, }
$$

Norman

102/ I do not know what the article in the Fremont Tribune about my Grandmother Inga Lisa Lundstrom related to. However, any such article would have interested me.

Camas Valley, Ore. January 21, 1934

Dear Folks:

I haven't received a letter since I got the two last Thursday so will not have any to answer. It has rained unusually hard here the last 3 days and I believe the real rainy season must have started. The coast along Coos Bay has had a severe storm and this is the effect of it inland. I sent a Happy Days paper 
and a Myrtle creek paper back today thinking you might like to read them. I see by the paper that Uncle Frank's regime as the head of Omaha's police may not be as successful as possible. What does he say?

Last Friday I worked making small rocks out of big ones as usual. It gets rather tiresome but is cleaner work than some other jobs. One never seems to accomplish anything on that kind of a job but still they have to pay us the $\$ 1.00$ a day. If I stayed another term I would be about the slowest moving mortal living. It commenced raining Friday noon and they didn't have to work in the p.m. at the main camp. I came down to the main camp Friday evening and it is sure nice here now. The road up to the mountain is nearly impassible now.

We were issued swell boots (leather) Saturday morning and I am going to take good care of mine so I can have them when I get home. I have a pair of good loggers I bought for $\$ 3.00$ so I will have a lot of shoes. I ordered a gray army locker for $\$ 3.50$ so it will take most of the month's paycheck. I still have $\$ 4.00$ left from my last check so I have plenty. I am going to save a little every month so I have some when I go back. They took our measurements yesterday and they said it was for army dress uniforms. This is just a rumor though.

They have a fine recreation room now. Two ping-pong tables, checkers, cards, and chess. I sure like to play checkers. I slept in the hospital this weekend and had to take care of it on Saturday night. It sure beats lugging one's bed though.

Well this is about all I know let alone all the news. I feel fine.

Lovingly,

Norman Myers

Camas Valley, Ore. January 25, 1934

Dear Folks:

I have had no letters so I can't answer one. The mail is sure funny. First a letter comes clear here in 3 days and the next on takes 5 or 6 days. I believe this is caused in the main camp as I always get them on the third day. It has been all of a week since I received the last ones.

It rained hard on Monday and Tuesday and cleared off fine the last 2 days. I am feeling fine now. There is a pretty snow cap a few miles south of us. Quite a bit happened this week. The boss had his arm broken and a kid got two fingers cut off at the pit today.

Monday evening Bob Stough, our boss, and I lit about 15 shots and beat it from the gravel pit. A shot went off soon as we were about 50 feet from it. I ducked behind a big fir and the boss stood back of me with his arms above my head. All at once something banged my head and he yelled "my arm's broken." A rock which weighed about 10 pounds broke hjsarm just back of his wrist. It was lucky that it didn't bean either of us 103 . A kid got his finger under a cable which he had hooked on a log. It squeezed two fingers off and they had to take him to camp this afternoon. 
They have been sending up gelatin [a special nitrate based dynamite called gelignite] to load with this week. It loads nicely in rock and the water doesn't affect it at a 11. It packs in the tightest of any powder. They got a new [jack] hammer in today and it works much better than the old one. A hammer works about 6 months and is worn out.

I see that the World-Herald has abou' said the police administration is no good. Which could be expected. I wonder what the Bee says.

\section{Lovingly,}

Norman

103/ Forestry Foreman Robert Stough possibly saved me from serious injury by having his arms over my head while he stood back of me. His injury was so serious that he did not return to work prior to my leaving to return to Nebraska. I cannot explain this premature explosion of dynamite. It may have been the result of a "running fuse." These fuses uniformly were cut long, a procedure which normally should prevent such an accident.

Camas Valley, OR January 28, 1934

Dear Folks:

Well we sure had a fine day this Sunday. We have all the doors open, no fire, and the sun shines brightly. I played ping ball for several hours this p.m. and got up a sweat and followed it with a shower. Yesterday, it was cloudy and cool and Friday was just like today.

Two of the rookies got mad at each other day and agreed to fight it out today. They both ate a big dinner and fought right after it. It was sure a scream. Both were bum and I think they decided who is the poorest fighter in camp.

I came down off of the mountain last Friday evening. They hauled out 100 loads of gravel again Friday. I like our new boss well and he is much more careful than the old one. I set off the shots Friday noon and didn't have to even go out this p.m.

I cancelled my locker order as they sent a sample and it was not much bigger than a suitcase and not the regular army locker. I am sending you several more clippings from the Roseburg paper which may be interesting.

I have made up my mind not to sign up again. I would have to stay another year and that would be too long. I believe it is best to go home now anyway.

I saw in the paper about Hank Bronson's death104/. I received your letter Friday evening. We11 Emersom caught 15 coon this year which is sure good. The Oregon farmers are planting their spring grain now. I believe spring must be about here now. 
Well this is all the news so will close. I feel fine.

Lovingly,

Norman A. Myers

104/ The Bronson family lived near our's in Fremont.

Camas Valley, Ore.

February 1, 1934

Dear Folks:

I have received two letters, one yesterday and one today. The one you mailed on the 29th I got up in the side camp today. This is fast for common mail. Tomorrow is Ground Hog day but I am afraid he will see his shadow. We have had wonderful weather lately. I can hardly believe that it is winter. It has been awful hot in the middle of the day and one sweats quite a lot. I have been working with my shirt off lately.

We have been having a lot of fun in camp tonight. They have been tearing up bunks, wrestling, and fighting. I have sure been in a lot of it too. I have had a fine time this week as we are outside a lot. I am coming back I am sure as I am quite tired of camping out. I'll have to start in private life sometime anyway.

I sure enjoyed Emerson's letter. He must have had a lot of sport hunting coon this year. I will be home in time to fish anyway. I am going fishing down on the Coquille if I can get any worms by Saturday morning.

I have worked on the gravel pit al1 week. During January they hauled out 1,000 loads of rock from the pit. They keep spreading it thinner and thinner all of the time so I suppose the road will break up when it rains.

We11, I am out of news and it is late so I will close.

Lovingly,

Norman

Camas Valley, Ore.

February 4, 1934

Dear Folks:

Well it is Sunday night again. I have been in Marshfield this weekend and enjoyed myself. It is sure fun to monkey around the waterfront cities. I sent you three papers from there and you should get them before this letter. I arrived back late this evening so I am writing this in the hospital as the taps have blown. We had trouble with the truck and it got worse and worse till we had to walk the last $\frac{1}{2}$-mile back. It has a blown gasket I believe. 
I have been feeling fine and am getting over my cold. I weighed myself with OD's [winter wool clothes] on and one scale said 181 and another 184. I hardly think I have gained that much. I ate some fried clams this noon and they sure tasted good.

We left camp after dinner Saturday noon and arrived in Marshfield about 4 in the evening. A ship was docked there, the Barbara C., and we looked it over. I went into its engine room, cabins, and in fact everywhere. They sure keep it clean and the bunks are all made up exactly alike. The run of this ship is from San Francisco to Portland. It seems monstrous when one gets aboard even if it only is a 1,500 ton vessel. The crew is all Swedish.

I went to the movie and listened to the dance music in the evening. One of the boys, an amateur preacher, got drunk for the first time and was sure comical. He said he would never do it again and made us all promise not to tell a one. The Lieut. in charge, a darn good sport, passed out on the dance floor and I got a coal pail for him to heave into. He wanted to go outside so I led him and he threw up all across the street. Then he took a bunch of the CCC's to sober up on beer(?) A member of another camp stole his hat and the kids had to lick him to get it back. Then the two companies were to have a gang fight, but it all faded out. I went to bed then so I didn't see any more of the fun.

This morning I got up early and walked down to the waterfront. It is sure pretty. The gulls fly lazily over the waves, the sawmills smoke ascended straight up, and the sun glistened in the ripples. Back of all of this is the cedar covered hills. The trees are much prettier than those in the mountains. They all are Port Orford cedar, spruce, hemlock and a little fir. Occasionally a motor boat would putt-putt by. I rode to North Bend and back on one for $20 \phi$ and also a short ways on a milk boat. The milk is all collected by boat. The depression seems to have affected these cities a lot and about $\frac{1}{2}$ of the buildings are empty.

At noon we went out to the lighthouse. They are building a new one now. A number of fishermen had made fair catches there fishing off of the rocks. The sea was unusually light today. We looked around for shells quite a bit and I found an unusually good one. The tide was in so didn't have much chance of finding much. At 5 p.m. we started for camp.

I came down from the mountain Friday noon as I had a half a day coming. They paid us that evening. The commissary is $\$ 128.00$ short this month so they canned the store keepers and are to put in another. We sure will lose a lot on it this month. I believe that someone must have hooked [stolen] some of it.

The work on the mountain was fairly good last week. We hauled about 500 loads of rock from the pit. The rock seems to be getting deeper on the west end so now there is too much dirt over it to use it. They are going to move the pit toward camp. Well I only have about 2 more weeks to work there and it will go fast. The rock is changing from conglomerate to a hard blue rock.

I received the Criterion and your letter last Saturday, also I forgot to mention the tramp's card some time ago. It was sure funny. The picture of the coon is good. It is late so I will close.

Lovingly, 
Camas Valley, Ore.

February 6, 1934

Dear Aunt Hannah and Helen Inga Violetta:

I received the box of candy last Friday and thanks a lot for it. I am chewing some of the gum now. I am up at the Buck Springs side camp yet. Of late I have been working in the gravel pit making small rocks out of big ones.

The weather has been very fine here lately. It is clear and warm and I hope it keeps that way for a long time. Last Sunday there were over 3,000 people on the beach at Bandon by the sea. It hasn't rained for a couple weeks and I suppose that I am knocking on wood. There hasn't been much snow or cold weather so far only frosting a couple times this winter.

Last weekend I went to Marshfield and Sunset Bay. I sure had a good time. I went through a steamer which was in the docks. The dock about $\frac{1}{2}$ a block from the main drag in Marshfield. I rode a lot on the bay in private boats as they don't charge anything. They haul all the milk into those towns by boat. I like to hang around those towns and just watch the boats. Some of the fishermen had made good catches.

I am feeling fine now except that I have some barbers itch on my face. It has been spreading quite a bit even though the Doc. gave me some salve for it. I was weighed in town last Saturday and weighed 181 pounds. I hope I get over the itch before I go home.

I am banking on coming home in 2 months. They took all of our names down on Civil Services applications today. I told them I wanted a forestry job. I received Helen's letter several days before the package arrived.

It is late so I will close.

Yours truly

Norman Myers

Camas Valley, Ore.

February 8, 1934

Dear Folks:

I received a letter, the Criterion, and the Tribune today. Swartz's picture is sure good. There seems to be quite a lot of news now in the papers. Emerson got a good price for his coon I think.

The good weather has finally broken and the rain started yesterday. It sleeted and snowed this morning and cleared up this afternoon. Monday and Tuesday were fine days. 
I still have my mind made up to come back in the next load. If I stayed till next fall, I would have to stay all winter. I am feeling fine now except that I have four spots of barber's itch. It is awful hard to cure. I have two big spots of it, one medium, and one small. I hope the doctor can cure it by the time I go back. It sure has spread to beat the devil.

They took all of our names down and the job we were good in this week. The Government is trying to find some of us jobs. There is practically no chance as there are $1 / 3$ of a million $3 C^{\prime} \mathrm{s}$. I put down forestry. I told the boss I wouldn't choose dynamiting as I am sure it means an accident sooner or later.

I have been working in the gravel pit all week. I start to work at 1 p.m. and load drill holes till they quit work at 4. Then we shoot the shots and drill the boulders and shoot them. They said that I was rerated at $\$ 36.00$ according to the bulletin board this week. That will give me a little extra to spend going back.

We11, I am out of news so will close.

Lovingiy,

Norman

Camas Valley, Ore. February 11, 1934

\section{Dear Folks:}

It is Sunday evening now. It has been a fine day. I played catch for a while this afternoon and then we got up two teams and played pug ball. It sure seems funny to have this weather this time of the year. It is quite cool at night but warms up in the daytime.

My itch seems a little better. One spot is clear gone and two others a lot smaller. The big spot is still spreading some. I feel good though. They always have fine meals for us on Sunday.

A lot of the men are going home now. Four left yesterday and about a dozen are going home wednesday. This outfit is mostly haywige. The National Forest is much better in its management than the $0 \& \mathrm{C}$ lands $105 \%$. It seems strange that they don't get the best out of the men.

I came to the main camp Friday evening. We sure blasted a lot of rock down on Friday. They held a dance here on that evening. It was well attended by the girls and most of the men got soaked. I can't see how some of the men in the high pay class can afford to get drunk and stand a chance of losing their job like they do.

I received Ruth's letter last Friday. Swartz's picture was good. I also received the [basebal1] magazine. I am sending a roll of film to you. I figure that I owe you $\$ 35.00$ for the stuff I have had sent out. I sent my fishing rod home yesterday and will send my horn before I go. I won't have to carry the stuff around then. I still intend to come back as this is a screwy camp. 
Well this is all the news so I will close.

Lovingly,

Norman

105/ O\&C Lands stands for Oregon and California Railroad Grant Lands. These tracts were granted by Congress to the Oregon and California Railroad Company for constructing a major railroad line through this area of Western Oregon. The Southern Pacific Railroad Company acquired the O\&C Company and the grand lands in 1887. Many legal and legislative actions have been based on these land grants.

Camas Valley, OR

February 15, 1934

Dear Folks:

It is Thursday evening now and I am writing this in the tent by lantern light. We have had fine weather this week till today. It has been cloudy today and started to sprinkle this evening. I am feeling fine now and my itch is a lot better. I have only a few small spots on my face now but I also have a slug of big pimples on my neck now. In an outfit like this, one gets everything going.

I have been working at the gravel pit all week. We have had good luck with our work this week. Tonight we shot about half of the mountain down. One of the rocks took four drill holes in to break it up. Occasionally we strike coal in the rocks. One vein was about 3 inches wide but soon petered out. We figured it up and it takes about 1 pound of dynamite to shoot a cubic yard of rock out.

I received your letter on the 12th. Also the clippings from the World-Herald. You get two letters each week from me, don't you? I send one each Sunday evening and Thursday evening. I always tell you of everything I get.

The young folks including Harvey Klintworth are sure getting married. Emerson must have had a fine time at the dance of Edd's. Does Uncle Frank think there is any chance of getting work back there? I don't see how one can help himself by staying in here except by getting $\$ 1.00$ a day and three square meals.

They have made a new camp up at Live Oak and I guess I may move up there soon. I am going to send my horn home as it is hard to move around.

We11, it is late and I don't know any more news so I will close.

Lovingly, Norman Myers 
Camas Valley, Ore.

February 18, 1934

Dear Folks:

It is Sunday evening again and I had a lot of fun today. It rained this morning but cleared off warm this afternoon. The rain quit Friday morning and the weather has been fine until now. I didn't go anyplace this weekend as I an saving my money again. I will have quite a little for my trip back. I feel fine now and my barbers itch is nearly cured. I boiled by razor and brush this weekend before I shaved. The Doctor mixed up some dope that just seemed to be like vaseline but it sure did the work.

I worked up at the gravel pit again last Friday. They got some red dynamite in now. They have more kinds of dynamite than I ever dreamed of. We sure have a high ledge now. They don't have brakes on the trucks and one stopped near the pit. Another behind it couldn't stop so is wrecked it quite a bit. As usual they blamed the driver but I sure don't see how either of them could have averted it unless their brakes had held. They asked me (a foreman) who was to blame and I said neither. I also said it was idiotic to have trucks in the mountains without brakes. I don't care what I say as I am going back.

I came to the main camp on Friday evening. I always get sick riding in the back end of a truck on the rough roads. The Rotary club of Roseburg gave a splendid program in the recreation hall in the evening. One thing that is true is that the Oregonian people are hospitable. They had a local magician who was exceedingly clever. He sure pulled some fast ones on some of the kids. They brought some fine singers.

They have announced that the time for signing again is next Thursday. Unless the next letter says differently I am going to sign to go back. One hardly knows what to do. If I sign up again I would have to stay a year and then I would have the same problem again. Of course, a job is a job and I would hate to be out of work anymore. However, I would like to try to get a job in private industry if possible. If one does not sign again, he can never get in the CCC's again. Only four Fremont men are in the camp now. Only one thinks that he might stay.106/know I can at least exist and if I can't get a job I can husk
corn next fal 1 .

The S.P. [Southern Pacific Railroad] is making a great bid for traffic here now. For $2-1 / 10$ cents a mile they will sell tickets which include the pullman seat and berth and meals in the dining area for every meal enroute. Quite cheap I would say. I hardly can see how the country can dispense with its systems anyway.

They don't say they know when we will get back but the paper says sometime between March 31 and April 15. I have earned quite a bit out of this so far, about $\$ 200.00$ I suppose. There is no chance of finding a job out here wi thout pull or a lot of luck. 
I am sure getting better at checkers now. I can beat anybody I play. I sure skin some of the old champions. I just move the men without thinking and get some three for one trades. I suppose if I practiced a lot I could beat some of the good players in Fremont. I walked down to the Camas Valley store yesterday and mailed my horn home. Tell me if the fishing rod and horn gets there. I insured both of them. They flowers are blooming in the valley. The poppies are beautiful. I have some seeds I collected at Drew to bring home.

I received the letter of Dad's and the Criterion the last of last week. What are Emerson's hours? Do you think that the administration would have ditched the air mail contracts without cause? If one can invest $\$ 259.00$ and get a paper return of $\$ 35,000,000$, the subsidy is too high. The Replublicans claim that they didn't cancel the contract of the PanAmerican Airways because of the Democrats at the head of this concern. Did the Republicans give the contracts of all the American lines only to their own politicians? I sure back Roosevelt on this squabble. Of course, every team will have its crooks and they should be treated rough.

They will give no furlough to go home the CO [Commanding Officer] says. I believe the return trip is by special train via Roseville, California (just east of Sacramento).

Lovingly, Norman

106/ In 1934 most corn was still husked by hand in Nebraska. Currently it is harvested mechanically.

Camas valley, Ore. February 22, 1934

Dear Folks:

I canie down to the main camp this evening. We worked today and will get tomorrow off. It has been cloudy and cool all week and fine weather for working. I am feeling fine now and my itch is about gone.

I signed up to go back Monday morning before I went to work. Most of the men signed to stay but I couldn't see it that way. I know times are still hard back there but I don't believe too much of this kind of work pays a man. About 130 have signed to stay and 50 to go back. They change their minds all of the time and change their decision.

I moved up the road to Live Oak, about 2 miles farther up the mountain from Buck Springs, to the new side camp. They are falling and clearing the rightof-way up Chipmunk Ridge ahead of the bulldozer. I have been shooting stump, and slooping banks mostly this week. There are quite a number of hemlock in this locality. I fell timber for a half a day. I only had one tree go over backwards for me. I forgot to tell you only one of the four Fremont men is to stay another six [months]. 
I received two letters and a lot of clippings from Dad this week. I probably won't get another till next week. You don't have to send any pictures out as I will see them back there.

We11, this is all the news so I will close.

Lovingly, Norman

Camas Valley, Ore. March 1, 1934

\section{Dear Folks:}

I have received quite a bit of mail this week. One letter from mother, one from Dad and the Criterion and clippings. It hardly seems possible that it is March already. It wilT on $7 y$ be a month and I'll be back. I feel good now. Most of my itch is gone and I think it will all leave by the time I get back. The weather must have turned about face on you now the way the paper reads. The airlines have sure had some bad disasters. I hope you will have luck hunting in this snow. It has been fine weather here this week. Yesterday was beautifut. Tonight it has started to rain. I hope it don't keep it up as I am going to the main camp tomorrow night. I received a letter from Russell [Heese] this week and he is in Norfolk with Coon Schiferl.

You must have had a good talk with Corcoran (we called him Hoosey). He went home the lasty of September. Ray Sic has sure had a tough time with the operation- I see by the paper that Ames is to have a ball team again this year while Fremont's team is questionable.

Uncle Frank has sure got into a peck of trouble. The clippings were sure appreciated. I just sit and think and then know less about it. I believe that the common people know little of what goes on in the cities.

I have been blasting stumps 211 week. We have made good headway down Chipmunk Ridge this week. They made nearly 1 mile of road in February.

The present rumor is the Co. 757 is to be moved to Salem, Ore. for the summer. I won't be along so it doesn't make much difference. The fallers fell a tree with 377 growth rings in it. This tree was a seedling in 1556. Quite old.

Well it is late so I will close.

Lovingly,

Norman

107/ Raymond Sic was a friend of the family and he was the catcher for the Ames Basebal1 Team. 
Dear Folks:

I am sitting in the barracks now resting. I played some pugball, catch, and then a few games of chicken. It is nice and warm now so I don't think it will hurt my arm. If I am in Fremont this summer you can tell Sic's I would play with them. I see by the paper and your letter that Ray is better. He sure has a lot of trouble.

We had the usual good dinner this noon as they always have a fine meal on Sunday. It rained quite a bit yesterday and today while Friday was clear. It seems unusually cold. I don't believe that it will snow anymore. I am feel ing fine now. I have a few spots of itch left but they are small and I hope vanish before I leave here. They have body itch and measles making the round of the camp now. Quite a number of men left for home yesterday. They leave at the rate of about five a week.

I believe we will leave here in about 3 weeks. I am going to get my clothes cleaned and pressed so I will look half decent. I will have a good pair of pants and three OD shirts.

I believe that I will go up on the mountain again this week. They broke all of the rated men going back so I got busted. Nick Laudenklos got my rating and he is tickled. I am still blasting stumps down Chipmunk Ridge. The bulldozer has struck a lot of rock so we won't go so fast now. They say that there is a lot of virgin timber about a mile farther out.

I received dad's letter Friday. I will send the next S.P. ad I see. A sample rate is $\$ 16.50$ for Portland to San Francisco which includes pullman and three meals. The distance is 772 miles. A CCC can get $\frac{1}{2}$ fare for everything on the railroad so one nearly has a pass. The weather sure has caused many accidents lately.

Well tell some of the Ames hypes I will play with them. I believe we will have a special train going back.

Lovingly,

Norman

Camas valley, Ore. March 8, 1934

Dear Folks:

It is Thursday evening again and I am writing. I received the first mail up here this week today and I had four Tribunes and dad's letter. Also one from Tommy Starmer. We have had some fairly good weather this week. It rained quite a bit Monday but cleared off fine and cool. It froze a lot of ice on the trees that night and when it thawed off Wednesday a.m. was worse than rain. Then it cleared off fine in the afternoon and was fine today. The sun shining on the clouds below us was pretty this morning. A small peak below us stuck up 
through the clouds like an island.

I came up to the mountain on Monday morning again this week. I have blasted out on the right-of-way again this week. We have made fine time so far. So far this week we have gone 4,000 feet. There is a man working with me and he is darn good. We got in 73 shots yesterday and about 60 today. We are so far from camp we eat our lunch out where we work. They are going to move the camp out about 2 more miles next week.

Sometimes I wished I had signed to stay but I still think it is best to get a job back there. This camp is to be transferred to Idaho for 3 months during the summer to fight the pine blister [rust disease].

I see that the new stream lined train is out now. I wonder how successful they will be. I believe that too much importance is put on speed. One sure can see as many sights going slower. I can't see much occasion for such speed except for emergencies.

I see Omaha is quiet again. One is a bum one week and a good guy the next. I am feeling fine now.

Lovingly,

Norman

108/ Tommy Starmer was a neighbor of ours while we were on the farm.

Camas Valley, Ore.

March 11, 1934

Dear Folks:

I won't be here many more Sundays any more. I believe I might be home for Easter Sunday which would be fine. They sent out a new order which says all men enl isted last spring and summer must quit or by discharged by June 30 . I am glad I will get out now instead of June as I hope there is more chance of a job.

They say a train is to be made up at some terminal here and a special train is to take a group back. I believe that tickets will be furnished to Fremont. I am getting my uniform cleaned and pressed for the trip now.

This was sure a fine day. It must have been 90 in the shade in the valley. I played a lot of catch and am getting my arm broken in. They tried to get a pug ballgame going but hardly anyone would play. Some sports. I am feel ing fine now. I changed to my light underwear yesterday. This is perfect weather for baseba]1. I don't see how Nebraska can have a better climate than here.

I will bring some fern roots back when I come. Last night a drunk came into the hospital and I had to sober him up. He sure vomited over everything. It is sure disgusting to see a person drunk. I received mother's letter last Friday. 
Last Friday we blasted some more up the road. I came down last Friday evening. They are going to move the camp up the road 2 more miles this week.

We11, it is late so I will close.

Lovingly,

Norman

Camas Val ley, Ore. March 15, 1934

Dear Folks:

It is Thursday evening again and I am in the tent up at the side camp again. It has sure been a nice week and I hope this weather keeps up. I haven't seen a finer March in my life than this has been. I am feeling fine now and suppose that I will till I come back.

I came up to the side camp up here Monday morning and have blasted stumps out on the road toward Dutchman's Butte al1 week. We are over 2 miles from camp now. We have sure had good luck lately as we have gone as far as 500 feet in a day. Last evening I walked up to Live Oak and looked out on this state again. There are quite a number of snow caps around and some are most beautiful. We can see Mt. Jefferson, the Three Sisters, Mt. Bailey, Mt. Pitt [Mt. McLoughlin], and Crater Lake. The whole Siskiyou range is snow covered.

My mail came last night the Tribune, Criferjon, and dad's Tetter. That gas valve must have sure made a lot of noise. I would let the ball team go under if a town had to raise $\$ 750.00$. There must be a lot of sickness everywhere. Two men in our tent went down to the ma in camp Tuesday with the measles. I suppose I may get them.

There have been a lot of rumors here about everything. They first said that al1 Nebraska men go back to the 7 th Corp area. They now say that we go home on March 29 and this camp goes to Drew for the summer. Nobody knows anything definite.

Well I will close as it is late.

Lovingly,

Norman

109/ A major pipeline carrying natural gas from the south to the north passes just west from Fremont. Occasionally it will blow up resulting in a terrific noise. 
Camas valley, Ore. March 18, 1934

Dear Folks:

I received your letter last Friday. I have lost it so can't answer anything you asked. The weather has been fine lately. I am feeling fine too. I sure am getting sunburned now.

I played in the ballgame against Camp Bradford today. We lost 6-1 but they didn't play extra hard. I played second base and got to bat twice. I hit a triple over the right fielder's head the first time up and struck out the next. The weather was ideal for baseball.

We started to work early Friday morning and came down to the ma in camp by 3 p.m. They held a dance in the Recreation Hall in the evening. Everyone had a fine time and we had quite a number of topers [drunks] to put in bed. We are going to work up at the side camp again this week, I believe. Time sure goes fast when one is in a side camp.

We are going to leave for Nebraska on March 29. We will arrive about on the 2nd of April. I will come clear home on the train as I will have a pass. We are going on the S.P. [Southern Pacific] to Sacramento-Ogden; D\&RGW [Denver and Rio Grande Western] to Salt Lake City and Pueblo; M.P. [Missouri Pacific] to Kansas City-Ft. Leavenworth-Ft. Crook. We will have a swell trip back. These dates aren't sure yet. I will be home soon after Easter anyway.

We11 I went into Roseburg last night. I saw the "Marx Brothers" and it was so silly it isn't worth seeing.

Well this is all the news.

I'll be seeing you,

Norman

Camas valley, Ore. March 22, 1934

\section{Dear Folks:}

Well if what they tell us comes true in one week from tonight we will be going over the big Cascade [Range] hump. They say we will leave Eugene on the 29th at 4 p.m. We have to turn in about all of our clothes so I will not have much in that 1 ine when I come back.

I am up in the camp at Live Oak again this week. We blasted out on the road up Chipmunk again this week. Today we shot the last 2,500 feet up to Live Oak. They are rushing this road so it can be used to haul the new lookout house up to the peak. One couldn't see much today as the sky is rather hazy. On Monday, Tuesday, and Wednesday we worked up a couple more thousand feet up the ma in road. We shot from 482 to 591 on this main road during the last month. This is 10,900 feet and it sure is a lot of stumps. Then we have shot 2,500 feet up the branch to Live Oak. 
They are calling in all of the side camps tomorrow. They say that all of the men will be transferred to the $7[\mathrm{th}]$ Corps [Area] and by the first of April, any man who has served less than 6 months may choose to transfer to another camp out here. I guess all of the foremen are to be transferred to a road camp at Tiller.

The weather has been nice this week. A thunder storm came last night and hit the telephone line. It burned our telephone out. It is sure warm yet. I am feeling fine now and just got rid of the last spot of itch this week.

During the weekend someone came up here and stole a good falling saw. The people sure steal anything now.

I haven't received anything but the papers so far this week. Well, it is late so will close.

Lovingly,

Norman

Camas Valley, Ore. March 25, 1934

Dear Folks:

This is the first time I have had to write you today and it is quite late. I received your letter sent by air mail up on the mountain Friday morning. One cannot tell anything about the mail service up there as it comes spasmodically. This will be my last letter of any size before we leave here. It kind of looks as if Fremont may not have a [basebal1] team this year, doesn't it. I hope Ames has a good team.

We have had splendid weather lately. Saturday it rained all day but as we didn't have to work it wasn't so bad. It is prefectly clear now and fine to be outside. I am feeling fine now and the sickness in camp seems about over. They are to move this camp very soon. Some are to go to Melrose rest back to Nebraska.

I played baseball both yesterday and today. I got a pair of hits yesterday out of three times up but only got one hit [today]. This was a home run beyond the center fielder into a prune orchard. We beat Camp Bradford 6-2 yesterday and our team won 24-5 today.

I have to check in my clothes tomorrow morning and also show them all that is to be returned to the Fort. I don't believe that we will do much work next week.

We are leaving here so that we can eat dinner in Eugene Thursday noon. We leave Eugene at 4 p.m. I have not much idea of when we will arrive home. We march three times a day and have to stop to eat about three times too. We may have to stop quite a while at Fort Leavenworth [Kansas]. We may arrive home on Monday. I believe I may stop a while in Omaha on Monday if we arrive then. 
We11 I am dry of news so will close.

As Ever, Norman

110/ Camp Melrose housed a CCC Company in Oregon.

Camas Valley, Ore. March 28, 1934

Dear Folks:

We11 I am al1 packed ready to go tomorrow. I have been awful busy today. We had to take the rented piano into town this morning to return it to the junk dealer. I hope that tomorrow is nice as I want to take a number of pictures. We leave camp at $8 \mathrm{a} . \mathrm{m}$. The train leaves Eugene at $4 \mathrm{p.m}$. I'7l bet there will be plenty of snow in the Rockies. I will get back sometime after Easter and you can't expect me till the evening of the 2 nd. I have no idea how long we will be detained at Ft. Leavenworth.

I received Dad's last two letters yesterday. You sure had a good time hunting coyotes. I see by the paper that you have gotten quite a bit of moisture lately. There has been stomy weather all over the Pacific Coast last week. It has rained here the last 4 days.

We11, I am getting ready for our feed tonight. It is going to be swel1. It doesn't seem possible that a long trip is ahead but I am sure glad.

Lovingly,

Norman

Wi11 write at Ogden. 
Return Trip to Nebraska

The train ride back to Nebraska was better than the one from Nebraska to Oregon the previous May. Two old dining cars manned by CCC personnel were used to cook and serve the food. On the westbound trip the cooking was done in baggage cars. All sleeping cars on both trips carried the normal 12 sections with one drawing room configuration.

After leaving Eugene, Oregon about 4:00 p.m. on March 29, the train passed through Klamath Falls and Dunsmuir arriving at Roseville, California, shortly after daylight. Roseville is a junction point about 20 miles east from Sacramento. A long stop in Roseville allowed men to examine the huge Southern Pacific locomotives with their cab on the front. One of these locomotives was placed on our train and the ascent of the Sierra Nevada Range began. This was a real show with both the locomotive and the American River Gorge to watch. The train did not stop at Reno but layed over some time in Sparks, Nevada, one of Reno's suburbs.

At Ogden, Utah the train was taken over by the Denver and Rio Grande Western Railroad. The trip continued through Salt Lake City and the beautiful Colorado Rocky Mountains and the Royal Gorge to Pueblo, Colorado where the Missouri Pacific Railroad took over the operation for the final leg of the journey. Stops were made at Fort Leavenworth, Kansas for discharge of a large number of CCC veterans and then at Fort Crook, Nebraska, the final destination.

Upon being discharged on Monday, April 2, I received a pleasant surprise. A11 monies due were paid to the enrollees instead of the major share going to the dependents, and in my case the higher rating was contirued until my discharge.

While my $10 \frac{1}{2}$ months of service in the Civilian Conservation Corps was ended on Apri1 2, 1934, this experience affected the remainder of my 1 ife. In retrospect it now appears to have been a long, learning period for those citizens in the Corps during a critical period in our Nation's history. For the opportunity the Government gave me in 1933 and 1934, I am deeply grateful. 
The enthusiasm of the Nebraska men chosen as members of the Civilian Conservation Corps was evident in May of 1933. Much of this is a reflection of the economy in this area at that time. For example, the assets totaling $\$ 877,477.76$ of the Beemer State Bank, Beemer, Cuming County, Nebraska, we re sold for $\$ 1,000.00$. Oats, corn, and wheat were $10 c, 12 c$, and $32 c$ per bushel, respectively; eggs were $8 c$ in trade; broilers and ducks were $5 c$ a pound; geese were $3 c$ a pound; and hogs were $\$ 1.50$ per hundred pounds. In many instances the charges for transporting livestock to Omaha exceeded the selling price of the animals. As a result, few jobs we re available.

The CCC project gave citizens hope. This is best reflected by a quotation from an article in the Burt County Herald, Tekamah, Nebraska, issue of May 18, 1933, that reads: "Twenty-nine cheering Burt County boys left the courthouse in a flag-bedecked truck about 10 'clock Monday morning bound for their temporary camp at Fremont. The boys were enthusiastic over their forthcoming adventures and they waved a happy good-bye to relatives and friends who gathered to see them off."

Several interviews made recently of members of the original Company 754 of the CCC program are evidence that this enthusiasm still remains. The following pages relate information about each man's CCC enrollment, what he thought of the Corps, and something about his later life.

George Fowle entered the CCC when he was 17 years of age, one year too young, by incorrectly giving his age. He did not see too much service and departed at the end of the first six-month term.

The original CCC assignment for George was under Foreman Vernon Poole in the Fire Crew. This crew did some work on trails and while so employed George was injured while trying to roll a log. A substantial amount of time was then spent in the Veteran's Hospital at Roseburg. Upon returning to duty he was sent to the South Uimpqua Falls Side Camp where he helped cook. It was with pleasure that George recalled visiting both Crater Lake National Park and the Pacific Ocean while in the CCC.

The group with which he returned to Nebraska traveled on a special train to Portland and then on the Union Pacific Railroad through Oregon, Idaho, and Wyoming to Nebraska. After returning home, George was a brakeman on the Union Pacific Railroad for five years and then a switchman on the Chicago and Northwestern Railroad until retiring several years ago.

Herman J.Hosch, Jr, remained in the CCC camp at Drew for only a short time. He thought the lack of food was unbearable and he, with another member, August Horne, returned to Fremont, Nebraska.

Hosch told of the men at Camp Drew hocking their personal possessions, of which they had few, to walk to the little country store at Drew to purchase food. Later, when he saw no improvement in the rations, he said he just up and left the camp. He also mentioned that he was on KP for the entire time he was in the CCC at Camp Drew. 
Hosch and Horne first hitch-hiked to Grants Pass, then rode on passenger trains by standing between the cars to either Portland, Oregon, or Seattle, Washington. It was from one of these two cities they started riding freight trains back to Nebraska via Spokane; Billings, Montana; Alliance, Nebraska, where Hosch had relatives; and finally to Lincoln, Nebraska.

While returning, they visited the Salvation Army or some other relief agency where they cleaned up with a bath and ate since neither Hosch nor Horne had any money. Upon arriving at Billings, Montana, he recalled that hundreds of men were in the railroad yards just awaiting a freight train to take them anywhere. It was a reflection of there being little or no work at that time.

Harvey Klintworth was standing in a formation at Camp Drew shortly after his arrival when Gene Rodgers, the Forest Service District Ranger for the South Umpqua Ranger District, asked, "Does anyone here know anything about horses?" Harvey said he did for he was raised on a farm. That set Harvey's course for his entire term in the CCC service.

Harvey and his trusty horse led strings of pack mules all over the mountains. The packing of food and supplies was always done with mules as there were very few roads in the Umpqua National Forest at that time. On some occasions he led as many as 20 mules in a single line. These trips took him to Devils Knob, Butler Butte, Pickett Butte, Anderson Mountain, and elsewhere. These mules packed water in when the men fought fires, dynamite into the difficult areas where roads were under construction, and lumber and various supplies to the sites where lookouts were under construction. These mules were kept at the Summit Ranger Station which was near Camp Drew.

On one occasion Harvey recalled that he thought he knew more about the trails than his horse did. He was returning to Camp Drew when he and his reliable horse came to a trail junction. At this point the horse wanted to go one way whereas Harvey knew a trail leading in another direction was correct. After forcing the horse onto the trail and traveling for a long time, Harvey found he was lost. Then he just left the reins loose and let the horse go where she wanted to go. It was late that evening when Harvey and his horse arrived at the Summit Ranger Station. But the horse did show him that she knew these mountain trails well.

An unusual happening occurred on the evening of June 26, 1933. Harvey was riding in a truck loaded with CCC men when it was stopped by a local resident. This irate character alleged that some member or members of the CCC camp had stolen his home brew. He then incorrectly identified the white hatted truck driver, Richard Trannum, as the culprit. When "Pork" Pateidl, one of the CCC men, saw the man was holding a pistol which was pointing at the truck, "Pork" dove to the floor of the truck and put an empty dynamite box between the gunman and his face.

Harvey stayed for only the first six-month enrollment period. It was his opinion the CCC experience was wonderful.

From 1943 until 1946, Harvey served in the U.S. Army Corps of Engineers, being discharged a Master Sergeant. His overseas service was in the Pacific where he took part in the Leyte invasion. 
Most of Harvey Klintworth's life was spent after his return to Nebraska working for the H. P. Lau wholesale grocery firm which later became part of the Nash Finch grocery firm. Currently, he is semi-retired and lives in Lincoln, Nebraska.

Joseph A. Nielsen worked as a mason and carpenter in private life before he went into the CCC organization. He mentioned that the CCC company from Camp Drew constructed a lookout on Anderson Mountain, from which they could view the rim of Crater Lake. This would have been the most remote side camp from the main camp at Drew.

In the fall, when it started raining on Anderson Mountain, the men had to return to Camp Drew. The return trip made via truck trails through Crater National Forest, now the Rogue River National Forest, required two days. The trail was so slippery a trench had to be dug on the upper side for those truck wheels. It was the only way they could keep the trucks on the narrow truck trail.

Joe also worked on the Butler Butte Lookout, the construction of buildings for the CCC camp coming to the South Umpqua Falls site, the construction of buildings for the new CCC camp coming to Devils Flat, and at both the Buck Springs side camp and the main Camp Remote Company 757 near Camas Valley, Oregon.

Joe reenrolled with the CCC's in the spring of 1934 and his company was transferred to the Tigerville Camp at Hill City, South Dakota. He then became an Assistant Leader in this Forest Service operated unit. In the spring of 1935 Joe again was transferred. This was to Camp Alcester, a Soil Conservation Unit at Alcester, South Dakota. He then was promoted to the position of Leader. During the fall of 1935 this camp was transferred to Camp Crowley Ridge, Arkansas. It was returned to Camp Alcester in the spring of 1936 where Joe stayed for the final year of his CCC service.

Joseph A. Nielsen believed he learned a great deal in the CCC that helped him in his later life. He thought it was the best time of his life. His overall evaluation of the CCC was it was a fine organization and "we just kept busy working."

The World War II period found Joe within the service, first with the 90 th Infantry Division. Then he was attached to the Fourth Infantry Division on " $D$ " day and went into Utah Beach with the third wave of troops. He continued fighting until the end of the war except for periods of hospitalization. Joe was first wounded at St. Marias De Lius in Northern France and later in the Battle of the Bulge where he was with General Patton's Army. His wounds were in his upper left arm where the bullet broke the bone, his left hand, and both legs. His war disabilities were rated at 40 percent. For the remainder of his life Joe was involved in the construction industry in the Fremont, Nebraska, area. He always had the reputation of being an excellent workman. He retired from work and resided in Fremont. Jospeh A. Nielsen died on May 30, 1983.

William Pateidl, Jr. and his parents were without work when he enlisted in the CCC. He recalled the train trip from Nebraska to Oregon as one of beauty. However, food on the train was short with the chief entree being hominy. This 
food was thrown out of the train by many of the enlistees for they would not eat it.

William was called "Pork," a result of his experience in handling meat for his father who was a butcher. Upon arrival at Camp Drew, his first assignment was that of clearing brush and trees from the right-of-way for roads. He then came into the dynamite crew with me at the side camp called Fawn Camp.

Pork recalled with joy our fishing together. While the fish were not large, there never were better tasting fish than the trout we caught. He recalled Harry Kasper, an enlistee from Howells, Nebraska, killing two big salmon at South Umpqua Falls by hitting them on the head with an ax.

At the close of the first six-month enlistment term, Pateidl returned to Nebraska and was discharged. He described his experiences in the Civilian Conservation Corps as "it was just great."

After leaving the CCC, Pork, for the most part, worked in the meat industry including owning his own meat market for many years. When I talked with him, he was found cutting meat at Tilley's Market, Omaha, Nebraska, where he is now employed.

Eric Sinnett did not recall too much about his service in the CCC. He only stayed for the first six-month enrollment period, returning home on October 25 , 1933.

Most of his service was spent at the main Drew Camp. He helped construct telephone lines, roads, a lookout building, and reportedly fought 90 different forest fires. Apparently, his only experience in a side camp was at Devils Knob where he assisted in erecting a lookout.

Eric played much baseball during his service. He recalled one trip that he made with the Company baseball team where they traveled to Roseburg, Coos Bay, Bandon, Port Orford, Gold Beach, Northwestern California, Grants Pass, and back to Drew.

Upon leaving the CCC company and returning to Fremont, Eric was employed in the Maintenance of Way Department of the Union Pacific Railroad, a position he held for 40 years. He was a supervisor in that work, a position from which he is retired. During World War II, he was exempt from military duty due to his work being essential to the war effort. In 1943 he took but two days off from work during the entire year, he said, these being Easter and Christmas Days. He served our nation well.

Morgan A. Werblow spent most of his time in Camp Drew as a mess assistant although he did work some at the side camp at South Umpqua Falls. While at this side camp, he recalled seeing Harry Kasper kill a salmon by hitting it with a shovel. Due to the nature of his kitchen duties, Morgan did not have experiences like those men who were assigned work in the outdoors.

In the fall of 1933 he was transferred with the remaining Company 754 from Camp Drew to Kalvesta, Kansas, where the company constructed a dam. For a number of years water filled the area behind this dam but now it is dry. This second location of Company 754 was about 25 miles northeast of Garden City, Kansas. 
In Kansas, Morgan first became a second cook and later transferred to a position as an earth moving machine operator. At the close of one year's service he was ordered, as were all others, he said, to leave the CCC. During the remainder of his life, he worked at various positions. His memory of the CCC work is that of pleasure.

During World War II, Werblow served in the Seabees. He was overseas in the Pacific Area with his entire service extending for three years and seven months. His final rating was Carpenters Mate, First Class. 


\section{AUTOBI OGRAPHY \\ OF \\ NORMAN A. MYERS}

I was born on August 27, 1911, in Snyder, Nebraska, to George W. and Selma Christine (Lundstrom) Myers. Dad was the principal of the Snyder Public School. Mother had been a school teacher prior to her marriage. My education began in the Snyder School.

Father quit teaching school in the fall of 1917 and about March 1, 1918, our family moved to the old Myers family farm located 7 miles south from Dodge, Nebraska. This farm of 240 acres was excellent. Until 1930, father made a good living for the family on the farm.

It was at the Fairview School, District No. 40, that I graduated from the eighth grade. This was a one-room school with about 45 students and one teacher.

After one year of high school at Dodge, I moved to Fremont, Nebraska, to attend high school. I lived with my grandmother Nancy Ann Myers for three years while attending high school. Following graduation from high school in 1928, I returned to the family farm where I worked until 1933, when the folks lost the farm in the Depression. The prices were so low that, even with good crops, we could not pay back the small amount which had been borrowed. For example, our corn sold for less than 12 cents a bushel.

It was then we moved to 2049 North Maxwel1 Avenue, Fremont, Nebraska, into a small home my parents rented for $\$ 12.00$ a month. This home later was purchased by my sister and it still is in the family. One week after our farm sale, the bank that had the little money our family possessed went bankrupt. With this, my small savings of slightly more than $\$ 100.00$ was lost.

The total lack of money and the lack of employment were the prime reasons for considering an opportunity with the Civilian Conservation Corps. This led to my enrolling in the CCC on May 16, 1933, from which I was eventually discharged about April 1, 1934.

For the next 30 months after release, I worked wherever there was employment. The most steady of these jobs was with the Union Pacific Railroad. About the last of November 1936, I started working at the Fremont, Nebraska, Post Office. After the beginning of World War II, I enlisted in the U.S. Army as a Private and was released as a Captain with more than 2 years spent overseas in the Pacific Theater.

Upon returning to the Post Office in 1946 at Fremont, I took an examination for the position of Post Office Inspector. But it was not until May 1, 1948, that I was promoted to Inspector. I held this position with a New York, New York Domicile until retirement on August 31, 1977. A move was then made back to Fremont, Nebraska. Since that time, I have been busy with the researching and writing about various subjects, chiefly history.

There is no immediate family since I did not marry.

In looking back over my life, the time spent with the CCC organization is one of the best that can be recalled. 
From Burt County, Nebraska

Curtis W. Kerns, James H. Stout and Lewis Cramer of Craig; Delbert D. Gwyn, Alfred L. Lantis, Albert Schlotman and Donald Busse of Decatur; Albert W. Shepard, Burton Clements, George 0. Park, Ben Pueppke and Axel Helgesen of Lyons; Harold W. Davis, Roland C. Hultman, Walter P. Gleeson, Dennis G. Johnson and Bengt A. Backlund of Oakland; and Earl T. Reynolds, Clair Quick, Lloyd Prussia, Charles T. Blair, Conrad C. McClanahan, James C. Bowden, Lloyd Gammel and Paul W. Spant on of Tekamah. When this group left for the CCC induction at Fremont, Nebraska, on May 15, four additional men were sent to take the place or places of any who did not pass the physical examination. These four alternates were Guy VanDeventer of Tekamah, Sherm E1liot of Lyons, Harold Heinlinder of Oakland, and Clay Wedgewood of Decatur.

From Colfax County, Nebraska

Howard Smith of Richland; Joseph Henry of Rogers; Harold Tedford, Lambert Lapour and John Newhaus of Leigh; Jospeh L. Sup, Joseph Karnik, Gabriel D. Loukota and Lad Fayman of Clarkson; Martin Becker, John Nagengast, Jr., Harry Kasper and Hubert P. Behrens of Howells; and Frank Pinker, Robert C. Shonka, George Suic, Robert F. Higgins, James Kramer, Robert Sladek, Paul Sutherland, Gerald Pokorny and Gerald Bryant of Schuyler.

From Cuming County, Nebraska

Roy Romig, Mark Malchow, Leonard Zobel, Alfred Schmidt, Ernst Rickabaugh, Harold Disher, Erven Reher, Frederick Gelster, Bernard Welding, Karl Schmidt, Otto Lammers and Carl Holst of West Point; Lee McKenzie, Andrew Anderson, Floyd Quimby, Edward Schirmer, Julius Tegeler and Vincent Wehrer of Wisner; Lester Brown, Francis Rehberg, Leon Higgins, Joe Kotik and Arlen Lebbs of Beemer; and Edward Anderson, Thomas J. Tighe, William O'Callahan and Guy C. Black of Bancroft.

\section{From Dodge County, Nebraska}

George Fowle, Walter Fritz, Harold Corcoran, Lloyd Wilch, Leonard LeGrand, Norman Crisman, Eugene D. Anderson, Merle McMul1, Ed Knight, Harry Marck, Solomon Garfield, Jr., Richard Fouch, Joseph A. Neilsen, Jerome West, Claude E. Osborn, Leroy Anderson, Walter McGuire, Silva Holcomb, August Horne, Wilmer Peterson, Willard Carmody, Herman J. Hosch, Jr., Russel1 Redding, Eric Sinnett, Victor Sohl, John Eckert, Walter otto, Richard Trannum and Norman Myers of Fremont; Glen Wagoner, Charley Mead and William Pateid1, Jr., of Snyder; Harvey Klintworth, Waldemar H. Maas, J. Murray Hormel and Arthur E. Joens of Scribner; Ray H. Baker, Elwyn G. Moore, Delbert Hiveley and Clarence Schultz of Hooper; Dale McDuffee and Willis Borcher of Uehling; Jesse Kingry of Ames; Morgan A. Werblow, Marvin Detlefsen, Paul L. Swan and Donald Kern of North Bend; and Nicholas Laudenklas and Raymond Ludden of Dodge. Two of the men listed above failed their physical examinations, but their names were not identified. Two of the alternates were substituted for these men: Orville Wright and another alternate member who was not identified. 
From Saunders County, Nebraska

Otto Fox, John Kirchman, Ray Schwartz, Verne Story, Jerome Barnel1, Cecil Flowerday, Elmer F. Passo, Robert R. Alden and Henry Anderson of Wahoo; Floyd Olson and Ray Wiysal of Malmo; James B. Scanlon of Ceresco; William McKeghan, Harry Peterson and Robert Bahde of Cedar Bluffs; Harold F. Lang, Thomas Plymate and Eugene C. Sullivan of Mead; William C. Burr, Gerald Vandeman, Rosc oe Whitehead, Archie Hightshoe, Frank A. Wills and George Pike of Ashland; Willard Olson, Wilbur Geib, Clarence E. Marshall, Lawrence Linch, Peter L. Rohman and Hollice Chever of Valparaiso; Walter Luhnow of Ithaca; Randall Vosler of Wann; Lloyd Klotz of Swedeburg; Harold Miller of Leshara; Victor Pabian of Morse Bluff; Frank Pabian of Prague; and LeRoy Eggers and Carl Page of Yutan.

\section{From Butler County, Nebraska}

While the seventh CCC sector of Nebraska did not include Butler County, a number of men from this county did come into Company 754. The available listings did not include their local city of residence. Fred Abern, Leroy Ransom, Clemence Michalek, Richard Bolton, Art Hageman, J. Dale Buckley, Edwin McDonald, Otis Kilgore, Warren Muntz, Jerome Smith, Joe L. Malina, John Delaney, Gabril Klein, Russell Kinman, Joseph Kremlacek, Fred J. Coufal, Joe Sabata, Ernest Korinek, Frank Sima, Harold Lauer, Charles Doty, Edward Gregory, Floyd Lenenicka, James Raddock, Frank Benedict, Leonard Styer, Hubert Kaminski and James Svoboda.

The above information was taken from The Burt County Herald, Tekamah, Nebraska; The Schuyler Sun, Schuyler, Nebraska; The Fremont Evening Tribune, Fremont, Nebraska; The West Point Republican, West Point, Nebraska; The Wahoo Wasp, Wahoo, Nebraska; and The Peoples Banner and The Butler County Press, David City, Nebraska. 
1

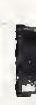

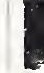



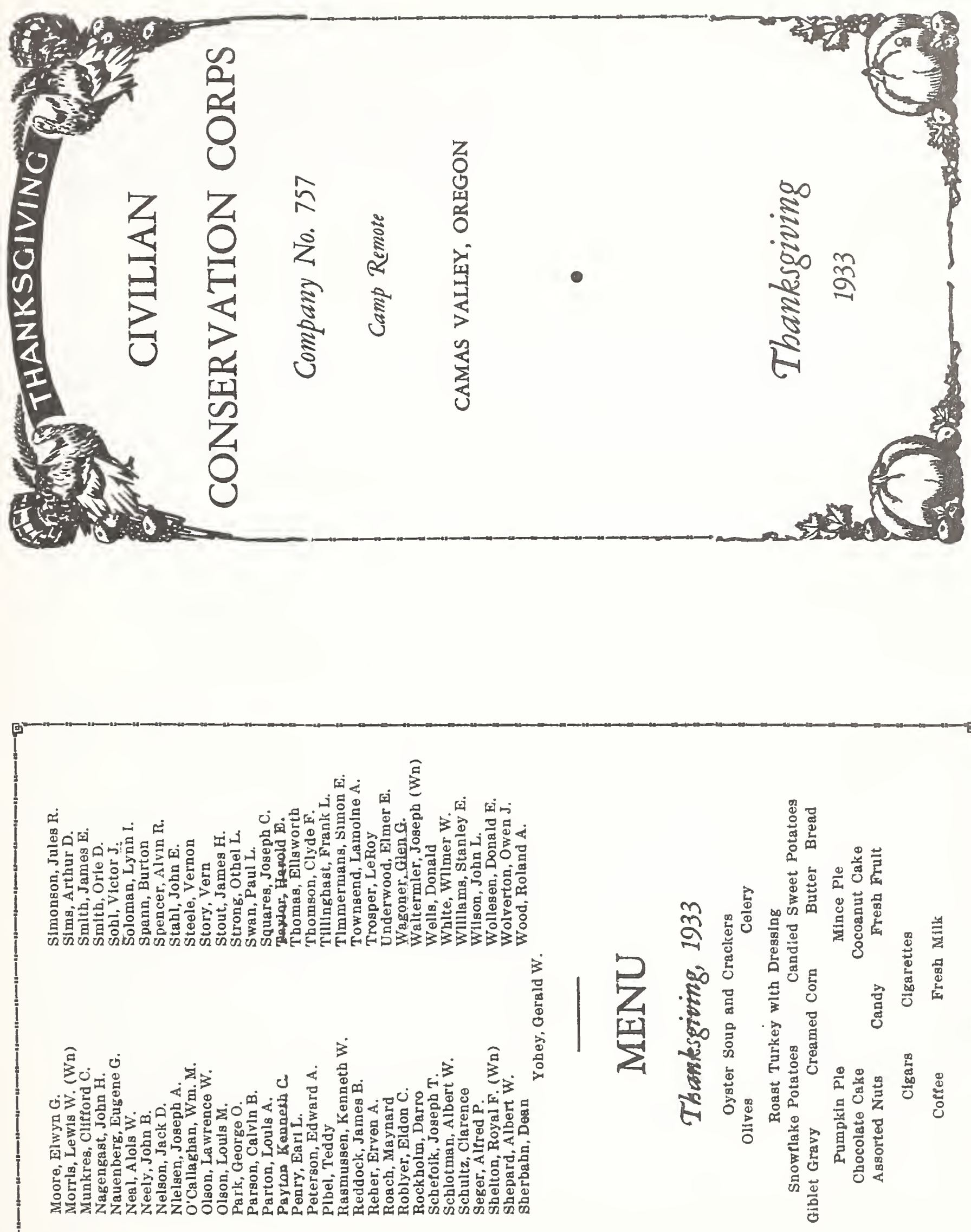


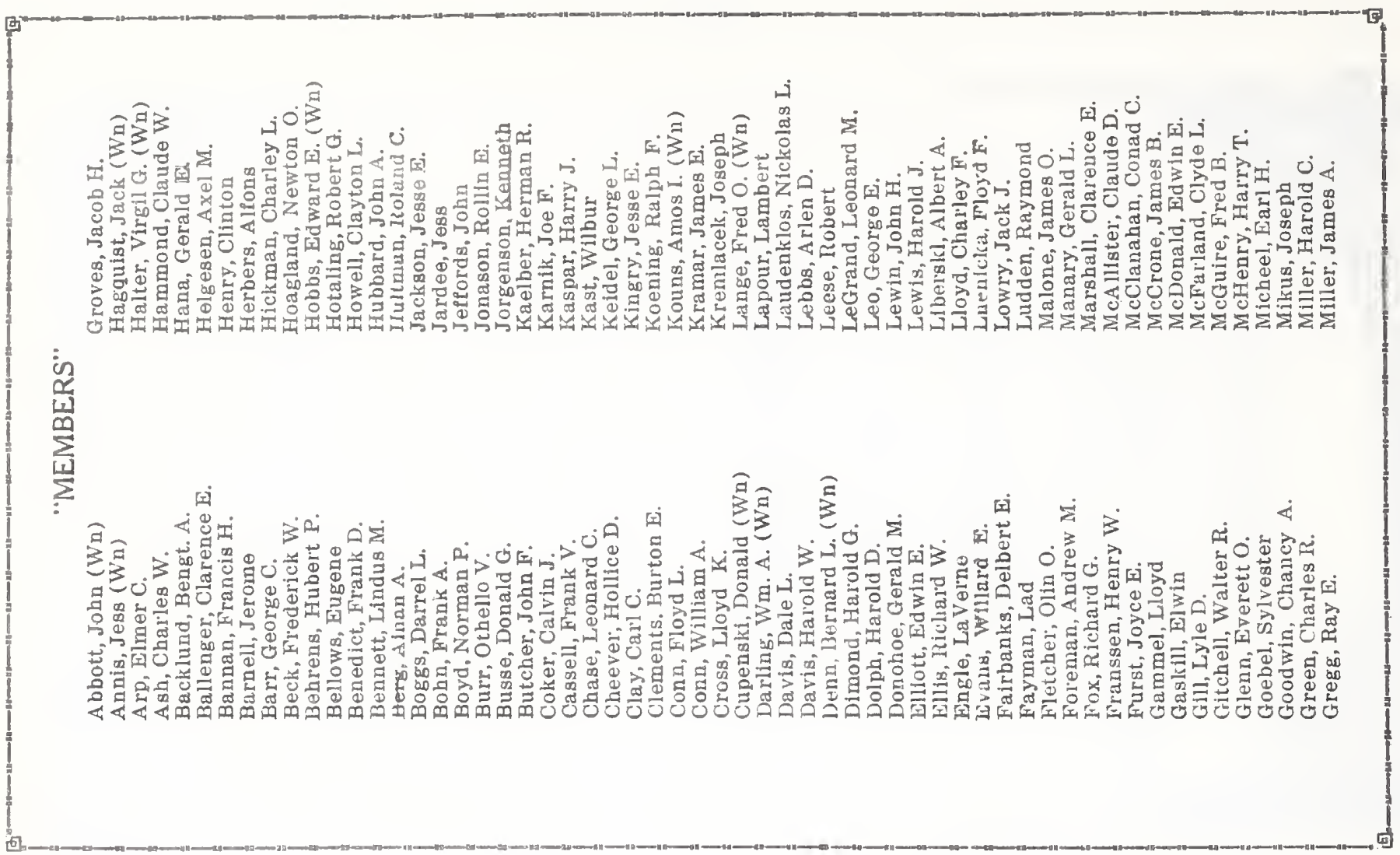

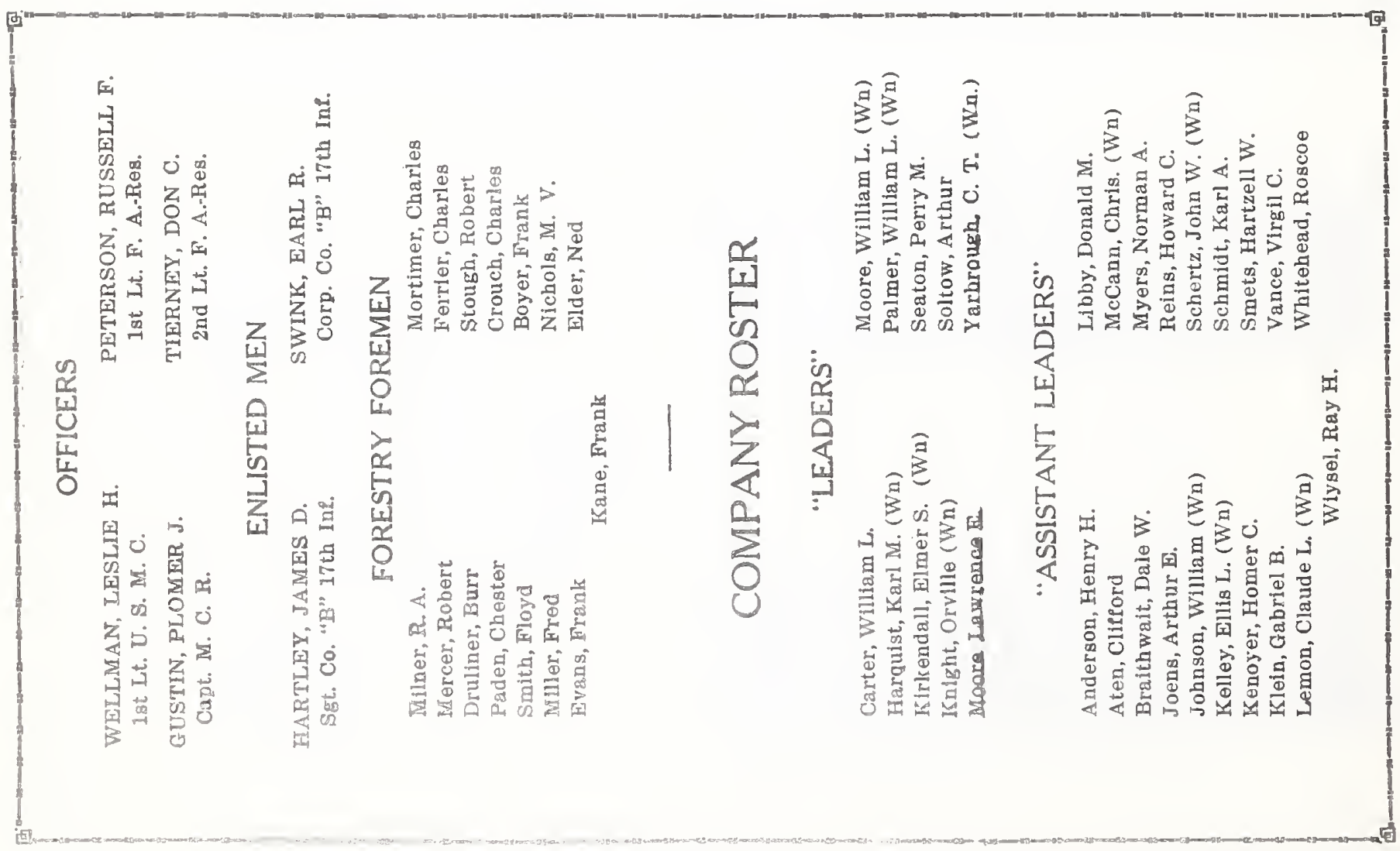



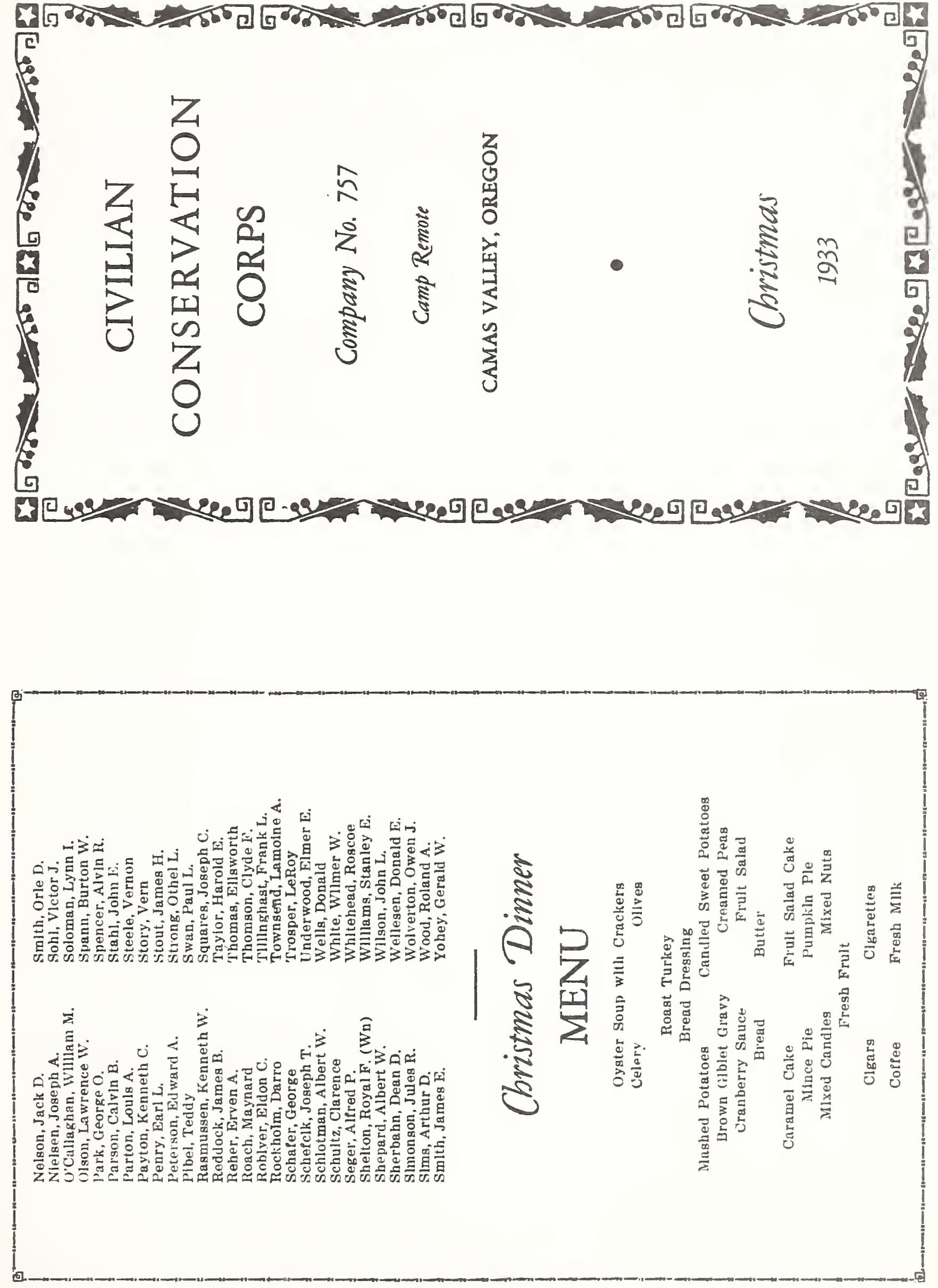

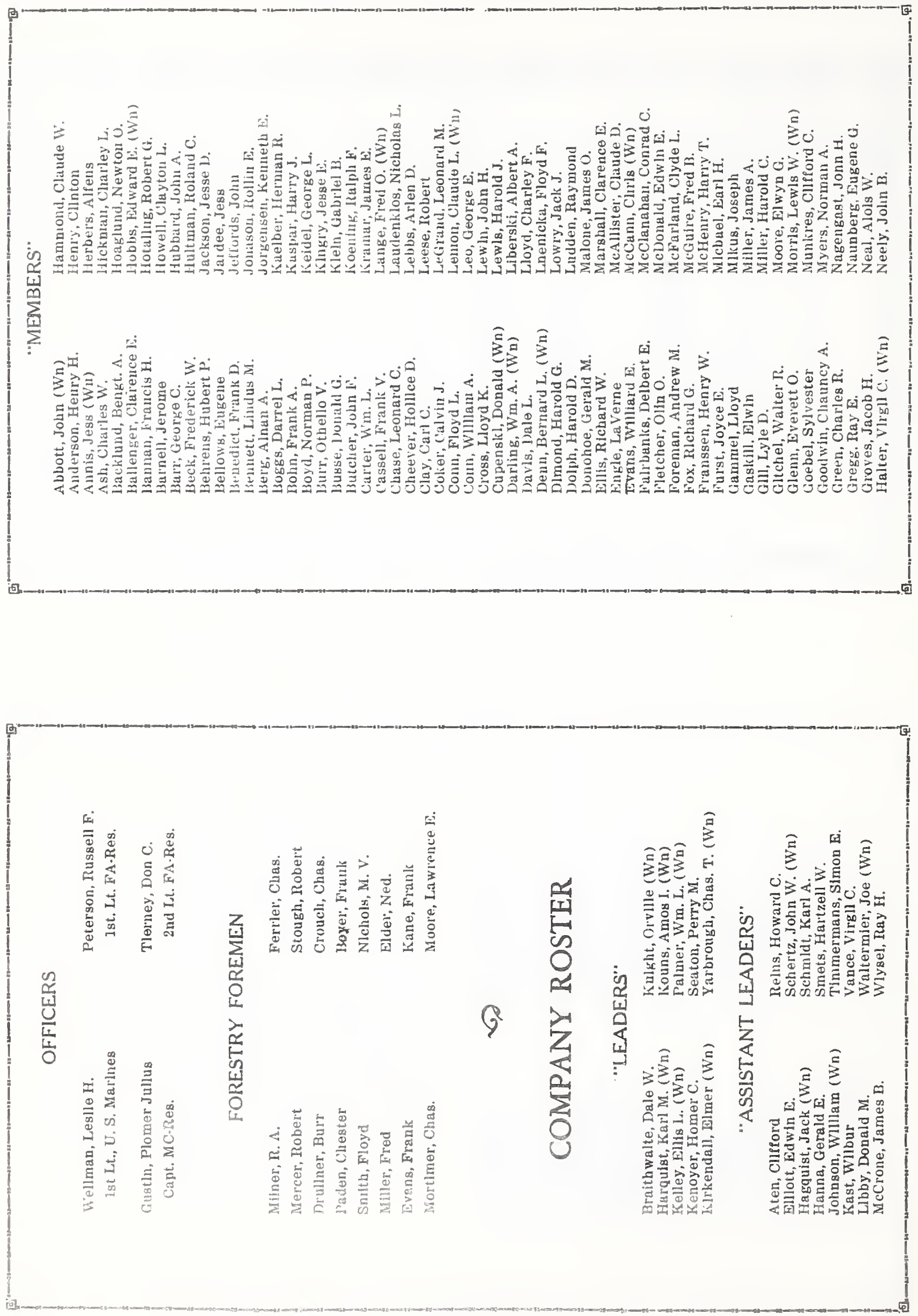
PHOTOGRAPH SECTION*

*The following photographs were by or for Norman Myers during his time at CCC Camps Drew and Remote. Additional photographs have been loaned by other CCC enrollees at these camps. Unless otherwise credited, the photos are from the Myers collection. The photographs, although undated, correspond chronologically to Norman Myers letters, beginning around May 20, 1933, and ending around March 30, 1934, unless otherwise noted. 



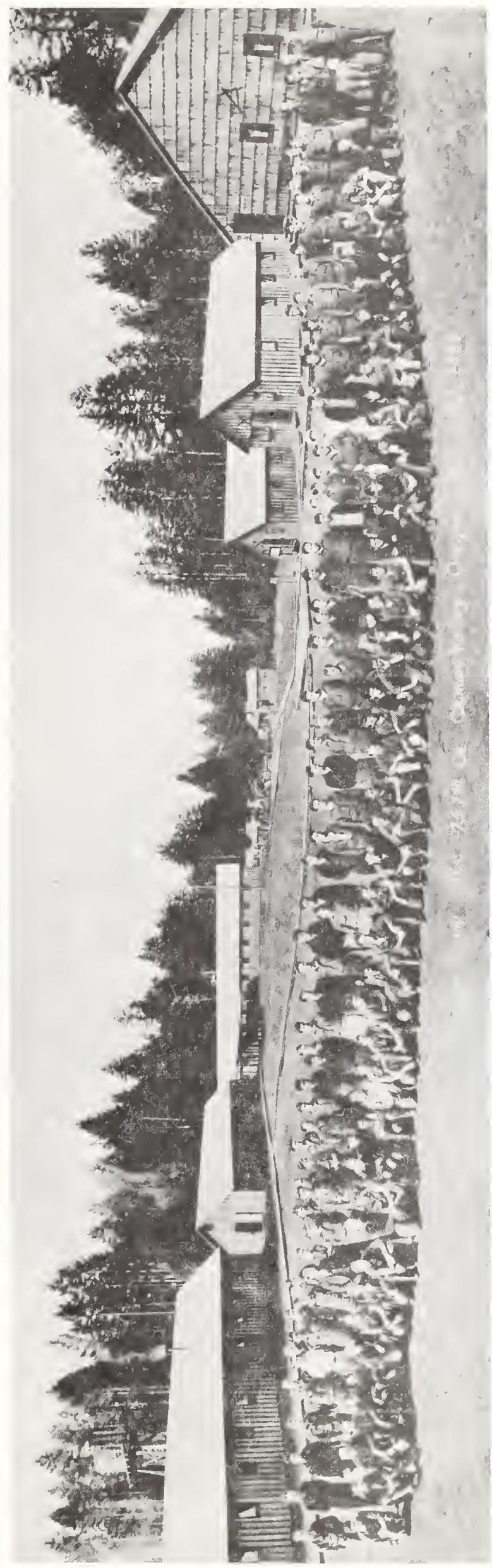

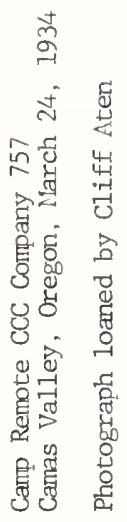




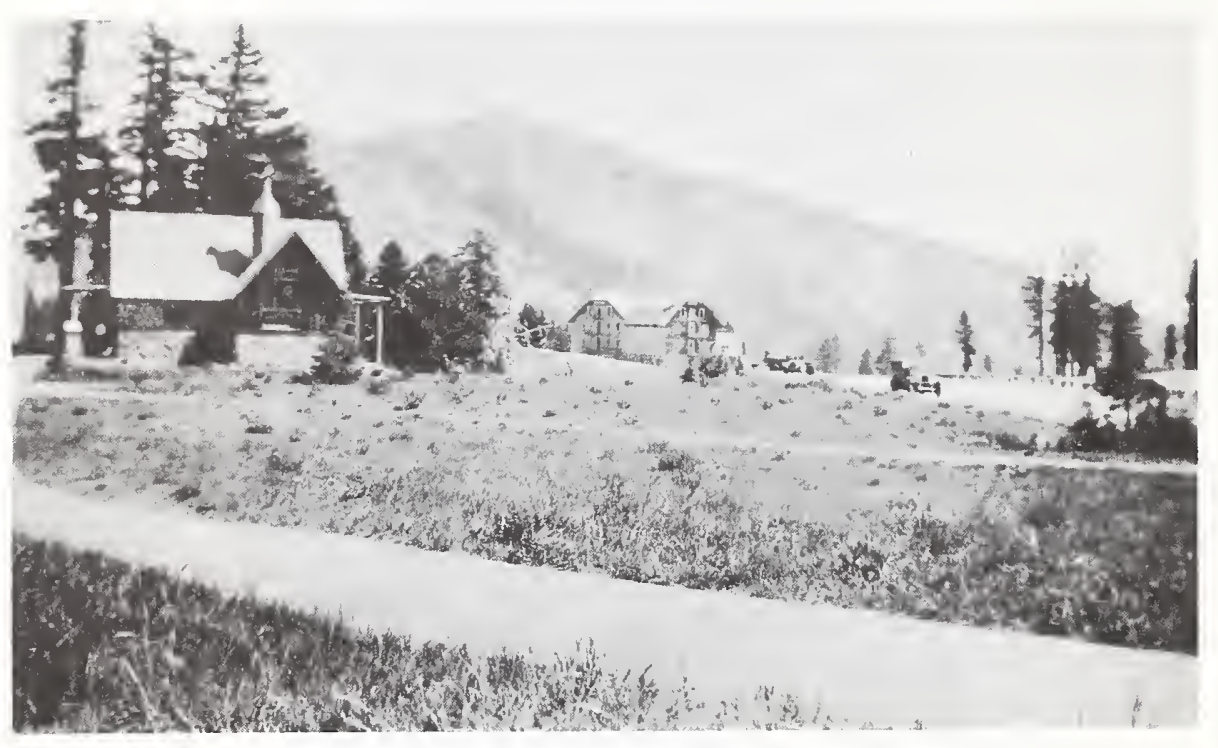

Crater Lake National Park showing the lodge in the background.

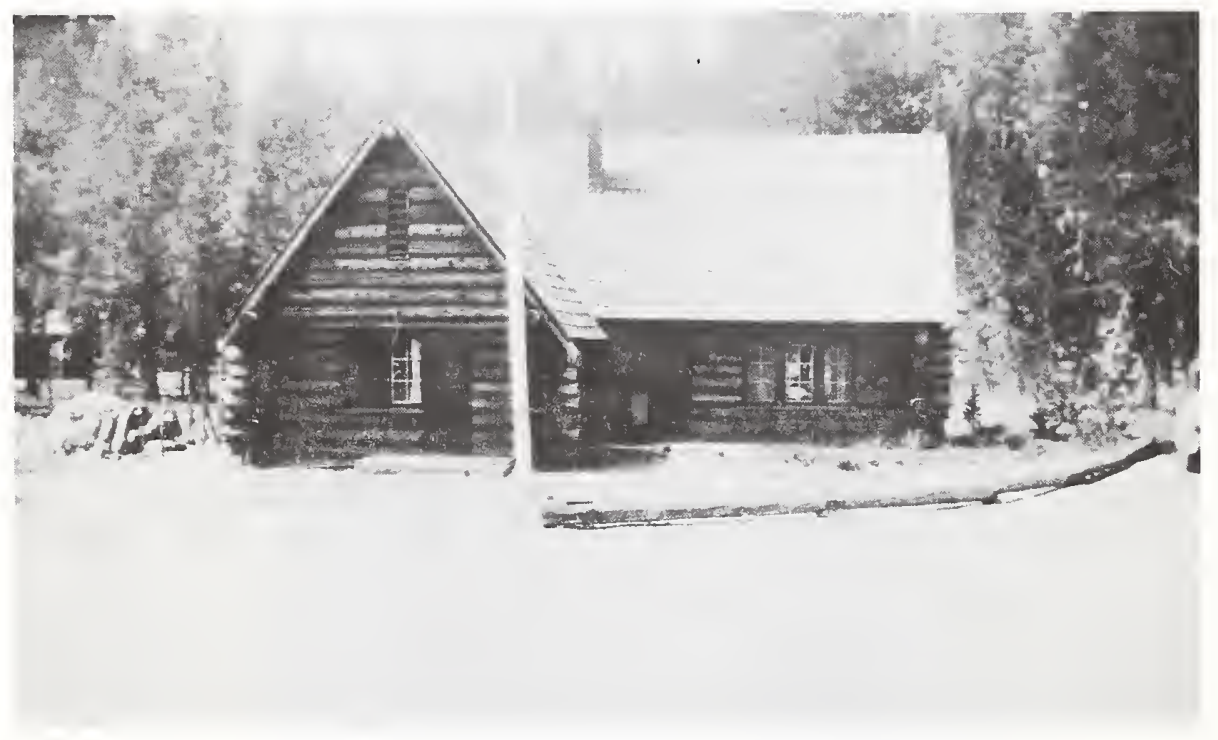

Residence of the Superintendent for the Crater Lake National Park. 


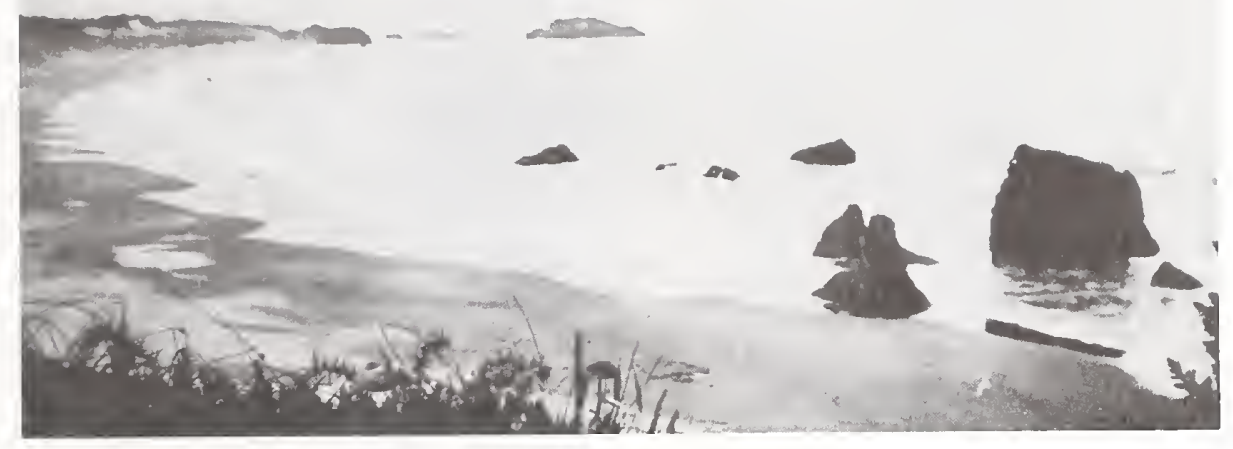

Oregon Coast near Bandon while on a Camp Drew CCC enrollee trip to the Pacific Ocean.

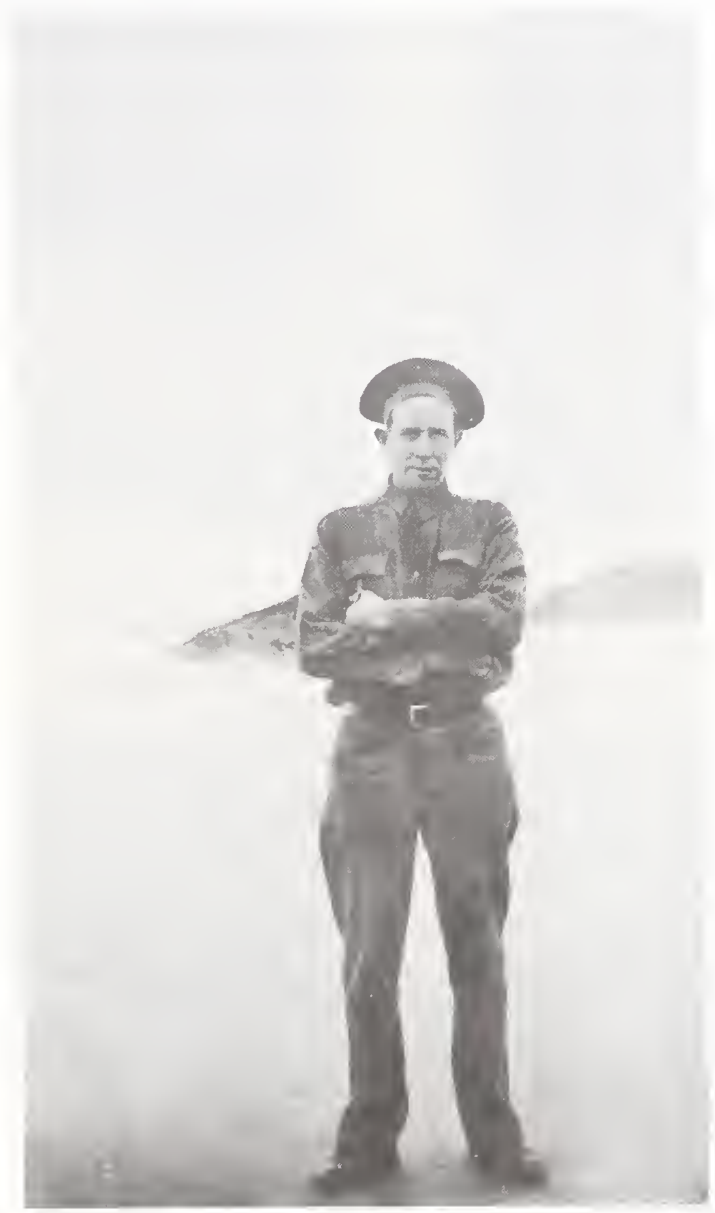

Morgan A. Werblow from Fremont, Nebraska, while on CCC trip to Oregon Coast. 


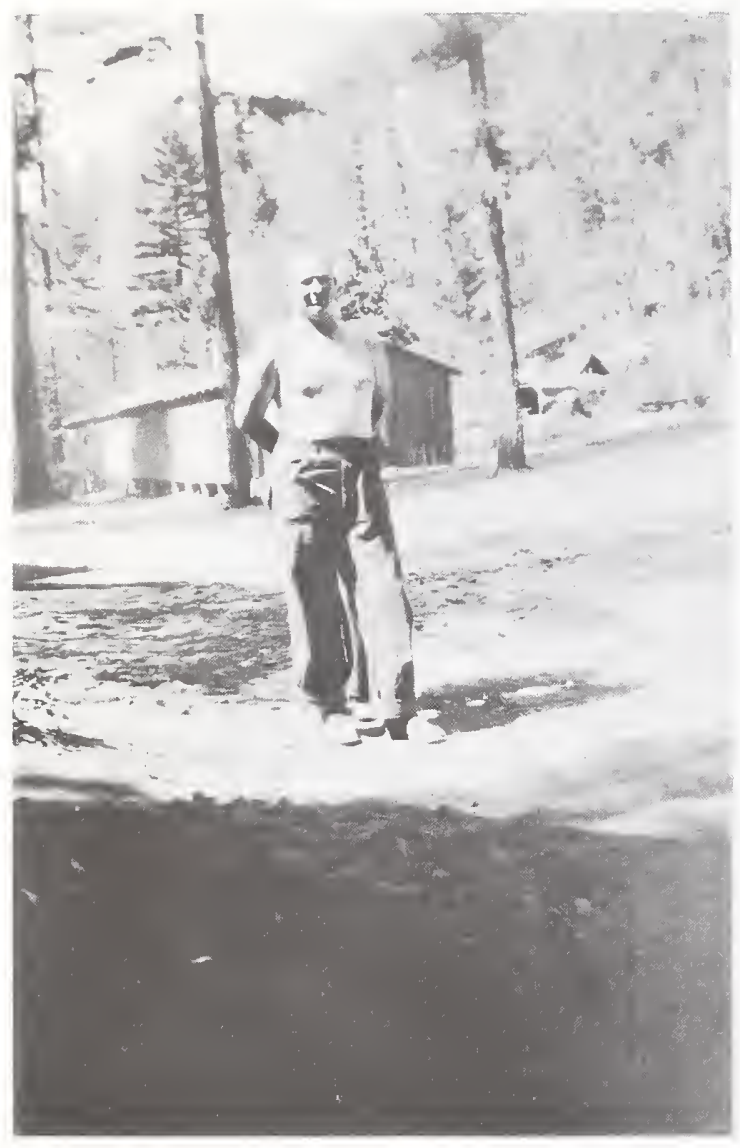

Alfred L. Lantis from Decatur, Nebraska. Canp Drew mess hall in background.

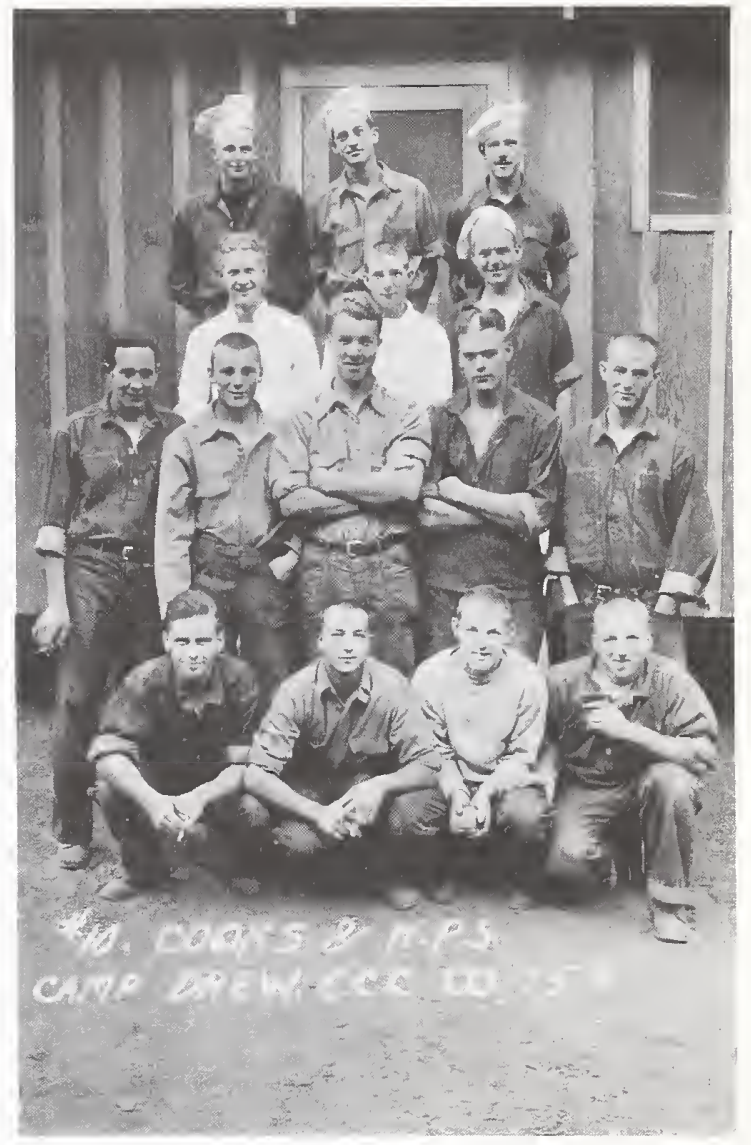

Cooks and kitchen police (KP's) at Camp Drew 


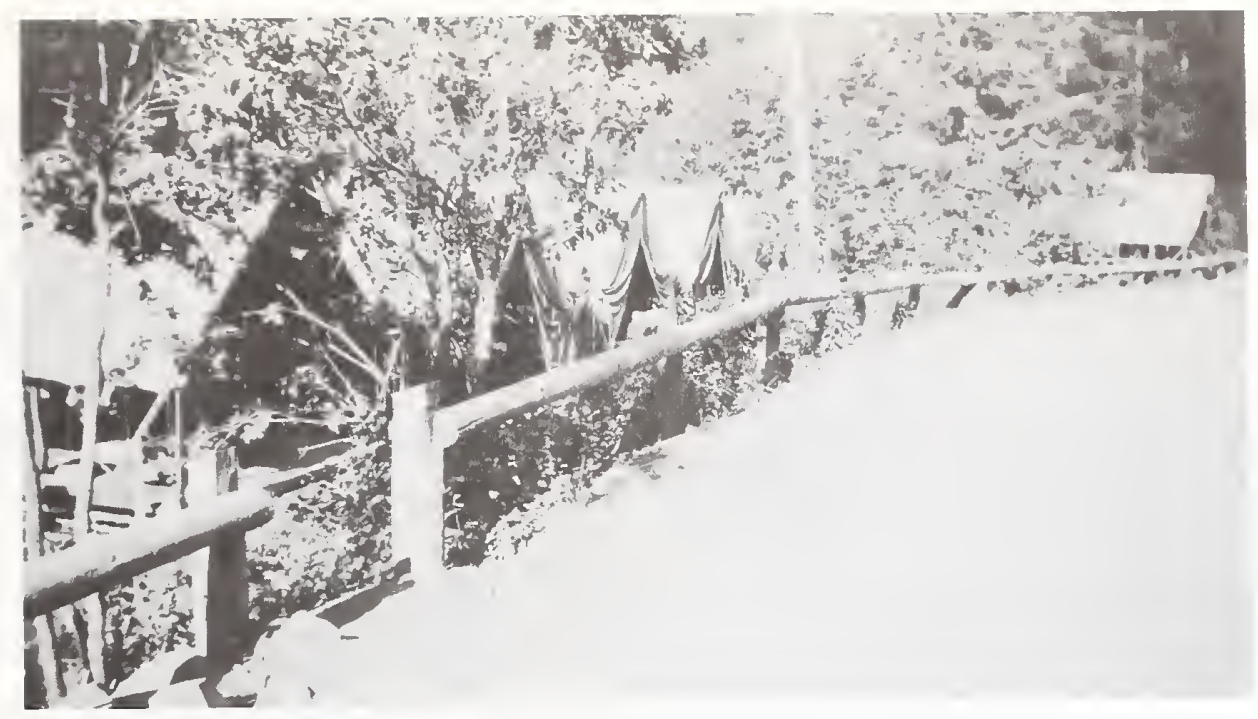

Drew Camp. Drew Camp.

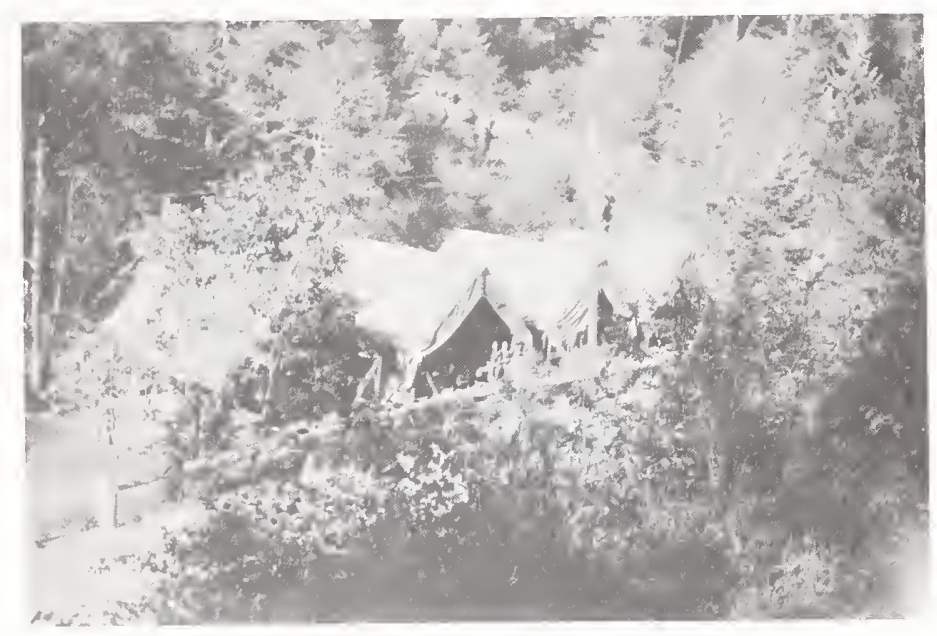

Drew Camp showing tents

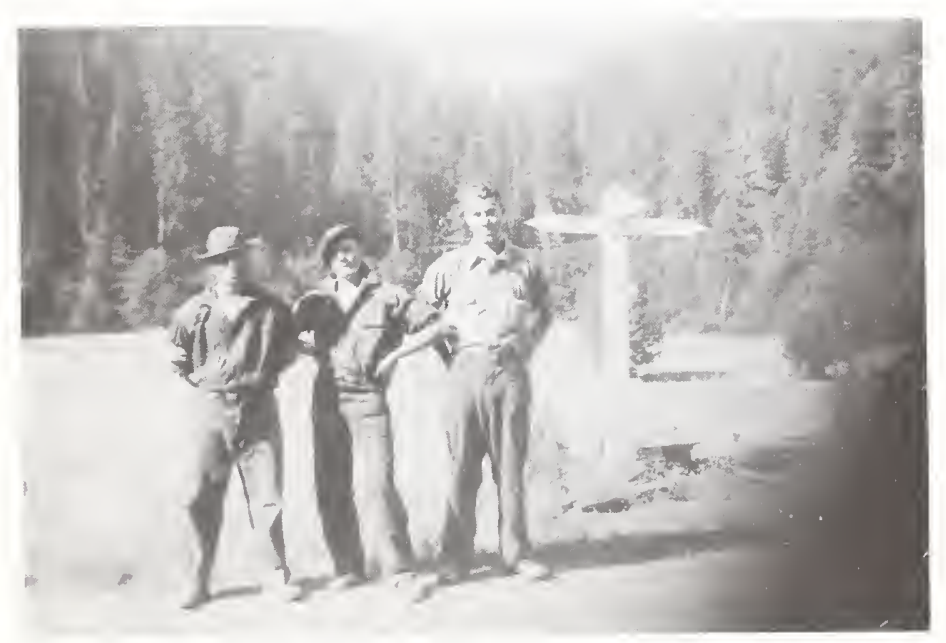

CCC Enrollees at Camp Drew. John Eckhart in center. 


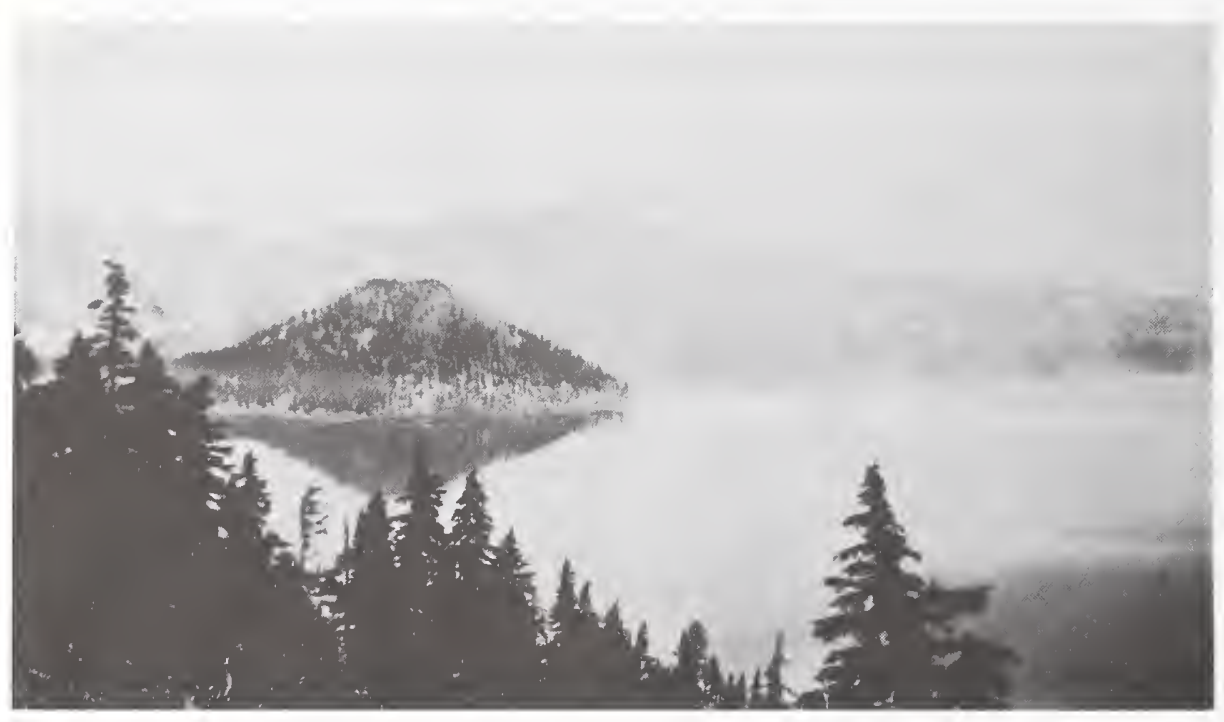

Crater Lake with Wizard Island while on CCC enrollee trip from Camp Drew.

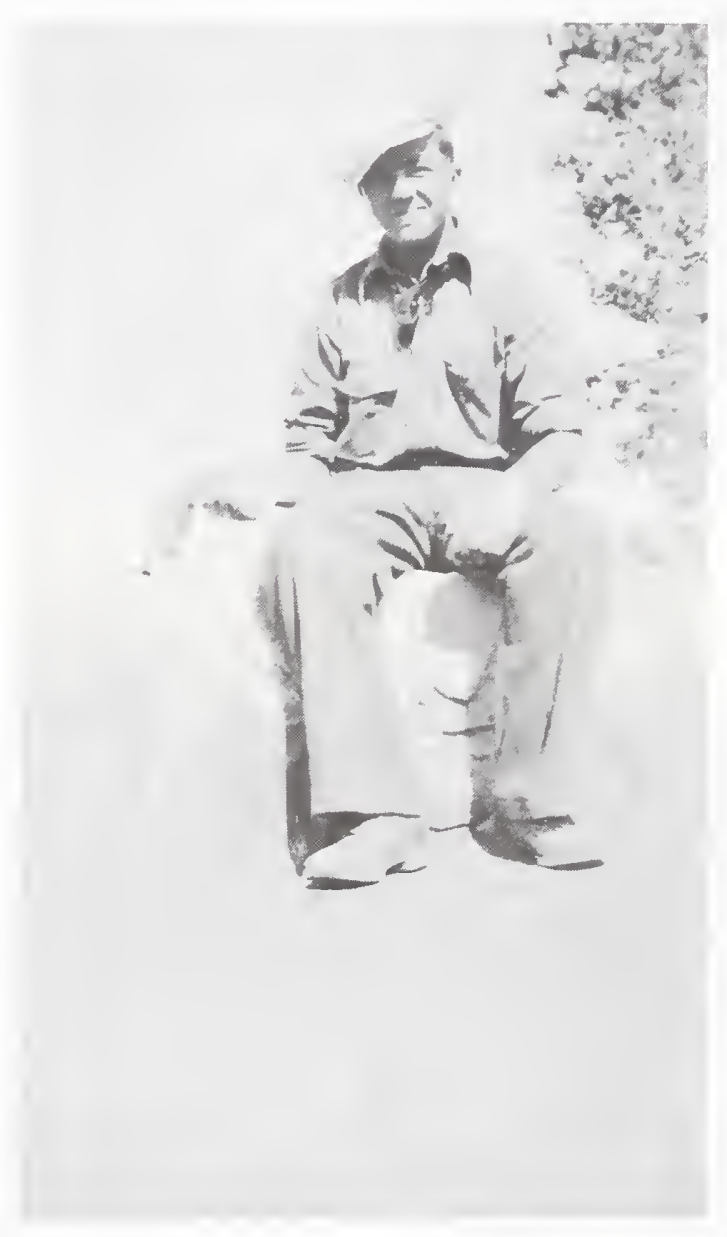

Fedding a chipmnk at Crater Lake National Park. 

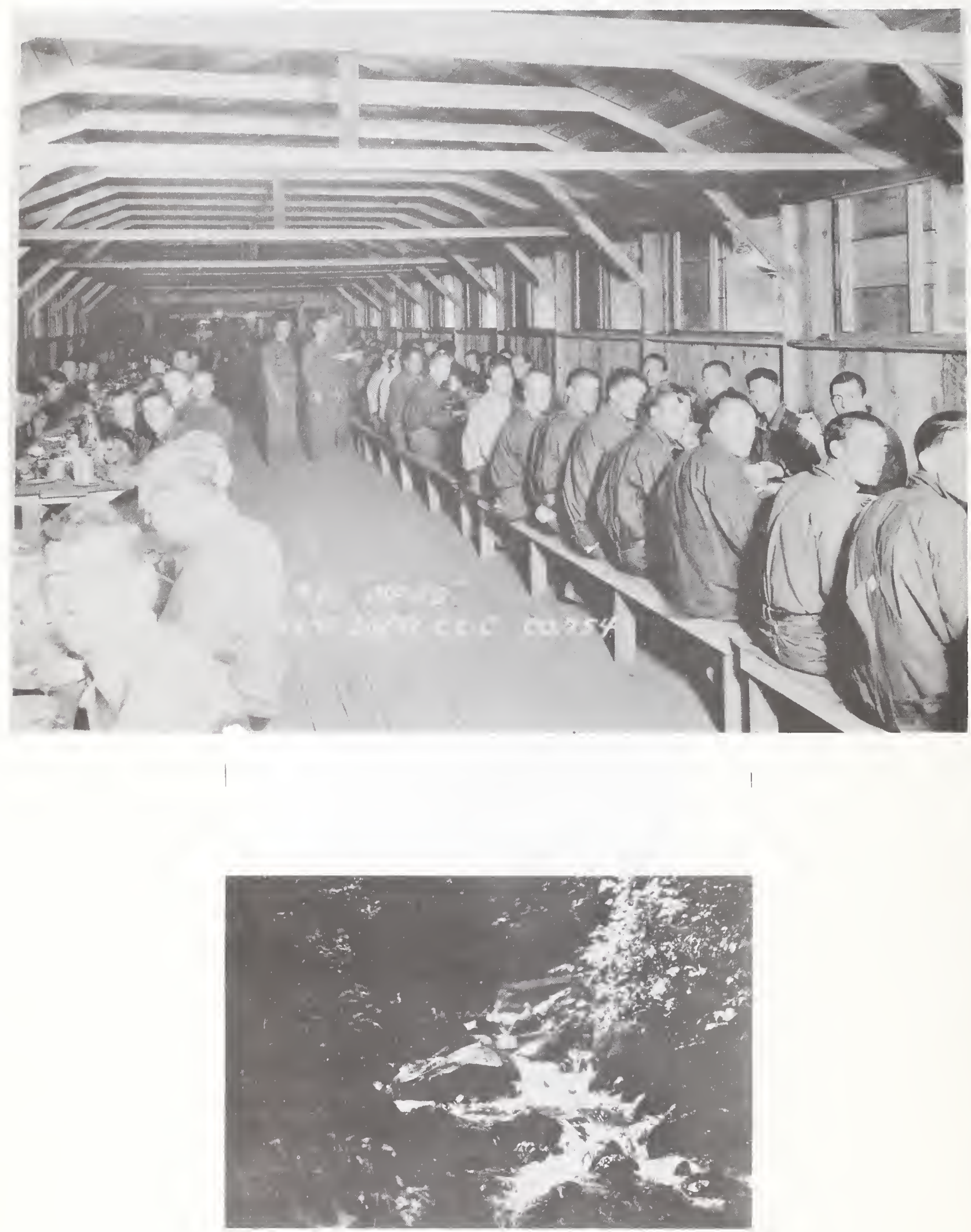

A picture of Elk Creek, typical in that water is rushing past rocks. 


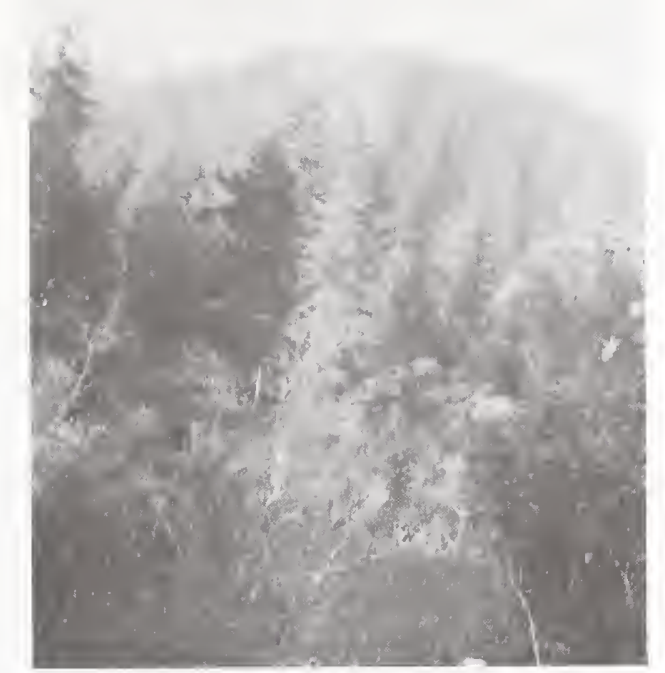

This picture was taken after crossing Elk Creek from the camp and climbing part way up the mountain.

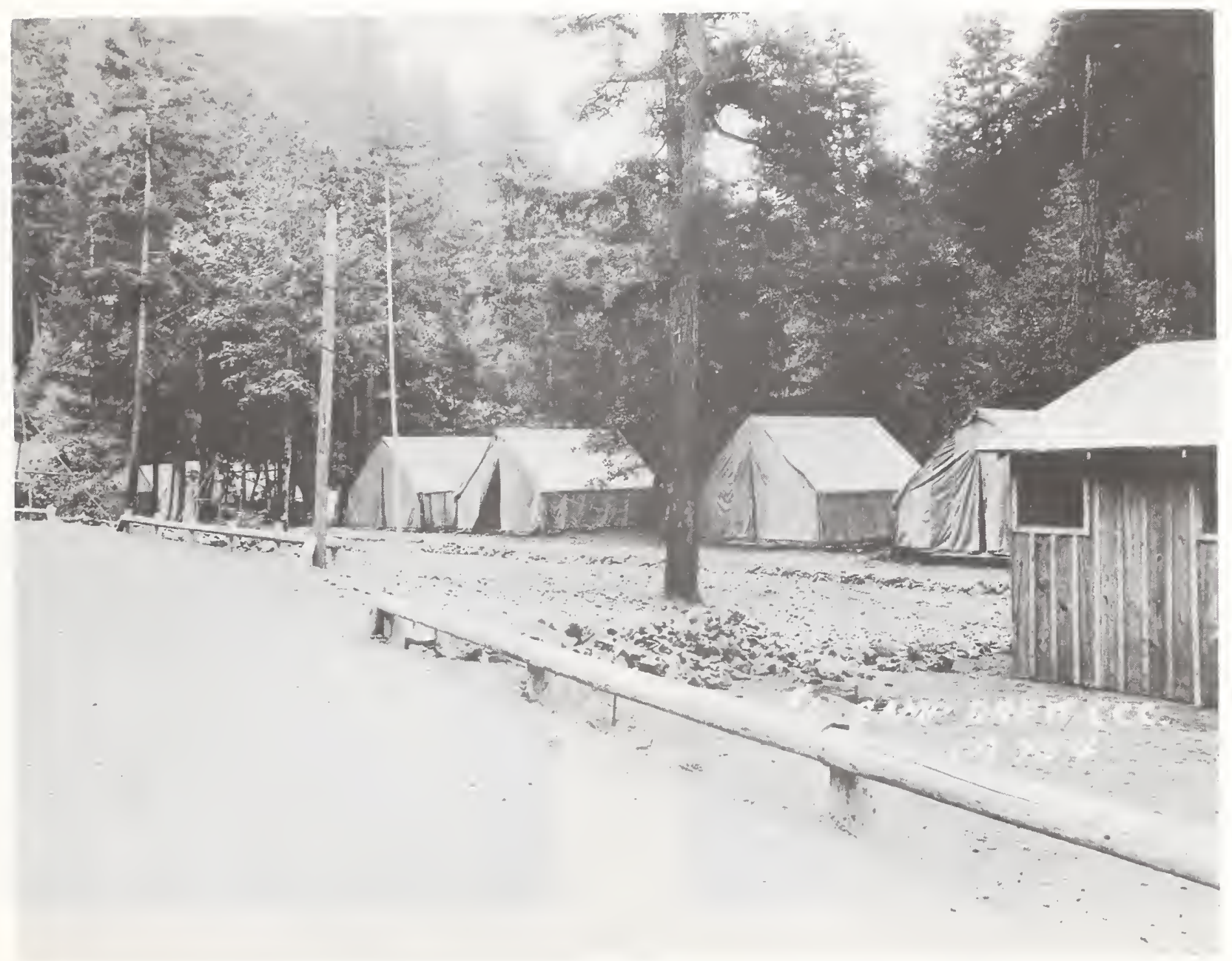




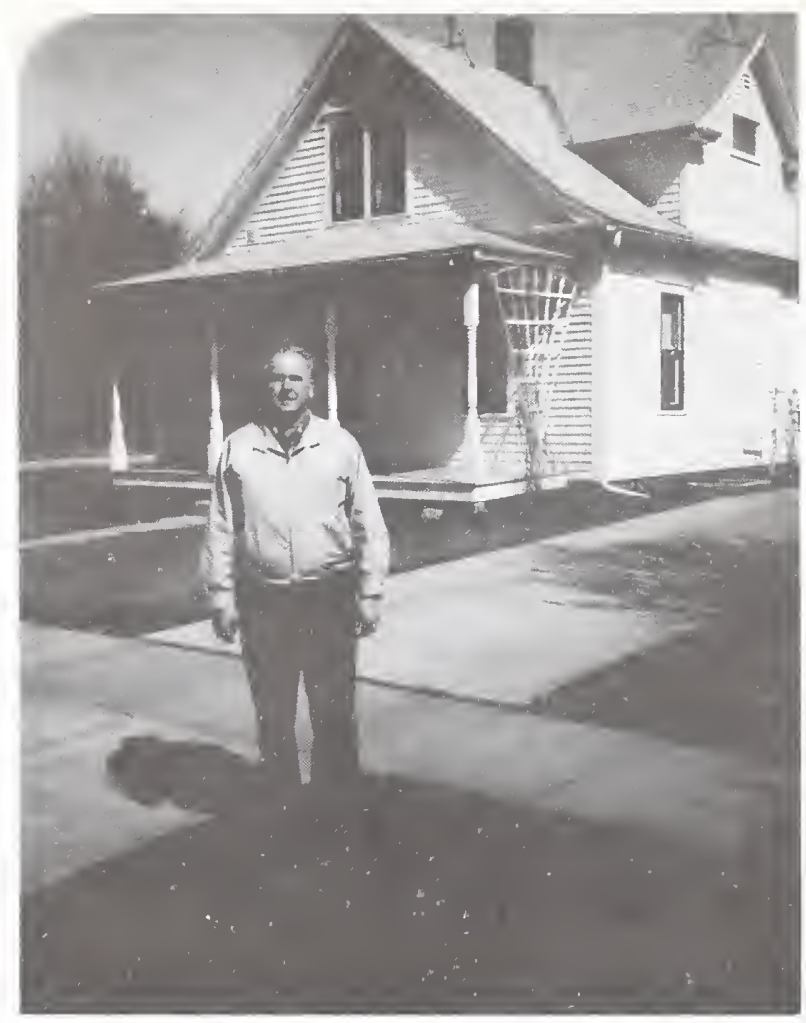

Norman A. Myers in front of parents home in Fremont, Nebraska. March 1983.

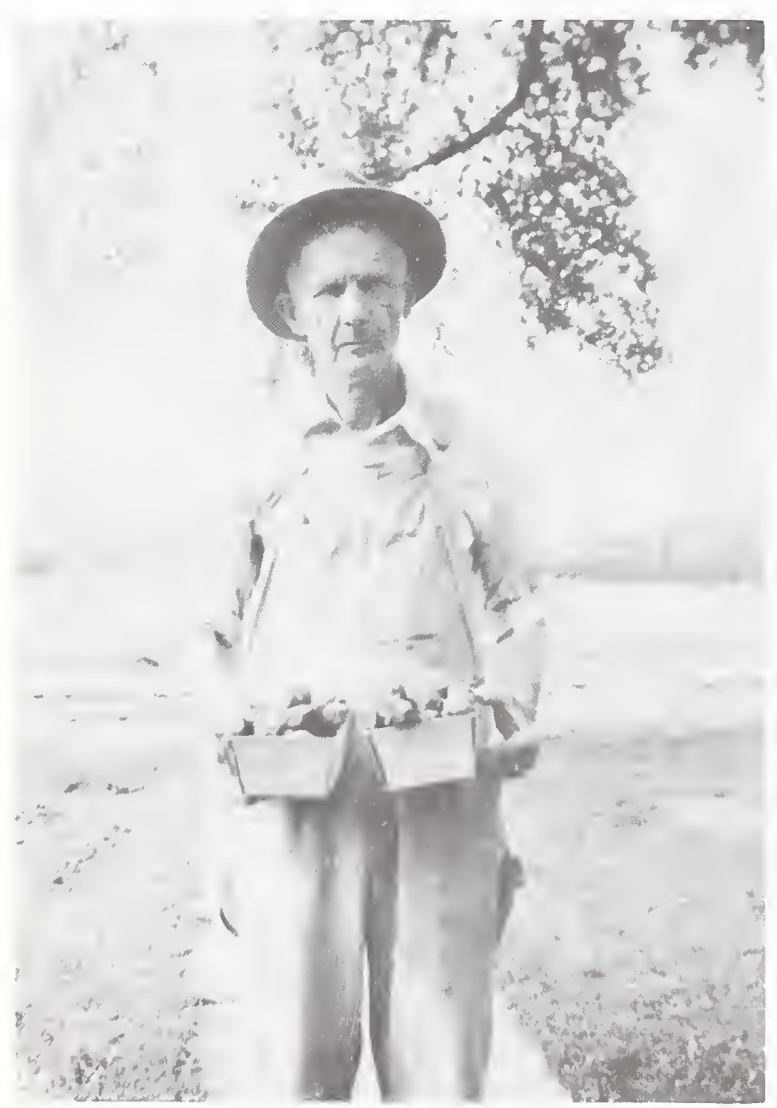

Dad with two quart containers of his strawberries.

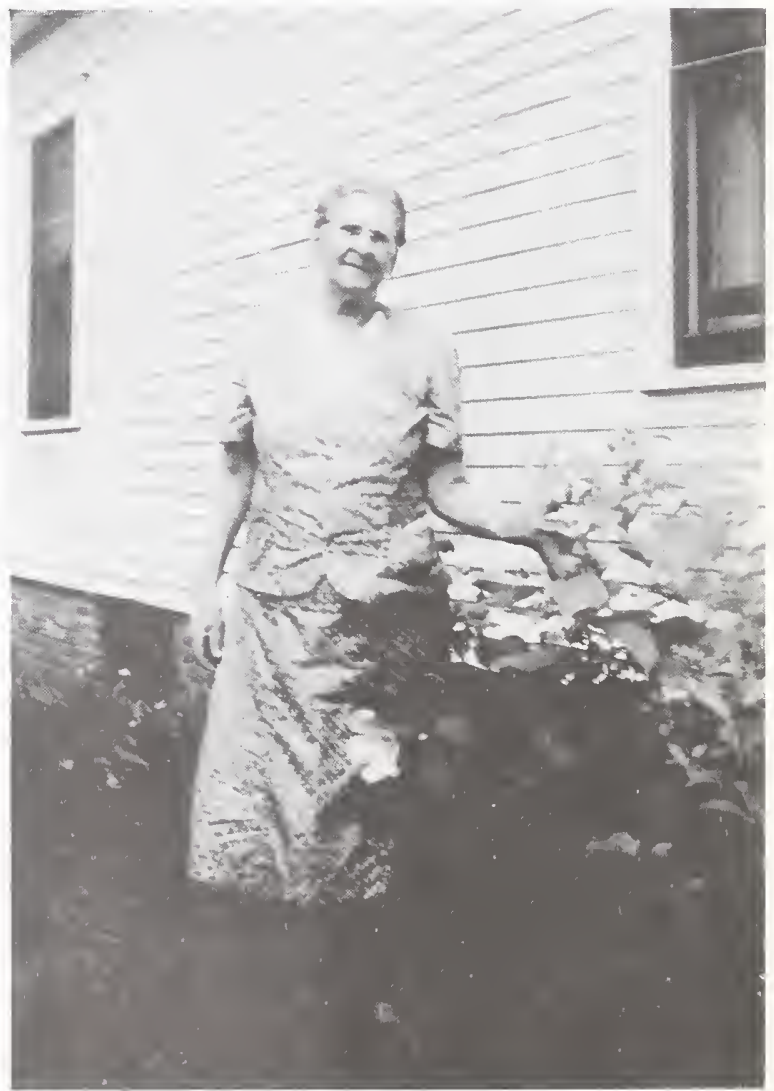

Mother with one of her flowers beside the home. 


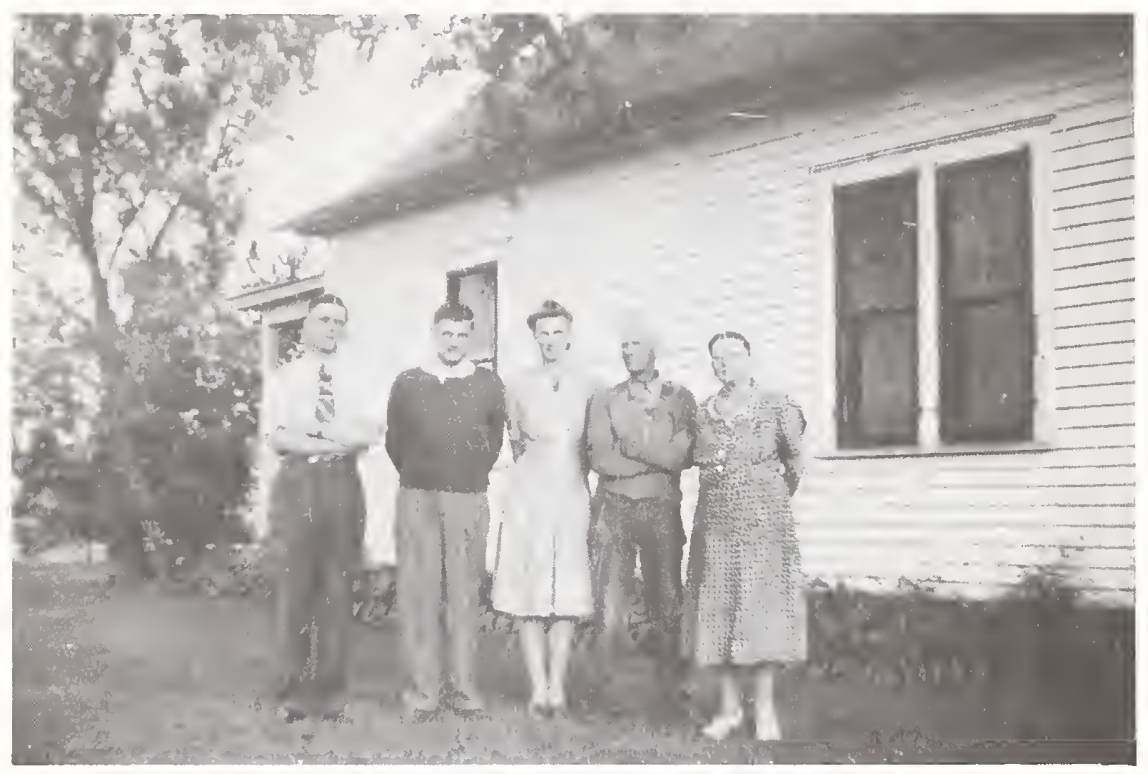

Our family on the day I left to go overseas in World War II. Norman, Enerson, Ruth, Dad and Mother.

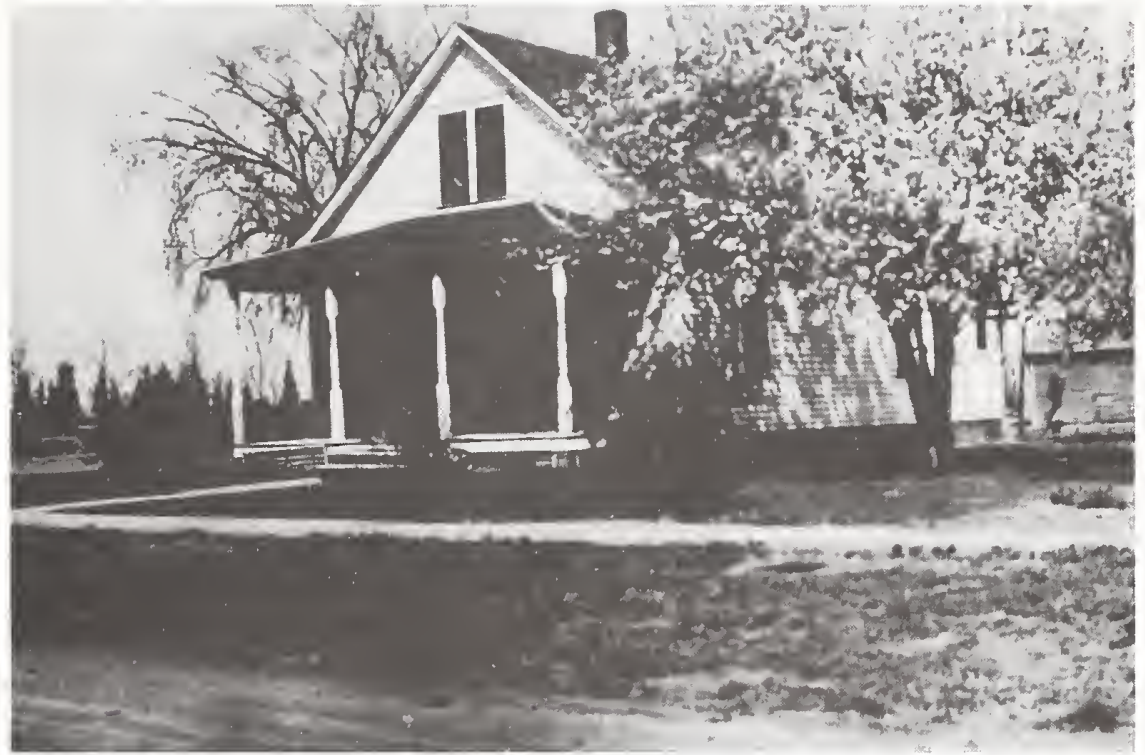

Our home at 2049 North Maxwell Avenue, Fremont, Nebraska. 


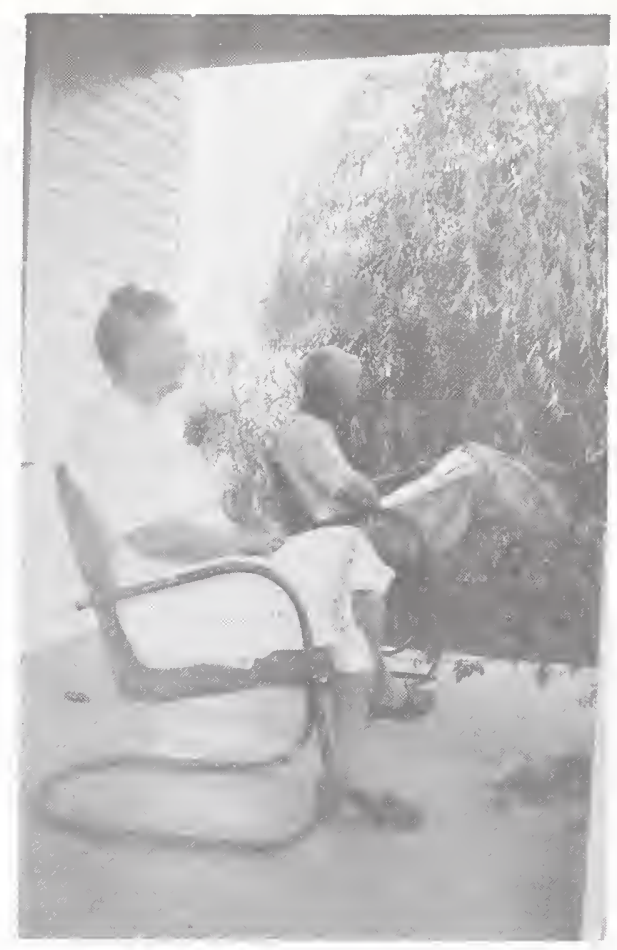

George W. and Selma Myers sitting on the front porch of our home in Fremont Nebraska.

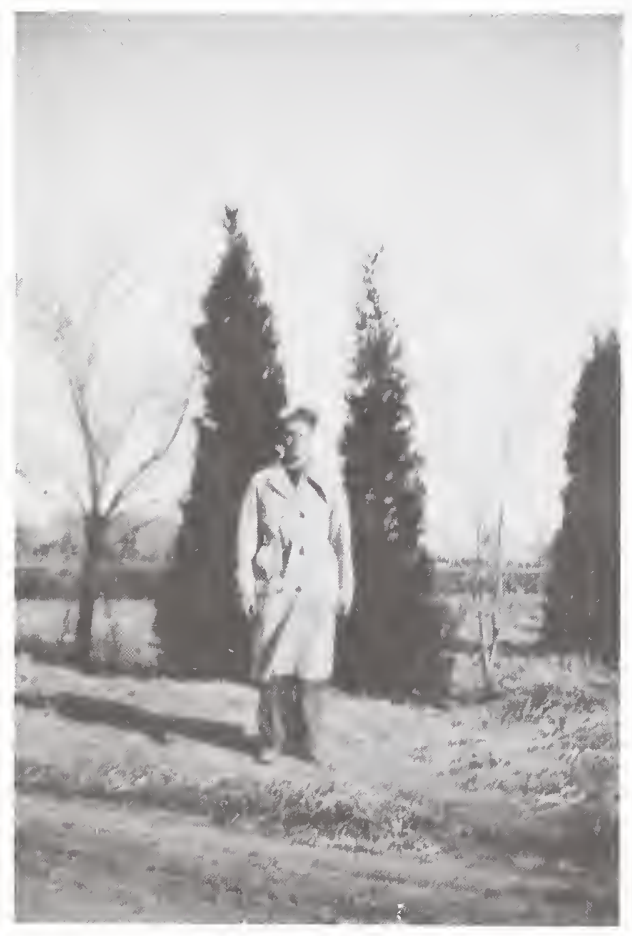

Photograph of me upon arrival at home in Fremont, Nebraska. The trench coats they issued to us were probably the finest I have ever owned.

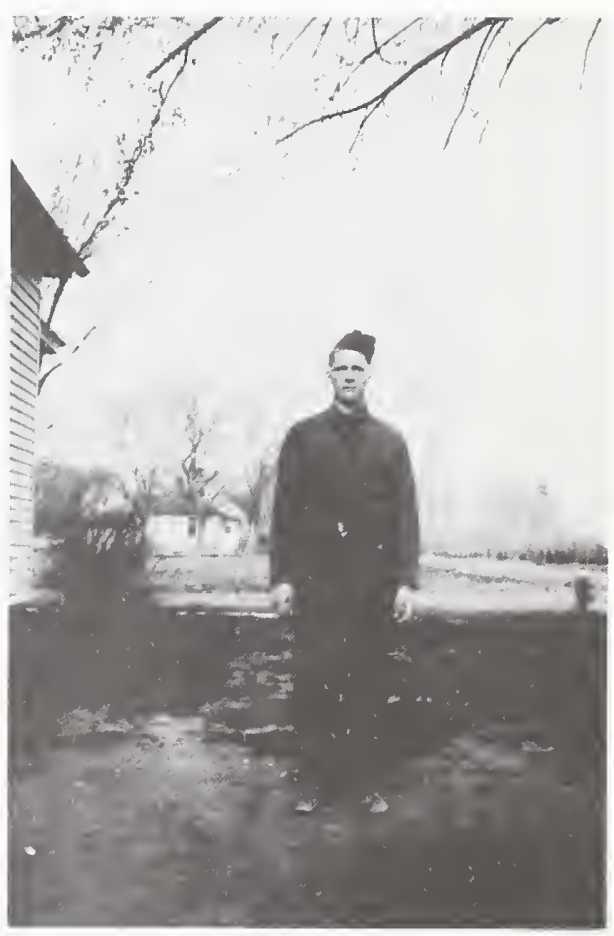

At home wearing my winter uniform. 


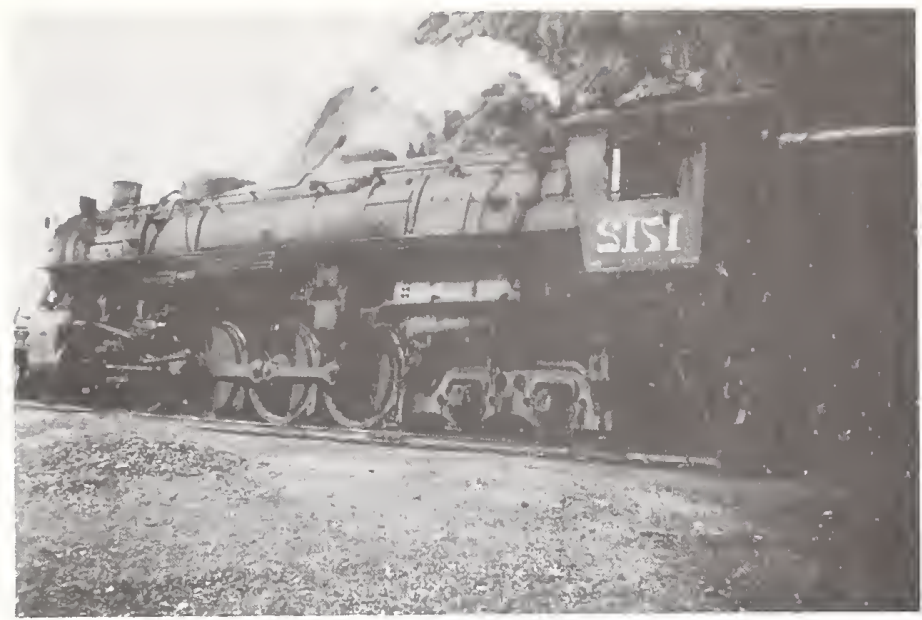

The Denver and Rio Grande Western Railroad took our train over at Ogden, Utah on the way home. This locomotive was photographed at Thistle, Utah, a station west from Soldier Sumit while we prepared to climb the grade.

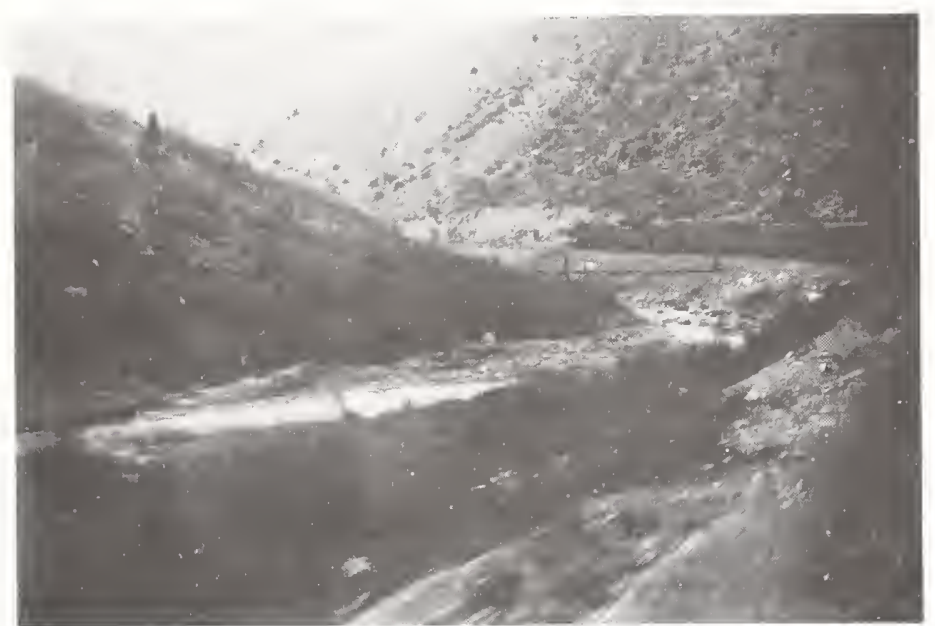

Our train enroute home in a Utah canyon. At Pueblo, Colorado, the Denver and Rio Grande Western Railroad turned the train over to the Missouri Pacific for Omaha, Nebraska, by was of Kansas City, Missouri. We left the train at the Fort Crook station.

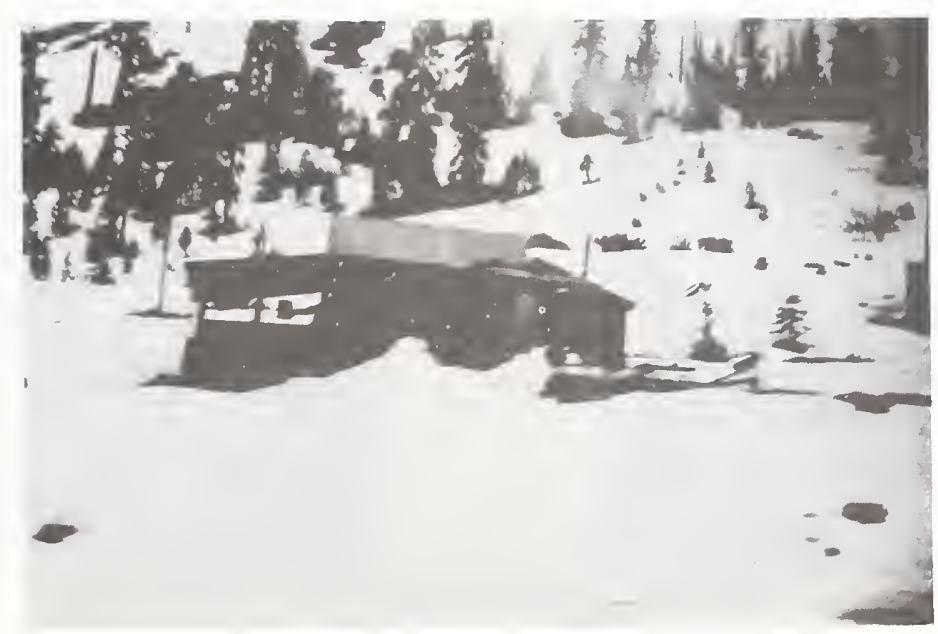

Deep snow in the Donner Pass Area of California on our way home on the Southern Pacific Rail Road. 


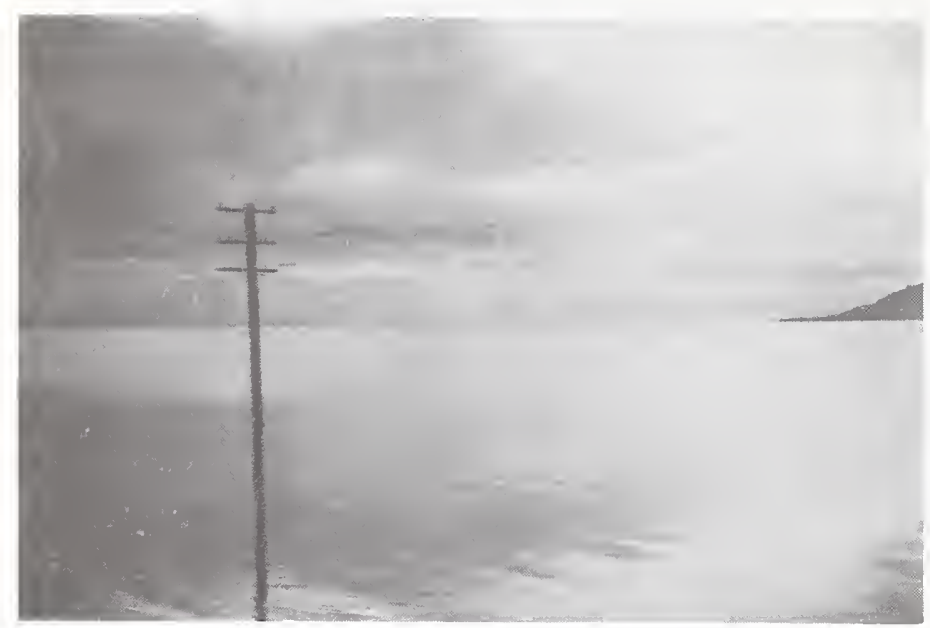

Great Salt Lake as seen from the Souther Padific train on our way home.

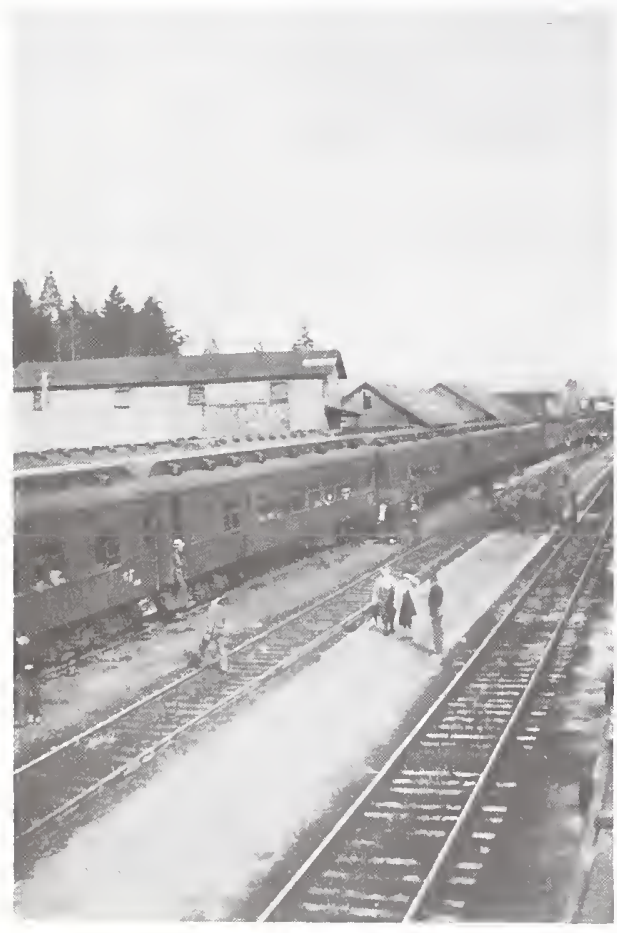

We went to Eugene during the late spring of 1934 for entraining back to Nebraska. This view is of the train while we loaded.

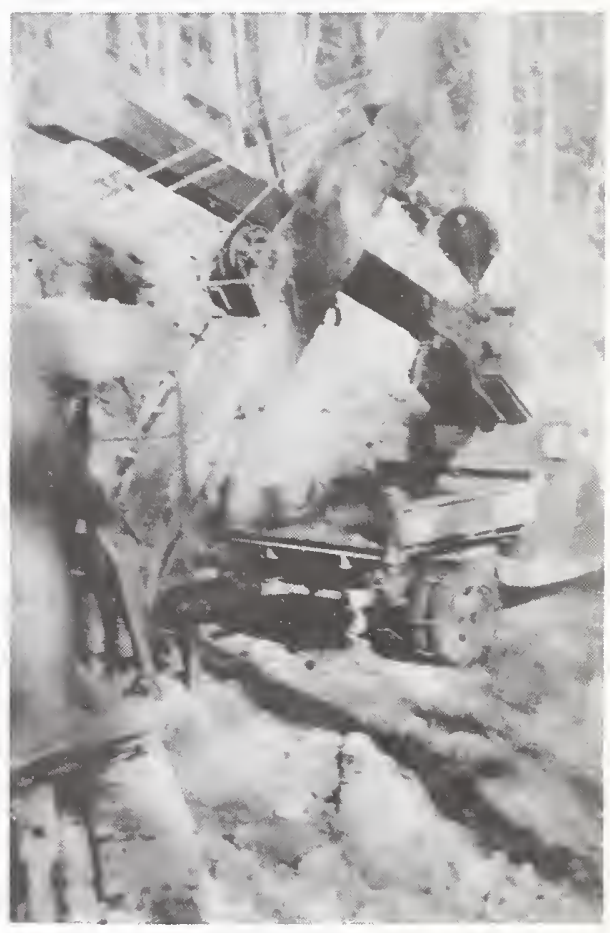

The gas shovel we used working from the Buck Springs Side Camp. The stone quarry was near the camp on the road toward Camp Remote. 


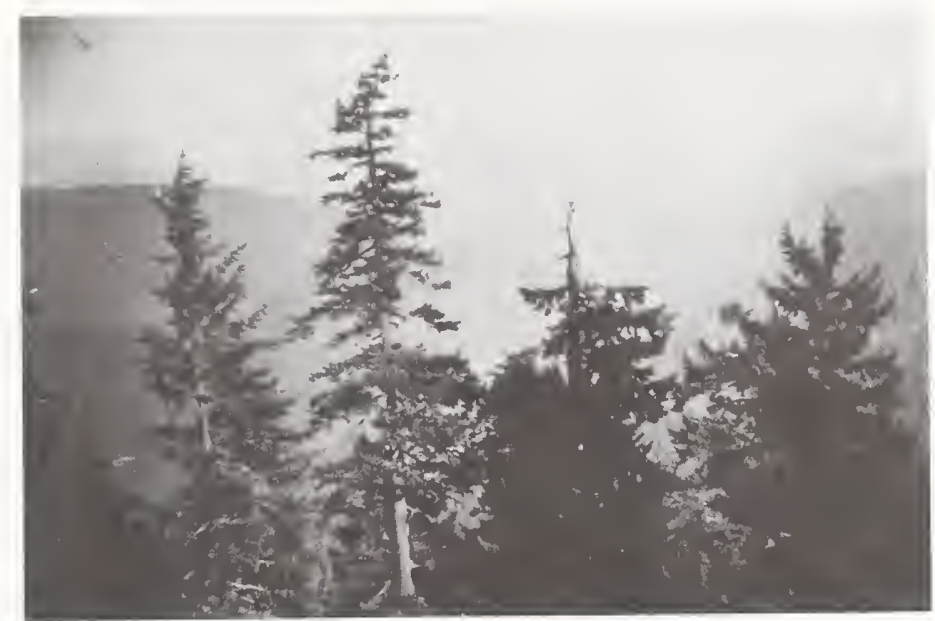

View of the Olalla Valley from the Live Oak Lookout.

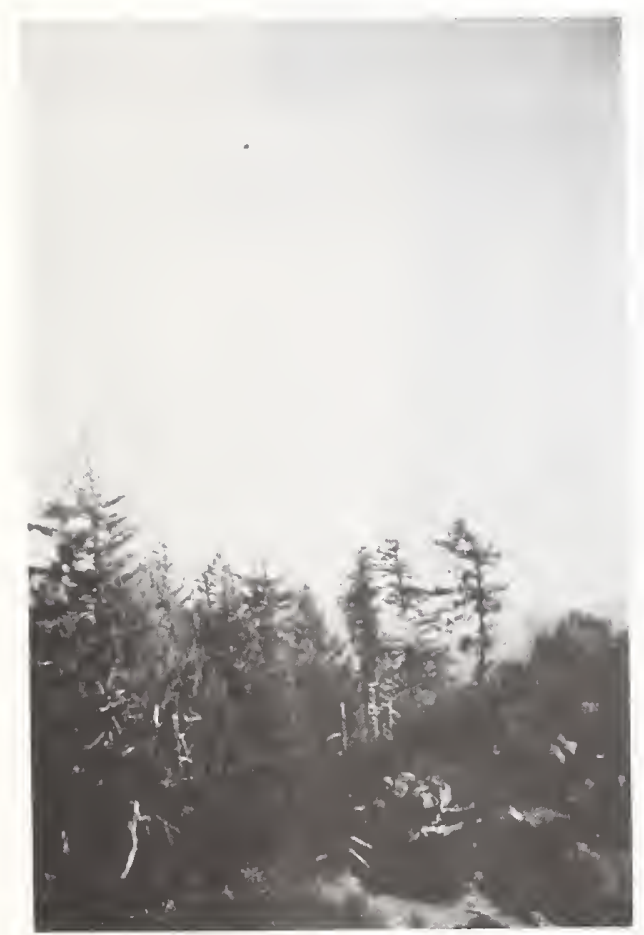

This view is from the Live Oak Lookout located about $6 \frac{1}{2}$ miles south and $2 \frac{1}{2}$ miles east from Camp Remote.

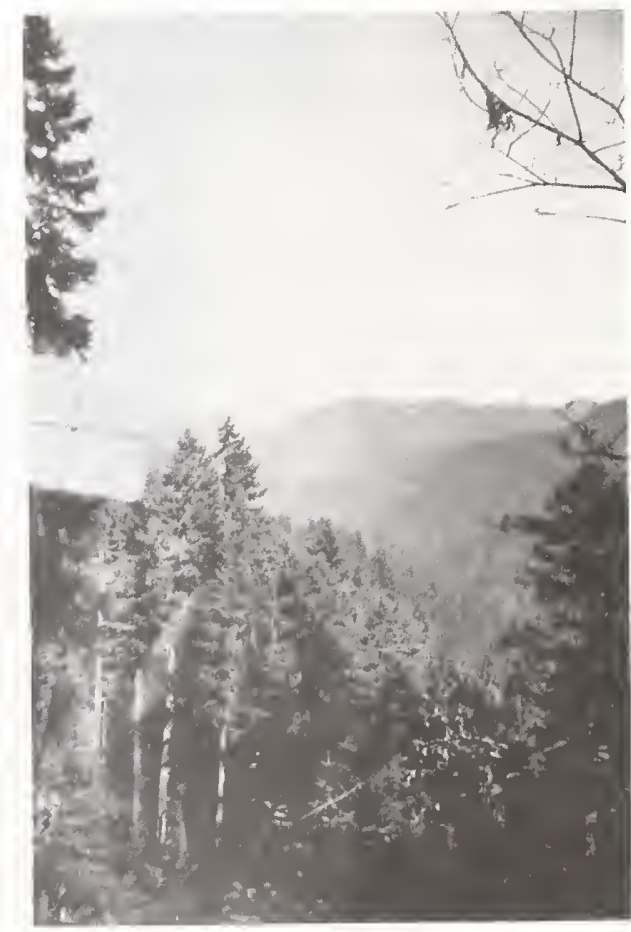

The virgin timber on the mountains surrounding Live Oak Lookout. 


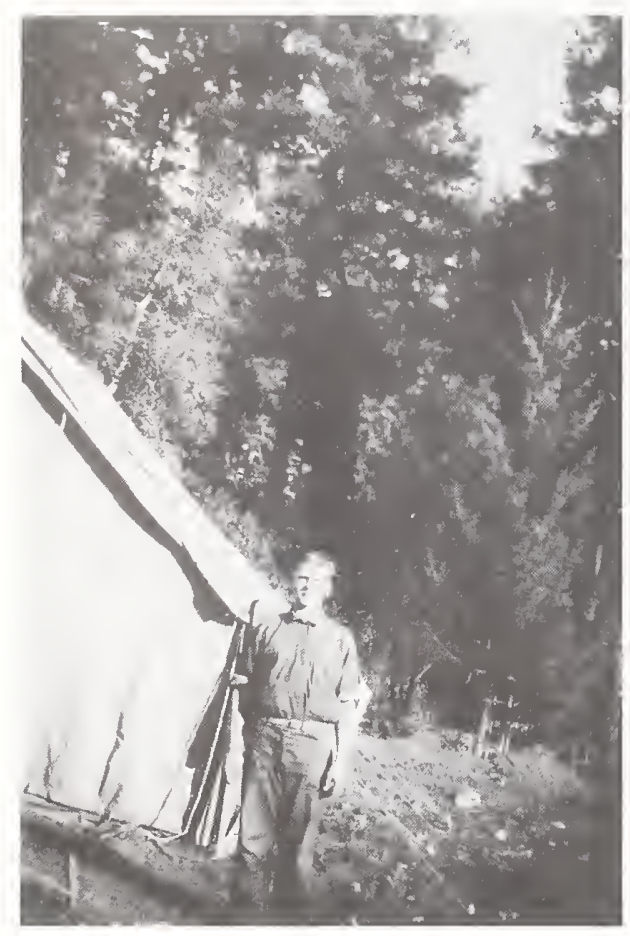

This photo was taken at the Buck Springs Side Camp where we lived in tents.

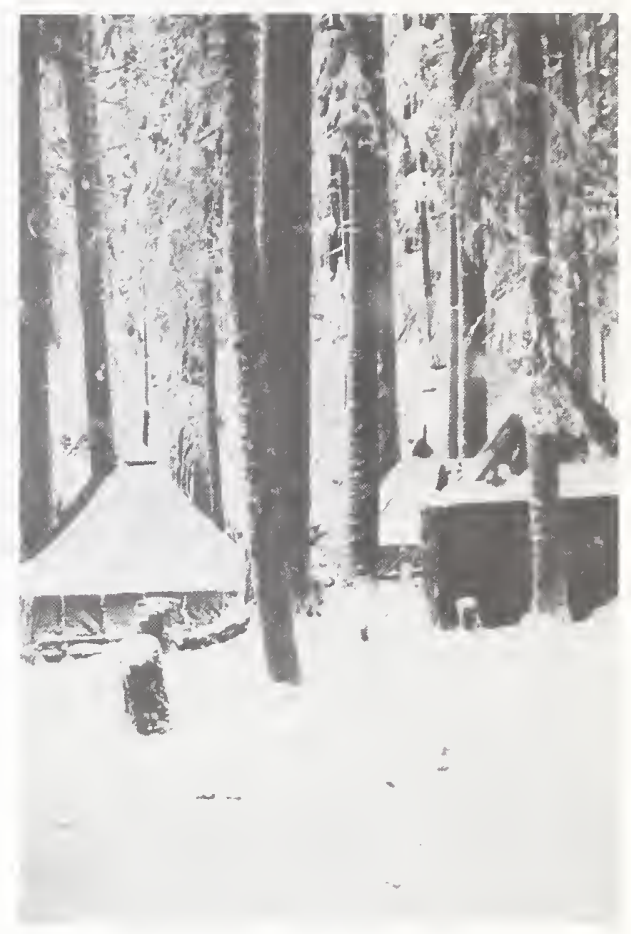

The Buck Springs Side Camp after a winter snowfall. It was while we were there that a "widow maker" fell through our tent and missed a man's head by about 2 feet.

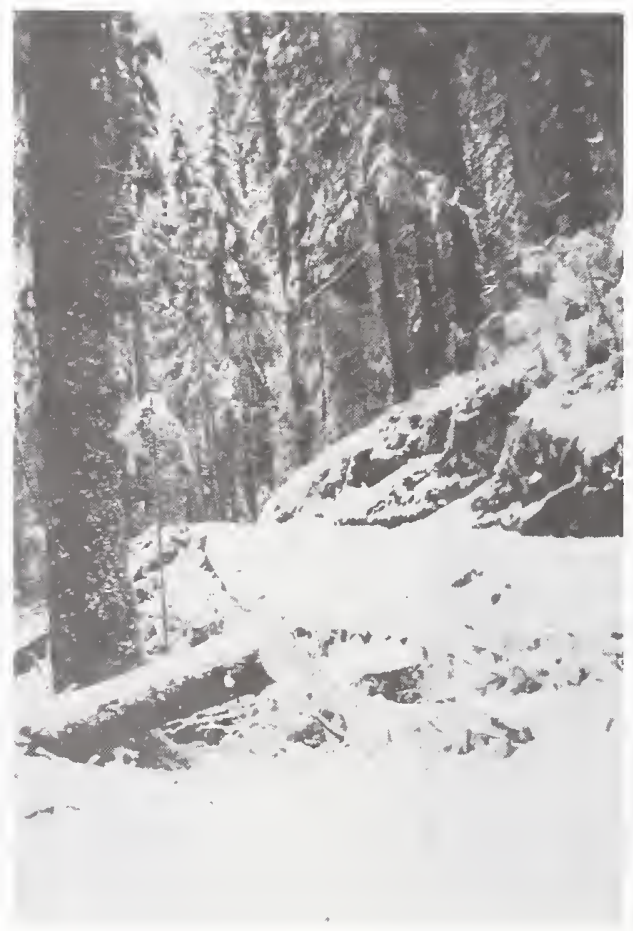

The road approaching Buck Springs Camp during that winter. The roads we constructed were not wide and allowed only a single vehicle to pass with turn outs quite close to each other for passing. 


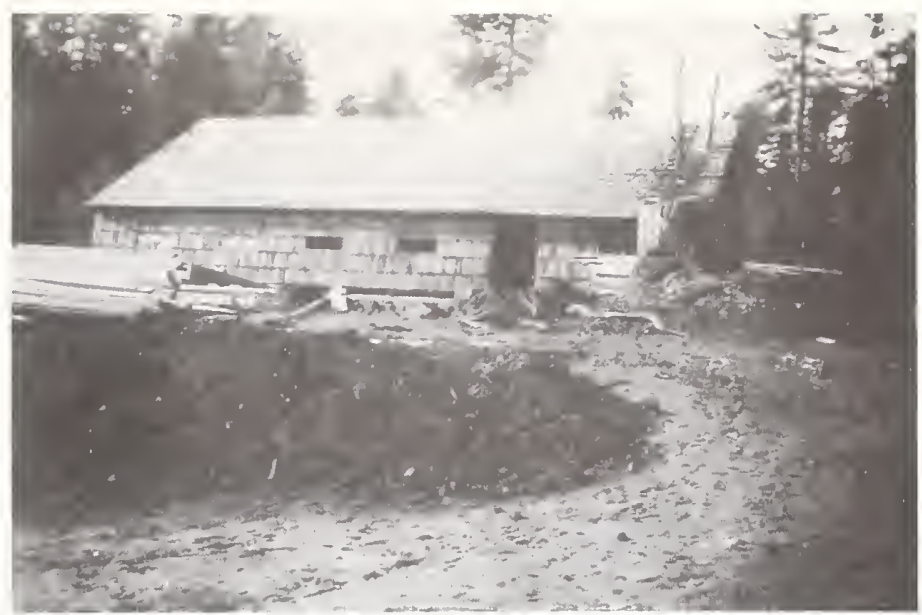

'Ihe mess hall at Camp Remote, Camas Valley, Oregon, during the latter stages of its construction at the time of our arrival.

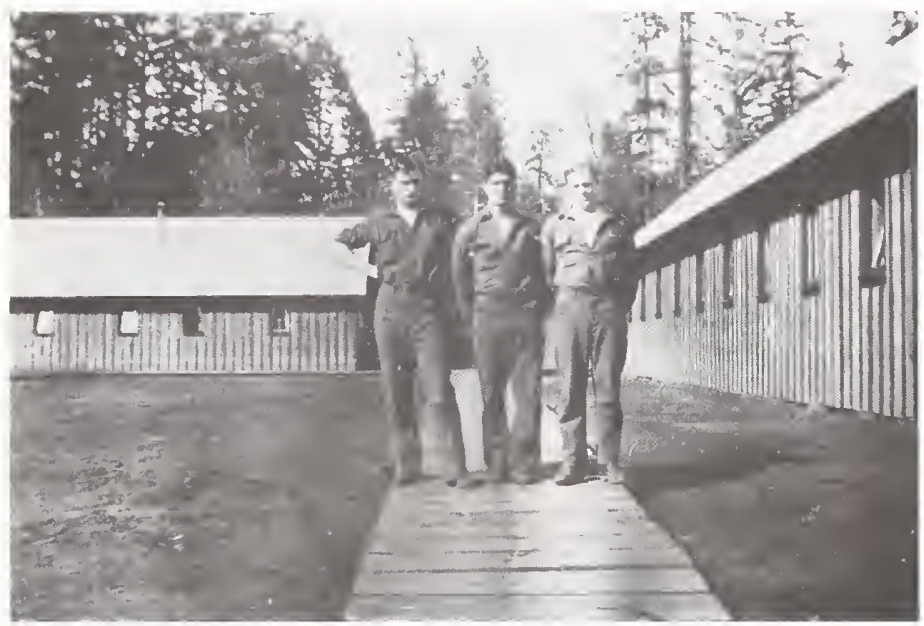

Left to right: Harry J. Kaspar, Othello V. Burr and James E. Kramer on the boardwalk beside our barracks at Camp Remote.

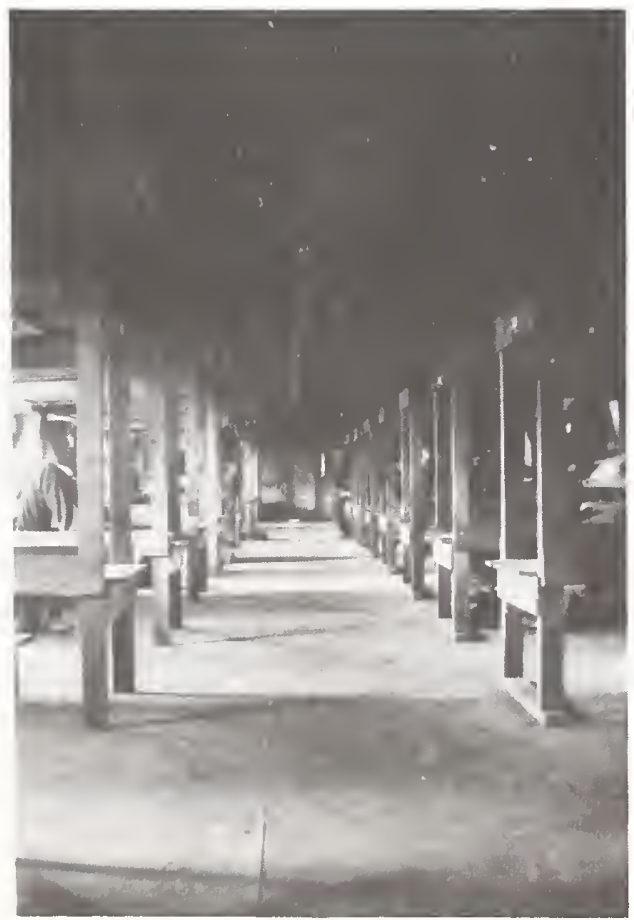

The inside of our barracks at Camp Remote. 


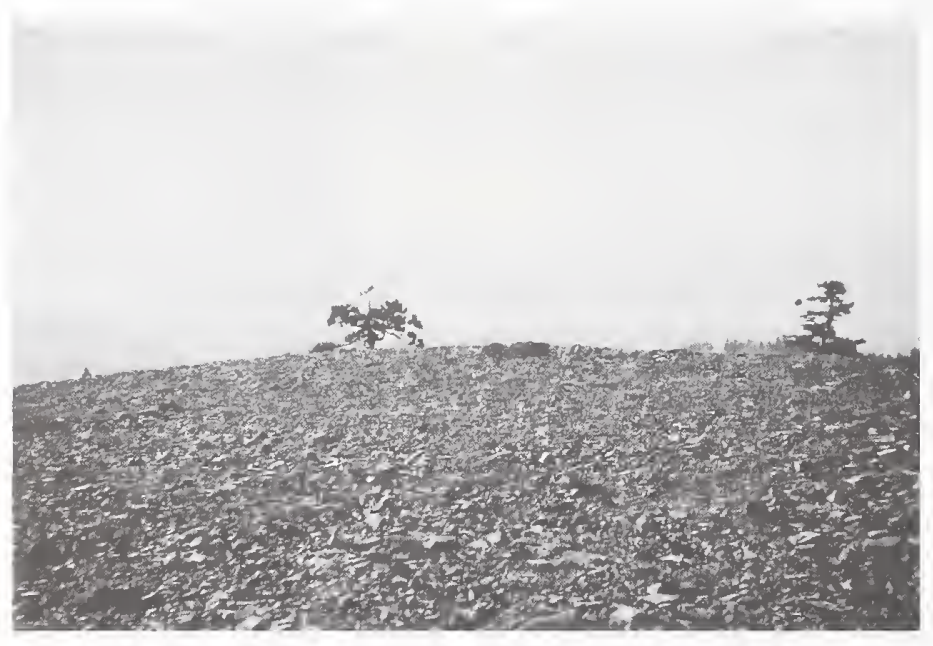

The top of Bald Ridges with a faint Mt. Pitt (McLoughlin) in the smokey distance.

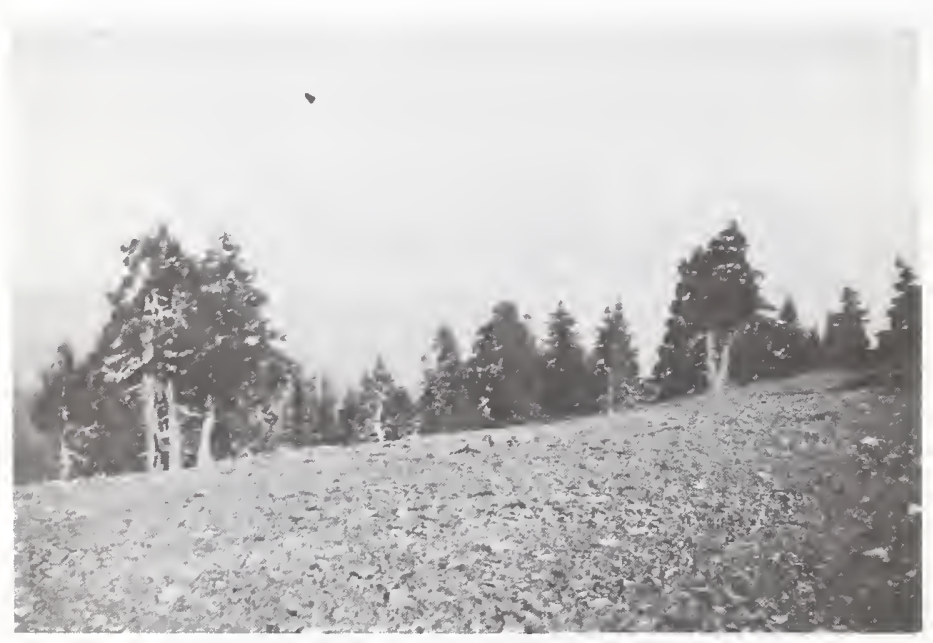

Bald Ridges showing some of the trees. 


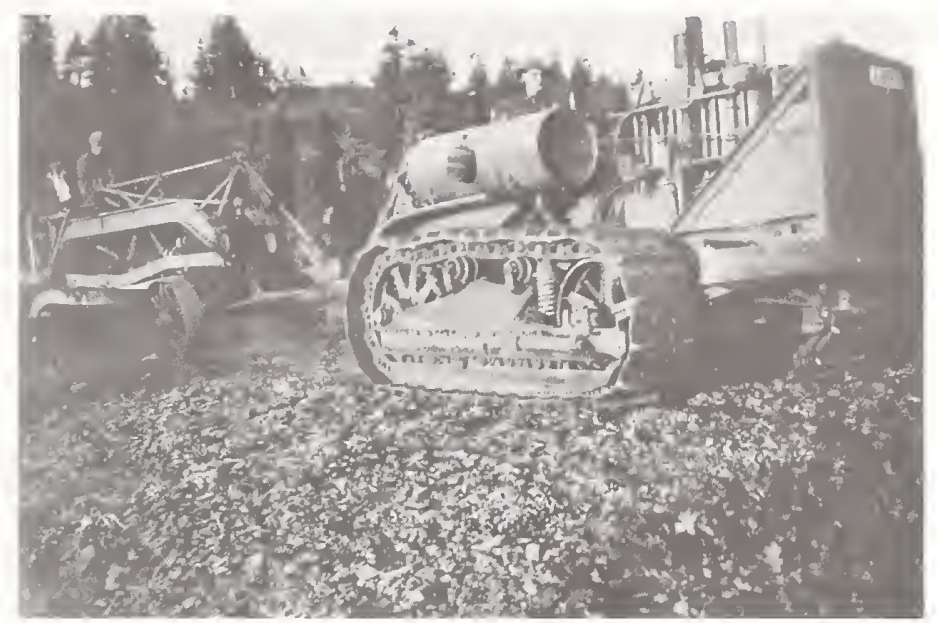

Albert Schloalman and Hank Anderson operating the caterpiller tractor and grader at Bald Ridges.

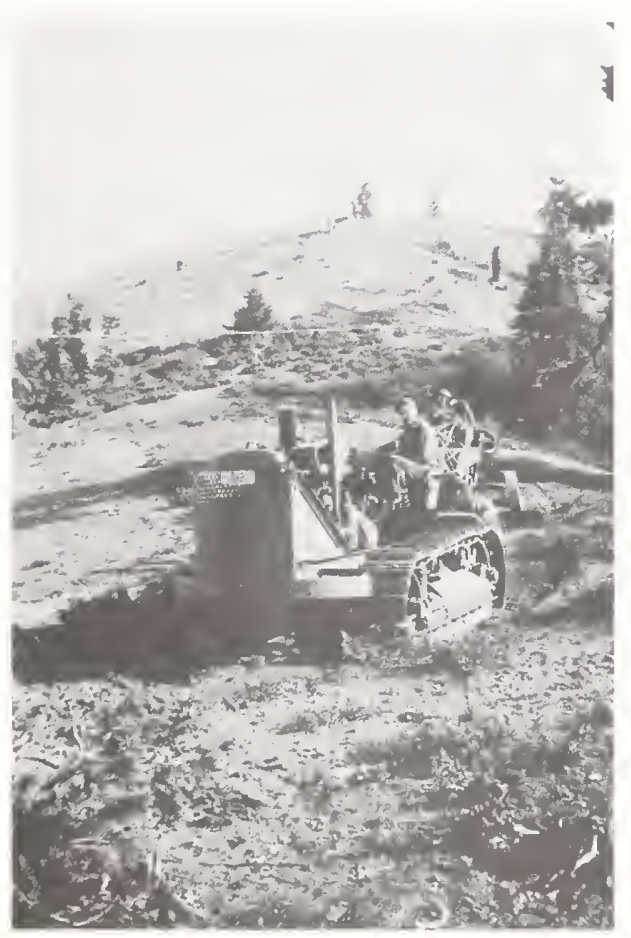

Another photograph at Bald Ridges with Schloalman and Anderson operating the road construction equipment.

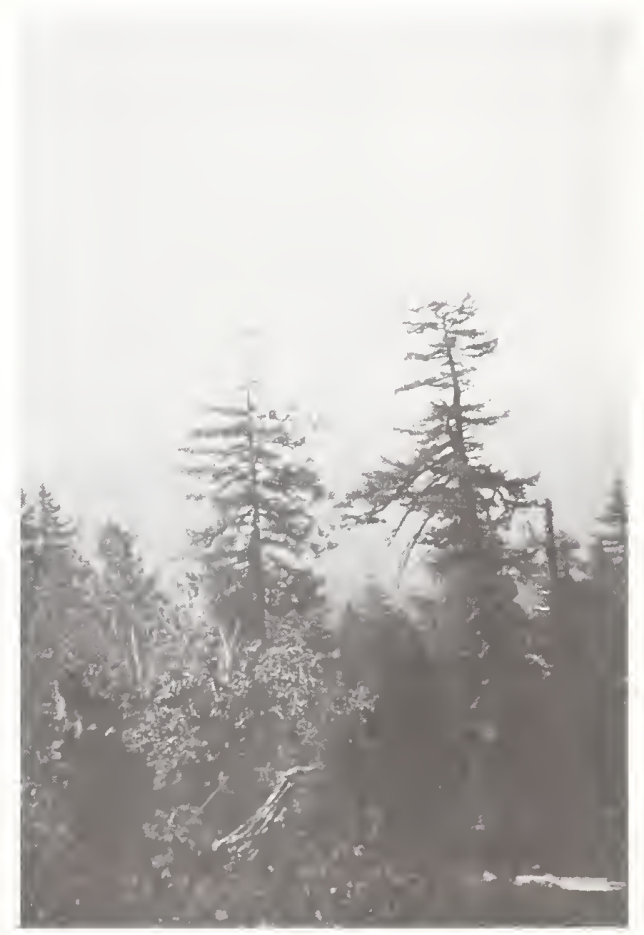

A general forest view from Butler Butte. 


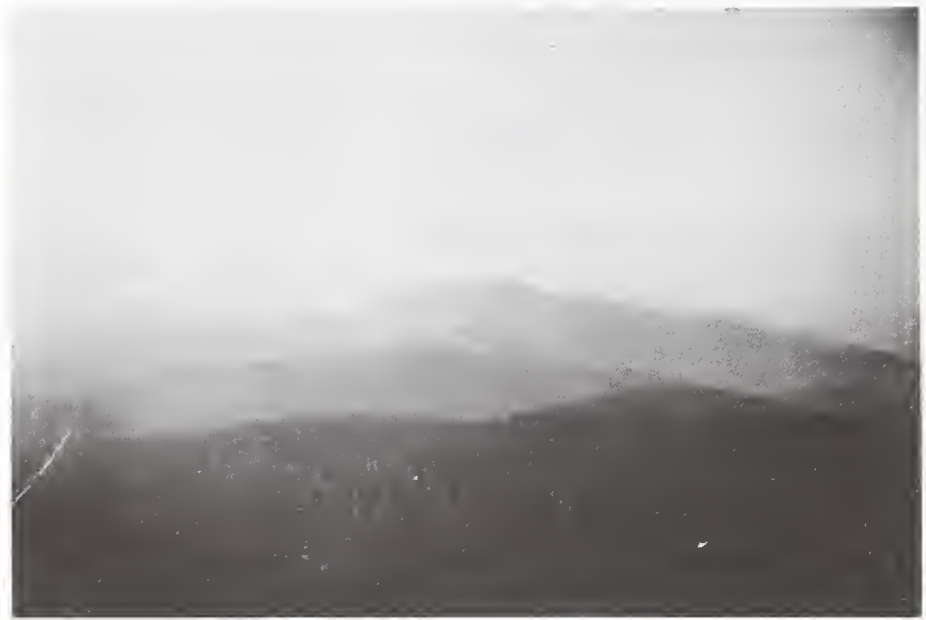

A fine view of the dense, virgin forest from Butler Butte.

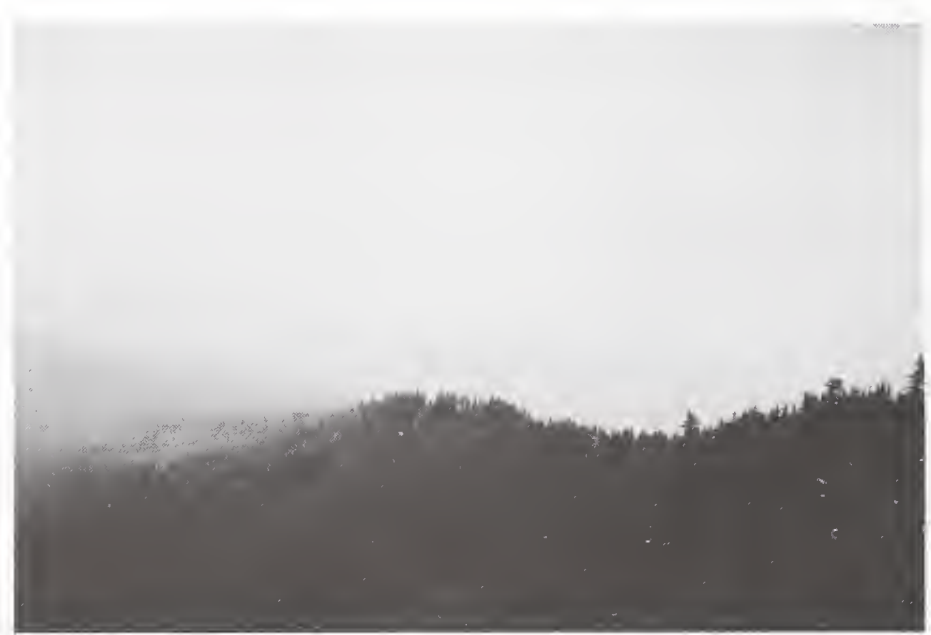

Another fine forest view from Butler Butte with smoke from the 1933 summer forest fires clouding at atmosphere. 


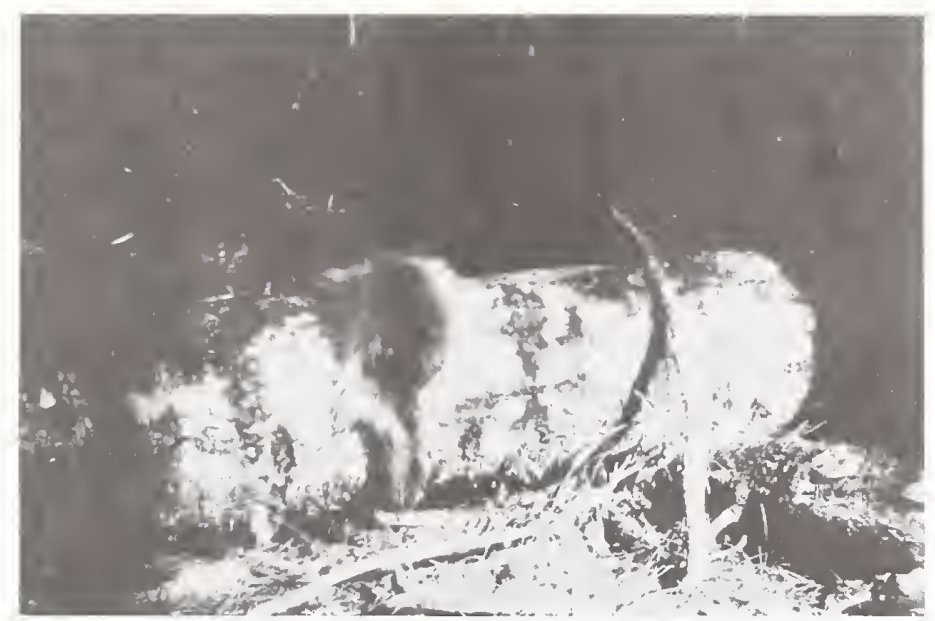

While at Buck Springs Camp we ate venison at times for meat was not received too frequently. Once we killed a porcupine and tried to eat it. It was very fat but the meat was so tough our steak knives would not touch it. This was the porcupine before we dressed it.

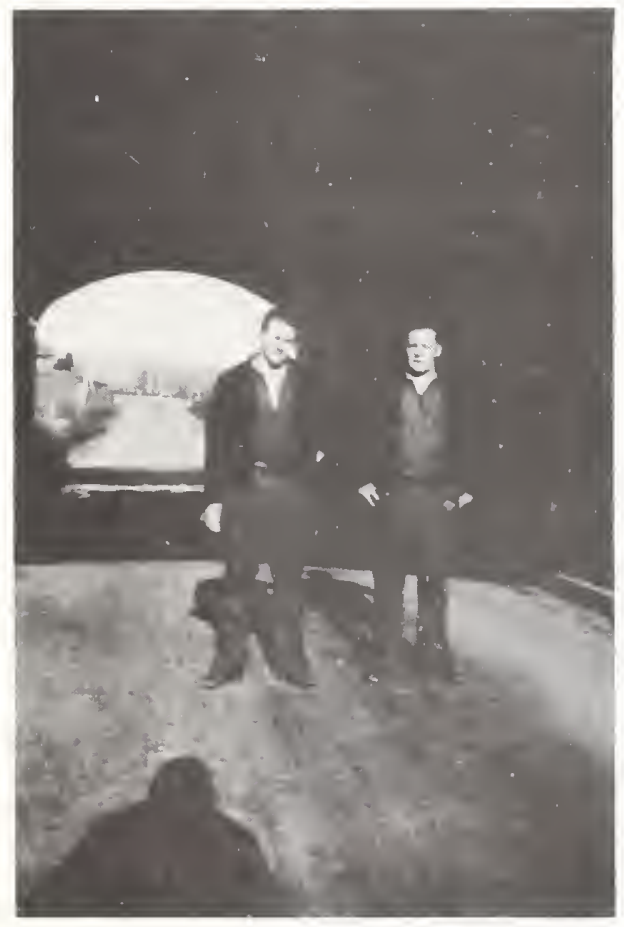

Ieft to right: Joseph A. Nielsen and James E. Kramar under a covered bridge west of Camas Valley, Oregon.

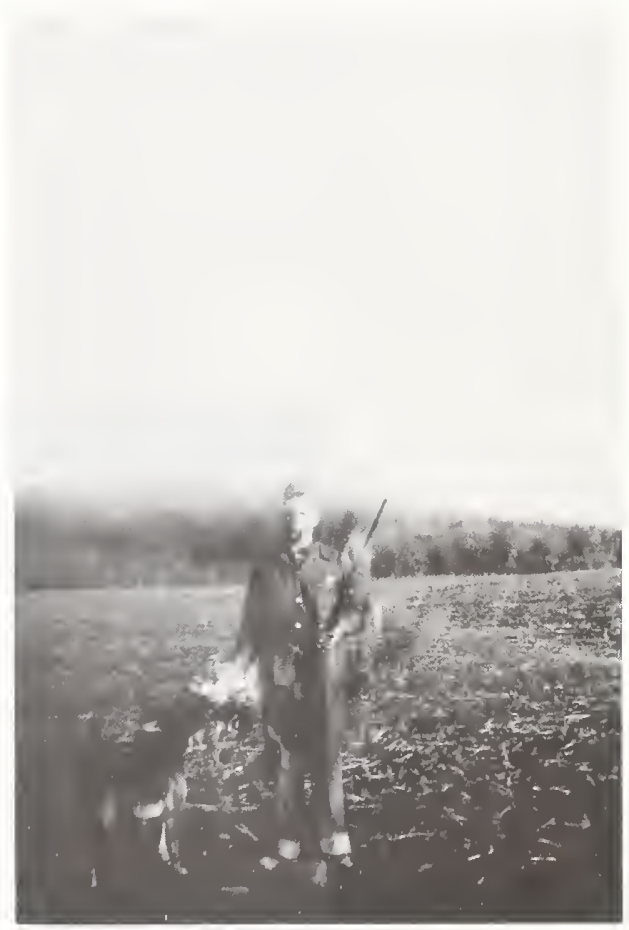

After hunting pigeons in the Camas Valley while I was at Camp Remote. 


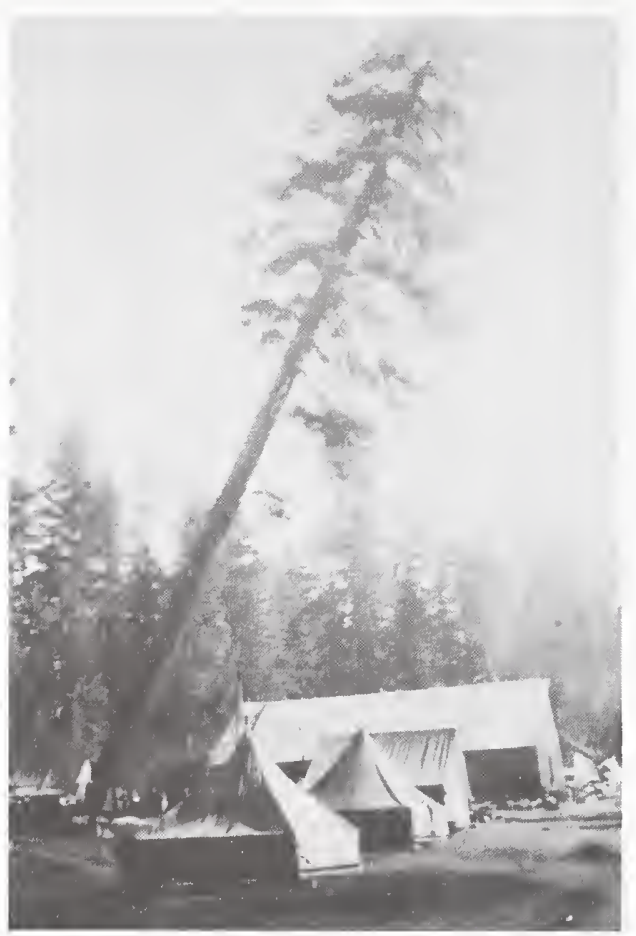

The falling of a huge sugar pine at the Camp Remote grounds.

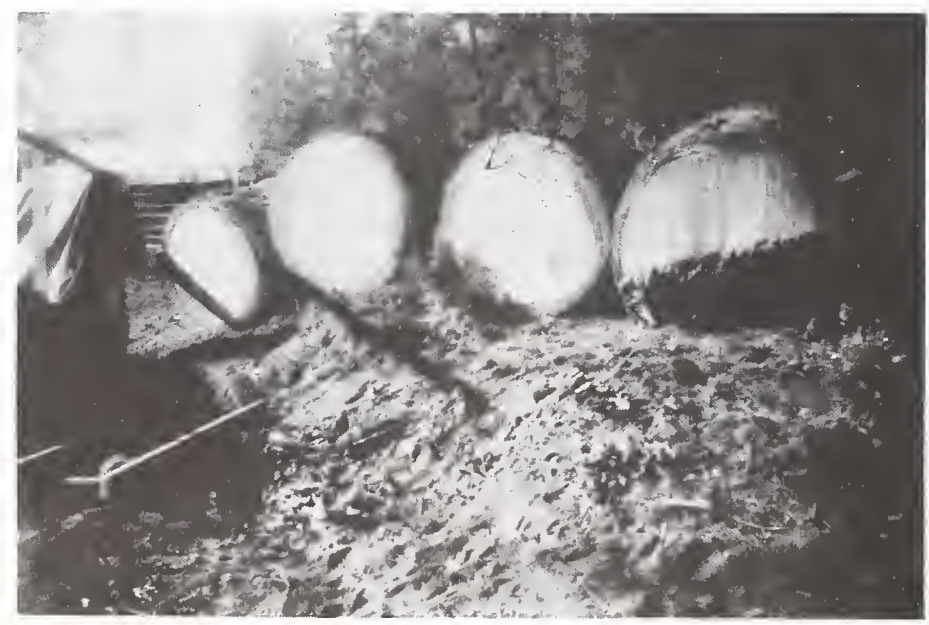

The sugar pine tree after it had been cut into logs. 


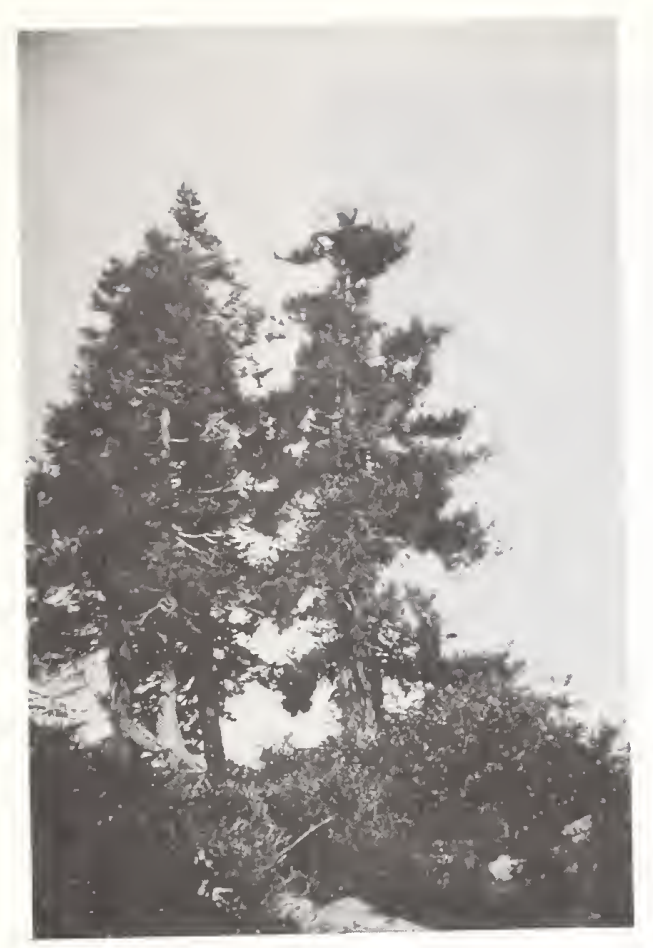

The tree lookout at Butler Butte.

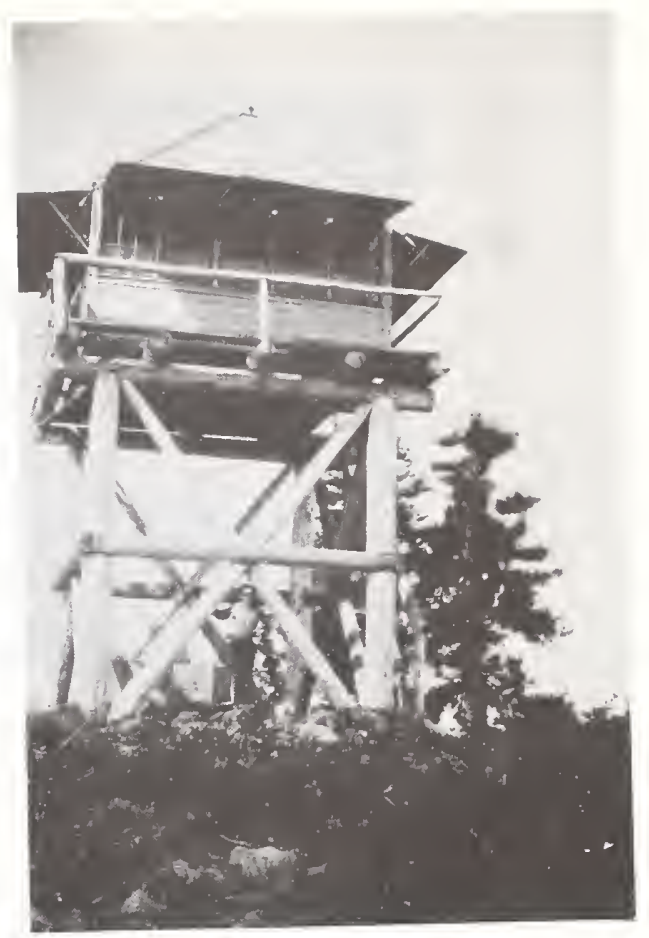

Al Barrows at the Butler Butte lookout.

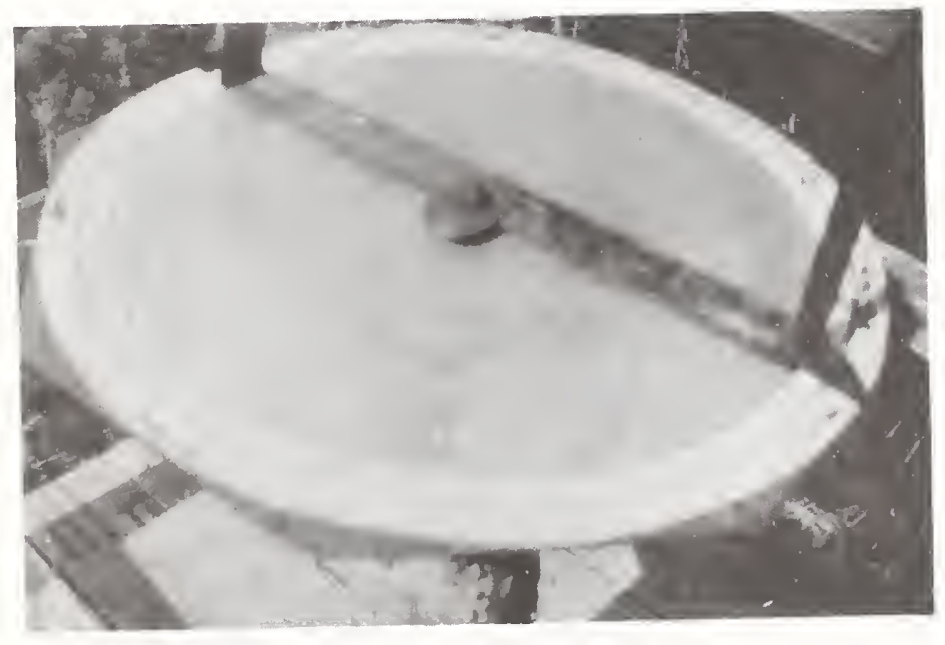

The fire finder on top of the tree lookout at Butler Butte. 


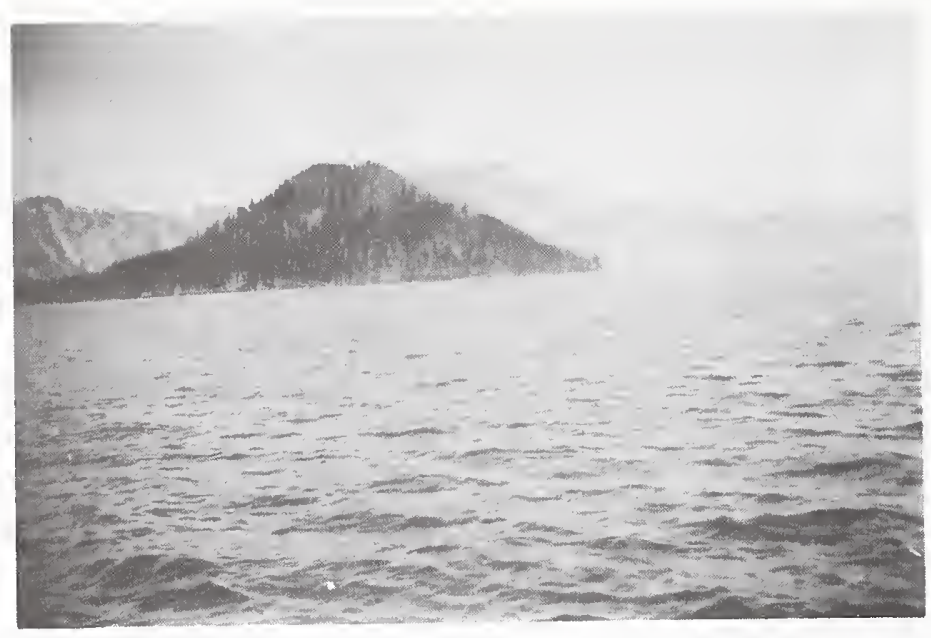

Crater Lake and Wizard Island.

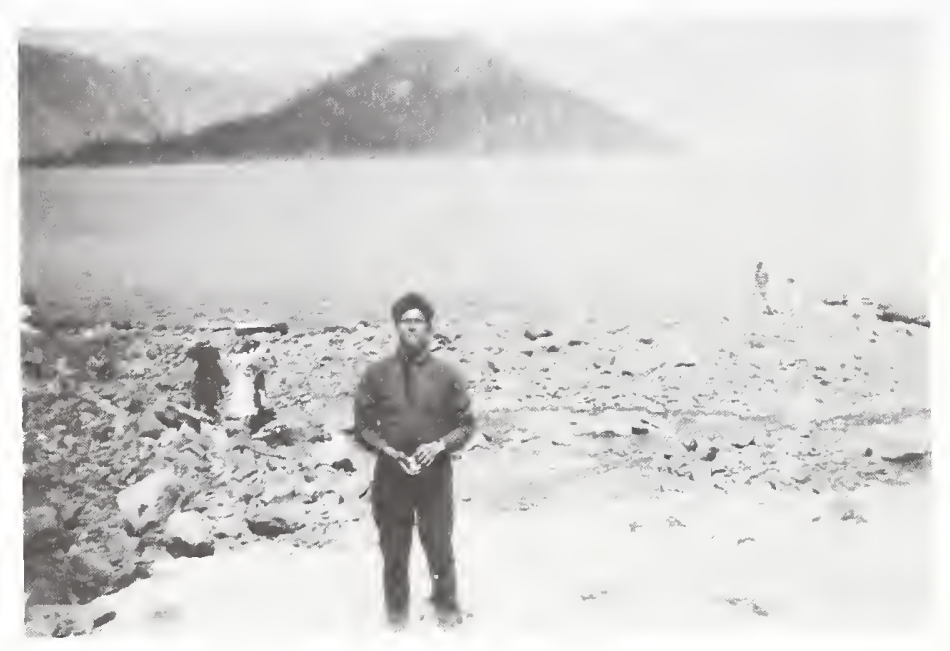

Crater Lake, Wizard Island and myself.

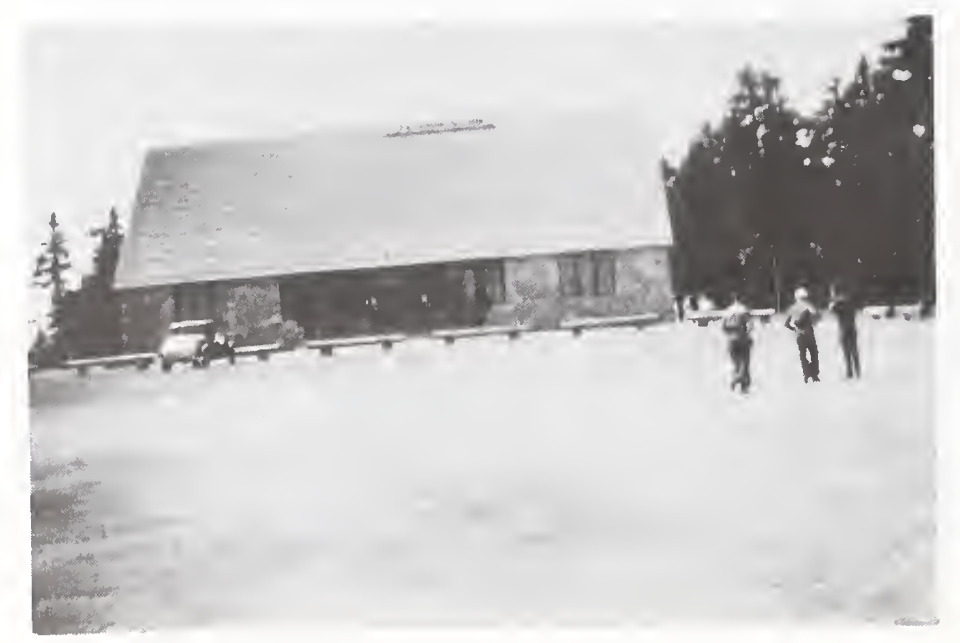

Toward the later part of the summer of 1933 each Sunday they would take a group of our CCC camp boys to Crater Lake National Park. This photo is of the day lodge. 


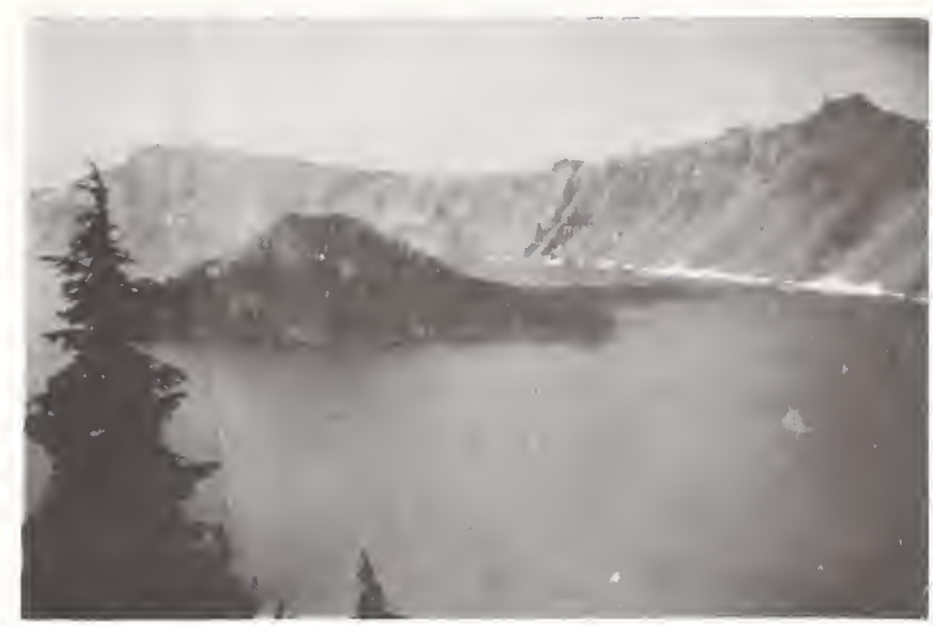

Crater Lake and Wizard Island photographed from the rim.

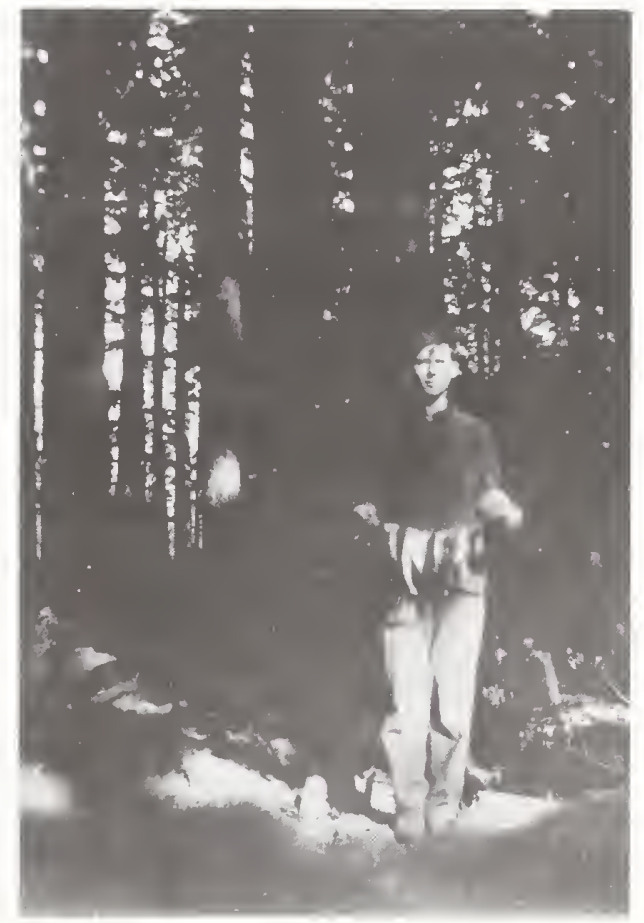

The results of one of my fishing trips to Beaver Creek. During the entire summer I failed to see a man's track or a person on this creek. And the biggest fish there would alwasy spook when I cast into this pool. But I could get the smaller fish in that same pool. 


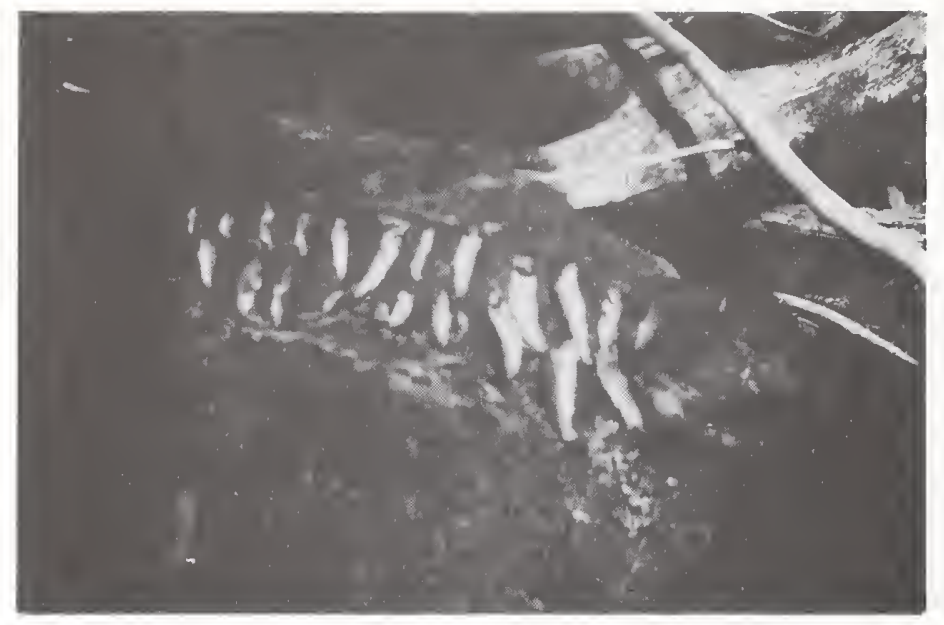

A string of trout that I caught in the upper reaches of Beaver Creek. The Beaver Creek canyon was between 1 and 2 miles from Fawn Canp. The sugar pine forest in the very upper part of Beaver creek was remembered as park-like and beautiful. I wonder if it is still there?

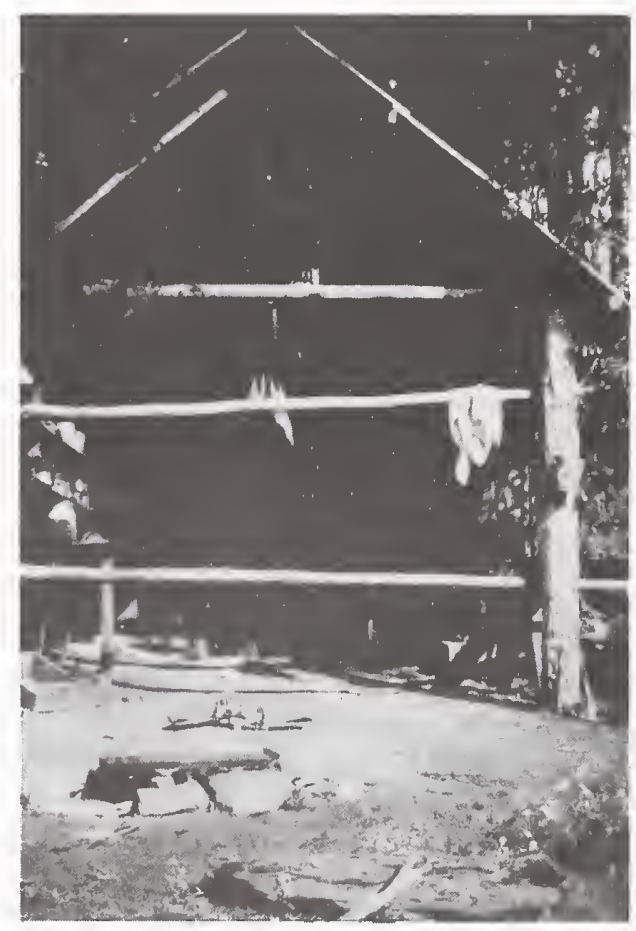

A trapper's cabin and a bear trap near Fawn Creek. 


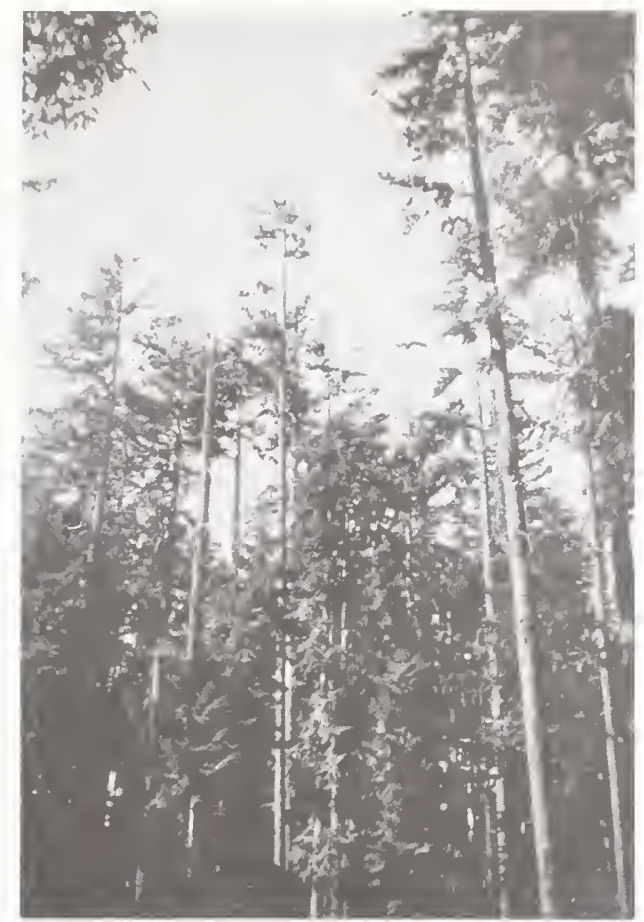

Olie Lynch topping a tall fir tree adjacent to Fawn Carm.

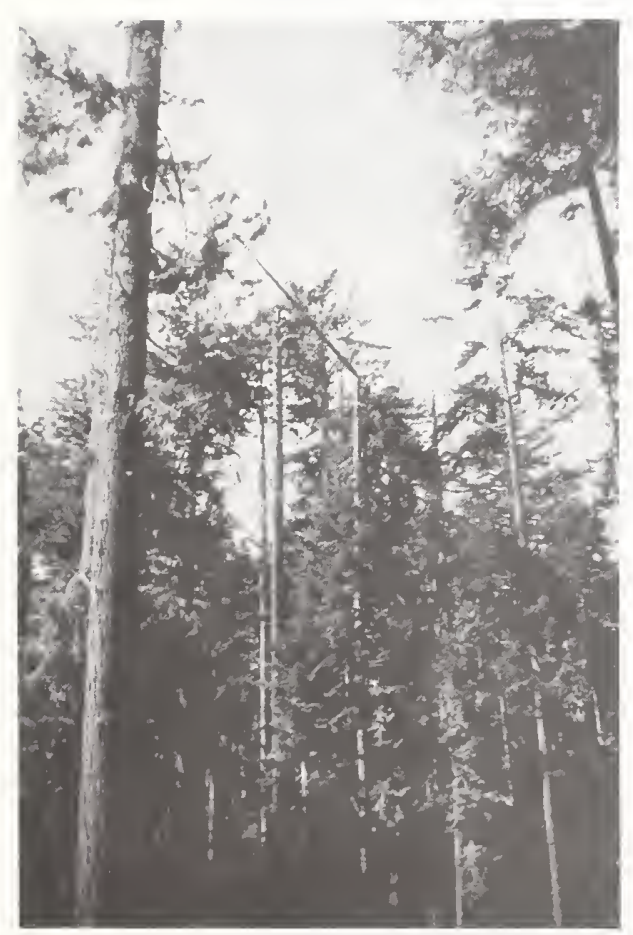

The top of the fir tree breaking awa after being cut by Olie Lync. There was no reason to top this tree except Lynch wanted to show us that he could do it. This is somewhat like climbing a mountain because it is there.

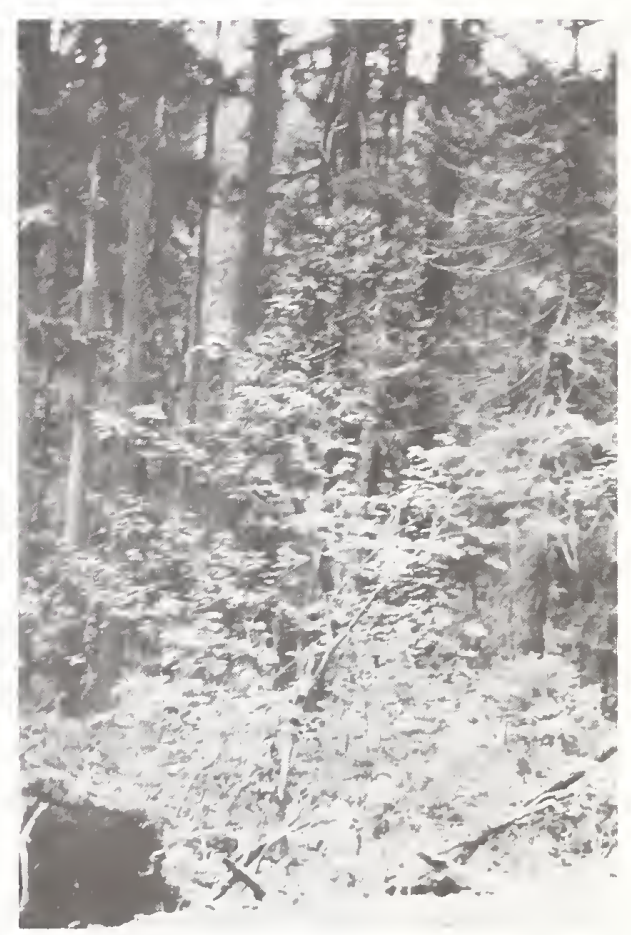

This dense growth was between Fawn Carp and Beaver Creek. When one hiked a short distance more toward Beaver Creek, the virgin forest became much more open. 


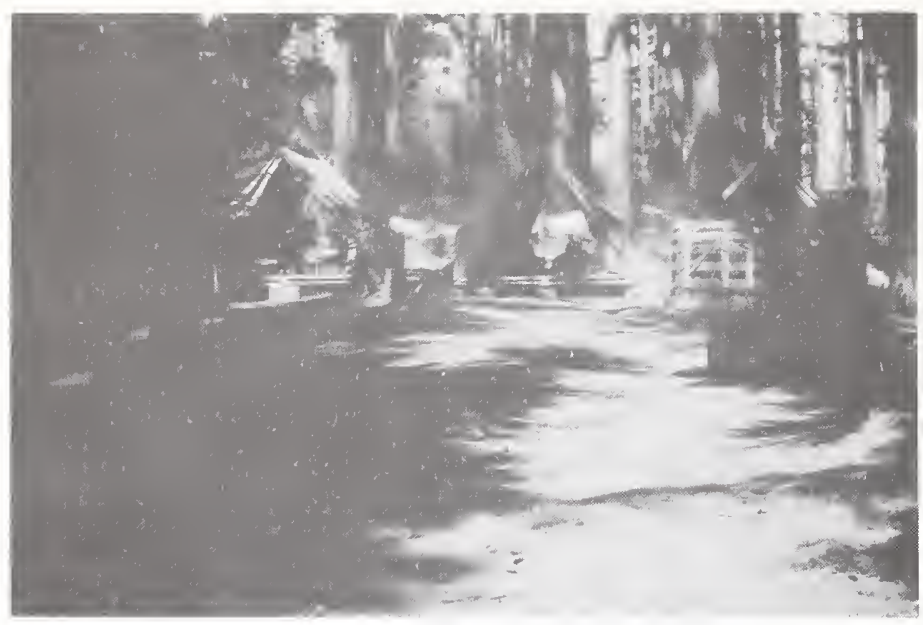

Fawn Camp was within a dense, virgin forest.

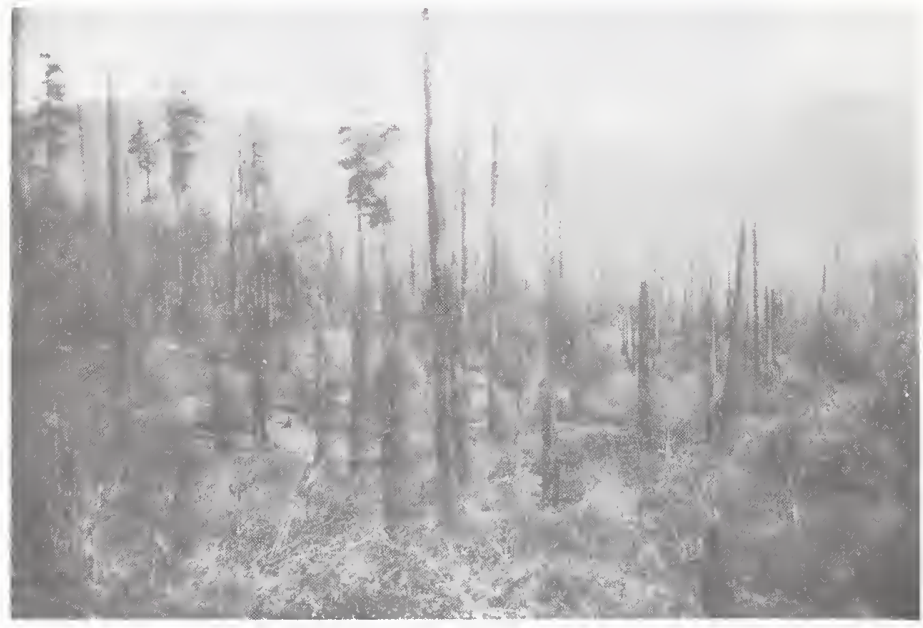

The Fawn Camp burn was from some prior year as underbrush had substantial growth. This was in the Fawn Creek basin but near Fawn Camp.

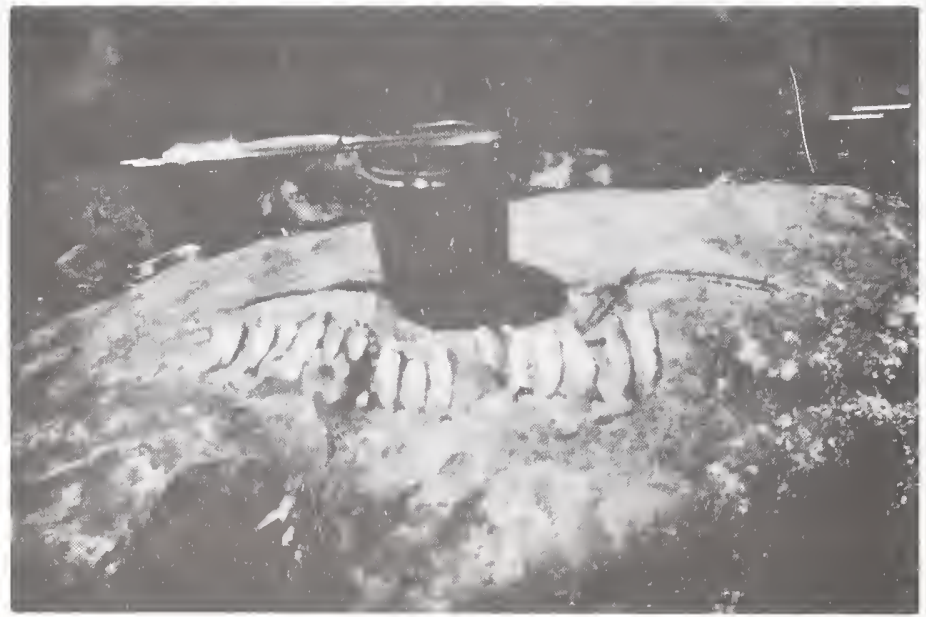

The book trout I caught in Drew Creek were very small but excellent eating. Elk Creek seemed to be chiefly devoid of fish. This is the final photograph from the Carmp Drew area. 


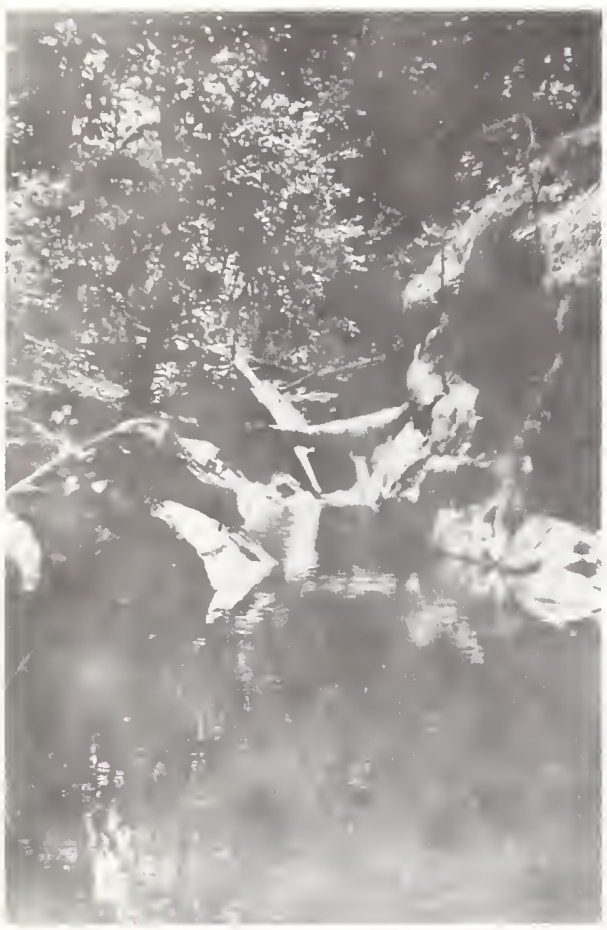

This is the Tiller-Trail Road up Elk Creek that passed Camp Drew and then the hamlet of Drew, Oregon.

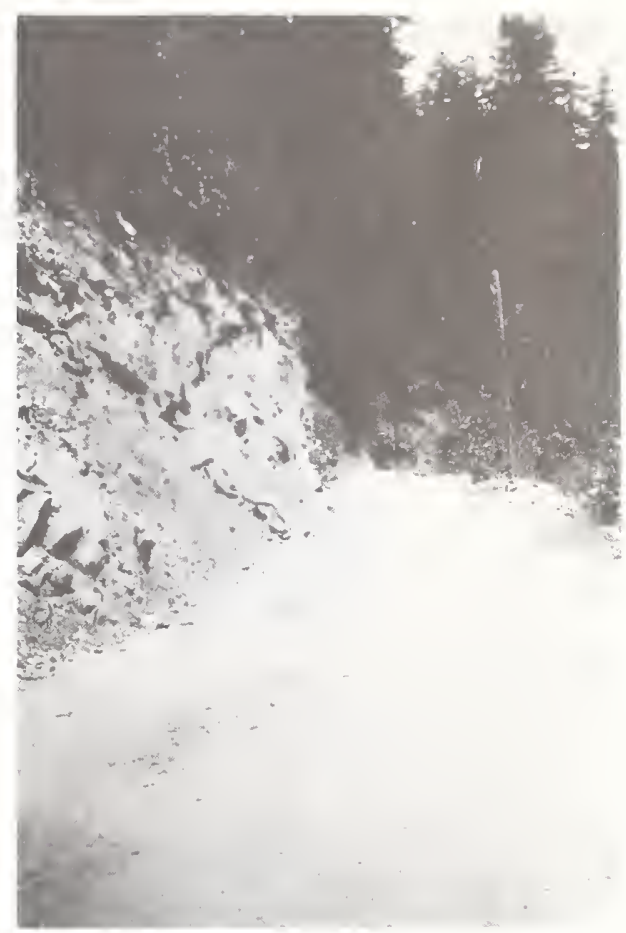

Elk Creek just above Canp Drew. Due to the canyon and the heavy growth of trees, it was quite dark for my camera, an ordinary box.

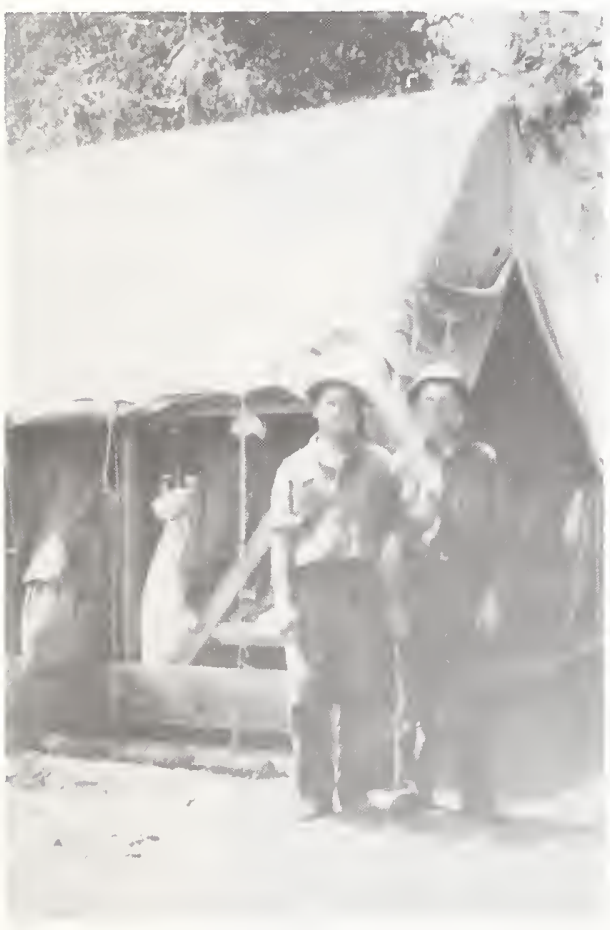

The unfinished mess hall at Camp Drew.

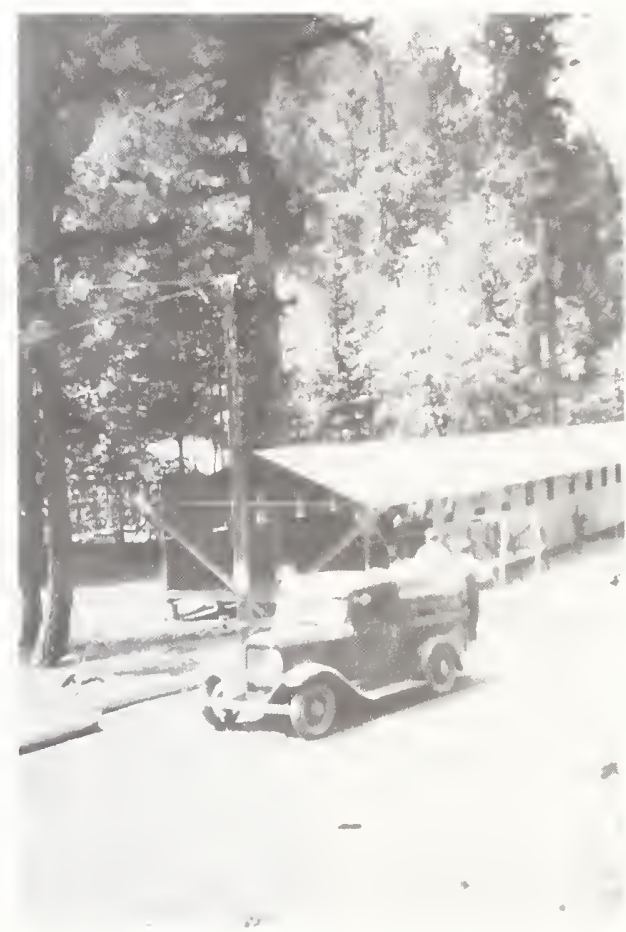

Nickolas L. Laudenklos and Norman A. Myers in front of our tent at Canrp Drew. 


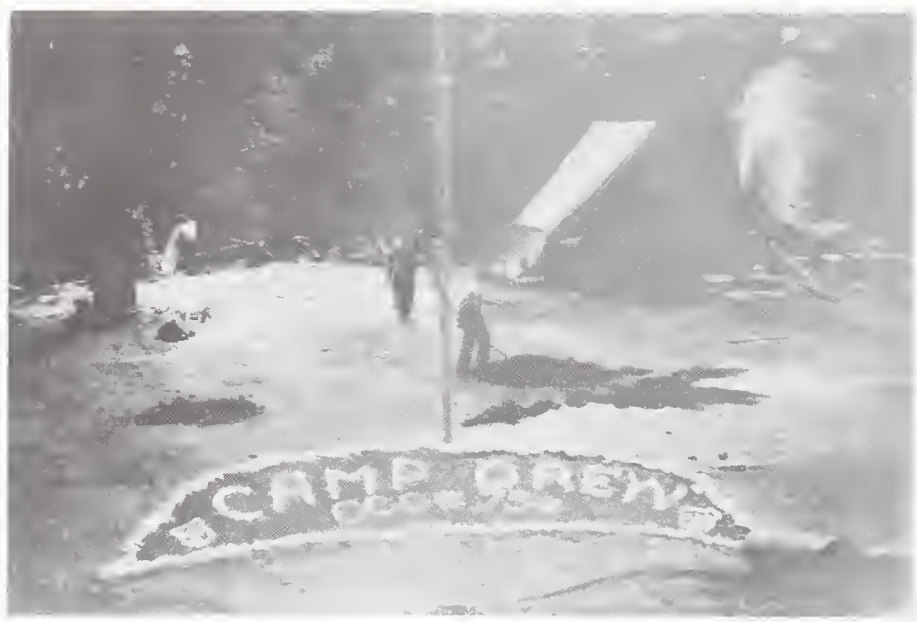

The Camp Drew flag pole and the camp's identification This was just after we arrived.

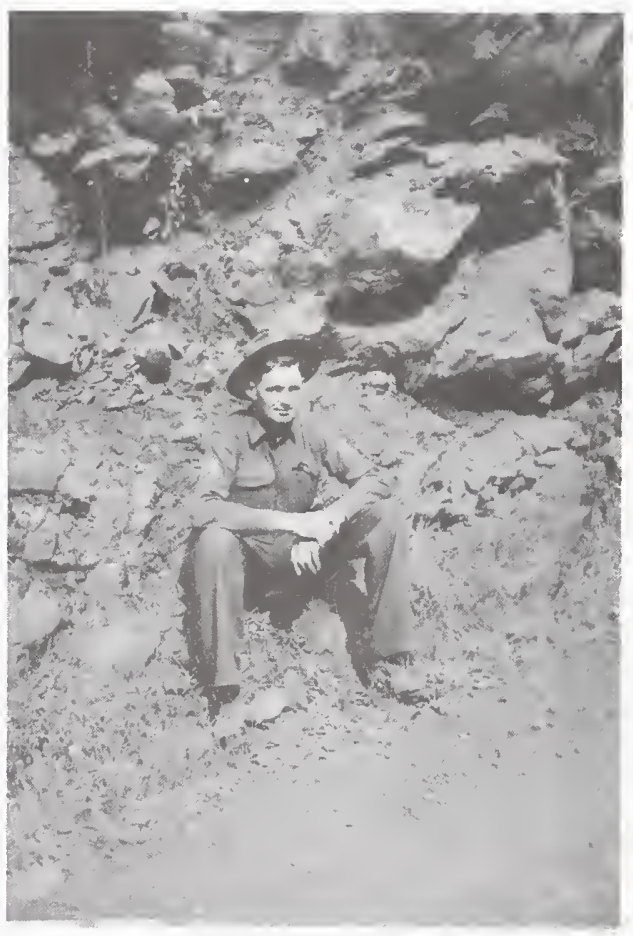

Our U.S. Army Sergeant John Teebken at Camp Drew 


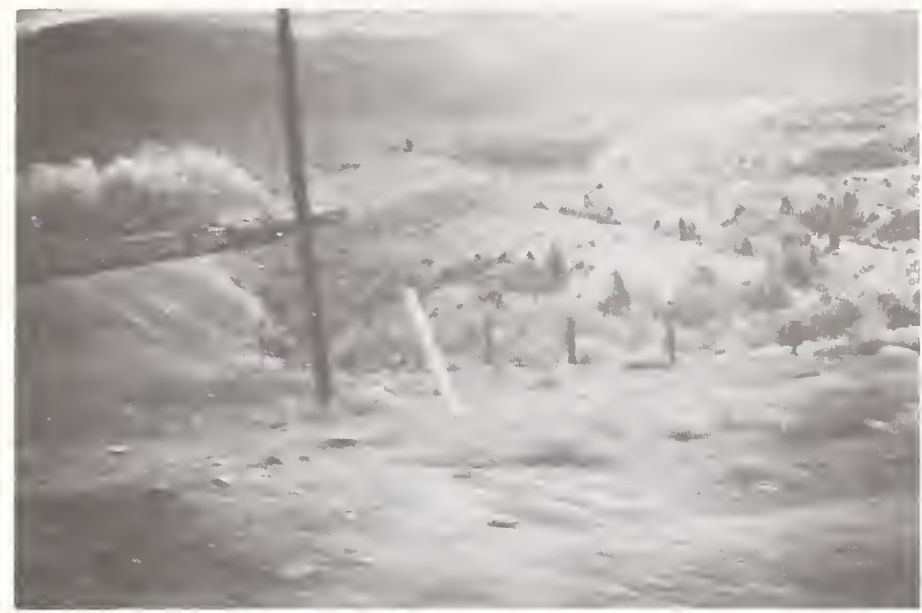

A doubleheader pulling our CCC special train u Soldier Sumitt, Utah.

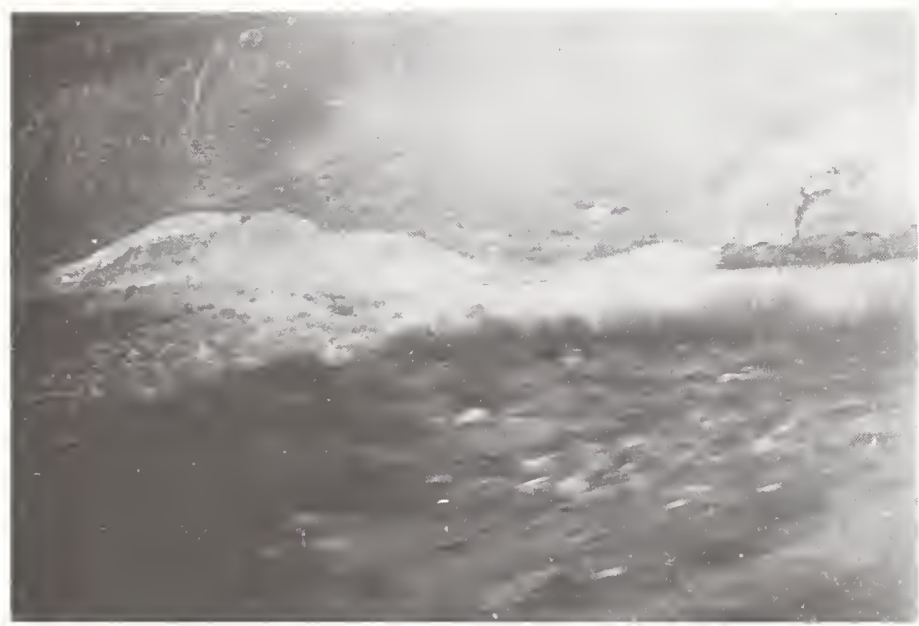

The front end of our train while working its way up to Soldier Sumit, Utah.

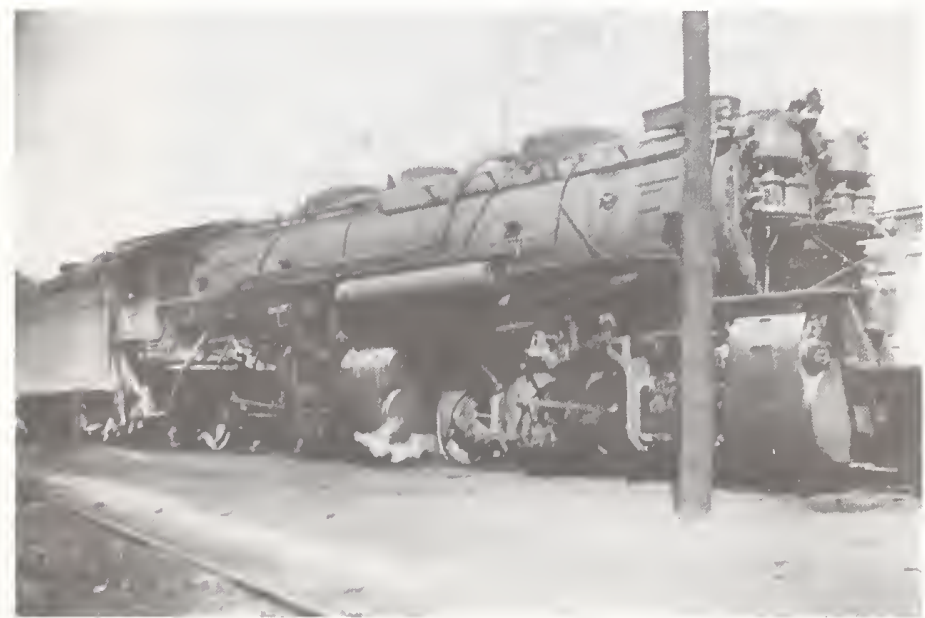

A large Denver and Rio Grande Western RR locomotive that pulled our train through Thistle, Utah. 


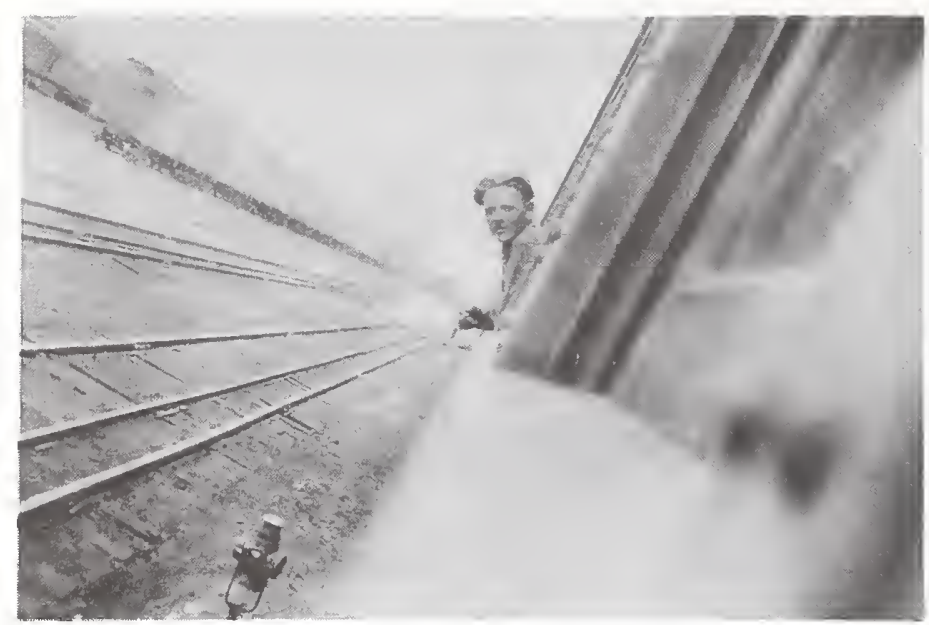

Eric Simett looking back from railroad car window at Salida, Colorado on June 13, 1933.

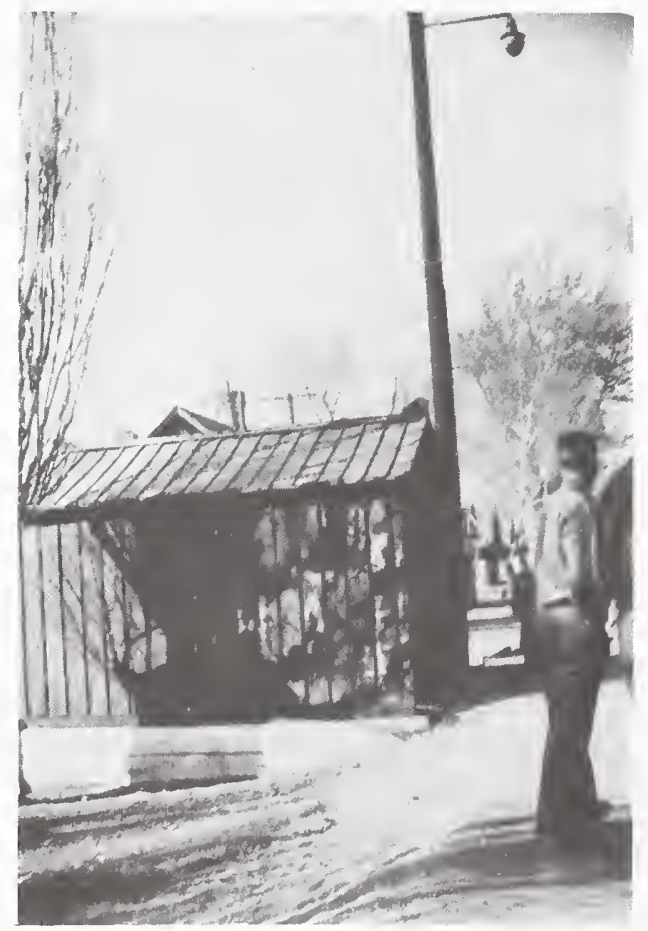

Picture of rock taken at Helper, Utah, while our train was serviced. 


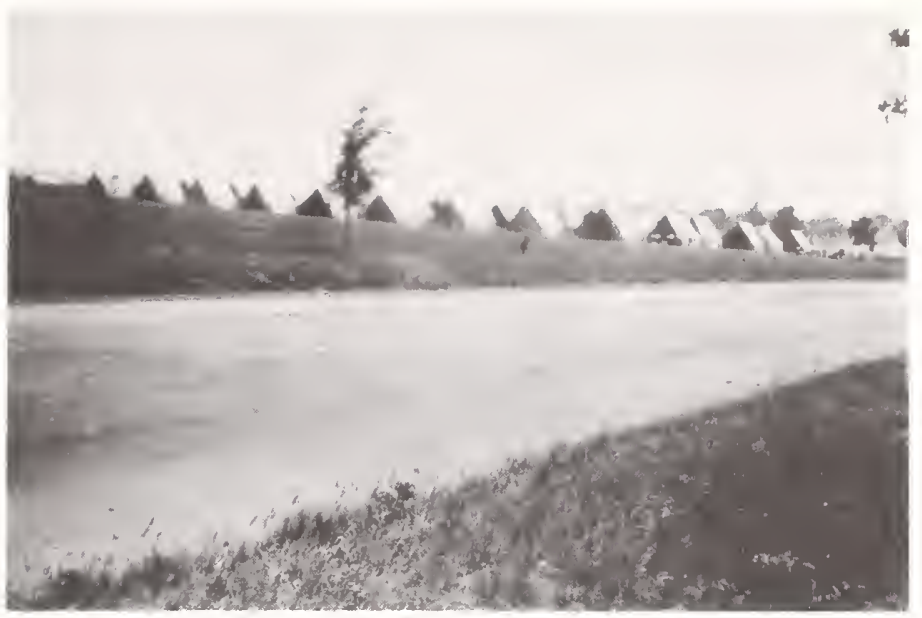

The original canm at Fort Crook, now Offutt Air Force Base.

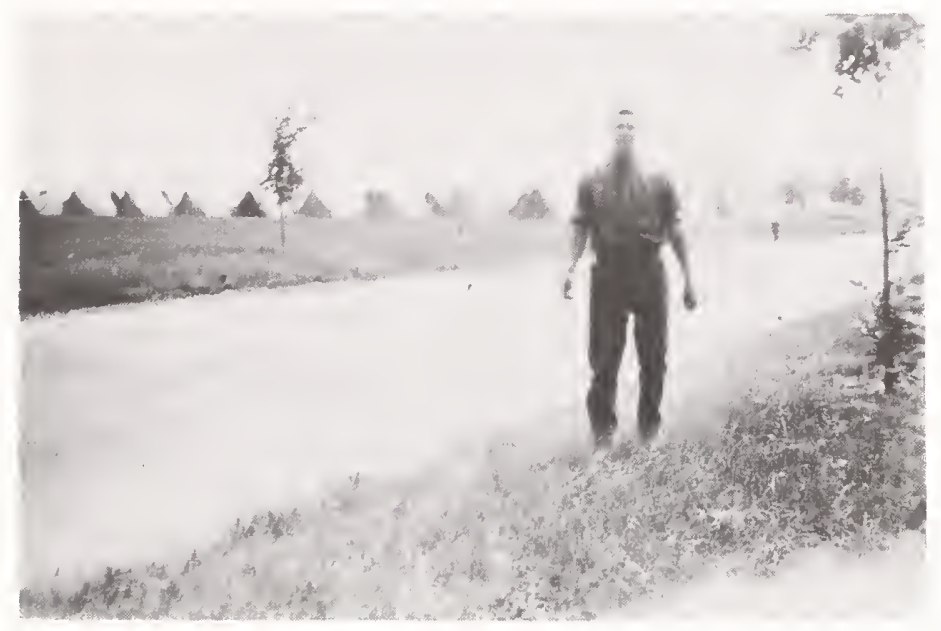

Norman A. Myers at Fort Crook with our tents in the background. 


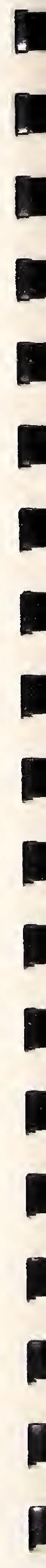



NATIONAL AGRICULTURAL LIBAARY 